\title{
DERECHO A LA CIUDAD
}

HACIA UNA CONSTRUCCIÓN METODOLÓGICA PARA SU EVALUACIÓN 


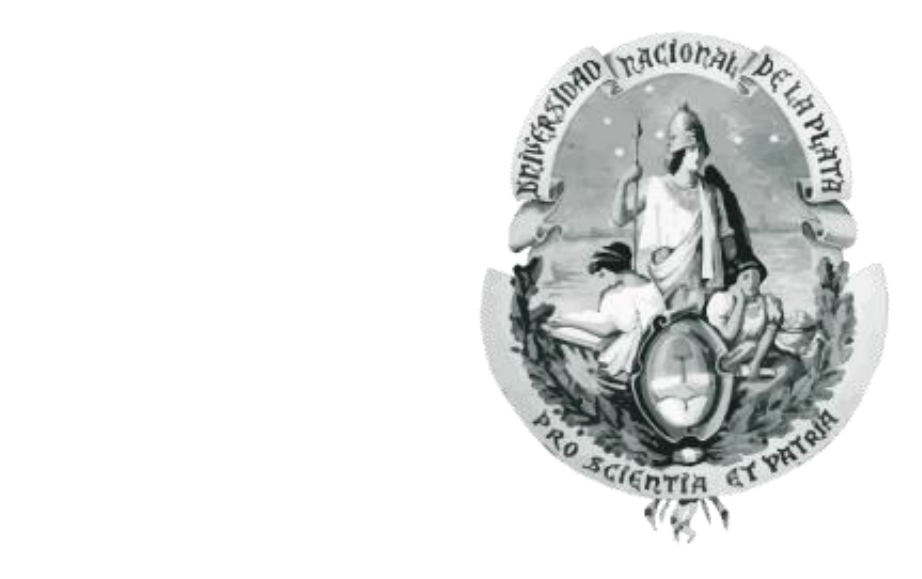

Universidad Nacional de La Plata Facultad de Arquitectura y Urbanismo

Maestría en Ciencias del Territorio

Tesista Arq. Estefanía Jáuregui

\author{
Director \\ Dr. Arq. Juan C. Etulain
}

Co-Director

Esp. Arq. Miguel A. Seimandi 
"La cuestión de qué tipo de ciudad queremos no puede divorciarse de la cuestión de qué tipo de personas queremos ser, qué tipo de relaciones sociales buscamos, qué relaciones con la naturaleza mantenemos, qué estilo de vida deseamos o qué valores estéticos tenemos" 


\section{AGRADECIMIENTOS}

La tesis que aquí se presenta significa la culminación de un largo proceso de aprendizaje y esfuerzo, motivo por el cual deseo agradecer a todos aquellos que colaboraron y permitieron su desarrollo.

En principio, a la Universidad Nacional de La Plata por su apoyo a la educación pública y la investigación, así como a cada uno de los docentes que contribuyeron a mi formación como estudiante y como docente investigadora.

A mis directores, por sus correcciones y acompañamiento en este camino que significó el desarrollo de una tesis, y a todos aquellos que participaron directa o indirectamente en la elaboración de la misma.

A mis amigos, especialmente a aquellos que comparten este entusiasmo por el territorio, que me mostraron que, pese a que este desafío es personal, siempre es mejor compartirlo, engrandeciendo no sólo el trabajo sino a mi persona.

A mis padres. A mi papá, a quien recuerdo cada día, que me enseñó el valor del esfuerzo y la responsabilidad, siempre con alegría. A mi mamá, la mujer con más fortaleza que tengo la dicha de conocer, que me enseña día a día que, pese a que el camino sea difícil, se puede seguir adelante y obtener grandes satisfacciones.

A mis hermanos, tan iguales y distintos a la vez, que me muestran que el soporte de la familia es incondicional y fundamental para dar cada paso en la vida. A ellos, gracias por impulsarme a continuar.

A mi compañero Gabino, por su cariño y compañía en este camino, sinuoso y con dificultades, siempre desde el amor, porque este recorrido no hubiera sido el mismo sin su apoyo y comprensión.

A mi familia toda, por sus consejos y sus valores, mi mayor agradecimiento.

A todos ellos, gracias. 


\section{RESUMEN TÉCNICO}

El enfoque del derecho a la ciudad, entendido como el usufructo equitativo de las ciudades dentro de los principios de sustentabilidad y justicia social, es de uso reciente en el debate sobre las ciudades y su futuro; reconociendo que las problemáticas del hábitat exceden lo meramente habitacional, en términos cuantitativos e implican, además, cuestiones relacionadas con factores espaciales, políticos, sociales, económicos y culturales. Sin embargo, a pesar de un proceso de formalización creciente de este derecho, se observa un escaso desarrollo de metodologías de análisis y aplicación del mismo.

Por este motivo, el objetivo principal del presente trabajo de investigación para obtener el grado académico de Magíster en Ciencias del Territorio es iniciar el camino hacia la construcción de una metodología que permita hacer operativo el enfoque del derecho a la ciudad, a fin de evaluar el grado de satisfacción de este derecho, tomando como caso testigo para la aplicación de una variable a la localidad de Punta Lara (Ensenada, Buenos Aires); y que esto constituya un aporte metodológico, en pos de construir conocimiento sobre la ciudad y generar diagnósticos que puedan conformar un soporte para la toma de decisiones de los agentes responsables de elaborar estrategias de intervención en la ciudad. La complejidad del derecho implica, entonces, la convergencia de diferentes saberes que se incluyen entre las Ciencias del Territorio, con el objeto de lograr una visión integradora.

La hipótesis principal es que el desarrollo de una metodología que operacionalice el enfoque del derecho a la ciudad, permitirá aportar al conocimiento del grado de satisfacción del mismo en un recorte de la localidad de Punta Lara -y a partir de una variable específica-, constituyendo un insumo para la toma de decisiones y la implementación de políticas y estrategias de intervención. 


\section{INDICE}

INTRODUCCIÓN

| INTRODUCCIÓN 12

I TEMA Y FUNDAMENTACIÓN 12

I OBJETIVOS E HIPÓTESIS 17

I METODOLOGIA Y PLAN DE ACTIVIDADES

\section{CAPÍTULO 1 | ESTADO DEL CONOCIMIENTO}

1.1 Antecedentes del derecho a la ciudad. Del derecho a la vivienda al derecho a la ciudad

1.1.1 | Ley 388/97 de la República de Colombia (1997)

1.1.2 | Carta Europea de Salvaguarda de los Derechos Humanos en la Ciudad (2000)

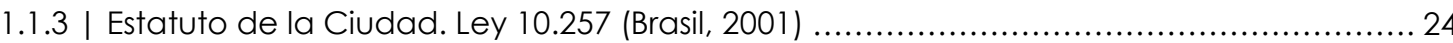

1.1.4 | Carta Mundial del Derecho a la Ciudad (Barcelona, 2005) ......................................2 25

1.1.5 | Carta de Derechos y Responsabilidades de Montreal (2006) ...................................2 28

1.1.6 | Constitución de la República de Ecuador (2008) _.................................................29

1.1.7 | Carta de la ciudad de México por el derecho a la ciudad (2009) ..........................29

1.1.8 | Carta-Agenda Mundial de Derechos Humanos en la Ciudad (2011) ........................ 31

1.1.9 | Ley 14.449 de Acceso Justo al Hábitat (Argentina, 2012) …................................... 32

1.2 | El derecho a la ciudad hoy. ¿̇s posible pensar este derecho en la ciudad actual? ....................33

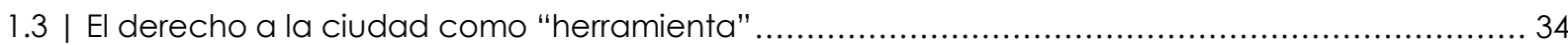

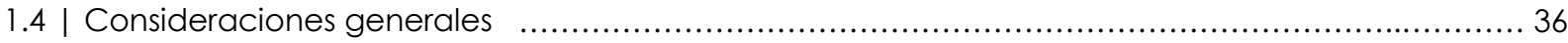

\section{CAPÍTULO 2 | MARCO TEÓRICO. CIUDAD, DERECHO Y HÁBITAT}

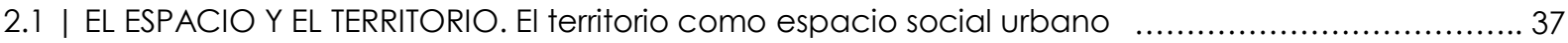

2.2 DERECHO y CIUDAD. La ciudad como espacio de realización de derechos ….........................38

2.3 I DERECHO A LA CIUDAD y HÁBITAT. La complejización del concepto .........................................39

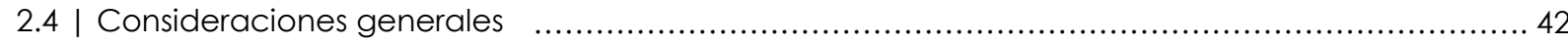




\section{CAPÍTULO 3 | EL CAMINO HACIA LA CONSTRUCCIÓN DE LA METODOLOGÍA DE ANÁLISIS DEL DERECHO A LA CIUDAD}

3.1 | Construcción de Variables, Dimensiones e Indicadores del derecho a la ciudad

3.1.1 | El ejercicio pleno de la ciudadanía y la gestión democrática de la ciudad. Ciudad Democrática

3.1.2 | La promoción del acceso a los servicios básicos. Ciudad Accesible 49

3.1.3 | Igualdad entre todos los habitantes. Ciudad Integradora ...................................... 50

3.1.4 | Respeto por el medio ambiente. Ciudad Sostenible .............................................. 53

3.1.5 | El usufructo equitativo de las ciudades. Ciudad incluyente ....................................54

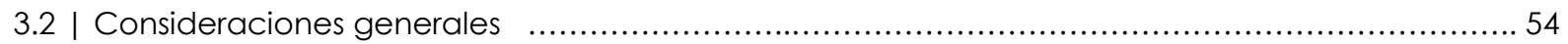

\section{CAPÍTULO 4 | APLICACIÓN METODOLÓGICA. VARIABLE CIUDAD INCLUYENTE}

4.1 El área de estudio

4.1.1 | El contexto general de la investigación. La microrregión del Gran La Plata 61

4.1.2 | El contexto macro. El partido de Ensenada .64

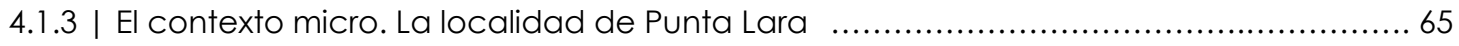

4.2 | Ensayo y aplicación de la variable ciudad incluyente 71

4.2.1 | Consideraciones metodológicas-conceptuales ..................................................... 71

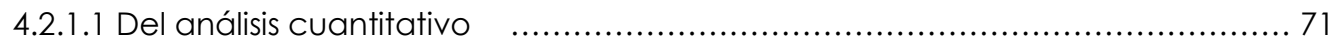

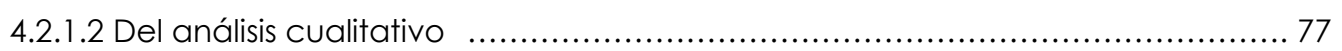

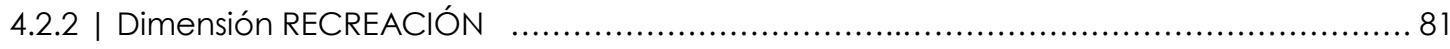

4.2.1.1 Indicador de ESPACIOS VERDES/PÚBLICOS ............................................ 81

4.2.1.2 Indicador de CENTROS DEPORTIVOS RECREATIVOS ….............................. 92

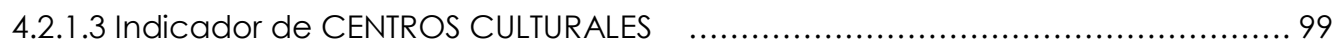

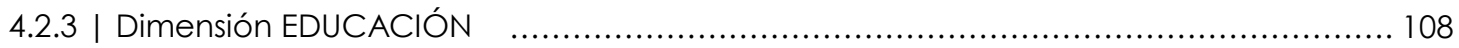

4.2.3.1 Indicador de CENTROS EDUCATIVOS ..................................................... 108

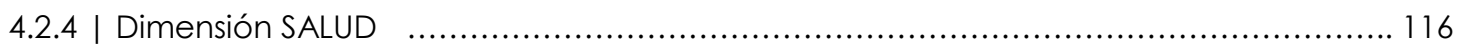

4.2.3.1 Indicador de CENTROS DE SALUD _................................................... 116

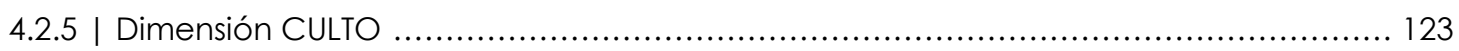

4.2.4.1 Indicador de CENTROS RELIGIOSOS ….............................................. 123

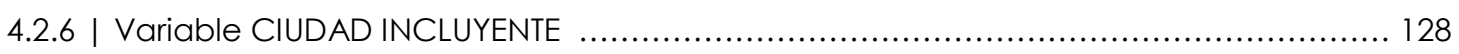

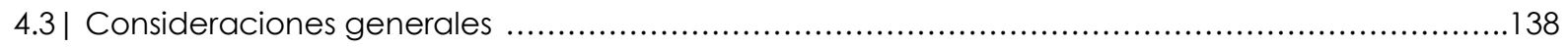



A | Sobre el derecho a la ciudad como enfoque 142
B | Sobre el derecho a la ciudad como herramienta 143
C | Sobre la aplicación metodológica de la herramienta. Variable Ciudad Incluyente 144
D | Continuidades y aperturas 145

\section{ANEXOS}

ANEXOI | Cuestionario Encuestas 152

ANEXO || | Artículos periodísticos

\section{LISTA DE FIGURAS}

Figura 1. Crecimiento poblacional a través de los años. Estimación período 1950-2040.

Figura 2. Distribución de la Población Urbana + Población Total por jurisdicción y densidad de Población Figura 3. Estructuración y articulación: Interrogantes, Objetivos e Hipótesis

Figura 4. Antecedentes del derecho a la ciudad. 1997-2012

Figura 5. Referentes teóricos y metodológicos analizados

Figura 6. Representación gráfica del concepto de "ciudad". Componentes Principales

Figura 7. Principios del derecho a la ciudad

Figura 8. Síntesis del marco teórico-conceptual

Figura 9. Criterios de construcción de las variables, dimensiones e indicadores

Figura 10. Construcción del índice del derecho a la ciudad

Figura 11. Escalas de abordaje de la investigación

Figura 12. Mapa Franja de Proyectos Estratégicos Centro

Figura 13. Mancha urbana. Evolución 1972-2001

Figura 14. Mapa de Usos Reales del Suelo, Ensenada

Figura 15. Imágenes históricas de espacios recreativos de la costa de Punta Lara

Figura 16. Avisos publicitarios para promover el flujo turístico a la Costa de Punta Lara

Figura 17. Mapa de Barrios Populares

Figura 18. Recorte del Área de Estudio 
Figura 19. Esquema síntesis variable Ciudad Incluyente. Dimensiones e Indicadores

Figura 20. Conceptos principales Geografía Cuantitativa

Figura 21. Edad de los encuestados

Figura 22. Resultados encuestas: datos básicos de residencia de población

Figura 23. Espacios verdes/públicos. Superficies aproximadas (en m2)

Figura 24. Fotos representativas Espacios Verdes Públicos

Figura 25. Modalidad de medición de población en área de cobertura espacios verdes/públicos

Figura 26. Análisis de la cobertura de espacios verdes/públicos

Figura 27. Imágenes representativas de diferentes usos del espacio verde público

Figura 28. Resultados encuesta: Uso de los espacios verdes/públicos

Figura 29. Resultados encuesta: Calificación de los espacios verdes/públicos

Figura 30. Resultados encuesta: Suficiencia/Insuficiencia de los espacios verdes/públicos

Figura 31. Ficha metodológica análisis indicador "Espacios verdes/públicos"

Figura 32. Modalidad de medición de análisis de población en área de cobertura Centros Deportivos Recreativos

Figura 33. Análisis de la cobertura de centros recreativos/deportivos

Figura 34. Resultados encuesta: Desarrollo de actividades deportivas en centros municipales

Figura 35. Resultados encuesta: Calificación centros deportivos municipales

Figura 36. Resultados encuesta: Mejoras en relación a centros deportivos

Figura 37. Ficha metodológica análisis indicador "Centros Deportivos Recreativos"

Figura 38. Fotos representativas Centros Culturales y Espacios de Significación Cultural

Figura 39. Modalidad de medición de análisis de población en área de cobertura Centros Culturales

Figura 40. Análisis de la cobertura de centros culturales

Figura 41. Resultados encuesta: Calificación centros culturales

Figura 42. Resultados encuesta: Concurrencia a centros culturales

Figura 43. Resultados encuesta: Centros Culturales identificados

Figura 44. Resultados encuesta: Hitos/Monumentos/Espacios de significancia cultural identificados por encuestados

Figura 45. Ficha metodológica análisis indicador "Centros Culturales"

Figura 46. Fotos representativas Centros Educativos

Figura 47. Modalidad de medición de análisis de población en área de cobertura Centros Educativos

Figura 48. Análisis de la cobertura de centros educativos 
Figura 49. Resultados encuesta: Concurrencia a Centros Educativos

Figura 50. Resultados encuesta: Suficiencia/Insuficiencia de Centros Educativos

Figura 51. Resultados encuesta: Calificación centros educativos

Figura 52. Ficha metodológica análisis indicador "Centros Educativos"

Figura 53. Identificación de Centros de Salud

Figura 54. Modalidad de medición de análisis de población en área de cobertura Centros de Salud

Figura 55. Análisis de la cobertura de centros de salud

Figura 56. Resultados encuesta: Atención médica en centros de salud

Figura 57. Resultados encuesta: Calificación centros de salud

Figura 58. Ficha metodológica análisis indicador "Centros de Salud"

Figura 59. Centros Religiosos, Punta Lara

Figura 60. Resultados encuesta: Asistencia a centros religiosos de la localidad

Figura 61. Ficha metodológica análisis indicador "Centros Religiosos"

Figura 62. Síntesis variable Ciudad Incluyente

Figura 63. Ficha Síntesis de Manzana N79, a partir del análisis de Indicadores de Ciudad Incluyente Figura 64. Ficha Síntesis de Manzana N66, a partir del análisis de Indicadores de Ciudad Incluyente Figura 65. Ficha Síntesis de Manzana $N^{\circ} 42$, a partir del análisis de Indicadores de Ciudad Incluyente Figura 66. Ficha Síntesis de Manzana N7, a partir del análisis de Indicadores de Ciudad Incluyente Figura 67. Ficha Síntesis de Manzana N7A, a partir del análisis de Indicadores de Ciudad Incluyente Figura 68. Ficha Síntesis de Manzana N²0, a partir del análisis de Indicadores de Ciudad Incluyente Figura 69. Ficha Síntesis de Manzana N³0, a partir del análisis de Indicadores de Ciudad Incluyente Figura 70. Ficha Síntesis de Manzana N³3, a partir del análisis de Indicadores de Ciudad Incluyente Figura 71. Relaciones entre variables y dimensiones

\section{LISTA DE MAPAS}

Mapa 1. Proceso de ocupación de la localidad de Punta Lara Mapa 2. Población total por radio censal. Localidad de Punta Lara Mapa 3. Ocupación por parcelas. Mapa 4. Residencia Población Encuestada Mapa 5. Espacios verdes/públicos. Localización Mapa 6. Cobertura espacios verdes/públicos Mapa 7. Centros deportivos recreativos. Localización 
Mapa 8. Cobertura de centros deportivos recreativos

Mapa 9. Centros culturales. Localización

Mapa 10. Cobertura centros culturales

Mapa 11. Centros educativos. Localización

Mapa 12. Cobertura centros educativos.

Mapa 13. Centros de Salud. Localización

Mapa 14. Cobertura centros de salud

Mapa 15. Centros religiosos. Localización

Mapa 16. Síntesis: Centros Identificados

Mapa 17. Síntesis Variable Ciudad Incluyente

\section{LISTA DE TABLAS}

Tabla 1. Población total y Cantidad de Hogares. Relación entre ambos factores

Tabla 2. Ponderación de Indicadores 
INTRODUCCIÓN 


\section{INTRODUCCIÓN}

"El mundo contemporáneo es un mundo urbanizado"

(Blanco, J., Gurevich, R., 2002)

\section{| TEMA Y FUNDAMENTACIÓN}

Blanco y Gurevich (2002) plantean en su libro "Ciudad y ciudadanos. Aportes para la enseñanza de un mundo urbano" una pregunta que no pierde relevancia en el mundo contemporáneo: "¿Por qué decimos que vivimos en un mundo urbanizado?"; discutiendo, a través de ella, acerca de las características de los procesos de urbanización actuales.

La respuesta más común a esta pregunta, sostienen, tiene que ver con la cantidad de población que vive en ciudades ya que "(...) por primera vez en la historia de la humanidad, más de la mitad de los habitantes del planeta viven en algún tipo de área urbana" (Blanco, J., Gurevich, R., 2002). Además, encuentran otras respuestas en las transformaciones que se han producido en las comunicaciones y las condiciones de movilidad (nuevas formas de transporte, acortamiento de las distancias reales entre diferentes puntos del territorio, etcétera).

Pero no se trata simplemente de la cantidad de ciudadanos que habitan las ciudades, sino que estos procesos han generado que las formas de vida se hayan vuelto también urbanas: "Esto implica la existencia de interacciones cotidianas múltiples y cara a cara, la residencia en áreas de población concentrada, el acceso en tiempos 'urbanos' a servicios de todo tipo (...), la inserción en mercados de trabajo urbanos, etcétera" (Blanco, J., Gurevich, R., 2002).

En el caso de América Latina, específicamente, la CEPAL (2012) manifiesta que es una de las regiones que ha experimentado, en las últimas décadas, un importante proceso de crecimiento y urbanización ya que actualmente casi el $80 \%$ de la población vive en ciudades y profundas transformaciones en términos políticos, económicos, socio-culturales y territoriales. De igual modo, las proyecciones acerca de este crecimiento de la población urbana demuestran que las tendencias continúan en esa línea progresiva, como puede observarse en las estimaciones realizadas por UNICEF para el período comprendido entre los años 1950 y 2014 (Figura 1). 

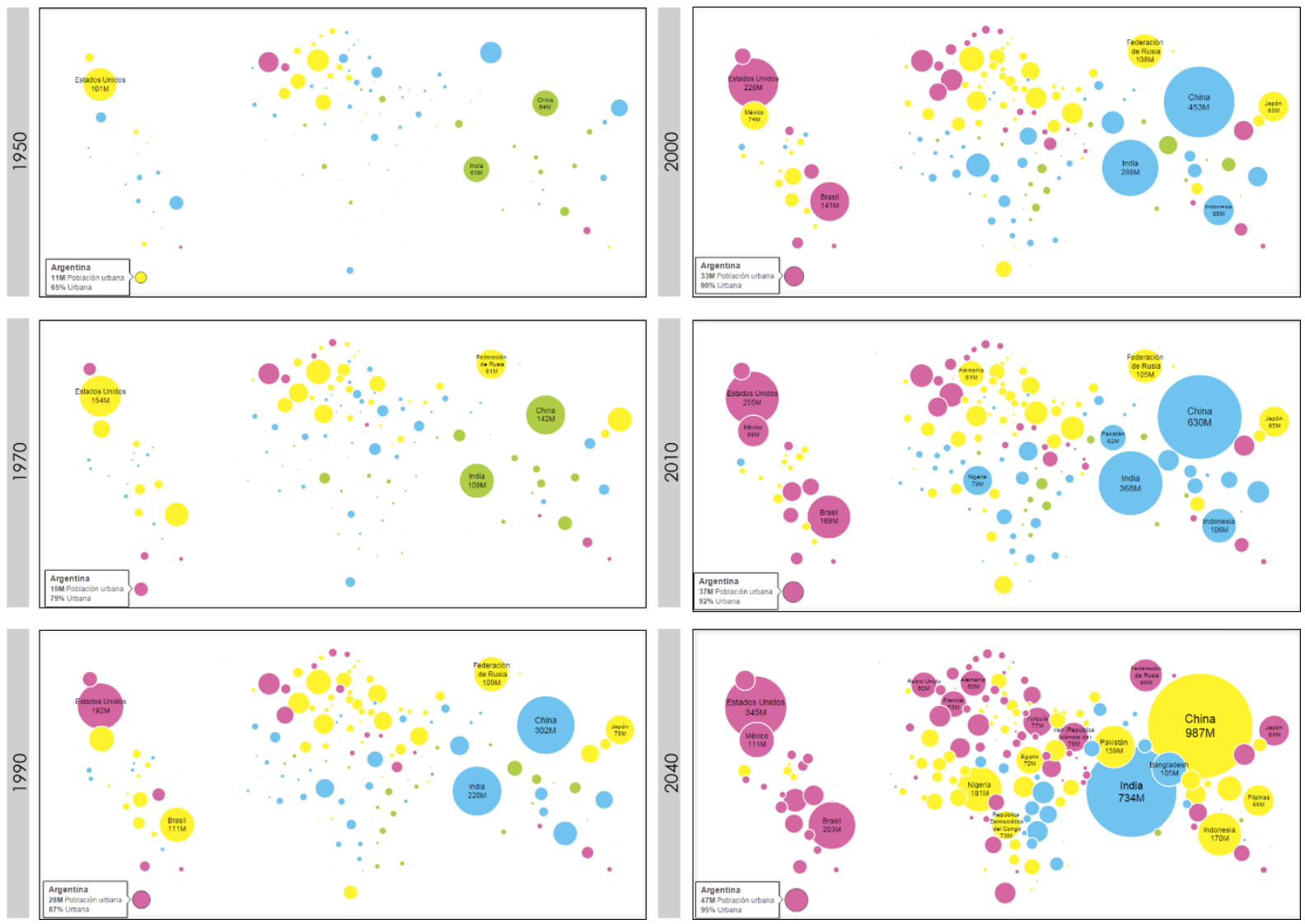

Figura 1. Crecimiento poblacional a través de los años. Estimación período 1950-2040. Elaboración propia. Fuente: UNICEF. Mapa Urbano

Particularmente en el caso de nuestro país, el Instituto Nacional De Estadísticas y Censos (INDEC), define a la "población urbana" como aquella que habita en localidades de más de 2000 habitantes ${ }^{1}$; y el 50\% de esta población reside en seis grandes aglomerados, entre los que se encuentra la Región Metropolitana de Buenos Aires y el Gran La Plata.

Este agrupamiento de población no constituye la única característica de las ciudades actuales, sino que existen otros aspectos que las definen, tales como la concentración de las actividades económicoproductivas bajo un sistema capitalista neoliberal, basado en la búsqueda de beneficios y ganancias; generando pujas constantes entre actores -el Estado, las empresas, la sociedad en general- y segregando a aquellos que no pueden participar de estas dinámicas.

Así, un sistema económico centrado en la generación de ganancias con un aumento progresivo de población, ha generado grandes problemáticas en términos de hábitat, que pueden observarse en la exclusión de vastos sectores de la sociedad y, por ende, la carencia, la marginalidad y el deterioro de la calidad de vida de la población. Además, se observa un proceso de segregación creciente, asociado a la vez a un déficit habitacional no sólo en términos cuantitativos (de cantidad de viviendas), sino en términos cualitativos (calidad e integridad de las viviendas) todo esto sumado a un desarrollo intenso de la urbanización. De esta forma, la vida en las ciudades se ha ido transformando cada vez más en "...un bien de carácter crecientemente exclusivo y excluyente, que socava la posibilidad de constitución del derecho a la ciudad como un universal integrador..." (Perceval, 2011).

\footnotetext{
${ }^{1}$ Glosario del Instituto Nacional de Estadísticas y Censos. https://www.indec.gob.ar/textos_glosario.asp?id=45
} 
Brevemente, a fin de contextualizar el problema de análisis, se identifican algunos datos que reflejan esta situación a nivel nacional. En primera instancia, existe un 12,5\% de la población que no puede satisfacer sus necesidades básicas, según datos del último Censo Nacional del año 2010.
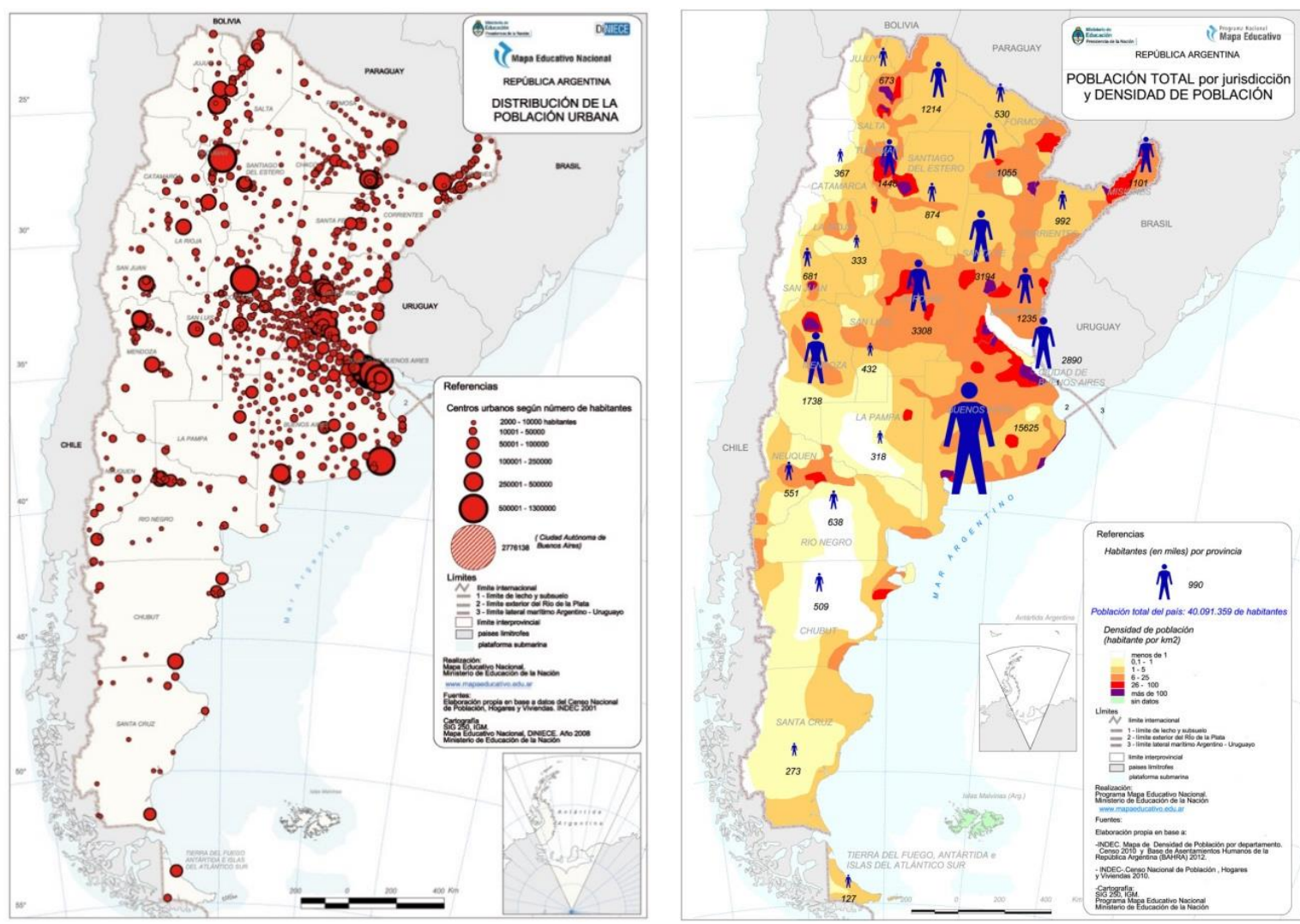

Figura 2. Distribución de la Población Urbana + Población Total por jurisdicción y densidad de Población. Fuente: Programa Nacional Mapa Educativo. Ministerio de Educación. 2013

Más aún, en relación a las condiciones de habitabilidad de la población, el Censo determina que, en promedio, sólo el $51 \%$ de los hogares cuenta con servicios de agua pública dentro de los hogares, y que el porcentaje de propietarios de viviendas se ha reducido en los últimos años, ya que en el año 2001 era de $70,64 \%$ (7.115.508 hogares) y en 2010 el acceso a la propiedad de la vivienda ha disminuido hasta alcanzar el 67,70\% (8.240.293 hogares).

Frente a este panorama, se han dado respuestas a las necesidades de la población a partir de políticas y soluciones sectoriales, en muchos casos de emergencia, sin contemplar la totalidad de los aspectos que implica la problemática habitacional; planteando resoluciones parciales, que no se consolidan en el tiempo.

Incluso algunos de los marcos normativos representan miradas sectoriales, apuntando a la satisfacción de la necesidad de vivienda, sin contemplar la integralidad de lo que implica "habitar". Por ejemplo, la Constitución Nacional de la República Argentina, en el artículo 14 bis manifiesta que, entre los múltiples derechos que se les reconocen a los trabajadores, se debe garantizar el acceso a una "vivienda digna" a todo habitante del territorio argentino. En el caso de la Provincia de Buenos Aires, y en relación al derecho a la vivienda, la Constitución de la Provincia (1994) establece en el artículo 36, inciso 7, que: "...la Provincia promoverá el acceso a la vivienda única y la constitución del asiento del hogar como bien de familia; garantizará el acceso a la propiedad de un lote de terreno apto para erigir su vivienda familiar única y de ocupación permanente, a familias radicadas o que se radiquen en el interior de la Provincia (...)". 
En esta línea, R. Rolnik (2011) en "Informe de la relatora especial sobre una vivienda adecuada como elemento integrante del derecho a un nivel de vida adecuado, y sobre el derecho a la no discriminación en este contexto" (Naciones Unidas, Asamblea General)2 ${ }^{2}$, manifiesta que las políticas públicas de vivienda en Argentina han sido estructuradas sólo en términos de producción de "viviendas completas", de mejoramiento de viviendas, o de consolidación urbana; y que esto se debe, en gran parte, a la ausencia de diagnósticos-marco, que permitan identificar las diferentes dinámicas de urbanización y sus requerimientos. Además, afirma que en el caso de que existan, solo se centran en el déficit en términos cuantitativos y no en términos cualitativos (calidad urbano-ambiental, condiciones de integración social, etc.) (Rolnik, 2011). Más aún, que a pesar de que en los últimos años han intentado diversificarse las políticas públicas de tierra y vivienda -aplicando programas como el "PROMEBA", el "Programa Federal de Mejoramiento de la Vivienda"4 o el "Programa Federal de Emergencia Habitacional"5-, se continúa la tendencia hacia la construcción de viviendas sin basarse en un concepto integral del hábitat.

En concordancia con esta temática, en los últimos años la problemática habitacional y urbana ha sido interpelada y estudiada por diferentes disciplinas y autores, pero muchos de estos se han basado en enfoques fragmentarios que no abordan integralmente las problemáticas, generando, por lo tanto, escasos resultados e incluso, en ocasiones, impactos urbanos negativos (Murillo, Schweitzer, 2010).

Es en este contexto en el que emerge el derecho a la ciudad como un enfoque contemporáneo y que aspira a garantizarse, siendo incorporado particularmente por las administraciones públicas; reconociendo que las problemáticas del hábitat van más allá de la necesidad de "un techo", e implican cuestiones relacionadas con otros factores espaciales y también a aspectos políticos, sociales y económicos.

Así, la relevancia del derecho a la ciudad como enfoque no radica en su modernidad, sino en su capacidad de generar debates, nuevos interrogantes y cuestionamientos acerca de las formas de pensamiento actuales. Como afirma Perceval (2011), "aunque el derecho a la ciudad, al igual que la globalización, no sea en sentido estricto una propuesta nueva, se erige como una propuesta política de ruptura y, por eso, tiene una función provocadora".

Por este motivo, y como manifiesta Harvey (2012) el "derecho a la ciudad tiene que plantearse, no como un derecho a lo que ya existe sino como un derecho a reconstruir y recrear la ciudad (...) es mucho más que un derecho individual o colectivo a los recursos que esta -la ciudad-almacena y protege; es un derecho a cambiar y a reinventar la ciudad de acuerdo con nuestros deseos".

En nuestro país, la Ley de Acceso Justo al Hábitat de la Provincia de Buenos Aires (Ley Nº14.449 del año 2012), es uno de los primeros instrumentos que, a nivel nacional, comienza a proclamarse en relación a este derecho, manifestando que "todos los habitantes de la Provincia tienen garantizado el derecho al uso y goce de la ciudad y de la vivienda, entendiendo a éstos como el derecho a:

a) Un lugar adecuado para vivir en condiciones que favorezcan la integración plena a la vida urbana.

b) Acceder a los equipamientos sociales, a las infraestructuras y a los servicios.

c) Desenvolver apropiadamente las actividades sociales y económicas.

d) Usufructuar de un hábitat culturalmente rico y diversificado"

\footnotetext{
2 Disponible en: http://acnudh.org/wp-content/uploads/2012/03/Informe-Relatora-sobre-vivienda-adecuada-misi\%C3\%B3n-aArgentina-2011.pdf

${ }^{3}$ El Programa Mejoramiento de Barrios "tiene como finalidad mejorar la calidad de vida y contribuir a la inclusión urbana y social e integración de los hogares argentinos de los segmentos más pobres de la población. Su propósito es mejorar de manera sustentable el hábitat de esta población que reside en villas y asentamientos irregulares" (https://www.promeba.gob.ar/programa.php)

${ }^{4}$ El Programa Federal de Mejoramiento de la Vivienda, "está destinado a la terminación, ampliación / refacción de la vivienda de todo grupo familiar que necesita que su actual vivienda sea completada y/o mejorada, cuando a partir de su propio esfuerzo haya iniciado la construcción de su vivienda única, y que no tengan acceso a las formas convencionales de crédito" (http://www.vivienda.gob.ar/mejorvivir/descripcion.html)

5 El Programa Federal de Emergencia Habitacional, "tiene como objetivo tender a solucionar la Emergencia Habitacional y Ocupacional mediante la implementación de planes de vivienda a ejecutarse a través de la acción de Cooperativas de Trabajo para la Construcción constituidas a tal efecto, e integradas fundamentalmente por beneficiarios del Programa Jefes y Jefas de Hogar Desocupados" (http://www.vivienda.gob.ar/emergencia/normativa.html)
} 
La red HIC (Habitat for International Coalition), referente en la temáticas asociadas al derecho a la ciudad, afirma en sus escritos que "el derecho a la ciudad necesita conducir las políticas urbanas a la construcción de una ciudad inclusiva, compartida, digna, equitativa, justa, pacifica, solidaria y ciudadana"; preguntándose cómo implementar este derecho. En esta línea, plantea tres instrumentos fundamentales para incorporarlo en las políticas públicas: las normas jurídicas que permitan desarrollar un marco legal e institucional para promover la inclusión social y territorial; las instancias participativas institucionales esenciales para la concreción de la función social de la ciudad; y, por último, las herramientas de planificación.

Sin embargo, recalcan que no existen fórmulas para la implementación del derecho a la ciudad, sino que cada contexto y situación debe ser relevada y estudiada a fin de encontrar mecanismos propios que permitan acercarse a la concreción del mismo; buscando, además, generar conciencia tanto en las autoridades como en la población: "quizá debamos empezar reconociendo la enorme cantidad de recursos sociales, económicos y culturales con los que contamos como pobladores organizados. Empecemos por sentirnos fuertes, capaces de resolver nuestros problemas y de exigir que nuestra voz sea escuchada" (Asamblea Mundial de pobladores, 2000).

Puede observarse, entonces, que el derecho a la ciudad como enfoque contemporáneo tiene un gran desarrollo teórico y un proceso de formalización creciente a través de nuevos mecanismos e incluso leyes. Sin embargo, faltan desarrollos operativos (como metodologías de análisis y aplicación). Sumado a esto, las visiones parciales de análisis de la ciudad generan diagnósticos que derivan en soluciones también parciales, desintegradas y sectoriales (como políticas de vivienda, de regularización, de construcción de escuelas, etc.).

Por todo ello, es central entender que el derecho a la ciudad "implica un proceso de construcción de conocimiento sobre la ciudad" (Fernández Wagner, 2014) y, tomando este enfoque como eje, analizar las ciudades de forma integral, de manera tal que este análisis permita generar respuestas más completas y abarcadoras de la problemática habitacional. La microrregión del Gran La Plata y la localidad de Punta Lara en particular, no son ajenas a estas problemáticas y, por este motivo, representan una oportunidad para el desarrollo de la presente exploración.

Los interrogantes, entonces, que guían la investigación se concentran en el derecho a la ciudad como construcción teórica emergente y como enfoque para el análisis de un territorio. En definitiva, el interrogante principal al que se pretende dar respuesta es: ¿constituye el derecho a la ciudad un enfoque posible de operacionalizarse?; y, en ese caso, ¿de qué manera puede incorporarse este enfoque para el análisis de un territorio?

De este interrogante principal, surgen otros interrogantes secundarios que son:

(1) ¿Cuál es el aporte que generaría evaluar el derecho a la ciudad? ¿Por qué buscar una metodología de evaluación del derecho a la ciudad?

(2) ¿Cuáles son las variables e indicadores que definen al derecho a la ciudad?

(3) ¿Es posible evaluar estas variables e indicadores en un territorio específico?

(4) ¿Cómo es la percepción de los habitantes en relación al grado de satisfacción del derecho a la ciudad sobre su territorio?

Resulta un desafío el abordaje de este enfoque emergente en términos metodológicos y, por este motivo, la investigación pretende constituir un aporte para poder hacer operativo el derecho a la ciudad; buscando, además, construir conocimiento sobre la ciudad y generar diagnósticos que permitan constituir un soporte para la toma de decisiones de los agentes responsables de elaborar estrategias de intervención en la misma (conocimiento para la acción). 
La tesis se estructura en cuatro capítulos y dos partes diferenciadas. La primera parte se enfoca en la comprensión del derecho a la ciudad como enfoque complejo y actual, reconociendo autores que trabajan sobre la temática y los conceptos principales asociados. En el primero de los capítulos se exploran los antecedentes que existen en relación a este derecho complejo, así como a las estrategias de abordaje metodológicas; mientras que el segundo capítulo estará abocado a los aspectos teóricos relacionados a su comprensión y definición.

La segunda parte abordará la definición de las consideraciones generales en función de la construcción de la herramienta metodológica para la evaluación del grado de satisfacción del derecho a la ciudad, y la aplicación de una de las variables definidas, en un caso testigo. Así, en el tercer capítulo se identificarán los aspectos fundamentales a considerar en la evaluación, definiendo indicadores, dimensiones y variables. Por último, en el cuarto capítulo se procederá a la utilización de la herramienta para la observación del caso testigo; profundizando entonces el análisis desde la evaluación de una única variable específica, a partir de una doble articulación de técnicas cuantitativas y cualitativas; previendo la continuidad de aplicación de las restantes variables en futuras investigaciones.

Finalmente, se plantea un apartado con las conclusiones principales alcanzadas a partir del caso estudiado y en relación a los objetivos planteados para el desarrollo de la presente tesis, en el que se abren nuevos interrogantes que permitirán plantear investigaciones que den continuidad al actual trabajo de investigación.

\section{| OBJETIVOS E HIPÓTESIS}

De acuerdo a los interrogantes que guían la investigación, se plantea como objetivo principal, iniciar el camino hacia la construcción de una metodología que permita hacer operativo el enfoque del derecho a la ciudad, a fin de evaluar el grado de satisfacción de este derecho, tomando como caso testigo para la aplicación de una variable a la localidad de Punta Lara (Ensenada, Buenos Aires)

\section{Los objetivos específicos son:}

(1) Contribuir a la conformación de un marco teórico-conceptual en relación a un enfoque emergente como es el del derecho a la ciudad.

(2) Aportar a la construcción de una herramienta metodológica para una observación sistemática y evaluación del grado de satisfacción del derecho a la ciudad, que constituya un insumo para la toma de decisiones y la implementación de políticas y estrategias de intervención.

(3) Ensayar la aplicación metodológica de la herramienta, en un caso testigo del partido de Ensenada -la localidad de Punta Lara-, a fin de iniciar el camino de reconocimiento del grado de satisfacción del derecho a la ciudad en un territorio específico y verificar la capacidad de operativizar este derecho en una de sus variables.

La hipótesis principal es que el desarrollo de una metodología que operacionalice el enfoque del derecho a la ciudad, permitirá aportar al conocimiento del grado de satisfacción de este derecho en un recorte de la localidad de Punta Lara -y a partir de una variable específica-, constituyendo un insumo para la toma de decisiones y la implementación de políticas y estrategias de intervención.

Y se plantean las siguientes hipótesis específicas:

(1) El enfoque del derecho a la ciudad aporta elementos superadores para evaluar la problemática del hábitat de forma integral, contribuyendo al ejercicio de este derecho.

(2) El derecho a la ciudad como enfoque, puede implementarse para evaluar un territorio, a partir de la descomposición en variables e indicadores.

(3) La experiencia vivencial de los habitantes de un territorio, incide directamente en la percepción de los mismos en relación al derecho a la ciudad; resultando en aspectos fundamentales para la compresión integral del grado de satisfacción de este derecho 

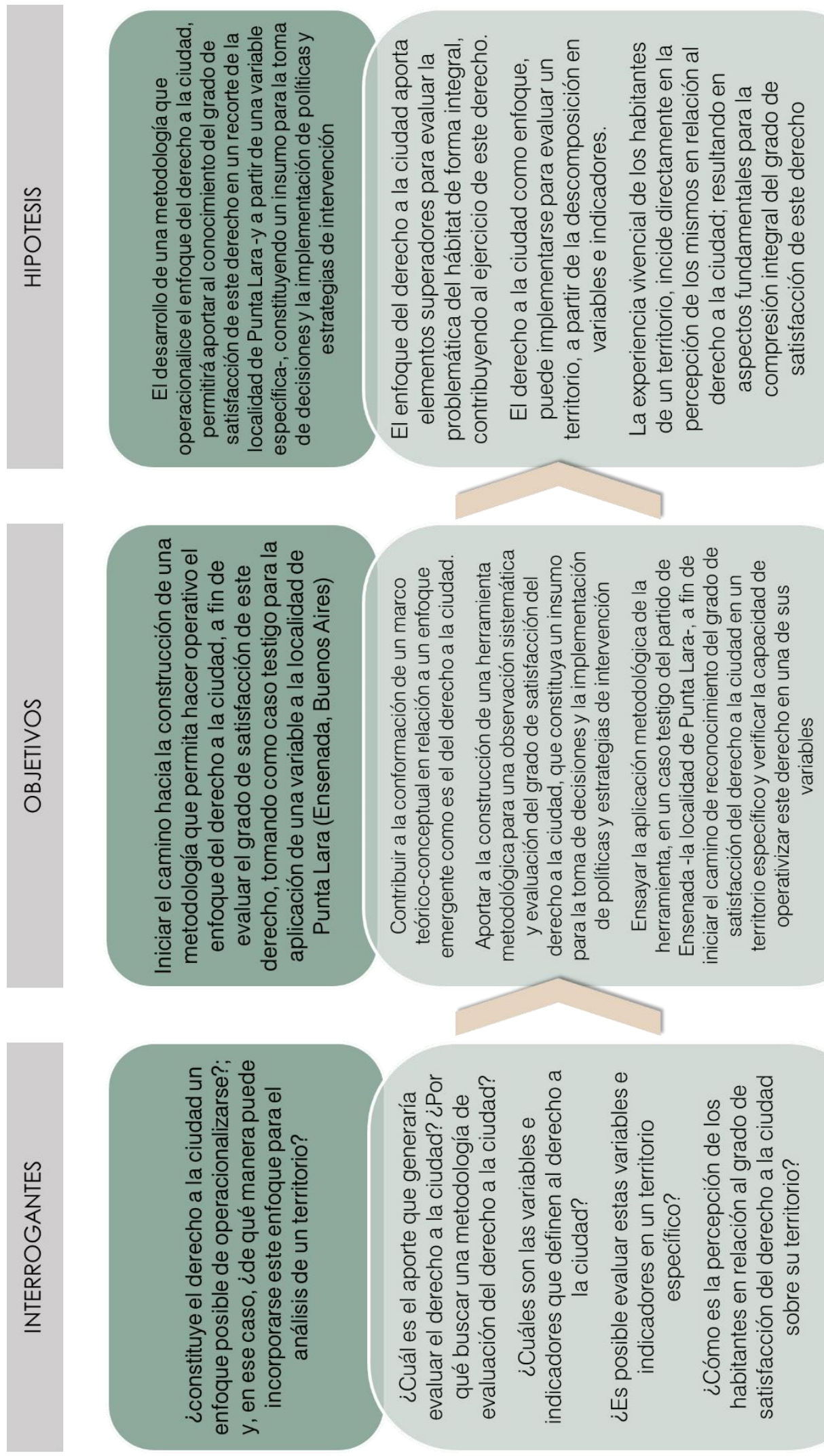


\section{| METODOLOGIA Y PLAN DE ACTIVIDADES}

El perfil metodológico adoptado para el desarrollo de la indagación fue el de una investigación aplicada ya que implica un conocimiento para la acción-, explicativa, empírica, sincrónica -debido a que refiere al estado actual del objeto de estudio-y mixta, utilizando fuentes primarias y secundarias.

A los fines de responder al objetivo de la investigación, se planteó una estrategia metodológica basada en una serie de etapas concatenadas, utilizando diferentes técnicas para la recolección y procesamiento de los datos.

La primera etapa consistió en la elaboración de un marco teórico-conceptual para abordar los conceptos fundamentales que definen la investigación, a partir de un análisis documental y la revisión de bibliografía y autores relevantes, así como antecedentes y experiencias que existan en torno al derecho a la ciudad y su operativización. A partir de la información se elaboraron mapas conceptuales que permitieron integrar y relacionar los conceptos principales.

Como parte de la segunda etapa, se definieron una serie de parámetros generales que permitieran iniciar la construcción metodológica de evaluación del derecho a la ciudad, confeccionando variables que se asocian a los derechos que deben garantizarse en el marco de este enfoque y precisando dimensiones e indicadores para cada una de ellas, que posibiliten su evaluación, siempre desde su expresión en el territorio.

Una vez construidos los aspectos generales de la herramienta, se procedió a la aplicación de una de las variables definidas a un sector de la microrregión del Gran La Plata que hubiera experimentado procesos de crecimiento y expansión urbana, como caso de estudio instrumental ${ }^{6}$. Con esto presente, se seleccionaron una serie de barrios de la localidad de Punta Lara, que respondían a estas características; y se realizaron visitas de campo, registros fotográficos y observaciones, así como lecturas de imágenes satelitales para obtener referencias sobre los temas de interés. El trabajo se apoyó, además, en fuentes de información secundaria procedentes del Censo Nacional, datos suministrados por la Municipalidad y actores claves e indagaciones realizadas por diferentes núcleos y organismos de investigación de la Universidad Nacional de La Plata.

Los resultados obtenidos fueron articulados con las herramientas de espacialización proporcionadas por los Sistemas de Información Geográfica (SIG), permitiendo la construcción de cartografía y elaboración de matrices que hicieron posible la interrelación de los indicadores y dimensiones.

A fin de indagar en los aspectos cualitativos del análisis, se utilizaron dos técnicas complementarias: la observación y la encuesta; que permitieron dar cuenta de la visión de actores residentes en el área de estudio e interpelar los aspectos cuantitativos de la investigación.

Finalmente, la última etapa consistió en la elaboración de conclusiones y confrontación de los resultados obtenidos a partir de la aplicación de variable seleccionada; y la definición de nuevos aspectos que permitan continuar el proceso de investigación.

\footnotetext{
${ }^{6}$ MARRADI, ARCHENTI, PIOVANI (2007) citan a Sake, R (1994) quien define varias tipologías de caso de estudio, y reconoce que, en el estudio de caso instrumental, "el caso cumple el rol de mediación para la comprensión de un fenómeno que lo trasciende. El propósito de la investigación va más allá del caso; éste es utilizado como instrumento para evidenciar características de algún fenómeno o teoría".
} 
PARTE 01 


\section{CAPÍTULO 1 | ESTADO DEL CONOCIMIENTO}

"Las ciudades han cambiado de tal manera que lo que durante el siglo XX se consideró como el principal ámbito de integración, la vivienda, no sólo está cada vez menos garantizada sino que además ya no es suficiente para conseguir la integración y, sobre todo, la igualdad"

(Sánchez, s/f)

El concepto del "derecho a la ciudad" se vincula a Henri Lefebvre, ya que fue quien le dio ese nombre a su libro en la década del '60. Así, pese a no ser el primer autor en acuñar esta idea, el impulso que generó este escrito condujo a grandes transformaciones en la forma de pensar las ciudades. Varios autores retomaron luego el concepto, pero durante mucho tiempo se lo utilizó simplemente como una ampliación del derecho a la vivienda, reconociendo sólo algunos derechos relativos al entorno físico.

El presente capítulo analiza brevemente los antecedentes teóricos y metodológicos que existen en torno a este derecho. Inicialmente se indagó acerca del proceso recorrido en relación a la superación de la identificación de derechos relativos exclusivamente a la vivienda, para alcanzar el reconocimiento del derecho a la ciudad como enfoque que incorpora nuevas garantías.

Seguidamente, se reflexionó acerca de la posibilidad de pensar en la aplicación y el afianzamiento del derecho a la ciudad en las ciudades actuales y la mirada de diferentes autores en torno a esta cuestión. Finalmente, el énfasis se orientó en la necesidad de incorporar y repensar al derecho a la ciudad como una herramienta, capaz de generar conocimiento, diagnósticos macro y propuestas superadoras en pos de la mejora de la calidad de vida de la población.

\section{1 | Antecedentes del derecho a la ciudad. Del derecho a la vivienda al derecho a la ciudad}

En este apartado se analizaron brevemente y a modo de referencia, los antecedentes que dieron lugar a la superación del derecho a la vivienda como espacio integrador de todas las necesidades del hombre; para arribar a discusiones en torno a pensar a la ciudad como ese espacio de integración. 


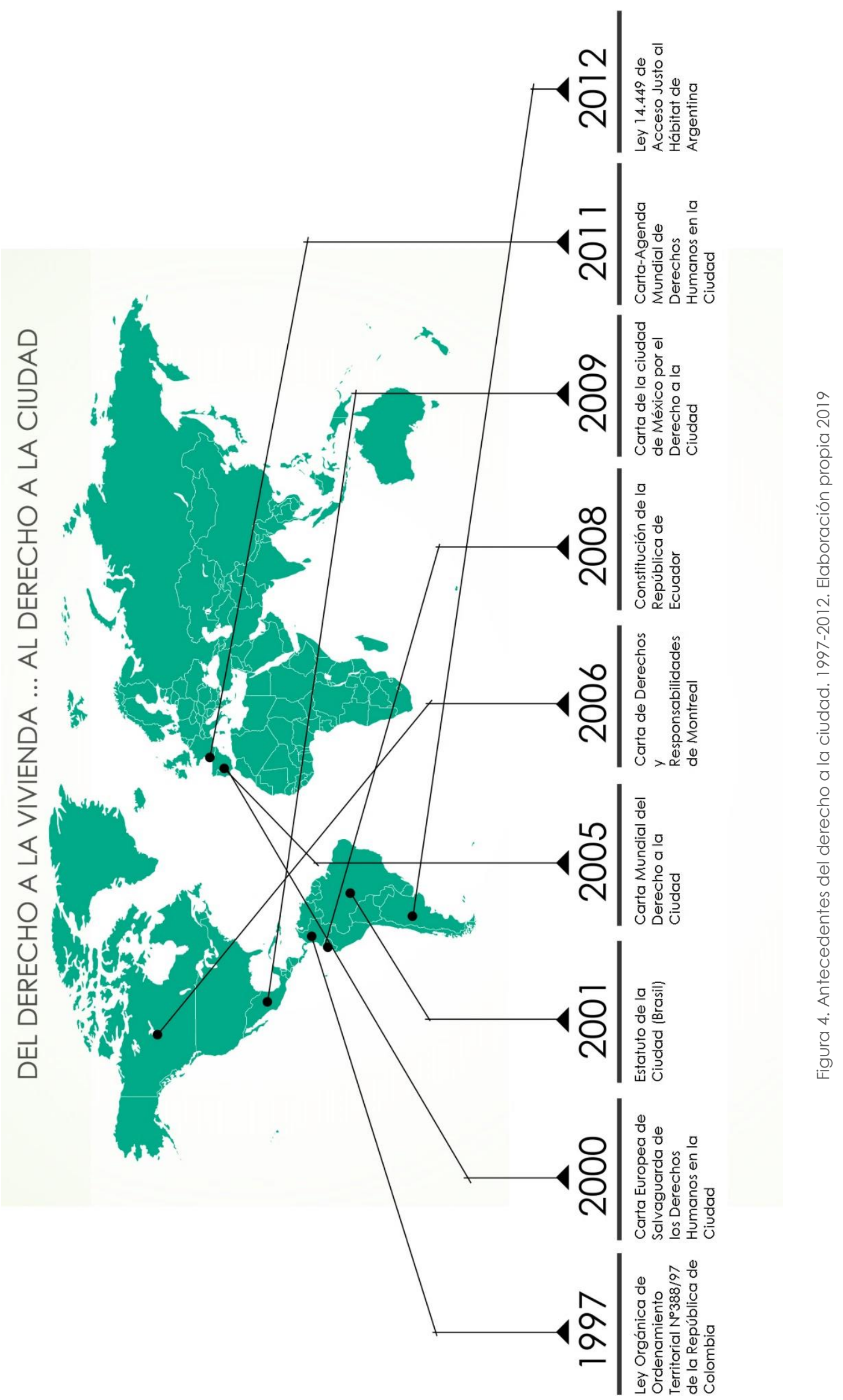




\subsection{1 | Ley 388/97 de la República de Colombia (1997)}

En el año 1997, la República de Colombia sancionó la Ley Orgánica de Ordenamiento Territorial, instrumento para la integración del ordenamiento territorial y ambiental. La Ley surgió como una respuesta ante proceso de urbanización creciente del país y los desequilibrios y desigualdades que esta situación generaba en cuanto a las oportunidades de los habitantes de disfrutar de los beneficios de esa urbanización; así como las insuficiencias en las infraestructuras para abastecer a la población, entre otras problemáticas.

Esta ley es una de las primeras de Latinoamérica que empieza a manifestar la necesidad de garantizar la función social de la propiedad, proteger los recursos naturales, y fomentar la participación de la comunidad en la toma de decisiones para alcanzar estos resultados.

Así, reconoció dentro de sus objetivos "(...) Garantizar que la utilización del suelo por parte de sus propietarios se ajuste a la función social de la propiedad y permita hacer efectivos los derechos constitucionales a la vivienda y a los servicios públicos domiciliarios, y velar por la creación y la defensa del espacio público, así como por la protección del medio ambiente y la prevención de desastres" (Art. 1); proponiendo una serie de principios rectores del ordenamiento territorial (Art.2):

(1) La función social y ecológica de la propiedad;

(2) la prevalencia del interés general sobre el particular;

(3) y la distribución equitativa de las cargas y los beneficios.

Pese a la importancia que significó la definición de estos principios, una de las críticas que puede hacerse a esta manifestación es que no se encuentran definidos conceptualmente en el marco de la ley, lo que abre a diferentes interpretaciones y genera dificultades en su comprensión.

Otro aspecto que resulta significativo es el manejo que se hace en la ley del concepto de la "función pública del urbanismo", entendiendo que es a través del urbanismo que se debe garantizar a todos los habitantes el acceso a vías de comunicación, a las infraestructuras de transporte, a los espacios públicos, a la vivienda y demás servicios, en pos de mejorar la calidad de vida de las personas (Art. 3). En este marco, cabe destacar que la ley otorgaba instrumentos de acción a los diferentes ámbitos de gobierno principalmente a los gobiernos municipales- para reorientar eficazmente el crecimiento urbano y regular el uso del suelo.

Más aún, el cuerpo de la ley destaca la necesidad de la participación democrática, incluyendo a la población y las organizaciones en todas las actividades inherentes a las diferentes acciones urbanísticas; y definiendo mecanismos e instrumentos para garantizar esta participación.

A modo de síntesis, una frase de Juan Martín Caicedo, que resume tanto las expectativas y logros de la ley, como las dificultades y limitaciones que representó su aplicación en Colombia: "La Ley representa un gran avance en nuestra búsqueda por mejores ciudades, por mejores condiciones de hábitat y sostenibilidad y por una justicia en el desarrollo territorial, sin embargo se hace necesario el acompañamiento de los entes capacitados en dicha planificación, consolidando un campo de discusión que permita el total aprovechamiento de los instrumentos alli planteados. De otra forma, corremos el riesgo de centrarnos en uno o dos de ellos, desdibujando su papel en la estructura general del proceso de planeación territorial y echando por tierra el fin último de la Ley misma" (Caicedo, 2007) 


\subsection{2 | Carta Europea de Salvaguarda de los Derechos Humanos en la Ciudad (2000)}

Esta carta, firmada en el año 2000 por más de 400 ciudades de 21 países de Europa, surge como resultado de discusiones que se habían iniciado en Barcelona en el año 1998 (durante el desarrollo de la Conferencia "Ciudades por los Derechos Humanos"), tendientes a promover el respeto, la protección y garantía de los derechos humanos en las ciudades, en un mundo que se reconocía cada vez más urbanizado.

La carta define a la ciudad como el ámbito de trabajo para garantizar los derechos humanos y, por lo tanto, declara que impera la necesidad de precisar derechos que hacen a la condición urbana. Para esto, se basa en una serie de principios que -como veremos a lo largo de este capítulo- se encuentran íntimamente relacionados a todos los antecedentes del enfoque del derecho a la ciudad, que refieren a:

- igualdad de derechos para todas las personas que habitan en las ciudades, sin reparar en su nacionalidad o condición;

- libertad, también asociado al principio anterior;

- $\quad$ protección a la población más vulnerable;

- solidaridad entre las autoridades estatales y los ciudadanos, y entre los ciudadanos entre sí;

- cooperación internacional, entre las diferentes ciudades y países;

- y de subsidiariedad, entendiendo que deben definirse roles y responsabilidades para las diferentes instancias del Estado (Estado-regiones-ciudades).

En este marco, resulta interesante la categorización y el reconocimiento de un conjunto de derechos a todos los ciudadanos. En principio, derechos civiles y políticos, que incluyen el derecho a la participación en las decisiones políticas, a la asociación, reunión y manifestación y el derecho a la información, entre otros. Además, derechos económicos, sociales, culturales y ambientales, entre los que se encuentran el acceso a la educación, al trabajo, a la vivienda, a la cultura, a la salud, a la recreación; y también a una ciudad sostenible y armoniosa. Asimismo, derechos relativos a la administración democrática local, garantizando la eficacia de los servicios públicos en base a las necesidades de la población, así como la transparencia de las decisiones de las autoridades locales.

Otro aspecto a destacar es que delinea -aunque brevemente- mecanismos para garantizar estos derechos a los ciudadanos. En este sentido, la carta manifiesta: "El compromiso que adoptamos aquí se dirige a mujeres y hombres de nuestro tiempo. No pretende ser exhaustivo y su alcance dependerá de cómo los habitantes de la ciudad lo harán suyo" (Carta Europea de Salvaguarda de los Derechos Humanos en la Ciudad, 2000)

\subsection{3 | Estatuto de la Ciudad. Ley 10.257 (Brasil, 2001)}

La Ley 10.257 de Brasil, más conocida como el Estatuto de la Ciudad, se promulgó en el año 2001 luego de un profundo, innovador y extenso proceso participativo, que logró la articulación entre diferentes instancias del Estado (Gobierno Federal y gobiernos municipales) y la sociedad en su conjunto, con el objetivo de generar un marco regulador nacional de la política urbana, fomentando la transparencia en los procesos de toma de decisiones.

Como muchos de los países de Latinoamérica, el proceso de urbanización que se dio en Brasil fue rápido e intenso, acarreando grandes dificultades para la población. Por este motivo, la ley vino a dar respuesta a estas problemáticas y transformaciones, incorporando nuevos conceptos y enfoques, "...de modo a evitar y corregir las distorsiones del crecimiento urbano y sus efectos negativos sobre el medio ambiente..." (Estatuto de la Ciudad. Ley 10.527 de Brasil). Además, se promovía un ordenamiento y control del uso del suelo con el objeto de evitar efectos negativos como un uso inadecuado del mismo, el deterioro y la contaminación. De igual modo, se planteaba una justa distribución de las cargas y los beneficios generados por el proceso de urbanización. 
Según Rolnik (2001), se basa en cuatro dimensiones fundamentales: "(...) consolida un nuevo marco conceptual jurídico-político para el derecho urbanístico, aportando elementos para la interpretación del principio constitucional de la función social de la ciudad y de la propiedad urbana; reglamenta y crea nuevos instrumentos para la construcción de un nuevo orden urbano por parte de las municipalidades; sugiere procesos para la gestión democrática de las ciudades e identifica estrategias e instrumentos de regularización de asentamientos informales en áreas públicas y privadas".

En términos conceptuales, el reconocimiento más importante que hace el Estatuto es definir que el "derecho a la propiedad" se encuentra asociado al de "función social" del suelo. Así, en el primer artículo de la ley se define que el "...Estatuto de la Ciudad establece normas de orden público e interés social que regulan el uso de la propiedad urbana en pro del bien colectivo, de la seguridad y del bienestar de los ciudadanos, así como el equilibrio ambiental." (Estatuto de la Ciudad. Ley 10.527 de Brasil), enfatizando la necesidad de ponderar los derechos colectivos por encima de los individuales.

Entre los derechos que el Estatuto reconoce, el artículo 2 hace énfasis, principalmente, en las directrices generales de la política urbana, entendiendo que se debe "garantizar el derecho a contar con ciudades sustentables, entendido como el derecho a la tierra urbana, a la vivienda, al saneamiento ambiental, a la infraestructura urbana, al transporte y a los servicios públicos, al trabajo y al esparcimiento, para las generaciones presentes y futuras...", promoviendo una "...gestión democrática a través de la participación de la población y de asociaciones representativas de los diferentes sectores de la comunidad...", y la "...cooperación entre los gobiernos, la iniciativa privada y los demás sectores en el proceso de urbanización, atendiendo al interés social..." (Estatuto de la Ciudad. Ley 10.527 de Brasil).

En términos instrumentales, es valioso el aporte que hace el Estatuto ya que no sólo define que los gobiernos municipales deben ser los encargados de formular políticas territoriales y de uso del suelo, sino que, además, les otorga una serie de instrumentos urbanísticos para lograrlo, buscando el equilibrio entre los intereses colectivos e individuales.

Se reconocen entonces, instrumentos que intentan evitar la especulación mediante la retención de terrenos, que genera un aumento del valor del suelo segregando cada vez más a la población y limitando el acceso a derechos básicos; diferenciar entre el derecho a la propiedad y la potencialidad del terreno, según el plan de ciudad que se tenga; consagrar la idea del suelo creado, y brindar mecanismos para regularizar los asentamientos informales consolidados. En esta idea de primar lo colectivo por sobre lo individual se hace hincapié, además, en la necesidad de ampliar el espacio de la ciudadanía, fomentando la participación ciudadana en la toma de decisiones sobre la ciudad que se desea; estableciendo nuevas interrelaciones entre los actores que la conforman (el Estado, la comunidad y los agentes privados).

En síntesis, "...la ley federal de 2001 proporciona un apoyo legal coherente a los municipios comprometidos para enfrentarse a los graves problemas urbanos, sociales y ambientales que han afectado directamente las condiciones de la vida diaria de la población urbana", y así "...confirmó y amplió el papel político-legal fundamental de los municipios en la formulación de las directivas para la planificación urbana, y para la conducción del proceso de desarrollo y gestión urbanos" (Fernández, s/f).

\subsection{4 | Carta Mundial del Derecho a la Ciudad (Barcelona, 2005)}

Otro de los avances significativos en torno al derecho a la ciudad fue la elaboración de una Carta Mundial de Derecho a la Ciudad, debido a que es un instrumento que define un alcance que excede a un país o región (como los analizados hasta el momento). Pese a que la Carta se trató en numerosos encuentros (I Foro Social de las Américas, en Quito en 2004; Foro Mundial Urbano, en Barcelona en 2004; Foro Social Mundial, en Porto Alegre en 2005), constituye un antecedente significativo debido a que no sólo se definen conceptos centrales del derecho a la ciudad sino que, además, se realizan fuertes críticas respecto a la situación de las ciudades. 
Así, se manifiesta que "...los modelos de desarrollo implementados en la mayoría de los países empobrecidos se caracterizan por establecer niveles de concentración de renta y de poder que generan pobreza y exclusión, contribuyen a la depredación del ambiente y aceleran los procesos migratorios y de urbanización, la segregación social y espacial y la privatización de los bienes comunes y del espacio público. Estos procesos favorecen la proliferación de grandes áreas urbanas en condiciones de pobreza, precariedad y vulnerabilidad ante los riesgos naturales. Las ciudades están lejos de ofrecer condiciones y oportunidades equitativas a sus habitantes..." (Carta Mundial del Derecho a la Ciudad, 2005).

Frente a estas situaciones -y luego de un prolongado proceso de discusión y debate entre diferentes organizaciones y redes de la sociedad civil de diversos países-, la Carta pretende dar respuestas tendientes a suprimir las diferencias y la exclusión a la que está sometida la población y generar antecedes para el reconocimiento de derechos a todos los ciudadanos, asumiendo "...el desafío de construir un modelo sustentable de sociedad y vida urbana, basado en los principios de solidaridad, libertad, equidad, dignidad y justicia social..." (Carta Mundial del Derecho a la Ciudad, 2005).

La Carta se basa en una serie de principios fundamentales:

- el ejercicio pleno de la ciudadanía y la gestión democrática de la ciudad, entendiendo que deben ser las ciudades las que contengan los ámbitos necesarios para que los ciudadanos puedan realizarse en términos políticos, económicos, culturales, sociales; y, por consiguiente, se otorgue el derecho a la participación democrática en sus diferentes formas;

- la función social de la ciudad y la propiedad urbana, otorgando a los ciudadanos el usufructo pleno de los recursos que la ciudad ofrece, priorizando el interés social, cultural y ambiental; y también instando a definir estrategias e instrumentos para garantizar el aprovechamiento pleno del suelo urbano, desalentando los procesos especulativos y la retención ociosa de suelo urbano;

- la igualdad y no discriminación, enfatizando que los derechos deben garantizarse a todas las personas que habiten en las ciudades, sin excluir a nadie;

Además, hace hincapié en otros principios que también resultan importantes para garantizar este derecho, como son: la protección especial de grupos de personas en situación de vulnerabilidad, por habitar áreas de riesgo ambiental, por encontrarse en situaciones de pobreza, de violencia, de discapacidad, o por su edad, entre otras cuestiones; el compromiso social del sector privado, en concordancia con la función social de la ciudad y la propiedad, instando a los gobiernos a fomentar la participación de los sectores privados en el desarrollo de las ciudades; y el impulso de la economía solidaria y políticas impositivas progresivas, que aseguren una distribución justa de los recursos para la implementación de las políticas sociales.

La Carta define al derecho a la ciudad como "...el usufructo equitativo de las ciudades dentro de los principios de sustentabilidad, democracia, equidad y justicia social. Es un derecho colectivo de los habitantes de las ciudades, en especial de los grupos vulnerables y desfavorecidos, que les confiere legitimidad de acción y de organización, basado en sus usos y costumbres, con el objetivo de alcanzar el pleno ejercicio del derecho a la libre autodeterminación y un nivel de vida adecuado ..." (Carta Mundial del Derecho a la Ciudad, 2005). Esto supone un avance en los enfoques sobre la mejora de la calidad de vida de la población, centrados generalmente en garantizar el acceso a la vivienda y ciertos equipamientos públicos, sin contemplar otros derechos económicos, civiles, ambientales, culturales.

La segunda parte de la Carta reconoce "derechos relativos al ejercicio de la ciudadanía y a la participación en la planificación, producción y gestión de la ciudad", definiendo que las ciudades deben garantizar los espacios para la participación ciudadana y reconocer los procesos de las iniciativas populares en torno al desarrollo urbano. También, que se deben aplicar políticas eficaces contra la corrupción promoviendo la transparencia en la toma de decisiones y en la gestión de las ciudades.

Además, se busca promover la producción social del hábitat, debiendo las ciudades establecer mecanismos, instrumentos y capacitaciones para tal fin. En concordancia con esto, se manifiesta el 
derecho a la participación política, a partir de la elección de representantes y también de la cooperación en la definición de políticas públicas, presupuestos y programas a partir del acceso a debates y audiencias públicas en torno a temáticas de la ciudad.

Otro aspecto que se manifiesta es el derecho al desarrollo urbano equitativo y sustentable, entendiendo que se debe alcanzar un equilibrio entre el desarrollo urbano y la protección del patrimonio, promoviendo una ciudad integrada, equitativa y sin exclusiones; integrando en las políticas el tema de la seguridad, particularmente como un atributo del espacio público. También la Carta reconoce que las ciudades deben prevenir la contaminación y tender a un crecimiento y ocupación ordenada del territorio, garantizando el derecho a un medio ambiente sano y sostenible.

El artículo VI de la Carta se enfoca en el derecho a la información pública, instando a que todos los ciudadanos puedan solicitar y tener acceso a información completa y transparente relativa a la gestión administrativa y financiera de cualquier órgano perteneciente a la administración de la ciudad, del poder legislativo y del poder judicial así como de aquellas empresas o agentes privados que presten servicios públicos. También, en relación a la necesidad de apoyar a la población en condición vulnerable, la carta manifiesta que "...Toda persona o grupo organizado, y muy especialmente quienes auto producen su vivienda y otros componentes del hábitat, tiene derecho a obtener información sobre la disponibilidad y ubicación de suelo adecuado, los programas habitacionales que se desarrollan en la ciudad y los instrumentos de apoyo disponibles" (Carta Mundial del Derecho a la Ciudad, 2005).

Junto a estos derechos se reconocen otros como son el derecho a la libertad e integridad, a la asociación, reunión, manifestación y uso democrático del espacio público urbano, debiendo las ciudades garantizar espacios para tal fin. Igualmente, se distinguen el derecho a la justicia promoviendo la protección de la sociedad y el derecho a la seguridad pública, la convivencia pacífica, solidaria y multicultural -haciendo referencia a uno de los principios fundamentales de la Carta tendiente a la no discriminación de ningún tipo-.

La tercera parte de la Carta se enfoca en aquellos derechos de orden económico, social, cultural y ambiental, con mayor expresión sobre el territorio. En esta línea, se manifiesta que las ciudades deben garantizar el acceso los servicios públicos domiciliarios y urbanos -y tarifas asequibles-, (agua potable, recolección de residuos, energía y telecomunicaciones), así como a equipamientos de salud, educación, abastecimiento y recreación. De forma semejante, el derecho a la movilidad urbana debe poder satisfacerse con un sistema de transporte público adecuado para toda la población, incluidos aquellos ciudadanos con discapacidades.

A continuación, la Carta reconoce dos derechos fundamentales que deben poder satisfacerse dentro de las ciudades: el derecho a la vivienda y el derecho al trabajo. En relación al primero, las definiciones que se realizan son amplias, ya que no se enfoca simplemente en la vivienda como lugar físico, sino que también se manifiesta que "...los gastos de las viviendas sean soportables de acuerdo a sus ingresos; que las viviendas reúnan condiciones de habitabilidad, que estén ubicadas en un lugar adecuado y se adapten a las características culturales y étnicas de quienes las habitan" (Carta Mundial del Derecho a la Ciudad, 2005). En este marco también se resalta la necesidad de garantizar este derecho a la población en condición de vulnerabilidad (ya sea por ser víctimas de violencia, o por su edad, o por la falta de recursos), mediante la implementación de planes de vivienda, la construcción de albergues y refugios, entre otros instrumentos. Se hace hincapié, además, en la seguridad de tenencia de la vivienda a partir de la aplicación de instrumentos jurídicos que garanticen la protección frente a situaciones como desalojos o desplazamientos forzados.

En relación al derecho al trabajo, se manifiesta que "Las ciudades, en corresponsabilidad con las autoridades nacionales, deben contribuir, en la medida de sus posibilidades, a la consecución del pleno empleo en la ciudad. Asimismo, deben promover la actualización y la recalificación de los trabajadores, empleados o no, a través de la formación permanente..." (Carta Mundial del Derecho a la Ciudad, 2005); 
y junto a esto se expresa que se debe asegurar la igualdad para todos los trabajadores, garantizando condiciones de trabajo dignas y combatiendo situaciones de informalidad.

Finalmente, la carta dispone obligaciones para el Estado como principal responsable de garantizar, satisfacer y promover el derecho a la ciudad; instando, asimismo, a las organizaciones sociales y la población en general a sumarse, asumiendo responsabilidades de difusión y socialización del derecho a la ciudad y de exigir su efectivo cumplimiento. Más aún, se manifiesta que "Las ciudades deben establecer, conjuntamente con los habitantes, mecanismos de evaluación y monitoreo mediante un sistema eficaz de indicadores del derecho a la ciudad, con diferenciación de géneros, para asegurar el Derecho a la Ciudad con base en los principios y normas de esta Carta" (Carta Mundial del Derecho a la Ciudad, 2005).

\subsection{5 | Carta de Derechos y Responsabilidades de Montreal (2006)}

La Carta de Montreal del año 2006, pese a ser específica para esa ciudad, resulta un antecedente valioso debido a que, al igual que el Estatuto de la Ciudad de Brasil, representa un instrumento jurídico adoptado por un gobierno, a diferencia de las iniciativas que se dieron paralelamente por parte de organismos y redes de la sociedad civil -como es la Carta Mundial por el Derecho a la Ciudad-

En coincidencia con los antecedentes analizados, se reconocen derechos a todos los habitantes y las autoridades locales se comprometen a adquirir responsabilidades específicas para poder garantizarlos. Se valora a la Carta como un instrumento puesto a disposición de los ciudadanos para "...que puedan inspirarse en ella en la vida cotidiana, al igual que en el ejercicio de sus derechos y responsabilidades..." (Carta de Derechos y Responsabilidades de Montreal, 2006), y también como una herramienta de reclamo ante una vulneración de los mismos.

Nuevamente el énfasis está puesto en la ciudad y así se lo reconoce en el primer artículo de la Carta, sosteniendo que es "... un lugar de convivencia donde se debe promover la dignidad e integridad humanas, así como la tolerancia, la paz, la inclusión y la igualdad entre todas las ciudadanas y todos los ciudadanos" (Carta de Derechos y Responsabilidades de Montreal, 2006).

En la sección de mayor valor de la Carta, se identifican una serie de principios y valores que deben respetarse: la dignidad humana, el respeto, la justica, la equidad, la transparencia en las decisiones del Estado, y la protección del medio ambiente para garantizar un desarrollo sostenible a las generaciones actuales y futuras.

Los derechos que se adjudican a los ciudadanos son numerosos, así como las cuestiones sobre las cuales el Estado se hará responsable. En primera instancia, se reconoce el derecho a una vida democrática, estimulando la participación ciudadana en los asuntos municipales como una forma de reforzar el sentimiento de pertenencia a la ciudad y promover una ciudadanía activa; comprometiéndose el Estado a proporcionar a los ciudadanos la información necesaria, generar instrumentos de participación (por ejemplo, consultas públicas), combatir la discriminación y fomentar la igualdad.

También el derecho a una vida económica y social, - aunque no se define específicamente en qué consiste este derecho-; comprometiéndose el Estado a tomar medidas para garantizar a la población viviendas adecuadas en términos de salubridad y seguridad, particularmente a la población vulnerable por su condición de bajos ingresos económicos, y garantizar también el acceso a agua potable.

El derecho a una vida cultural también se encuentra reconocido, por lo cual el Estado se responsabiliza de tomar medidas para proteger y valorar el patrimonio, fomentar y promover las actividades culturales y el uso de los espacios culturales. En relación a lo anterior, se manifiesta la necesidad de garantizar el derecho al esparcimiento, las actividades físicas y deportivas, para lo cual el Estado decide habilitar infraestructura para el desarrollo de las mismas, promoviendo el acceso a las actividades y las instalaciones comunitarias pertinentes para realizarlas. 
Adicionalmente, se reconoce el derecho a la seguridad, entendiendo que debe adecuarse el territorio para hacerlo más seguro, particularmente los espacios de uso público (parques, instalaciones comunitarias y recreativas). De igual modo, se proponen medidas preventivas que apunten a concientizar a la ciudadanía en colaboración con los responsables de la seguridad pública a fin de preservar la integridad física de las personas y los bienes.

Además, se debe garantizar el derecho al medio ambiente y al desarrollo sostenible, instando a la reducción de desechos, el reciclaje, la protección y valoración de los recursos, así como a la mejora de la calidad del aire, el suelo y los ríos; fomentando la responsabilidad cívica de los ciudadanos en relación a estos aspectos. En concordancia, el Estado se compromete a promover la oferta y distribución equitativa de los servicios municipales de calidad; sin embargo, cabe destacar que no se encuentran plenamente definidos cuáles son estos servicios.

En síntesis, puede observarse que el valor de la Carta de Derechos y Responsabilidades de Montreal reside en su compromiso con los derechos humanos, compromisos que busca instrumentar en su ámbito territorial debido al carácter vinculante de la misma.

\subsection{6 | Constitución de la República de Ecuador (2008)}

La Constitución de la República de Ecuador sancionada en 2008, define un modelo de desarrollo diferente en búsqueda de "Una nueva forma de convivencia ciudadana, en diversidad y armonía con la naturaleza, para alcanzar el buen vivir (...)" (Constitución de la República de Ecuador, 2008).

A fin de alcanzar el "buen vivir" (o "sumak kawsay", como se define en la Constitución), se precisan múltiples derechos como el acceso al agua y alimentación, a un ambiente sano, a la comunicación y la información, a la cultura, la ciencia, la educación, a la salud, al trabajo y la seguridad, entre otros; y se reconoce como uno de los deberes primordiales del Estado el "...Garantizar sin discriminación alguna el efectivo goce de los derechos establecidos en la Constitución y en los instrumentos internacionales..." (Constitución de la República de Ecuador, 2008).

La clasificación que hace de estos derechos resulta singular, ya que supera la clásica división en derechos económicos, políticos, sociales, culturales, entre otros; y los divide de acuerdo a las temáticas a las que refieren, definiendo así derechos "del buen vivir", derechos de participación, derechos de libertad, derechos de las comunidades y pueblos nacionales; enfatizando la similar importancia de estos y aludiendo la existencia de derechos que deben reclamarse colectivamente (por ejemplo, los derechos de las comunidades).

En el marco del derecho a la ciudad, resulta un instrumento novedoso y definitorio de debido a que es una de los primeros Estados en otorgar carácter constitucional a este derecho -pese a que no realiza demasiadas especificaciones-, manifestando en su artículo 31 que "Las personas tienen derecho al disfrute pleno de la ciudad y de sus espacios públicos, bajo los principios de sustentabilidad, justicia social, respeto a las diferentes culturas urbanas y equilibrio entre lo urbano y lo rural. El ejercicio del derecho a la ciudad se basa en la gestión democrática de ésta, en la función social y ambiental de la propiedad y de la ciudad, y en el ejercicio pleno de la ciudadanía" (Constitución de la República de Ecuador, 2008).

\subsection{7 | Carta de la ciudad de México por el derecho a la ciudad (2009)}

La Carta de la ciudad de México por el derecho a la ciudad se enfoca en aspectos muy similares a la carta Mundial por el Derecho a la ciudad del año 2005, la cual se reconoce como antecedente. Surge de una iniciativa de trabajo entre el gobierno de la ciudad y diversas organizaciones del movimiento popular urbano y se plantea como objetivos: "Contribuir a la construcción de una ciudad incluyente, habitable, justa, democrática, sustentable y disfrutable; contribuir a impulsar procesos de organización social, fortalecimiento del tejido social y construcción de ciudadanía activa y responsable; contribuir a la construcción de una economía urbana equitativa, incluyente y solidaria, que garantice la inserción 
productiva y el fortalecimiento económico de los sectores populares" (Carta de la ciudad de México por el Derecho a la Ciudad, 2009).

Define al derecho a la ciudad como el "... usufructo equitativo de las ciudades dentro de los principios de sustentabilidad, democracia, equidad y justicia social. Es un derecho colectivo de los habitantes de las ciudades, que les confiere legitimidad de acción y de organización, basado en el respeto a sus diferencias, expresiones y prácticas culturales, con el objetivo de alcanzar el pleno ejercicio del derecho a la libre autodeterminación y a un nivel de vida adecuado..." (Carta de la ciudad de México por el derecho a la ciudad, 2009), reconociendo como fundamentos estratégicos del derecho a la ciudad:

- al ejercicio pleno de los derechos humanos en la ciudad ("Por una ciudad de derechos humanos");

- a la función social de la ciudad, de la tierra y de la propiedad ("Por una ciudad para todos: incluyente, solidaria, equitativa"):

- a la gestión democrática de la ciudad ("Por una ciudad políticamente participativa y socialmente corresponsable");

- a la producción democrática de la ciudad y en la ciudad ("Por una ciudad socialmente productiva");

- al manejo sustentable y responsable de los bienes naturales, patrimoniales y energéticos de la ciudad y su entorno ("Por una ciudad viable y ambientalmente sustentable");

- y al disfrute democrático y equitativo de la ciudad ("Por una ciudad abierta, libre, crítica y lúdica")

En este sentido, se entiende como un derecho colectivo y complejo, en el que existen aspectos que "contribuyen más directamente a construir una ciudad incluyente, democrática, sostenible, productiva, educadora y habitable (segura, saludable, convivencial y culturalmente diversa)" (Carta de la ciudad de México por el derecho a la ciudad, 2009).

Los avances se observan en torno a las definiciones que se realizan acerca del modo de implementación de este derecho, de qué incluye y de qué manera puede alcanzarse; estableciendo "lineamientos" para su ejecución. A estos fines, plantea una matriz en la que indica, por un lado, la ciudad que se quiere ("ciudad democrática, ciudad incluyente, ciudad sostenible, ciudad productiva, ciudad educadora, ciudad habitable") y, por el otro, los fundamentos estratégicos del derecho a la ciudad mencionados previamente, reconociendo cuáles de estos constituyen aspectos estratégicos a cumplimentar, cuáles son de apoyo imprescindible y cuáles son complementarios, al mismo tiempo que se definen obligaciones y responsabilidades para las entidades públicas y la población en general.

A partir de esta matriz, define para cada "tipo de ciudad" que se quiere consolidar (por ejemplo, una ciudad democrática), los derechos que deben garantizarse a la población (como el derecho a la libertad de opinión y expresión, derecho a la asociación, derecho a la manifestación, entre otros) y las cuestiones que deben realizarse para alcanzar cada fundamento estratégico. Por ejemplo, "para democratizar la función social de la ciudad y la propiedad se debe: fortalecer la participación social de todas las personas en el diseño, seguimiento y evaluación de la política urbana (....)" (Carta de la ciudad de México por el derecho a la ciudad, 2009).

En su tercer capítulo, la carta define las obligaciones y responsabilidades para cada uno de los que habitan y construyen la ciudad, entendiendo que "Las instancias gubernamentales, las organizaciones sociales y civiles, y las personas en general tiene, de acuerdo a sus respectivas funciones en la sociedad, obligaciones o responsabilidades respecto a los derechos humanos contenidos en esta Carta" (Carta de la ciudad de México por el derecho a la ciudad, 2009). 


\subsection{8 | Carta-Agenda Mundial de Derechos Humanos en la Ciudad (2011)}

Esta carta-agenda, surge luego de los trabajos iniciados a partir de la Carta Europea de Salvaguarda de los Derechos Humanos en la Ciudad (2000). La diferencia entre esta última y la carta-agenda se encuentra en los alcances geográficos de cada una. Como el mismo nombre lo indica, una de ellas se enfocó en las ciudades europeas, mientras que la Carta-Agenda tiene un alcance mundial, definiendo, además -a diferencia de la primera-, planes de acción e instrumentos de acción para cada uno de los derechos reconocidos, a modo de referencia para los gobiernos locales.

Resulta un documento novedoso ya que se trata de uno de los primeros compromisos de alcance mundial -recordemos que los antecedentes mencionados previamente generaron los primeros instrumentos, debates, discusiones y experiencias, pero en marcos que no traspasaban los límites geográficos propios de cada uno-, entendiendo a la ciudad como el plano en el que se expresan los derechos, deberes y responsabilidades de las personas, superando la concepción meramente territorial de la ciudad, siendo este el punto en el que pueden reconocerse los mayores aportes. La carta define derechos y obligaciones, pero por tratarse de una carta-agenda, sugiere, además, un plan de acción para poder alcanzarlos en el corto y mediano plazo.

Entre los derechos y obligaciones que se definen, el primero corresponde al derecho a la ciudad, entendiendo que todos los habitantes de las ciudades -a quienes define como cualquier persona que viva en un territorio sin importar su condición o si tiene o no un domicilio fijo- "tienen derecho a una ciudad constituida como comunidad política municipal que asegure condiciones adecuadas de vida a todos y todas y que procure la convivencia entre todos sus habitantes y entre estos y la autoridad municipal" (CartaAgenda Mundial de Derechos Humanos en la Ciudad, 2011). Además, en este marco se expone el derecho a participar de los espacios públicos, fundamentales para la convivencia en la ciudad, fomentando el respeto, el pluralismo y la diversidad. Nuevamente, el énfasis está puesto en el ámbito urbano, como aquel en el cual deben concretarse estos derechos, interpretando a las ciudades como las que ofrecen todos los medios disponibles para el ejercicio de los derechos.

Entre las acciones que se sugiere, se encuentra un programa de formación en derechos humanos para los funcionarios municipales reforzando la necesidad del respeto a la diversidad, la convivencia y el bien común. De igual modo, la realización de diagnósticos para evaluar la situación de los derechos humanos en la ciudad, con carácter participativo, para luego desarrollar un plan de acción municipal y también la realización de consultas públicas que permitan la evaluación periódica de los resultados de la carta.

Además, se reconocen otros derechos, como el derecho a la democracia participativa, enfatizando la participación de la ciudadanía -en forma individual o a través de organizaciones de diferentes tipos- en los procesos políticos y de gestión de la ciudad, asegurando la libertad y el acceso a la información necesaria para poder lograrlo. También, el derecho a la paz cívica y a la seguridad -en todas sus dimensiones: física, psíquica, etc.- en la ciudad, dotando a la ciudad de organismos públicos para tal fin; adoptando medidas para disminuir la violencia, particularmente, en la población vulnerable, entre otras cuestiones. Junto a estos, el derecho a la igualdad de mujeres y hombres, sin discriminación de ningún tipo, en todos los ámbitos en los que se desarrollen; y también el derecho de niños y niñas, a condiciones de vida dignas, que permitan su desarrollo. En la misma línea, la libertad de conciencia y religión, opinión e información; y el derecho de reunión, asociación y sindicación, para la protección de sus intereses.

Otros de los derechos que identifica es el acceso a servicios públicos básicos de proximidad, garantizando mínimamente la educación, el acceso a la salud, a la vivienda, a la energía, al agua y el saneamiento y a una alimentación suficiente.

También, derechos culturales, entre los que se encuentran el derecho a una formación y educación, a las prácticas culturales y al deporte, a las artes; y a todo lo necesario para poder concretarlos (espacios para el desarrollo de las actividades, mecanismos, tecnologías, etc.). De modo semejante, el derecho a la 
vivienda y al domicilio, digna, con condiciones de salubridad y en un entorno de centralidad urbana, con seguridad jurídica sobre la misma; así como el derecho al desarrollo urbano y sostenible, de calidad, equilibrado entre todos los barrios.

Finalmente, considera al derecho a la ciudad como aquel que sintetiza todos los demás derechos que la carta comprende, entendiendo que sólo se verá concretado y satisfecho cuando estos se encuentren plenamente garantizados a todos los ciudadanos.

\subsection{9 | Ley 14.449 de Acceso Justo al Hábitat (Argentina, 2012)}

En el año 2012, después de un largo período de disputas y de intereses contrapuestos, se sanciona en Argentina -en la Provincia de Buenos Aires específicamente- la ley de Acceso Justo al Hábitat №14.449 (reglamentada recién un año después), cuyo objeto es "la promoción del derecho a la vivienda y a un hábitat digno y sustentable, conforme lo establece la Constitución de la Provincia de Buenos Aires" (Ley de Acceso Justo al Hábitat, 2013).

Esta ley resulta un avance importante debido a que el instrumento legal más relevante en materia de ordenamiento territorial existente hasta el momento en la Provincia de Buenos Aires era el Decreto-Ley 8912 del año 1977. El mismo, pese al contexto histórico y social en el cual fue concebido, donde gran parte de los Municipios de la Provincia de Buenos Aires habían tenido un crecimiento poblacional importante, con inexistencia de infraestructura básica y con una fuerte demanda de suelo urbano por parte de sectores de bajos ingresos, presentaba potencialidades en relación a las normas que establecía, limitando las construcciones sin servicios básicos (agua de red, pavimentación, desagües cloacales y pluviales y red eléctrica), sosteniendo la necesidad de proveer de servicios y equipamientos a nuevos loteos y planteando una serie de instrumentos destinados a limitar la especulación inmobiliaria que se empezaba a observar en la Provincia (Artículos 15, 17, 56, 62, entre otros). Pese a ello, es una normativa criticada debido a que no generó los efectos esperados, sino que, en ocasiones, los resultados fueron contradictorios y, además, porque muchos de los instrumentos innovadores que se proponían no tuvieron una aplicación plena en el territorio.

Por este motivo -y debido a la complejización de los contextos históricos y económicos-, resultaba importante la sanción de una nueva ley, que complementara y reglamentara cuestiones con mayor profundidad en torno al hábitat. En este sentido, la Ley de Acceso Justo al Hábitat incorpora nuevos principios e instrumentos y apunta principalmente a garantizar derechos a la población más vulnerables (como por ejemplo el derecho a la vivienda, a un ambiente sano, al acceso al suelo, a la urbanización de barrios precarios, entre otros).

Esta ley se vio influenciada por algunos de los instrumentos analizados previamente (el Estatuto de la Ciudad de Brasil, la Ley 388/97 de la República de Colombia, etc.), incorporando la idea de un gobierno democrático del territorio, la necesidad de garantizar el derecho a la ciudad, la función social de la propiedad -sobre este punto se hace gran hincapié, definiendo instrumentos para poder garantizarlo-, el reparto justo de las cargas y los beneficios de la actividad urbanística y la necesidad de desarrollar un urbanismo ambientalmente sostenible.

El artículo $3^{\circ}$ define que "El derecho a una vivienda y a un hábitat digno comporta la satisfacción de las necesidades urbanas y habitacionales de los ciudadanos de la Provincia, especialmente de quienes no logren resolverlas por medio de recursos propios, de forma de favorecer el ejercicio pleno de los derechos fundamentales" (Ley de Acceso Justo al Hábitat, 2013).

En términos del derecho a la ciudad, resulta relevante ya que es uno de los primeros instrumentos jurídicos que lo incorpora en la República Argentina. Inicialmente, la ley entiende que el problema que debe resolverse es el del hábitat en términos integrales, explicitando en el artículo 4 que "A los fines de esta Ley, se denomina déficit urbano habitacional a la escasez, calidad insuficiente o inaccesibilidad a condiciones materiales, servicios y espacios aptos para satisfacer las necesidades y promover una mejor calidad de 
vida de la población en el marco de un hábitat ambientalmente sostenible" (Ley de Acceso Justo al Hábitat, 2013).

Conjuntamente, enfatizando aún más la necesidad de garantizar aspectos integrales, el artículo 11 de la ley define que "Todos los habitantes de la Provincia tienen garantizado el derecho al uso y goce de la ciudad y de la vivienda, entendiendo a éstos como el derecho a: a) Un lugar adecuado para vivir en condiciones que favorezcan la integración plena a la vida urbana. b) Acceder a los equipamientos sociales, a las infraestructuras y a los servicios. c) Desenvolver apropiadamente las actividades sociales y económicas. d) Usufructuar de un hábitat culturalmente rico y diversificado" (Ley de Acceso Justo al Hábitat, 2013).

Esto se complementa con el artículo 15 en el que se definen los parámetros de calidad y hábitat dignos, entendiendo que deben contemplarse aspectos de localización (cercanía a las áreas de centralidad, accesibilidad y conectividad, consolidación urbana, cobertura de servicios y acceso a equipamientos urbanos básicos), niveles de habitabilidad de la vivienda, calidad del espacio público y acceso a servicios básicos, integración con áreas circundantes, diseño edilicio bajo pautas de eficiencia y ahorro energético, entre otras cuestiones. Sin embargo, se definen estos parámetros sólo para los proyectos de urbanización por parte del Estado, sin contemplar a la totalidad de la población.

En síntesis, la ley explicita en qué consiste el derecho a la vivienda y a un hábitat digno, definiendo además obligaciones para las instancias Estatales, reglamentando y desarrollando, a tal fin, una serie de instrumentos para garantizar su efectiva aplicación.

\section{2 | El derecho a la ciudad hoy. ¿Es posible pensar este derecho en la ciudad actual?}

Los contextos actuales se han modificado y, conjuntamente, las aproximaciones en torno al derecho a la ciudad. Lorena Zárate (2011) describe a las ciudades actuales -particularmente las ciudades latinoamericanas- como ciudades en crecimiento, con procesos de urbanización acelerados, ciudades duales y con procesos de segregación acentuados y en las que se observa una concentración de poder económico. Frente a este panorama, resalta las luchas que existen por revertir o mejorar estas situaciones en el marco del derecho a la ciudad, rescatando de estas experiencias los logros alcanzados a diferentes escalas (principalmente normativas y declaraciones) y en diferentes contextos.

Jane Jacobs, ya en los años '60 manifestaba los grandes efectos de las políticas urbanas en la ciudad de Nueva York, aunque bien podrían referirse, años más tarde, a nuestras ciudades:

"Pero veamos lo que hemos construido con los primeros miles de millones: barrios de viviendas baratas que se han vuelto peores centros de delincuencia, vandalismo y desesperanza social que los barrios bajos que iban a sustituir. Promociones de viviendas de renta media, auténticos milagros de monotonía y regimentación, que se han parapetado contra la vitalidad y exuberancia de la vida ciudadana. Barrios residenciales de lujo que mitigan su inanidad, o eso intentan, mediante una insulsa vulgaridad. Centros culturales que no pueden albergar una buena librería. Centros cívicos que sólo frecuentan los indigentes, los que no pueden elegir sus lugares de esparcimiento. Centros comerciales que son una imitación sin lustre de los de las avenidas comerciales al uso, plagadas de franquicias. Paseos que van de ningún sitio a ninguna parte y que no tienen paseantes. Vías rápidas que destripan las grandes ciudades... Esto no es reordenar las ciudades. Esto es saquearlas" (Jacobs, 2011).

Con respecto a estas problemáticas en nuestro país específicamente, existen muchos autores que han estudiado sus causas y efectos, coincidiendo en que, a pesar de que existen mejoras en términos socioeconómicos a nivel nacional, la problemática habitacional en relación a las condiciones del hábitat, se ha agravado (Cravino, 2012; Fernández Wagner, 2006; Catenazzi y Reese, 2010). 
Es así que estos nuevos contextos conducen a repensar el derecho a la ciudad, con una mirada desde la complejidad que este implica. David Harvey (2012), es uno de los autores que retoma estos conceptos y, al igual que Lefebvre, considera que el derecho a la ciudad es mucho más que el acceso individual o colectivo a los recursos urbanos, refiriendo además a la posibilidad de cambiar, reinventar, transformar las ciudades de acuerdo a los deseos de la población; constituyéndose, por lo tanto, en un poder colectivo sobre los procesos de urbanización y planificación de nuestras ciudades.

En esta línea, se destaca el libro "Revolución urbana y derechos ciudadanos" de Jordi Borja (2014) quien refiere a los problemas de la ciudad relacionados, entre otros, a la precariedad del trabajo, a las dificultades en el acceso a la vivienda y el suelo urbano, a las deficiencias de las infraestructuras de movilidad y los servicios públicos y también, al rol de las políticas en relación a éstos en el marco de la democracia. Afirma, entonces, que una de las posibles estrategias de trabajo es repensar los derechos ciudadanos a través del derecho a la ciudad que integra múltiples consideraciones relacionadas a las problemáticas a las cuales se refiere previamente.

A pesar de que son muchos los autores que definen el derecho a la ciudad, se destaca a Borja ya que hace énfasis en comprender que este implica mucho más que la simple suma de derechos relacionados al entorno físico, sino que incluye, además, derechos políticos y sociales, que conforman la ciudadanía; detallando en qué consiste cada uno.

\section{3 | El derecho a la ciudad como "herramienta"}

En relación a la necesidad de incorporar el derecho a la ciudad como herramienta, Enrique Ortiz Flores (2006) recalca el proceso de construcción que ha tenido este derecho en contextos latinoamericanos; y, particularmente, el proceso a través del cual pudo construirse un instrumento fundamental como es la Carta Mundial del Derecho a la Ciudad. Así, afirma que "el derecho a la ciudad es interdependiente de todos los derechos reconocidos, concebidos integralmente, y está abierto a incorporar nuevos derechos (...) Implica el derecho a construir y hacer ciudad, el derecho al lugar, a permanecer en él y a la movilidad; al agua y la alimentación, la vivienda, los servicios públicos y el uso democrático de los espacios públicos; a la salud, la educación y la cultura; al desarrollo y a un medio ambiente sano" (Ortiz Flores, 2006), entre otros.

Jordi Borja (2014) plantea también, que el desarrollo y legitimación de los derechos ciudadanos dependerá de que se desarrolle un triple proceso:

- Un proceso cultural, de hegemonía de los valores que están en la base de estos derechos y explicitación de los mismos;

- Un proceso social, de movilización de los propios ciudadanos para conseguir su legalización y la creación de mecanismos, herramientas y demás que permitan concretarlos;

- Un proceso político-institucional para formalizarlos, consolidarlos y desarrollar las políticas para hacerlos efectivos

En esta misma línea, la red de organizaciones Hábitat International Coalition posee múltiples documentos en los que se destaca la necesidad de incorporar el derecho a la ciudad en el desarrollo de políticas, instrumentos y herramientas de planeamiento. Uno de ellos es el denominado "Ciudades para todos. Por el derecho a la ciudad, propuestas y experiencias" de Ana Sugranyes y Charlotte Mathivet (2010), en el que se hace eje en diferentes experiencias de derecho a la ciudad y se pretende resaltar la "fortaleza del derecho a la ciudad como herramienta para una ciudad y, por tanto, un mundo mejor".

Las experiencias que en este libro se describen se relacionan -entre otras cuestiones- con luchas populares en torno tanto a la satisfacción de derechos contemplados en el derecho a la ciudad; como a la resistencia a la vulneración de los mismos. 
En relación a las primeras, se describe, por ejemplo, el movimiento de los Sin Techo en la ciudad de Mar del Plata, Argentina, que se constituyó a fin de garantizar el derecho a la vivienda para un conjunto de familias en situación de emergencia habitacional. Se trató de un proceso complejo, que se inició con la construcción de una serie de viviendas por parte del Estado, a través del Subprograma Bonaerense " $X$ Dignidad", a fin de trasladar a los habitantes de sus viviendas precarias e insalubres. Sin embargo, el proyecto se paralizó y la totalidad de las viviendas no fueron entregadas a los destinatarios. Los vecinos, en busca de satisfacer su derecho a la vivienda, decidieron colectivamente recuperar este predio y finalizar la construcción de las viviendas por sus propios medios; "en otras palabras, la recuperación de este espacio trascendía el inmediato derecho a la vivienda, y bregaba por el derecho a la ciudad, en el sentido que rescataba el valor de uso del espacio; primaba la apropiación por sobre la dominación, como propone Lefebvre. Era la reconstitución de un conjunto de derechos inalienables: la vivienda, la salud, la educación" (Nuñez, 2010)

En relación a las segundas, se describen procesos de protesta frente a situaciones que vulneran el derecho a la ciudad. A modo de ejemplo, uno de los casos estudiados es el de Villa Los Cóndores en Temuco, Chile, un conjunto de viviendas para 900 familias aproximadamente, financiadas por el Estado a partir de políticas para la reducción del déficit habitacional. En el proceso de construcción de estas viviendas no se contemplaron estándares mínimos de habitabilidad, lo que dio como resultado viviendas de baja calidad e incluso peligrosas para sus habitantes. Frente a esta situación, y a los reclamos de los habitantes, la Cámara de Diputados del Congreso Nacional dictaminó la destrucción del complejo. Esta situación implicaba, entonces, el desalojo de las familias que lo habitaban; familias que ya se habían constituido como propietarios formales y legales de sus viviendas, derivando en múltiples reacciones por parte de los habitantes. Una de ellas fue la reivindicación de su derecho a habitar en ese espacio, exigiendo la reconstrucción de sus viviendas, lo que condujo a la organización de los vecinos para la creación de Comités de Vivienda, que empezaron a asociarse a otras organizaciones e instituciones a fin de garantizar este derecho. Pese a que estos procesos son lentos, los vecinos han alcanzado algunos logros tendientes a mejorar su condición de habitabilidad y a visibilizar cada vez más sus reclamos; transformando a este caso en un ejemplo de aplicación y reivindicación del derecho a la ciudad.

Sin embargo, en términos de antecedentes técnico-metodológicos de aplicación e implementación del derecho a la ciudad, fue limitado el reconocimiento de referentes. Fernando Murillo y Mariana Schweitzer en "La planificación urbana habitacional y el derecho a la ciudad. Entre el accionar del Estado, el mercado y la informalidad" (2010), desarrollan una metodología para generar un "Indicador de Derecho a la Ciudad", planteando, entre otras cuestiones, que el derecho a la ciudad depende principalmente de mejores regulaciones del desarrollo urbano. En este caso, el derecho a la ciudad es entendido como "la posibilidad de los sectores populares de acceder a una vivienda y servicios urbanos básicos a precios acordes a sus posibilidades y necesidades" (Murillo, Schweitzer, 2010).

El trabajo evalúa cuatro casos de estudio (Villa Soldati, Villa Zagala, el barrio San Carlos y el barrio Padre Varela en Moreno); a partir de indicadores relacionados a: Calidad de la Infraestructura (agua, saneamiento, energía, etc. a nivel urbano), Calidad de la Vivienda (materiales de construcción, servicios a nivel domiciliario) y Situación habitacional (tenencia de suelo y hacinamiento). Así, combinando los indicadores, se procura ilustrar un indicador de cumplimiento de derecho a la ciudad que puede dar cuenta de aquellos factores que influyen en la generación de condiciones habitacionales inaceptables y de negación de acceso a los servicios urbanos más básicos.

En esta línea, pese a que se enfoca el análisis en una serie de variables fundamentales para el derecho a la ciudad, el recorrido teórico conceptual desarrollado permitió reconocer que este derecho implica otra multiplicidad de variables. Sin embargo, resulta un antecedente relevante para el desarrollo de la presente investigación ya que incorpora el derecho a la ciudad como un enfoque a partir del cual realizar una evaluación mediante la definición de variables e indicadores. 


\section{4 | Consideraciones generales}

En síntesis, este breve recorrido permitió reconocer la existencia de múltiples cartas y documentos teóricos en torno al derecho a la ciudad, particularmente en Latinoamérica. Sin embargo, solo algunos de estos ejemplos derivaron en instrumentos legales ya que la firma de los mismos no implicó una obligación de su concreción, corriendo el riesgo de que se transformen en meras declaraciones de intenciones. A pesar de esto, cada una de las manifestaciones en torno al derecho a la ciudad, particularmente aquellas de las que participan los gobernantes, empiezan a posicionar a este enfoque como una alternativa posible para generar cambios en torno a una búsqueda de la mejora de la calidad de vida de los habitantes.

Como resultado, el estudio del estado de la cuestión y la búsqueda de referentes, permitió determinar la existencia de un campo teórico importante en relación a las temáticas y conceptos relevantes para el desarrollo de la presente investigación, fundamentalmente en torno al derecho a la ciudad y lo que éste implica; y, por el contrario, las limitaciones en términos de referentes metodológicos de aplicación e implementación del derecho a la ciudad como mecanismo de evaluación y propuesta.

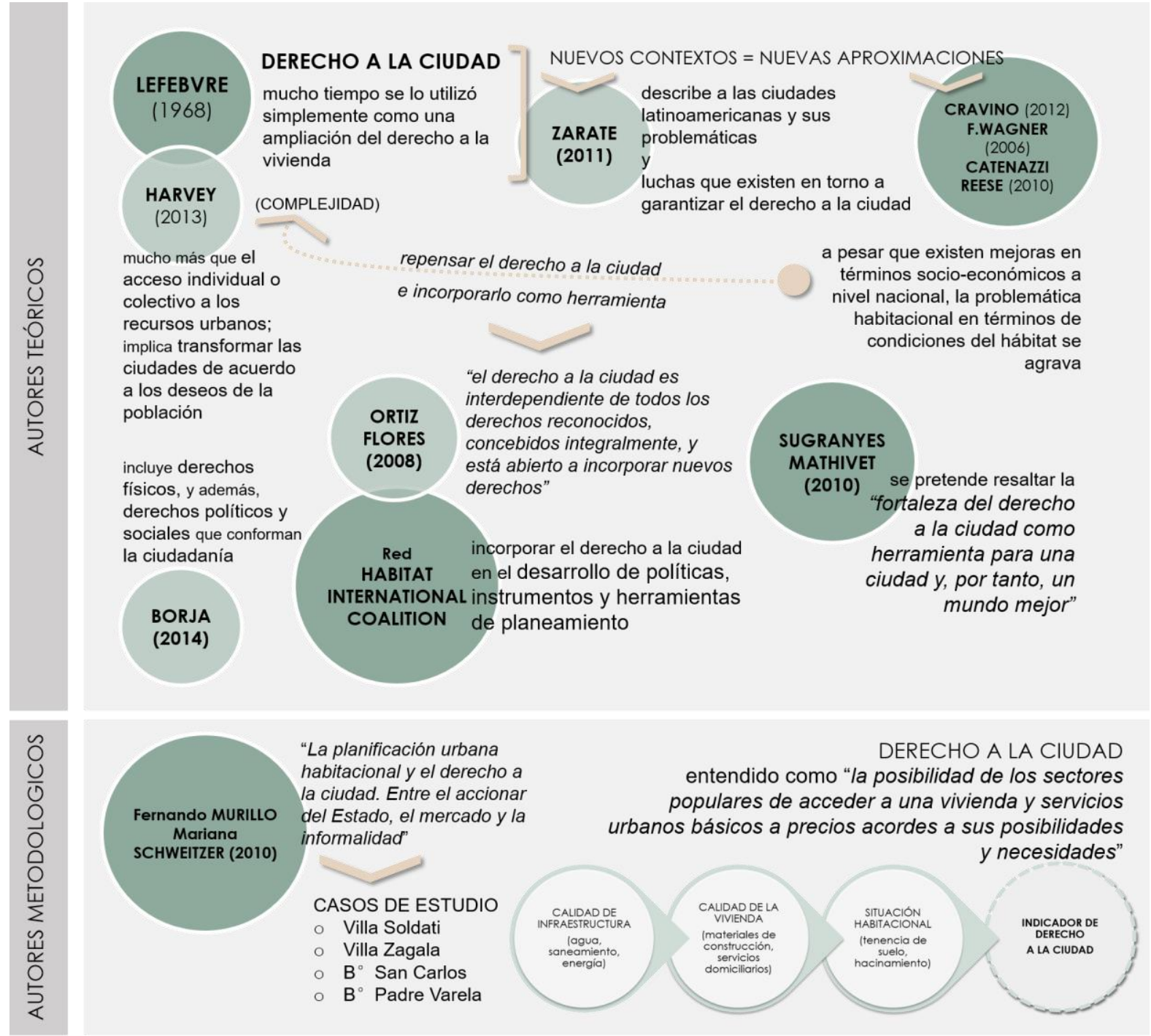

Figura 5. Referentes teóricos y metodológicos analizados. Elaboración propia. 2019 


\section{CAPÍTULO 2 | MARCO TEÓRICO. CIUDAD, DERECHO Y HÁBITAT}

"El Derecho a la Ciudad implica la búsqueda de una gestión urbana democrática e incluyente en la que no sólo decidan qué hacer en ella el capital inmobiliario y el gobierno, sino también quienes la habitan, trabajan y/o disfrutan de la ciudad"

(Carrión, F.; Erazo, J.; 2016)

En este capítulo se analizaron referentes teóricos y se realizaron precisiones conceptuales en torno al derecho a la ciudad articuladamente, definiendo el conjunto de conceptos teóricos-metodológicos que determinan el modo de observar la realidad.

La elección del enfoque del derecho a la ciudad no es arbitraria, sino que encuentra su fundamento en las características de la ciudad actual, en la que las instancias de gobierno reconocen multiplicidad de derechos a sus habitantes, que aparecen como una novedad política pero no tienen suficiente arraigo institucional ni cultural. Así, el derecho a la ciudad surge como un enfoque superador y provocador, como una posibilidad de construir una nueva ciudad; y como una propuesta de cambio ante las problemáticas generadas por el modelo económico-político actual.

\section{1 | EL ESPACIO Y EL TERRITORIO. El territorio como espacio social urbano}

El mundo actual, como se ha expresado en el capítulo anterior, es un mundo urbano. El espacio se ha vuelto un espacio urbano, ya que "la ciudad ha vencido" (Corboz 2004); entendiendo que no es aquel en que las construcciones se suceden de manera compacta, sino aquel en que los habitantes adquieren una mentalidad urbana. Por eso, Corboz afirma que el territorio constituye en la actualidad la unidad de medida de los fenómenos humanos, definiéndolo a partir de tres aspectos:

- el "territorio como proceso", resultado de acciones múltiples que provocan que esté en constante modificación, sufriendo no sólo los cambios que se producen espontáneamente sobre la morfología terrestre, sino también las intervenciones urbanas;

- el "territorio como proyecto", debido a que en el momento en que la sociedad comienza a habitar un territorio, establece con él una relación, comienza a construirlo, a discutir sobre él, definiendo objetivos y medios para su uso;

- el "territorio como palimpsesto"; entendiendo que las actividades del hombre y los diversos procesos territoriales acontecidos a lo largo de la historia, imprimen "marcas" que hacen único a cada territorio.

Este último concepto de "territorio como palimpsesto", refuerza la noción de que cada territorio es especial, posee características particulares y, por tanto, debe analizarse en profundidad, encontrando las necesidades específicas que tiene y, consecuentemente, la población que lo habita.

En concordancia con Corboz, la geógrafa Claudia Tomadoni (2007) sostiene que el espacio geográfico se define como "naturaleza y sociedad". El espacio se refiere a ámbitos genéricos construidos por la sociedad, que se concretan en un territorio. Así, sostiene que el territorio conforma un lugar preciso, con límites y características específicas que también responden a los agentes sociales que construyen ese territorio; una construcción social en determinadas coordenadas de tiempo y lugar que aglutina objetos de diferente naturaleza, otorgando forma a un paisaje que adquiere toda su dinámica en la relación con su contenido, es decir, con la sociedad que le da sentido y significado. 
Además, añade a estas definiciones la idea de que el territorio constituye un conjunto de relaciones complejas en la dimensión espacio-tiempo, entendiendo que debe superarse la idea de que existen dos escalas separadas, el espacio y el tiempo, y comprender que deben adoptarse como una sola dimensión en las que ambas unidades se influencian mutuamente.

Por ello es claro que puede entenderse al territorio como un espacio social y urbano -ya decía Lefevbre hace décadas, que todos somos "seres urbanos"-, en el que los actores sociales cumplen roles diferentes y en el que el hombre adquiere una importancia relevante, como parte constituyente del territorio, entendiendo que se verá afectado directa o indirectamente por las intervenciones que se dan dentro del mismo.

\section{2 | DERECHO y CIUDAD. La ciudad como espacio de realización de derechos}

En concordancia con los núcleos conceptuales planteados hasta aquí, la ciudad puede definirse como la articulación entre tres componentes principales: la "urbs", la "civis" y la "polis" (López, 2003). La "urbs" se constituye a partir de los elementos materiales que conforman a la ciudad -la expresión física de la ciudad, es decir, lo construido-. La "civis", se conforma por la sociedad -la comunidad humana de grupos sociales e institucionales-, con sus pautas culturales y sociales que otorgan identidad y la transforman en compleja. Y, finalmente, la "polis" que constituye el sentido político y de gobierno del asentamiento.

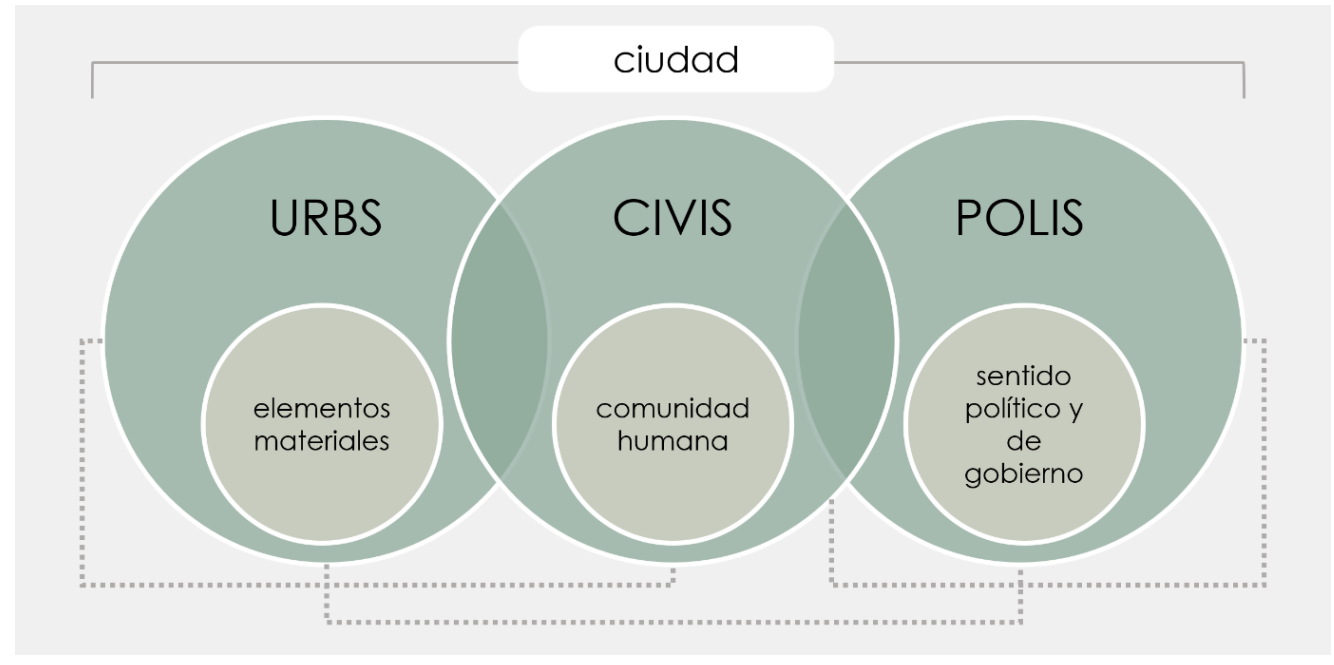

Figura 6. Representación gráfica del concepto de "ciudad". Componentes Principales. Elaboración propia en base a López. 2003

De esta forma, la sociedad se expresa en las ciudades, participando de los procesos de construcción material de las mismas y de las instancias de toma de decisiones, transformando a las ciudades en medios para la construcción social y la defensa de derechos.

Lo estudiado hasta el momento, pone en el centro del debate los derechos de las personas a la ciudad así como a sus responsabilidades-. En este sentido, según lo analizado en el capítulo anterior, la CartaAgenda Mundial de los Derechos Humanos en la Ciudad (2011) define claramente estas relaciones, entendiendo que "...la ciudad es una comunidad política en la que todos sus habitantes participan en un proyecto común de libertad, de igualdad de derechos entre hombres y mujeres en la diversidad y de desarrollo individual y colectivo (...)" y "...la ciudadanía, con sus derechos, deberes y responsabilidades, se expresa especialmente en el plano de la ciudad".

De esta forma, y adoptando las definiciones que se encuentran en este antecedente, puede articularse otro de los pares conceptuales que guían el presente trabajo -derecho y ciudad-, e interpretar a la ciudad como un espacio de realización de derechos. 


\section{3 | DERECHO A LA CIUDAD y HÁBITAT. La complejización del concepto}

El par conformado por conceptos complejos como son: el "derecho a la ciudad" y "hábitat" representa una oportunidad de reflexión muy interesante, ya que muy pocas veces puede referirse a uno de ellos sin hacer referencia al otro.

En relación al primero, tiene sus antecedentes iniciales en un libro del año 1968 de Lefebvre, en el que se analizaban los impactos negativos que habían sido generados en las ciudades capitalistas, a partir de la transformación de la ciudad en una mercancía al servicio exclusivo de los intereses de la acumulación de capital. Frente a este contexto, Lefebvre plantea una propuesta que parte de la concepción de que la gente volviera a ser "dueña" de la ciudad, proponiendo "rescatar al ciudadano como elemento principal, protagonista de la ciudad que él mismo ha construido" (Lefevbre, 1974) y dejando de actuar como simples espectadores, comenzar a participar en los procesos de desarrollo y construcción de las ciudades, definiendo una reivindicación social.

Este enfoque es sobre el cual se apoya la presente investigación, entendiendo por "derecho a la ciudad" al usufructo equitativo de las ciudades dentro de los principios de sustentabilidad ${ }^{7}$ y justicia social ${ }^{8}$. Se entiende como un "derecho colectivo de los habitantes de las ciudades, en especial de los grupos empobrecidos vulnerables y desfavorecidos, que les confiere la legitimidad de acción y de organización, basado en sus usos y costumbres, con el objetivo de alcanzar el pleno ejercicio del derecho a un patrón de vida adecuado" (Carta Mundial del Derecho a la Ciudad, 2004).

Los principios fundamentales de este derecho tienen que ver con:

- generar una gestión democrática de la ciudad, en la que cada habitante pueda participar de los procesos de toma de decisiones, a partir de un ejercicio pleno de la ciudadanía, promoviendo una planificación participativa de las ciudades;

- fomentar el usufructo equitativo de las ciudades, es decir, que todos los habitantes puedan hacer uso y gozar de los recursos que estas ofrecen;

- promover el acceso a servicios básicos como el transporte público, la educación, la salud, la cultura y, fundamentalmente, a una vivienda digna;

- el respeto por el medio ambiente, a partir de procesos ordenados de ocupación del territorio, protegiendo áreas ambientalmente vulnerables y recursos fundamentales para la vida;

- y garantizar la igualdad de todos los habitantes, sin discriminación de ningún tipo, comprendiendo que "la ciudad es el lugar donde se entremezcla gente de todo tipo y condición, incluso contra su voluntad o con intereses opuestos, compartiendo una vida en común, por efímera y cambiante que sea" (Harvey, 2012).

\footnotetext{
${ }^{7}$ La sustentabilidad es entendida desde la visión de Claudia Tomadoni (2007) quien sostiene que ésta supone el uso de los recursos naturales sin agotarlos en el tiempo presente para preservar la naturaleza para las generaciones actuales y las generaciones futuras. Así la noción se compone de tres dimensiones:

- la temporal: implica mantener dando permanencia en el tiempo;

- la espacial: involucra mantener los recursos de la naturaleza de un determinado lugar;

- la social: supone mantener para las sociedades del futuro.

${ }^{8}$ El concepto de justicia social tiene múltiples definiciones. Sin embargo, para esta investigación, se adopta la visión de Méndez Nuñez y Murillo (2017) quienes entienden que la justicia social puede definirse como una conjugación de tres aspectos:

- Redistribución (justicia como equidad), es decir, que las instituciones brinden tratos diferenciados a cada individuo para compensar por las desigualdades que generan las estructuras sociales (cuestiones de clase, de género, de origen, de cultura, entre otras);

- Reconocimiento (justicia cultural), fomentando la ausencia de dominación cultural y el respeto y la valoración de las diferencias sociales y culturales;

- Representación (justicia como participación), promoviendo el acceso y la equidad, así como las condiciones necesarias para asegurar la plena participación de las personas en la vida social, especialmente para la población excluida.
} 


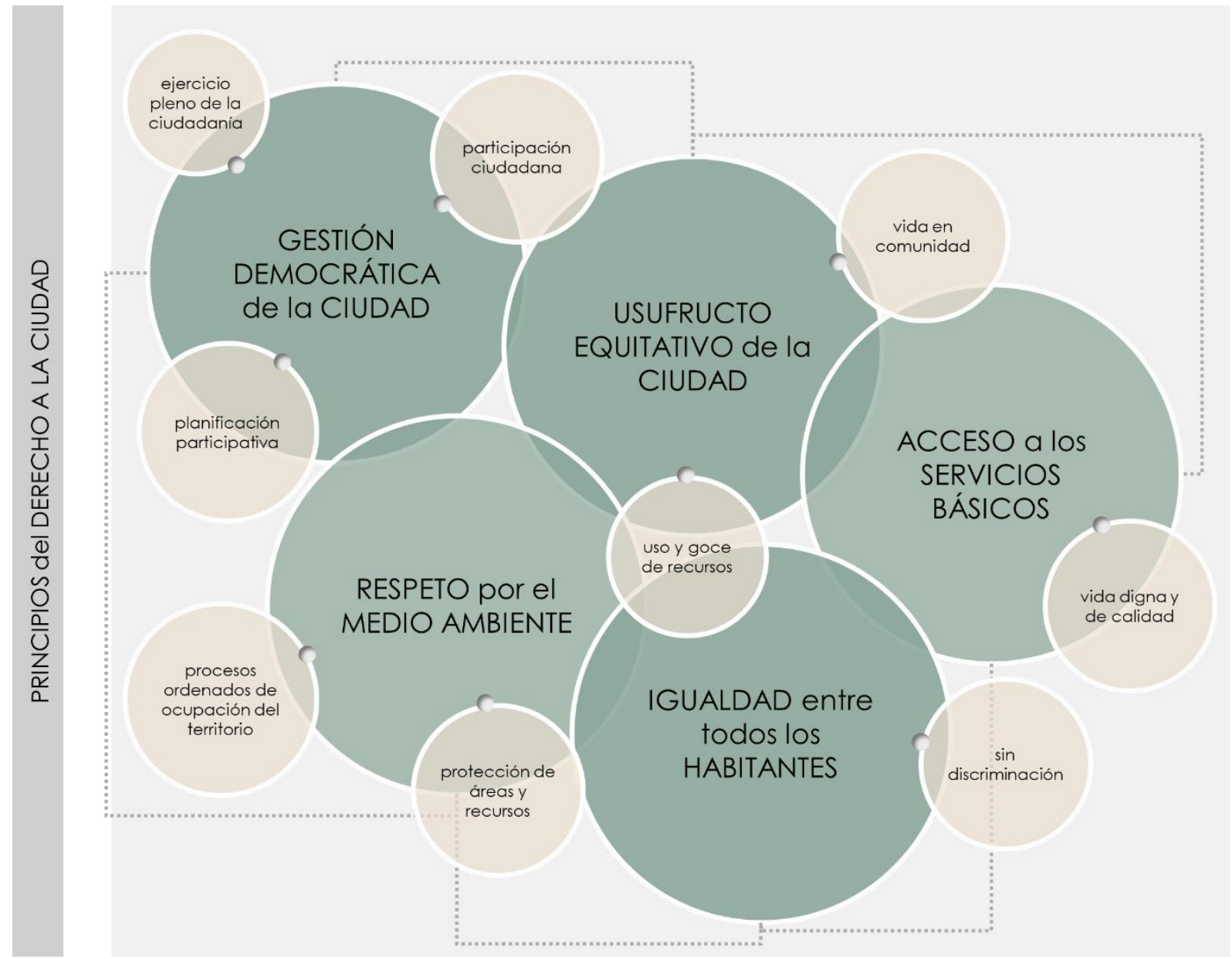

Figura 7. Principios del derecho a la ciudad. Elaboración propia en base a CARTA MUNDIAL DE DERECHO A LA CIUDAD. 2014

La Carta Mundial del Derecho a la Ciudad se alimenta del concepto de Lefebvre, manifestando que los derechos básicos que deben satisfacerse son aquellos relativos a la gestión de la ciudad (desarrollo urbano, transparencia en la gestión, derecho a la participación, etc.), derechos civiles y políticos de la ciudad (libertad e integridad, derecho a la justicia, entre otros) y derechos económicos, sociales, culturales y ambientales de las ciudades, como son el acceso y suministro de servicios públicos domiciliarios y urbanos y el derecho al transporte y movilidad públicos. También resulta fundamental el derecho a una vivienda, pero una que "reúna condiciones de habitabilidad, estén ubicadas en un lugar adecuado y se adapten a las características culturales y étnicas de quienes las habitan" (Carta Mundial de Derecho a la Ciudad, 2014).

El concepto de hábitat complementa el del derecho a la ciudad, entendiendo que el "hábitat" debe permitir "habitar" y que esto implica mucho más que simplemente radicarse u ocupar un lugar, sino que, además, el hombre debe identificarse con ese lugar, hacerlo propio, pertenecer a él y, en consecuencia, el simple hecho de tener un techo no significa habitar -"Pues cómo se puede habitar si se tiene un techo pero debajo del cual se vive hacinado, sin empleo, sin acceso a la educación, la salud, con dificultades para poderse desplazar a otros sectores"(Chardón, 2010)-. Así, el derecho a la ciudad entendido como una conjunción de derechos que exceden el simple hecho de tener una vivienda, se encuentra íntimamente relacionado al concepto de hábitat y de habitar, y con las problemáticas que existen en torno a él (exclusión, segregación, ocupación de áreas de riesgo, entre otros). 
En concordancia con el concepto de "habitar", Jordi Borja (2014) reflexiona acerca de cómo el derecho a la ciudad implica no sólo el acceso a una vivienda, sino también a un lugar y a la apropiación de este lugar: "la gente tiene derecho a mantener su residencia en el lugar donde tiene sus relaciones sociales, sus entornos significantes". En relación a esto, define al "espacio público como factor de redistribución social (...) igualitario e integrador (...). Los elementos de monumentalidad le dan visibilidad e identidad". Indica también el derecho a la belleza: "como prueba de la calidad urbana y de reconocimiento de una necesidad social". Plantea también el derecho a la movilidad y a la accesibilidad (derecho al transporte y la movilidad públicos), que permita igualar las condiciones de acceso a las centralidades y la movilidad desde cada zona de la ciudad. Por último, refiere también al medio ambiente como un derecho a la calidad de este medio.

Como plantea Harvey (2008), "el derecho a la ciudad es mucho más que la libertad individual de acceder a los recursos urbanos: se trata del derecho a cambiarnos a nosotros mismos cambiando la ciudad". Por eso, sostiene que más que un derecho individual, constituye un derecho común y que, en consecuencia, es necesario un esfuerzo colectivo para generar las transformaciones sobre la ciudad. Por este motivo, se comparte la concepción de que resulta fundamental entender que el derecho a la ciudad "implica un proceso de construcción de conocimiento sobre la ciudad y también una búsqueda relacionada con la lucha social por el desarrollo de ciudades más justas y equitativas" (Fernández Wagner, 2014). Desde esta perspectiva, se entiende que la ciudad es una producción social, una construcción colectiva entre diferentes actores que son las unidades reales de acción en la sociedad, tomadores y ejecutores de decisiones (Pirez, 1995).

Surge entonces el interrogante de cómo se construyen las ciudades y quienes son los actores que participan en estos procesos. En el caso de Latinoamérica en general, la construcción de las ciudades se da a partir de dos procesos que ocurren en forma continua y simultánea: la acción del mercado y la acción del Estado; sumando un tercer actor fundamental que es la sociedad que habita, construye y modifica las ciudades. Como manifiesta Perceval (2011), "el espacio también es una producción social, que no es neutral y que debe ser analizado considerando los diferentes actores y funciones que participan en la creación de la vida cotidiana".

Así, la ciudad construida por el mercado es aquella que surge del resultado de las relaciones de competencia entre múltiples actores que buscan satisfacer necesidades o alcanzar algún tipo de beneficio económico. En principio, entonces, puede definirse al mercado como "toda institución social en la que los bienes y servicios, así como los factores productivos, se intercambian libremente" (Mochón, 1997). Esto implica la existencia de agentes que se dedican a la oferta de estos bienes y servicios y otros relacionados a la demanda de los mismos. Por ende, la interacción que se da entre ambos -oferta y demandadetermina los precios de los bienes y servicios.

El Estado participa en la construcción de la ciudad y del hábitat actuando de diferentes maneras. Jaramillo (2003) identifica cuatro roles diferentes. En principio, el Estado como "productor de espacio construido", que produce inmuebles de diferentes tipos: espacios de uso colectivo (como centros culturales, escuelas, hospitales, entre otros), espacios de uso propiamente del Estado (oficinas administrativas y de gobierno, etc.) y espacios destinados al uso privado (como son las viviendas de carácter social). En este contexto, el Estado también se reconoce como "suministrador de equipamiento", proveyendo infraestructura urbana (vías de circulación, equipamientos, entre otros) y generando impactos sobre el valor del suelo y la posibilidad de acceso al mismo debido a las transformaciones que estas intervenciones generan sobre las pautas de utilización del espacio urbano. En cuanto a este último aspecto, se observa que, muchas veces, las inversiones del Estado en materia de infraestructuras y equipamientos no son homogéneas con respecto a la totalidad del área urbana, ya que muchas veces se valorizan las áreas que condensan mayor población que, en general, pueden afrontar los gastos de infraestructura y servicios. En esta línea, también refiere al Estado como "agente fiscal", utilizando herramientas como los impuestos y gravámenes a los terrenos urbanos y otros servicios, también generando modificaciones sobre el espacio urbano. 
Finalmente, otro de los roles que identifica es el del Estado como "regulador de los usos del suelo en la ciudad", teniendo como objetivo la búsqueda de coherencia, equidad, eficiencia, entre otros, y buscando, principalmente, actuar sobre los efectos negativos que genera la acción del mercado; a partir de una reglamentación no solo de usos sino también de densidades del suelo.

Desde esta perspectiva, las políticas públicas ocupan un espacio destacado en la compleja articulación entre el Estado y la sociedad. Oszlak y O'Donnell (1981), las definen como un conjunto de acciones y omisiones que manifiestan una determinada modalidad de intervención del Estado en relación con una cuestión que concita la atención, interés o movilización de otros actores en la sociedad.

Sin embargo, en estos contextos neoliberales, en que el énfasis está puesto en la búsqueda de ganancia, en la exaltación de la propiedad privada y en el individualismo, las ciudades se transforman en injustas, "como una maquinaria que bajo formas legales excluye, segrega, fragmenta y oprime mediante las relaciones mercantiles"; y en la que "Ios inalienables derechos de la propiedad privada y la tasa de ganancia se sobreponen por sobre cualquier otro tipo de derechos que podrían concebirse como inalienables" (Fernández Wagner, 2014); generando cada vez mayores desigualdades en el acceso al trabajo y a la educación, a la salud, al ambiente, a los recursos, entre otros - en contraposición a los derechos que la ciudad debe garantizar-. Harvey (2008) plantea también esta concepción de la ciudad injusta, entendiendo que es una condición intrínseca a las ciudades del sistema capitalista, un sistema injusto en sí mismo.

\section{4 | Consideraciones generales}

A modo de síntesis, el análisis de referentes teóricos permite observar que el derecho a la ciudad resulta un concepto complejo, integrador de múltiples aspectos que aspiran a mejorar la calidad de vida de la población y, en este marco, pueden reconocerse una serie de líneas generales que abordan este concepto de diferentes maneras, complementarias unas de otras.

En principio, el derecho a la ciudad como posibilidad de una ciudad diferente, que permita modificar situaciones problemáticas que se evidencian en los contextos actuales. En este punto, encontramos autores como Lefebvre y Borja, quienes interpretan que la ciudad debe dejar de ser el lugar conflictivo y problemático para convertirse en un lugar que permita el desarrollo de una vida digna, ya que es la propia ciudad la que ofrece las condiciones que deberían permitir a los ciudadanos alcanzar este estado.

En concordancia con esto, encontramos otros autores que complementan esta concepción con la consideración del derecho a la ciudad como un derecho colectivo. El antecedente más representativo se encuentra en la "Carta Mundial por el Derecho a la Ciudad", presentando derechos referidos al colectivo de los ciudadanos y al contexto urbano; entendiendo que la función principal de la ciudad es de tipo social e implica garantizar derechos a todos los habitantes por igual, permitiendo el usufructo equitativo de las ciudades.

Además, la consideración del derecho a la ciudad como derecho complejo, con representantes en autores como Harvey, con una necesaria complementariedad con posturas como las de Fernández Wagner, que manifiestan la necesidad de generar conocimiento acerca de la ciudad, para poder intervenir sobre ellas, garantizando este derecho y generando ciudades más justas y equitativas.

En conclusión, en este contexto de países con sistemas neoliberales que expulsan y excluyen a la población de derechos como el empleo, el salario digno, un hábitat en condiciones adecuadas, puede entenderse que el derecho a la ciudad propone nuevos derechos colectivos que exceden la individualidad -enfatizando los aspectos sociales-, como mecanismo de superación de los efectos generados por estos sistemas; buscando conquistar derechos colectivamente, para poder disfrutarlos luego de forma individual. 

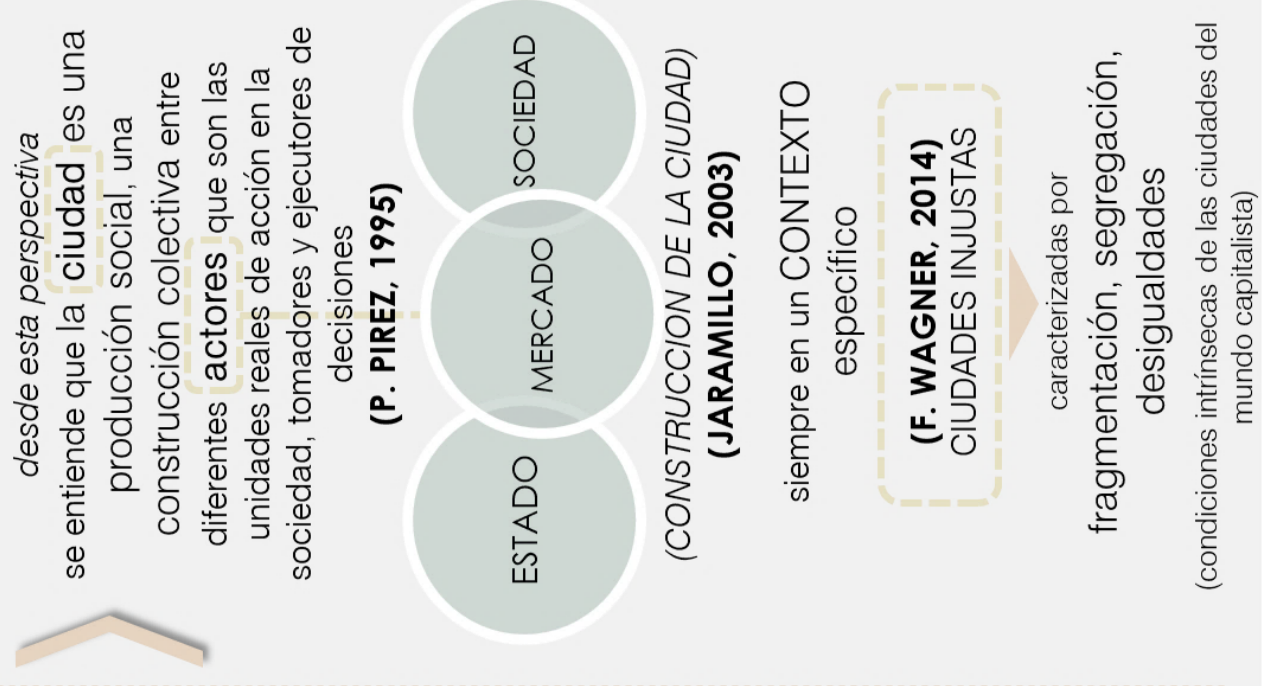

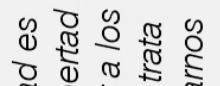

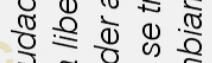

क力

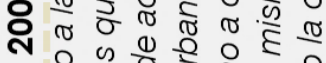

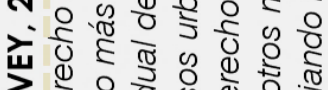

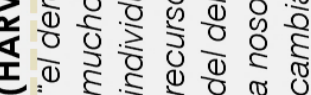

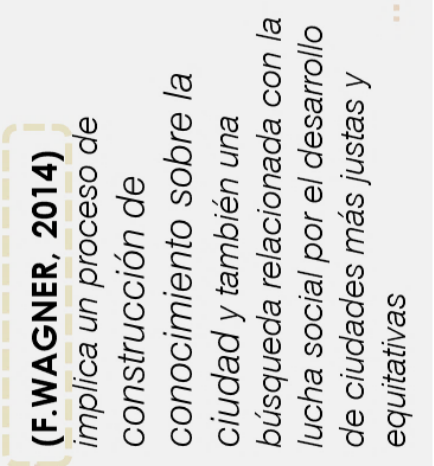

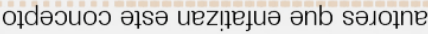

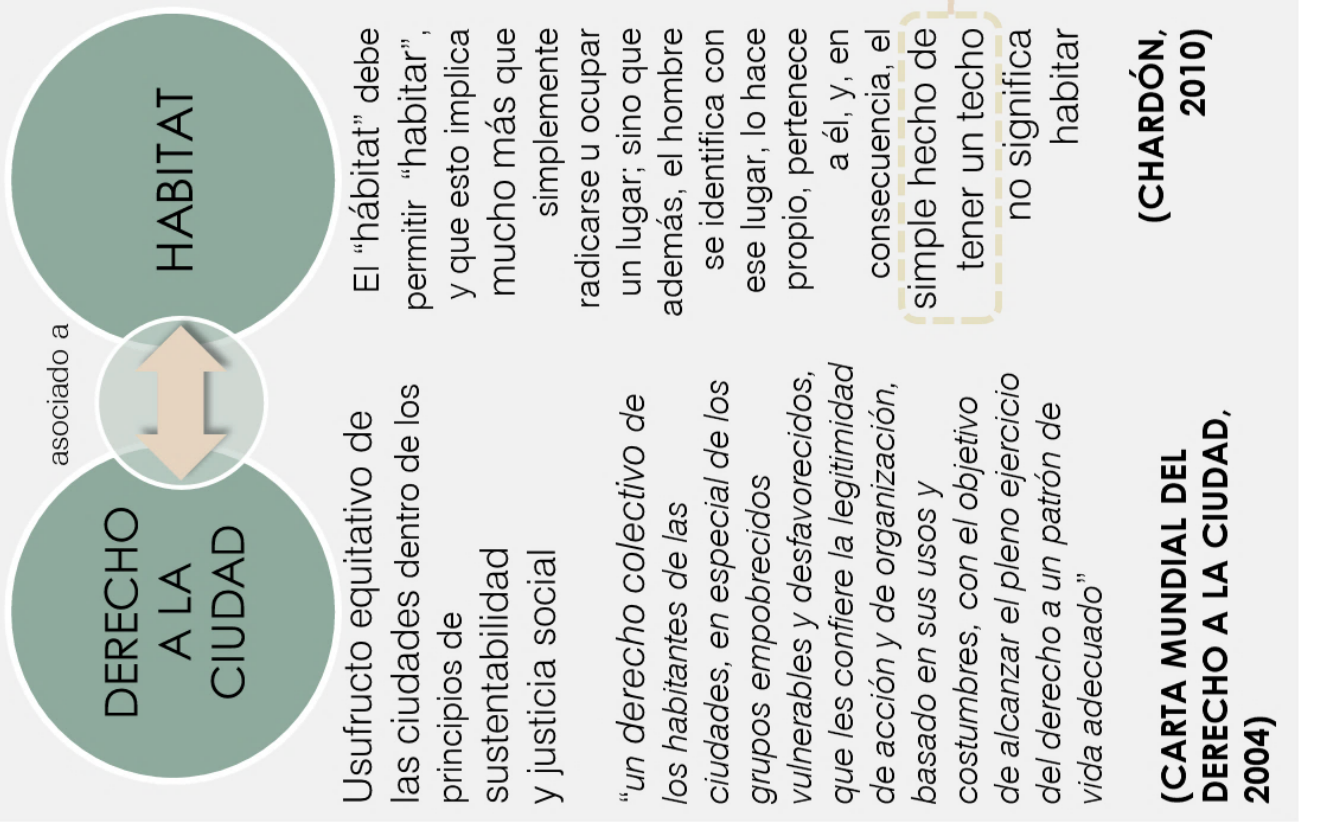

\section{$7 \forall \cap I d \exists J$ NOJ-OวIУO $\exists \perp$ OวУ $\forall W$}


PARTE 02 


\section{CAPÍTULO 3 | EL CAMINO HACIA LA CONSTRUCCIÓN DE UNA METODOLOGÍA DE ANÁLISIS DEL DERECHO A LA CIUDAD}

"La ciudad es hoy el espacio de todos los encuentros y, por lo tanto, de todas las posibilidades. Asimismo es el terreno de todas las contradicciones y de todos los peligros: en el espacio urbano de fronteras inciertas aparecen todas las discriminaciones ancladas en el paro, la pobreza, el desprecio de las diferencias culturales, mientras que, al mismo tiempo, se esbozan y se multiplican prácticas cívicas y sociales de solidaridad"

(Carta Europea de Salvaguarda de los Derechos Humanos en la Ciudad, 2000).

Este capítulo se enfocó en la definición de una serie de parámetros generales que permitieran iniciar la construcción metodológica de evaluación del derecho a la ciudad. Debido a que la "evaluación" resulta un concepto subjetivo, se buscó dar respuesta a las siguientes preguntas:

1. ¿Cuál es el objetivo de la evaluación que se va a realizar? Definiendo lo que se pretende reconocer con cada uno de los análisis. Es decir, el "para qué" de la evaluación.

2. ¿Qué es lo que se va a evaluar? Identificando y determinando los aspectos que serán evaluados. Es decir, el "qué" de la evaluación

3. ¿Qué métodos y procedimientos técnicos se van a utilizar? Seleccionando estrategias metodológicas para la evaluación. Es decir, el "cómo" de la evaluación.

A tal fin, se definieron y construyeron variables, dimensiones e indicadores, que dan cuenta de los diferentes aspectos que deben contemplarse para garantizar el derecho a la ciudad. Debido a la integralidad del concepto, resulta necesario superar la concepción de variable como mera suma de indicadores descriptivos de un fenómeno y, consecuentemente, generar un agrupamiento de estos indicadores y dimensiones en una sola expresión, ponderándolos de diferentes maneras. La resultante de esta fusión se denominará "Índice de Derecho a la Ciudad" y permitirá establecer los grados de acceso a este derecho en el área de estudio".

\subsection{Construcción de Variables, Dimensiones e Indicadores del derecho a la ciudad}

Para la evaluación del derecho a la ciudad se construyeron una serie de indicadores que refieren a distintos aspectos que debieran garantizarse en el marco del derecho a la ciudad, desde nuestro punto de vista y teniendo en cuenta el recorrido teórico desarrollado previamente; definiendo preguntas conductoras. El objetivo es generar un conocimiento más comprehensivo de la realidad que se pretende analizar.

De esta manera, se definió que los criterios que los indicadores debían cumplir eran los siguientes: en principio, que tuvieran algún tipo de expresión territorial -en términos físicos-espaciales- y que la misma fuera mensurable y pudiera representarse partir de la construcción de un mapa.

\footnotetext{
${ }^{9}$ A modo de aclaración, cabe destacar que, en esta investigación, la metodología se desarrolla para las áreas consideradas como urbanas, sin contemplar las áreas rurales. Pese a que los derechos reconocidos bajo este enfoque del derecho a la ciudad deben ser garantizados a toda la sociedad -urbana, periurbana o rural-, esta distinción se realiza ya que hay situaciones particulares para cada ámbito que deben ser estudiadas de diferente manera, requiriendo la elaboración de instrumentos específicos para cada contexto y necesidad.
} 
Este primer criterio se apoya en la concepción de que, pese a que los territorios implican muchas más cuestiones que aquellas que pueden plasmarse en un mapa desarrollado en un momento determinado como son los cambios constantes que se producen, la población que lo habita, cuestiones socioeconómicas cambiantes, entre otros-, se interpreta que "Representar el territorio es comprenderlo. Ahora bien, esta representación no es una copia sino una construcción. Se elabora un mapa, en primer lugar, para conocer, y en segundo lugar, para actuar" (A. Corboz, 2004).

También era necesario que los indicadores que se seleccionaran fueran relevantes y representativos para el conocimiento del derecho a la ciudad, abarcando la mayor cantidad de aspectos posibles, aportando desde los conocimientos específicos de un arquitecto con formación en las Ciencias del Territorio.

Otro de los criterios que los indicadores debían cumplir, fundamentalmente para una correcta elaboración de los mapas, era que los datos estuvieran disponibles, ya fuera en fuentes oficiales o, en su defecto, en otros organismos, instituciones, asociaciones.

Por último, que los indicadores fueran fácilmente interpretables y susceptibles de ser comprendidos por la gran mayoría de la población, para facilitar su posterior difusión entre los ciudadanos y otros miembros del ámbito científico-académico.

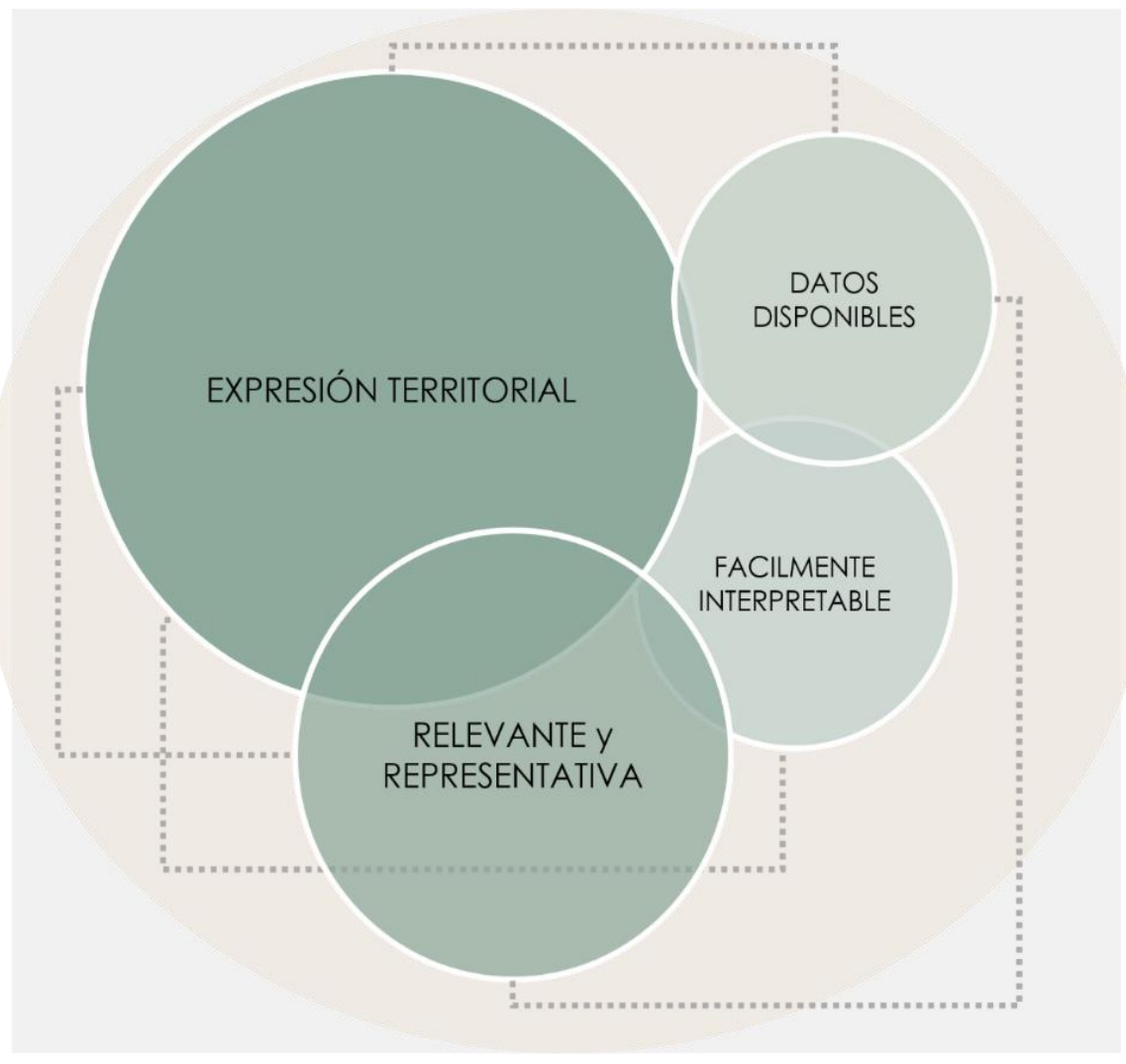

Figura 9. Criterios de construcción de las variables, dimensiones e indicadores. Elaboración propia. 2019

Una vez que se elaboraron las dimensiones y se construyeron los indicadores en función de esos criterios enunciados, se procedió a agruparlos de acuerdo a sus similitudes, definiendo variables en relación a los diferentes tipos de ciudad que se quiere alcanzar. 


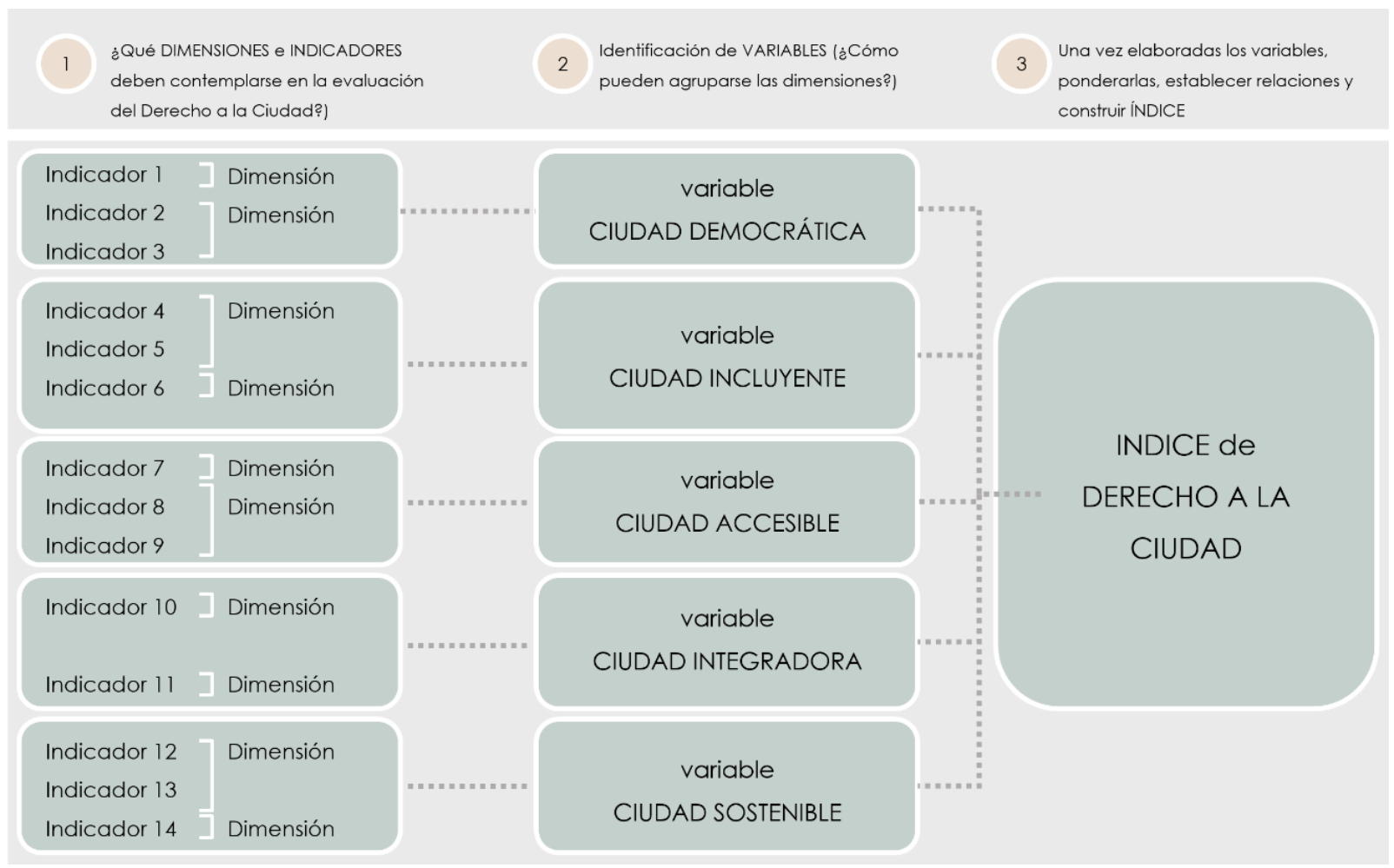

Figura 10. Construcción del índice del derecho a la ciudad. Elaboración propia. 2019

En esta línea, partiendo de los principios del derecho a la ciudad, se formuló una idea del tipo de ciudad que cada uno de estos principios representa, los derechos que deben garantizarse y los aspectos a evaluar, el objetivo de la evaluación, la escala de análisis, preguntas conductoras y fuentes de información principales. Esto permitirá, luego, definir la forma de tratamiento de cada dato.

\subsection{1 | El ejercicio pleno de la ciudadanía y la gestión democrática de la ciudad. Ciudad Democrática}

Uno de los principios del derecho a la ciudad refiere a las ciudades como ámbitos de concreción y realización de los derechos humanos y las libertades fundamentales, asegurando la dignidad y el bienestar colectivo e individual de los ciudadanos, en condiciones de igualdad, equidad y justicia.

En este caso, se tradujo en una idea de Ciudad Democrática, cuyo objetivo es el de conformar una ciudad políticamente participativa y, también, socialmente responsable; garantizando la participación de los ciudadanos en las diferentes instancias y espacios de formulación, implementación, seguimiento y evaluación de políticas públicas relacionadas a los procesos urbanos.

Los derechos que las ciudades democráticas deben garantizar están relacionados con:

- el derecho a la libertad de reunión y asociación pacíficas;

- el derecho a la manifestación pública, en sus diferentes expresiones;

- el derecho a la libertad de elección en términos de educación, cultura, lugares de residencia, entre otros;

- el derecho a la participación en la toma de decisiones acerca de asuntos públicos;

- el derecho al acceso, investigación y difusión de la información pública;

- el derecho a participar en la producción de la ciudad (en todas las formas de producción de la ciudad);

- y el derecho a la organización (en instituciones, cooperativas, colectivos, entre otros). 
Teniendo esto en cuenta, se construyeron dimensiones con sus respectivos indicadores. La primera de ellas fue la de "Participación Social", definiendo un indicador de "Legislación/Instrumentos de participación". Este indicador procura observar la existencia de mecanismos o instrumentos legislativos que fomenten y permitan la participación de la comunidad en los procesos de toma de decisiones y las acciones llevadas a cabo por el Estado, principalmente sobre cuestiones territoriales y relacionadas al hábitat. Los interrogantes que se plantearon para el análisis del indicador estuvieron relacionados a la existencia o no de instrumentos que permitan, e incluso fomenten, la participación de la sociedad en los procesos de toma de decisiones. También se indagará acerca de la existencia de mecanismos de evaluación de las acciones llevadas a cabo por el Estado en el territorio. Resulta relevante en el marco del derecho a la ciudad el garantizar que la población pueda participar de los procesos de toma de decisiones, en relación a la ciudad que se quiere alcanzar, definiendo necesidades, prioridades de acción y obligaciones para cada uno de los actores intervinientes en el proceso de planificación.

Otra de las dimensiones definidas fue "Organización de la Sociedad", con dos indicadores. El primero de ellos se denomina "Organizaciones Sociales", a partir del cual se procura verificar la presencia en el territorio de estas organizaciones, en términos de un espacio físico que sea una referencia y al cual la sociedad pueda dirigirse en caso de manifestar alguna necesidad social. Así, las preguntas conductoras del análisis de este indicador refieren, en principio, a la existencia y presencia de organizaciones sociales en el territorio -particularmente organizaciones que atiendan problemáticas con expresión territorial-, y a la consideración de si, en el marco de garantizar esta presencia, estas organizaciones poseen un espacio físico identificable que permita el desarrollo de actividades al interior del mismo. La importancia de este indicador radica en el rol que las organizaciones sociales han tenido, particularmente en los últimos tiempos, en la lucha por las mejoras en la calidad de vida de la población, en la exigencia de mayor participación en las políticas públicas y en los procesos de ocupación del territorio. Por tal motivo, resulta fundamental que posean un anclaje en el territorio y un espacio físico reconocible y accesible para la población.

En esta línea, y entendiendo a la producción social del hábitat como una forma de construcción de las ciudades, particularmente de aquella población de bajos recursos que no pueden acceder a una vivienda a través de los mecanismos formales, otra de los indicadores que se definió en el marco de la dimensión "Organización de la Sociedad" es el de "Producción Social del Hábitat". El objetivo, en este caso, es observar si existen procesos de producción social del hábitat y si el Estado participa en ellos o son exclusivamente de autoconstrucción sin participación estatal. Resulta fundamental evaluar este aspecto y el acompañamiento que realiza el Estado de estos procesos que permiten el acceso a una vivienda por parte de sectores desfavorecidos. Las preguntas conductoras que se plantean como guía para el análisis de este indicador se relacionan a la existencia/inexistencia de procesos de producción social del hábitat, su localización y la posibilidad de observar la presencia del Estado, verificando, además, de qué manera se produce este apoyo (¿Se define algún tipo de normativa especial? ¿Se producen impulsos fiscales, a través de, por ejemplo, la reducción de impuestos? ¿Se conforman equipos interdisciplinarios que permitan el trabajo con las comunidades?).

Por último, se construyó la dimensión de "Información Pública", con un indicador específico de "Información Territorial" enfocado en la comunicación de aspectos relacionados con el territorio de análisis. Con el análisis de este indicador se procura verificar si la población tiene libertad de acceso a la información relacionadas a aspectos urbano territoriales ya sea a través de páginas web, portales de datos abiertos; que permitan la consulta de presupuestos destinados a obras, expedientes en curso, normativas vigentes $u$ otros datos de interés. Las preguntas guía serán: ¿el Municipio cuenta con página web? ¿qué tipo de información brinda?, ¿se informa acerca de las intervenciones territoriales?, ¿tiene un portal de datos abiertos de fácil acceso? La importancia de poder contar con esta información radica en que, muchas veces, los derechos a los que la población puede acceder no tienen el suficiente arraigo cultural, $y$, por ende, la sociedad no los reclama. Ante esto, el acceso a la información genera mecanismos de empoderamiento, fomenta el reclamo ante la necesidad y aumenta el control de los actores encargados de llevar a cabo las intervenciones territoriales (el Estado, las empresas intervinientes, entre otros). 


\subsection{2 | La promoción del acceso a los servicios básicos. Ciudad Accesible}

En el marco de garantizar el derecho a la ciudad, las ciudades deben generar las condiciones para el desarrollo de una vida digna y de calidad para todas las personas. Por este motivo, se construyó la variable Ciudad Accesible, que tiene como objetivo generar una ciudad que permita democratizar el acceso y la asequibilidad a los servicios básicos (agua, saneamiento, energía, etc.) y al transporte público; fomentando además el acceso a una vivienda digna en un hábitat adecuado.

Los derechos que se deben garantizar están relacionados con:

- el derecho al transporte público y la movilidad urbana;

- el derecho a contar con servicios públicos básicos (agua, saneamiento, energía) y de recolección de residuos:

- el derecho a la alimentación.

En el marco de esta variable, se construyeron tres dimensiones: "Movilidad Urbana", "Infraestructuras de Servicios" y "Alimentación". En relación a la movilidad urbana se definió un primer indicador de "Transporte Público", que procura evaluar si el área de estudio posee transporte público, a partir de estudiar los recorridos de micro que circulen por el sector y las paradas (refugios). En esta línea, las preguntas conductoras del análisis se relacionan a: ¿qué acceso tiene la población del área de estudio al servicio de transporte público?, ¿cómo es el acceso al sector?, ¿qué conexiones se establecen con las áreas centrales?.

La importancia de evaluar este indicador radica en que las ciudades deben transformarse en espacios sostenibles que fomenten el uso del transporte público como alternativa al vehículo privado, debido a que este genera un menor impacto ambiental en las ciudades. Por ende, resulta fundamental conocer la cobertura de este servicio, la cantidad de líneas de transporte que recorren el sector y la existencia de paradas que funcionen como refugio para la población al momento de la espera del transporte; garantizando la conexión de la población con distintas áreas que permitan el desarrollo de actividades administrativas, de ocio, de acceso a la educación, entre otras.

En línea con este indicador, se construyó otro denominado "Vías de Circulación" que apunta a evaluar la existencia de vías de circulación pavimentadas, que permitan una circulación fluida del transporte, tanto público como privado. Las vías de acceso pavimentadas resultan importantes, no sólo para los movimientos de la población y la posibilidad de acceder a espacios de ocio, esparcimiento y demás actividades para el desarrollo de la vida humana; sino porque, además, posibilitan el acceso al transporte público, a los servicios de emergencia y a vías de evacuación adecuadas en caso de eventos que así lo requieran.

La segunda de las dimensiones definidas fue la de "Infraestructura de Servicios", en la cual se construyeron indicadores de análisis de cada uno de los servicios básicos: "Cloacas", "Agua Corriente", "Electricidad", "Alumbrado Público", "Gas" y también "Recolección de Residuos". Cada uno de estos indicadores resulta importante en pos de evaluar el derecho a la ciudad, debido a que la población debe poder acceder a los servicios básicos, que garanticen una vida sana y una vivienda digna.

La evaluación deberá contemplar dos aspectos, en principio el acceso en términos de proximidad (cobertura del servicio) y, en segunda instancia, el acceso en términos de asequibilidad económica al servicio. Teniendo en cuenta el mundo globalizado en el que vivimos, y la importancia de la conectividad y el acceso a internet - para el desarrollo de múltiples actividades (administrativas, laborales, entre otras), se construyó un indicador de "Conectividad Digital" que procura evaluar el acceso de la población al servicio de internet, contemplando los siguientes interrogantes: ¿cuál es el radio de cobertura de la conectividad digital?, ¿la población cuenta con acceso a redes WiFi públicas y gratuitas?. 
Además, se definió una tercera dimensión relacionada al "Desarrollo Social" en la que se construyeron diversos indicadores. El primero de ellos, contempla el derecho a la alimentación, a partir del análisis en el territorio de la existencia de "Centros de Apoyo para el acceso a los Alimentos" a los cuales la población pueda acudir en caso de no tener acceso a las comidas básicas y fundamentales (algunos ejemplos de estos centros son: la Copa de Leche, Centros de Atención de organizaciones religiosas, establecimientos educativos que provean el servicio de merienda). La alimentación adecuada está directamente relacionada con la salud y, por ende, es fundamental evaluar-desde los aspectos territoriales y el derecho a la ciudad- el acceso que tiene la población a establecimientos que permitan satisfacer esta necesidad básica.

A continuación, se construyeron una serie de indicadores basados en el estudio de diferentes programas y servicios administrados por el Ministerio de Desarrollo Social ${ }^{10}$, destinados a que todos los habitantes puedan mejorar su calidad de vida.

En esta línea, el primero de los indicadores definidos fue el de "Centros de Referencia (CDR)", a través del cual se procura evaluar la existencia de estos espacios que funcionan como sedes del Ministerio de Desarrollo Social y en los cuales se pueden desarrollar trámites como el del Monotributo Social y acceder a otros programas y servicios del Ministerio; dando respuesta a interrogantes como: ¿existen Centros de Referencia en el área de estudio?; ¿son fácilmente identificables para que la población pueda acceder a ellos?; ¿en qué sector se localizan?, entre otros.

Otro de los indicadores hace referencia a los "Centros Integradores Comunitarios (CIC)", espacios que permiten la participación de la población en diversas actividades (recreativas, educativas, formativas) y, en ocasiones, el acceso a atención médica. Los interrogantes nuevamente estarán relacionados a la existencia de estos centros en el área de estudio, a su capacidad de ser identificables para la población y también al tipo de actividades que se pueden desarrollar en torno a los mismos.

El Ministerio de Desarrollo Social también tiene programas de Microcréditos para que la población que posee emprendimientos de Economía Social pueda acceder a la compra de insumos, materiales y herramientas para el desarrollo de sus actividades. Por este motivo se construyó otro indicador denominado "Instituciones de Microcrédito (IM)", en el que se evalúa la existencia de estos establecimientos en el territorio.

Otro indicador es el de "Ferias Permanentes (FP)", entendiendo que son espacios en los que la población puede acceder a diferentes insumos y productos elaborados por emprendedores locales; evaluándolo a partir de reconocer su existencia o no en el territorio, estudiando en qué zonas se localizan (por ende, cuánta población tiene acceso a ellas) y también el tipo de productos que se ofrecen y la demanda que satisfacen.

Por último, se definió un indicador en el que se analiza la existencia de espacios "ProHuerta (PH)" en el área de estudio; centros en los que se puede acceder a asesoramiento técnico, insumos y capacitaciones para crear huertas familiares o comunitarias.

\subsection{3 | Igualdad entre todos los habitantes. Ciudad Integradora}

El derecho a la ciudad tiene como otro de sus principios garantizar la igualdad entre todos los habitantes, sin ningún tipo de discriminación, permitiendo y alentando la vida en comunidad. En este caso, este principio se traduce en una variable denominada Ciudad Integradora, cuyo objetivo es garantizar igualdad de condiciones entre la sociedad, y fortalecer los mecanismos que permitan la construcción de una ciudadanía responsable y activa, que pueda participar y disfrutar de la ciudad.

\footnotetext{
${ }^{10}$ Cabe destacar que este tipo de programas se desarrollan en la actualidad, por ende, en caso de que alguno de ellos se diera de baja, deberá contemplarse la posibilidad de plantear otros indicadores para el análisis de esta variable
} 
De esta forma, los derechos que se deben garantizar están relacionados con:

- el derecho a una vivienda, que presente condiciones dignas para el habitar;

- el derecho a la libertad de residencia en la ciudad; permitiendo la libre elección de un espacio para habitar, siempre contemplando que estos lugares sean aptos y tengan condiciones adecuadas para tal fin;

- el derecho al arraigo, es decir, a sentirse parte de un espacio y un lugar;

- el derecho a trabajar, pudiendo acceder a los mecanismos para garantizar la posibilidad de desarrollarse en este sentido.

Así, se construyeron dos variables que resumen las cuestiones principales que deben contemplarse en el marco de este principio y que tienen una expresión territorial que permite su evaluación.

La primera de ellas, denominada "Acceso al Suelo", refiere a la capacidad de acceder al recurso suelo por parte de los ciudadanos, así como a la acción del Estado ante la población incapaz de satisfacer esta necesidad.

Se construyeron a tal fin, tres indicadores. El primero de ellos, "Banco de Tierras", tiene como objetivo verificar si el Estado estos repositorios de terrenos que puedan responder a la demanda de vivienda y al déficit urbano habitacional, entendiendo por tal a "la escasez, calidad insuficiente o inaccesibilidad a condiciones materiales, servicios y espacios aptos para satisfacer las necesidades y promover una mejor calidad de vida de la población en el marco de un hábitat ambientalmente sostenible" (Art.4. Ley de Acceso Justo al Hábitat, 2012). Así, pese a que existen diversas formas de actuar ante el déficit urbano habitacional, la creación y existencia de bancos de tierra permite el impulso de planes de vivienda u otros espacios necesarios para el desarrollo de la vida en comunidad (espacios recreativos, complejos deportivos, complejos educativos, entre otros), tendiendo a la integración y a la cohesión social en una ciudad.

El segundo de los indicadores se denomina "Planes de Vivienda" y a partir de él se observa la existencia de viviendas desarrollados por el Estado en el sector de análisis, así como las características principales de estas intervenciones; teniendo como referencia los siguientes interrogantes: ¿la demanda de vivienda se satisface en el sector a partir de la construcción y el desarrollo de planes de vivienda?; ¿qué tipo de planes de vivienda se desarrollan?; ¿sólo se construyen viviendas o hay otros desarrollos (espacio público, áreas de recreación, áreas destinadas a educación, salud, etc.)?; ¿en qué área se localizan los planes de vivienda?.

Se trata de un indicador de gran relevancia en el marco del derecho a la ciudad y, específicamente, en relación al principio de garantizar una ciudad integradora que facilite la igualdad entre todos sus habitantes; debido a que el acceso a la vivienda es uno de los principales factores de segregación en las ciudades. Cabe destacar que no es simplemente el acceso a una vivienda (a un techo), sino que deben contemplarse otros factores que hacen al hábitat. Pese a esto, las actuaciones en torno a garantizar la vivienda resultan estratégicas para evitar la exclusión social y garantizar la integración de los habitantes, como puede analizarse en la Ley de Acceso Justo al Hábitat que en su artículo $3^{\circ}$ define que "El derecho a una vivienda y a un hábitat digno comporta la satisfacción de las necesidades urbanas y habitacionales de los ciudadanos de la Provincia, especialmente de quienes no logren resolverlas por medio de recursos propios, de forma de favorecer el ejercicio pleno de los derechos fundamentales" (Ley de Acceso Justo al Hábitat, 2012).

El tercero de los indicadores construidos hace referencia al "Valor de/ Suelo", a partir del cual se procura medir el valor del suelo para evaluar la posibilidad de acceder a un terreno y una vivienda digna en el área de estudio, tomando como referencia los siguientes interrogantes: ¿Cuál es el valor del suelo promedio en el área de estudio? ¿Se trata de terrenos accesibles para la población? ¿Cómo se relaciona con el ingreso promedio de la población?. De esta forma, retomando el concepto de las ciudades injustas planteado en el segundo capítulo, se entiende que resulta relevante indagar en la capacidad de los 
habitantes de acceder a un terreno o vivienda propia, favoreciendo la integración de los ciudadanos y su inserción en contextos urbanos.

A continuación, se definió una variable denominada "Vivienda" y una serie de indicadores que hacen a las características de las viviendas y de la ocupación de las mismas. El primero de ellos refiere al "Tipo de Vivienda" y tiene como objetivo dar cuenta de las condiciones en las que se encuentran, asignando un valor a cada tipo de vivienda (de acuerdo a los parámetros del Censo Nacional de Población, Hogares y Viviendas ${ }^{11}$ ), definiendo situaciones óptimas y deficitarias.

Un segundo indicador apunta a la medición de la "Cantidad de Habitantes" que ocupan una vivienda, con el objeto de reconocer si se encuentran en condiciones de hacinamiento crítico, entendido como aquellos hogares en los que habitan más de tres personas por cuarto (según la definición del Censo Nacional de Población, Hogares y Viviendas, 2010).

Se define un tercer indicador que apunta al reconocimiento de "Hogares con Necesidades Básicas Insatisfechas", nuevamente utilizando como referencia la definición del Censo Nacional de Población, Hogares y Vivienda (2010) que entiende a los mismos como aquellos hogares en los que se observa al menos una de las siguientes condiciones de privación:

- $\mathrm{NBI}$ 1. Vivienda: son los hogares que viven en habitaciones de inquilinato, hotel o pensión, viviendas no destinadas a fines habitacionales, viviendas precarias y otro tipo de vivienda. Se excluye a las viviendas tipo casa, departamento y rancho.

- $\quad \mathrm{NBI}$ 2. Condiciones sanitarias: incluye a los hogares que no poseen inodoro.

- NBI 3. Hacinamiento: es la relación entre la cantidad total de miembros del hogar y la cantidad de habitaciones de uso exclusivo del hogar. Operacionalmente, se considera que existe hacinamiento crítico cuando en el hogar hay más de tres personas por cuarto.

- NBI 4. Asistencia escolar: hogares que tienen al menos un niño en edad escolar (6 a 12 años) que no asiste a la escuela.

- NBI 5. Capacidad de subsistencia: incluye a los hogares que tienen cuatro o más personas por miembro ocupado y tienen un jefe que no ha completado el tercer grado de escolaridad primaria.

Teniendo en cuenta que las viviendas deben tener condiciones dignas para poder habitar en ellas, resultan indicadores fundamentales que reconocen, entre otras cuestiones, las características principales de las mismas (en relación a la materialidad de sus paredes, pisos y techo, entre otros aspectos). Así, se evaluarán las viviendas, desde aquellas más aptas para el habitar, hasta las menos aptas.

Finalmente, un último indicador procura evaluar el "Régimen de Tenencia" de las viviendas, evaluando si se trata de propietarios, inquilinos, o hay condiciones de ocupación informal. Resulta importante reconocer

\footnotetext{
${ }^{11}$ De acuerdo al Glosario del Censo Nacional de Población, Hogares y Viviendas (2010) se reconocen los siguientes tipos de viviendas particulares:

- Casa: vivienda con salida directa al exterior construida originalmente para que habiten personas.

- Rancho: vivienda con salida directa al exterior, generalmente con paredes de adobe, piso de tierra y techo de chapa o paja.

- $\quad$ Casilla: vivienda con salida directa al exterior, habitualmente construida con materiales de baja calidad o de desecho.

- Departamento: vivienda que forma parte de un edificio o estructura con una entrada común que contiene por lo menos dos viviendas a la que se accede a través de pasillos, escaleras, zaguanes o ascensores de uso común.

- Pieza en inquilinato: ambiente ubicado en un inquilinato o conventillo, es una edificación para contener varias piezas que tienen salida a uno o más espacios de uso común con la finalidad de alojar en forma permanente personas en calidad de inquilinos

- $\quad$ Pieza en hotel familiar o pensión: ambiente ubicado en un hotel familiar o pensión; es una edificación para contener varias piezas que tienen salida a uno o más espacios de uso común con la finalidad de alojar en forma permanente personas en calidad de huéspedes o pensionistas.

- $\quad$ Local no construido para habitación: vivienda que no ha sido construida o adaptada para que habiten personas

- Vivienda móvil: estructura que es utilizada como vivienda, construida para ser transportada o que constituye una unidad móvil

- Personas viviendo en la calle: espacio en la vía pública (calle, estación del ferrocarril, estación del subterráneo, portal de edificio, plaza, etc.) utilizado por las personas como lugar de habitación y/o pernocte
} 
esta cuestión ya que la tenencia de la propiedad garantiza el derecho al arraigo en un lugar (no sólo a la vivienda), un derecho fundamental a garantizar en el marco del derecho a la ciudad.

Finalmente se construyó una dimensión orientada a evaluar el acceso de la población a la "Formación Profesional", a partir de un indicador de "Centros de Formación Profesional y Oficios" que observa la existencia de estos centros de formación gratuita en el área de estudio. Es importante estudiar el acceso de la población a estos centros por diversas cuestiones pero, fundamentalmente, porque capacitar a la población permite fortalecer la construcción de ciudadanía, factor imprescindible para que los ciudadanos puedan exigir y hacer valer sus derechos.

\subsection{4 | Respeto por el medio ambiente. Ciudad Sostenible}

En el marco del derecho a la ciudad, otro de los principios que debe garantizarse es el del respeto por el medio ambiente, entendiendo que las ciudades deben fomentar procesos ordenados de ocupación del territorio, procurando proteger las áreas ambientalmente vulnerables y recursos fundamentales para la vida. Este principio se traduce en la variable Ciudad Sostenible, cuyo objetivo es generar una ciudad habitable, saludable, segura y disfrutable, que permita el uso de los recursos naturales sin agotarlos en el tiempo presente, al mismo tiempo que preserve la naturaleza para las generaciones futuras

Así, los derechos que deben garantizarse están relacionados con:

- el derecho a vivir en un medio ambiente sano;

- el derecho a la protección, preservación y mejoramiento del medio ambiente;

- el derecho al acceso y uso del territorio dentro de condiciones sustentables;

- y el derecho a la integridad física frente a los riesgos y desastres naturales.

En este sentido, se definieron dos dimensiones fundamentales para el análisis de los aspectos que hacen a una ciudad sostenible. La primera de ellas, es la "Idea de Ciudad", estudiada a partir de dos indicadores: "Legislación sobre Usos del Suelo" y "Legislación sobre Energías Sostenibles".

Así, a partir del estudio de la legislación sobre usos del suelo, se busca interpretar la existencia de normativas que definan el destino de la ciudad, la "idea de ciudad" que se pretende alcanzar, entendiendo que la importancia de analizar este aspecto radica en la necesidad de definir un modelo hacia el cual la ciudad debe tender, que considere aspectos fundamentales que permitan el desarrollo de una vida de calidad adecuada a todos los habitantes. De esta forma, se plantean como interrogantes fundamentales: ¿Qué usos del suelo se definen en la legislación? ¿Se respetan estos usos o se observa incompatibilidad de usos? ¿Hay limitaciones para preservar el ambiente y los recursos naturales del área?.

El segundo de los indicadores procura observar la existencia de legislación en materia del uso de energías sostenibles que sean aplicables al área de estudio. Coincidentemente con la concepción de una ciudad sostenible, que permita el desarrollo no sólo de las generaciones actuales sino también de las generaciones futuras y que procure -a tal fin- el cuidado de los recursos naturales, resulta relevante estudiar si se ha desarrollado legislación en relación al uso de energías renovables, y si este tipo de energías se aplica en el área de estudio.

Por último, se definió una dimensión tendiente a evaluar los "Riesgos Ambientales" que tengan una fuerte expresión territorial. Así, se construyeron tres indicadores. El primero de ellos, refiere a las industrias, particularmente al análisis de las "Industrias Contaminantes". El indicador apunta a observar la existencia de industrias de este tipo en el sector, sus características principales (en términos del grado de contaminación que generan) y, fundamentalmente, la localización de las mismas, a fin de reconocer si se localizan en áreas destinadas a estos fines, protegiendo a la población de los efectos que pudieran generar. 
El segundo de los indicadores busca verificar la existencia de sectores que se encuentren en condición de "Riesgo Hídrico" en el área de estudio, determinando superficies afectadas y a la población que se asienta en esas zonas. Resulta fundamental la indagación en relación a este indicador, debido a que el fenómeno de las inundaciones ha sido una constante en los últimos tiempos, generando tanto pérdidas materiales como humanas. De esta forma y el conocimiento de estas cuestiones permite la intervención en pos de mitigar esta problemática.

Otro de los indicadores es el de "Cavas" que observa la existencia de explotaciones orientadas a la actividad extractiva en el área de estudio, a partir de los siguientes interrogantes: ¿Se observa la presencia de cavas en el área de estudio? ¿Qué superficie del área ocupan? ¿Hay población asentada en las cercanías de las mismas?. Resulta un aspecto fundamental a considerar, ya que esta actividad genera riesgos ambientales a la población debido a la extracción de suelo productivo, a la contaminación de las napas y a la fragilidad ambiental y territorial que genera en su entorno.

\subsection{5 | El usufructo equitativo de las ciudades. Ciudad incluyente}

Como ya fuera explicitado en el marco conceptual, uno de los principios del derecho a la ciudad es el del usufructo equitativo de las ciudades, entendiendo que éstas deben ofrecer las condiciones para que todos los habitantes puedan usar y gozar de los recursos; generando espacios urbanos que promuevan y estimulen el encuentro, el intercambio y la expresión de los ciudadanos.

Este principio se tradujo en una idea de ciudad para todos, una Ciudad Incluyente, que tienda a fortalecer la convivencia social, la generación y mejoramiento de los espacios públicos; y, de igual modo, consolidar la función cultural, lúdica y recreativa del espacio público; así como el acceso a la educación y la salud como dúo inseparable. Así, los derechos que se deben garantizar -y de los cuales pudo reconocerse una expresión territorial- fueron los siguientes:

- el derecho a la igualdad ante la ley, sin discriminaciones y aceptando las diferencias e individualidades de cada ciudadano;

- el derecho a la educación (en sus diferentes instancias -inicial, primaria, secundaria-);

- el derecho a la convivencia pacífica, solidaria y multicultural;

- el derecho a disponer de espacios públicos, lúdicos y deportivos de calidad y accesibles para la convivencia y el encuentro;

- el derecho a participar en la vida cultural y a la libre expresión de las manifestaciones culturales;

- y el derecho a espacios seguros donde desarrollar actividades individuales y colectivas.

En base a esta variable y los derechos que deben contemplarse, se definieron cuatro dimensiones: recreación, educación, salud y culto. La definición de estas dimensiones y cada uno de los indicadores que las componen, se realiza en el siguiente capítulo de aplicación de la metodología; y por tal motivo no se desarrollan en este apartado.

\section{2 | Consideraciones generales}

Con este acervo de aspectos y cuestiones generales a considerar para la evaluación del derecho a la ciudad en el territorio, se procedió a sintetizar las cuestiones más importantes en la siguiente matriz síntesis. 


\section{EJERCICIO PLENO DE LA CIUDADANÍA y GESTIÓN DEMOCRÁTICA DE LA CIUDAD}

Las ciudades deben ser un ámbito de realización de todos los derechos humanos y libertades fundamentales, asegurando la dignidad y el bienestar colectivo de todas las personas, en condiciones de igualdad, equidady justicia

\begin{tabular}{|c|c|c|c|c|c|c|}
\hline VARIABLE & DIMENSIÓN & INDICADOR & DESCRIPCIÓN del INDICADOR & OBJETIVO de la MEDICIÓN & PREGUNTAS CONDUCTORAS & $\begin{array}{l}\text { ESCALA DE } \\
\text { ANALISIS }\end{array}$ \\
\hline $\begin{array}{l}\text { CIUDAD } \\
\text { DEMOCRATICA }\end{array}$ & $\begin{array}{l}\text { PARTICIPACIÓN } \\
\text { SOCIAL }\end{array}$ & $\begin{array}{l}\text { Legislación/ } \\
\text { Instrumentos de } \\
\text { participación }\end{array}$ & $\begin{array}{l}\text { El indicador procura observar si existen } \\
\text { mecanismos/instrumentos legislativos que } \\
\text { fomenten y permitan la participación de la } \\
\text { comunidad en los procesos de toma de decisiones } \\
\text { y las acciones llevadas a cabo por el Estado sobre } \\
\text { cuestiones territoriales }\end{array}$ & $\begin{array}{l}\text { Resulta relevante en el marco del derecho a la ciudad el } \\
\text { garantizar que la población pueda participar de los } \\
\text { procesos de toma de decisiones, en relación a la } \\
\text { ciudad que se quiere alcanzar, definiendo necesidades, } \\
\text { prioridades de acción y obligaciones para cada uno de } \\
\text { los actores intervinientes en el proceso de planificación }\end{array}$ & $\begin{array}{l}\text { LExisten instrumentos que } \\
\text { permitan/fomenten la participación de la } \\
\text { sociedad en los procesos de toma de } \\
\text { decisiones? ¿Existen mecanismos de } \\
\text { evaluación de las acciones llevadas a cabo } \\
\text { por el Estado en el territorio? }\end{array}$ & MACRO \\
\hline \multirow{3}{*}{$\begin{array}{l}\text { El objetivo es } \\
\text { conformar una } \\
\text { ciudad } \\
\text { políticamente } \\
\text { participativay, } \\
\text { también, } \\
\text { socialmente } \\
\text { responsable; } \\
\text { garantizando a } \\
\text { participación de } \\
\text { los ciudadanos } \\
\text { en las diferentes } \\
\text { instanciasy } \\
\text { espacios de } \\
\text { formulación, } \\
\text { implementación, } \\
\text { seguimiento y } \\
\text { evaluación de } \\
\text { políticas } \\
\text { públicas } \\
\text { relacionadas a } \\
\text { los procesos } \\
\text { urbanos }\end{array}$} & \multirow[t]{2}{*}{$\begin{array}{l}\text { ORGANIZACIÓN DE } \\
\text { LA SOCIEDAD }\end{array}$} & Organizaciones Sociales & $\begin{array}{l}\text { A partir de este indicador se procura verificar si las } \\
\text { organizaciones sociales tienen presencia en el } \\
\text { territorio, en términos de un espacio físico que sea } \\
\text { una referencia en el territorio y al cual la sociedad } \\
\text { pueda dirigirse en caso de manifestar alguna } \\
\text { preocupación o necesidad social }\end{array}$ & $\begin{array}{l}\text { La importancia de este indicador radica en el rol que las } \\
\text { organizaciones sociales han tenido, particularmente en } \\
\text { los últimos tiempos, en la lucha por las mejoras en la } \\
\text { calidad de vida de la población, en la exigencia de } \\
\text { mayor participación en las políticas públicas y en los } \\
\text { procesos de ocupación del teritorio. Por tal motivo, } \\
\text { resulta fundamental que posean un anclaje en el } \\
\text { territorio y un espacio físico reconocible y accesible } \\
\text { para la población }\end{array}$ & $\begin{array}{l}\text { ¿Se observa la presencia de } \\
\text { organizaciones sociales en el territorio? } \\
\text { (Particularmente organizaciones que } \\
\text { atiendan problemáticas con expresión } \\
\text { territorial) ¿Estas organizaciones poseen } \\
\text { un espacio físico identificable que permita } \\
\text { el desarrollo de actividades al interior del } \\
\text { mismo? }\end{array}$ & MICRO \\
\hline & & $\begin{array}{c}\text { Producción Social del } \\
\text { Hábitat }\end{array}$ & $\begin{array}{l}\text { Observar si existen procesos de producción social } \\
\text { del hábitat, y si el Estado participa en estos } \\
\text { procesos o son exclusivamente de } \\
\text { autoconstrucción sin participación estatal. }\end{array}$ & $\begin{array}{l}\text { Resulta fundamental evaluar este aspecto y, } \\
\text { particularmente, el acompañamiento que realiza el } \\
\text { Estado de estos procesos que permiten el acceso a } \\
\text { una vivienda por parte de sectores desfavorecidos }\end{array}$ & $\begin{array}{l}\text { ¿Se observan procesos de producción } \\
\text { social del hábitat? ¿Dónde se encuentran } \\
\text { localizados? ¿El Estado acompaña/ apoya } \\
\text { estos procesos? ¿De qué manera? ¿Se } \\
\text { define algún tipo de normativa especial? } \\
\text { ¿Se producen impulsos fiscales, a través } \\
\text { de, por ejemplo, la reducción de } \\
\text { impuestos? ¿Se conforman equipos } \\
\text { interdisciplinarios que permitan el trabajo } \\
\text { con las comunidades? }\end{array}$ & MICRO \\
\hline & $\begin{array}{l}\text { INFORMACIÓN } \\
\text { PÚBLICA }\end{array}$ & Información Territorial & $\begin{array}{l}\text { Con el análisis de este indicador se procura } \\
\text { verificar si la población tiene libertad de acceso a la } \\
\text { información, en términos de intervenciones } \\
\text { territoriales (a través de páginas web, portales de } \\
\text { datos abiertos, etc., que permitan la consulta de } \\
\text { presupuestos destinados a obras, expedientes en } \\
\text { curso, normativas vigentes, etc.). }\end{array}$ & $\begin{array}{l}\text { La importancia de poder contar con esta información } \\
\text { radica en que, muchas veces, los derechos a los que la } \\
\text { población puede acceder no tienen el suficiente arraigo } \\
\text { cultural, y, por ende, la sociedad no los reclama. Ante } \\
\text { esto, el acceso a la información genera mecanismos de } \\
\text { empoderamiento, fomenta el reclamo ante la necesidad } \\
\text { y el control de los actores encargados de llevar a cabo } \\
\text { las intervenciones territoriales }\end{array}$ & $\begin{array}{l}\text { ¿El Municipio cuenta con página web? } \\
\text { ¿Qué tipo de información brinda? ¿Se } \\
\text { informa acerca de las intervenciones } \\
\text { territoriales? ¿Tiene un portal de datos } \\
\text { abiertos de fácil acceso? }\end{array}$ & MACRO \\
\hline
\end{tabular}




\section{PROMOCIÓN DEL ACCESO A LOS SERVICIOS BÁSICOS}

Las ciudades deben generar las condiciones para el desarrollo de una vida digna y de calidad para todas las personas

\begin{tabular}{|c|c|c|c|c|c|c|}
\hline VARIABLE & DIMENSIÓN & INDICADOR & DESCRIPCIÓN del INDICADOR & OBJETIVO de la MEDICIÓN & PREGUNTAS CONDUCTORAS & $\begin{array}{l}\text { ESCALA DE } \\
\text { ANALISIS }\end{array}$ \\
\hline \multirow{15}{*}{$\begin{array}{l}\text { CIUDAD } \\
\text { ACCESIBLE } \\
\text { El objetivo es } \\
\text { generar una } \\
\text { ciudad } \\
\text { accesible que } \\
\text { permita } \\
\text { democratizar } \\
\text { el acceso y la } \\
\text { asequibilidad } \\
\text { a los } \\
\text { servicios } \\
\text { básicos } \\
\text { (agua, } \\
\text { saneamiento, } \\
\text { energía, etc.) } \\
\text { y al transporte } \\
\text { público; } \\
\text { fomentando el } \\
\text { acceso a una } \\
\text { vivienda } \\
\text { digna en un } \\
\text { hábitat } \\
\text { adecuado }\end{array}$} & \multirow[t]{2}{*}{$\begin{array}{l}\text { MOVILIDAD } \\
\text { URBANA }\end{array}$} & $\begin{array}{l}\text { Transporte } \\
\text { público }\end{array}$ & $\begin{array}{l}\text { El indicador procura observar la existencia de paradas de transporte } \\
\text { público }\end{array}$ & $\begin{array}{l}\text { La importancia de evaluar este indicador radica en el fomento } \\
\text { del uso del transporte público como alternativa al transporte } \\
\text { privado para garantizar ciudadeses sostenibles, debido a que } \\
\text { este uso genera un menor impacto ambiental en las ciudades. } \\
\text { Por eso resulta fundamental conocer la cobertura de este } \\
\text { servicio de transporte público }\end{array}$ & $\begin{array}{l}\text { ¿Qué acceso tiene la población del área de estudio } \\
\text { al servicio de transporte público? ¿Cómo es el } \\
\text { acceso al sector? ¿Qué conexiones se establecen } \\
\text { con las áreas centrales? }\end{array}$ & MICRO \\
\hline & & $\begin{array}{l}\text { Vías de } \\
\text { Circulación }\end{array}$ & $\begin{array}{l}\text { A partir del análisis del indicador se mide la existencia de vías de } \\
\text { circulación pavimentadas en el área de estudio }\end{array}$ & $\begin{array}{l}\text { Las vías de acceso pavimentadas resultan importantes no } \\
\text { sólo para los movimientos de la población sino porque } \\
\text { además posibilitian el acceso al transporte público, a los } \\
\text { servicios de emergencia a a vías de evacuación adecuadas en } \\
\text { caso de eventos que requieran el escape de la población }\end{array}$ & $\begin{array}{l}\text { ¿Existen vías de circulación pavimentadas en el } \\
\text { sector? ¿Es posible el acceso/egreso del sector a } \\
\text { partir de vías pavimentadas? (facilidad de } \\
\text { accesibilidad) }\end{array}$ & MICRO \\
\hline & \multirow[t]{7}{*}{$\begin{array}{l}\text { INFRAESTRUCT } \\
\text { URAS DE } \\
\text { SERVICIOS }\end{array}$} & Cloacas & El indicador evalúa la existencia de cloacas en el sector de análisis & \multirow{6}{*}{ 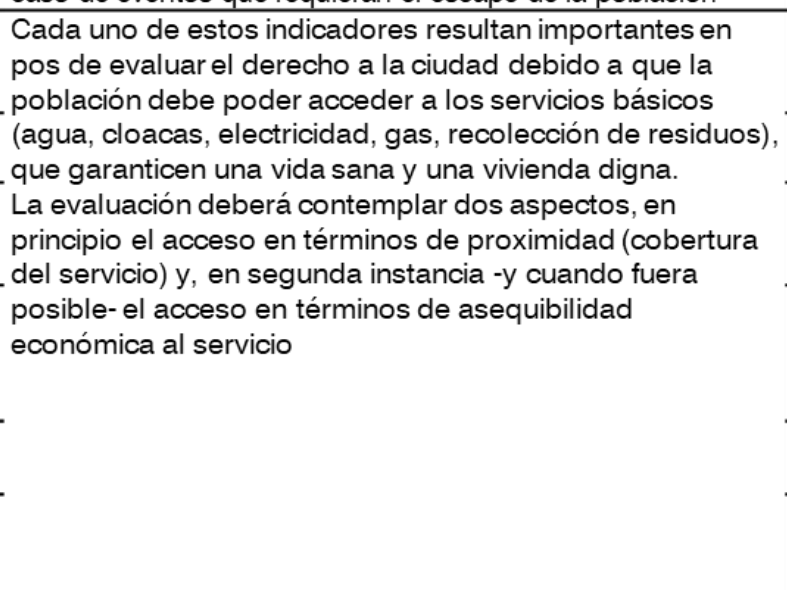 } & $\begin{array}{l}\text { ¿Existen redes cloacales en el área de estudio? ¿A qué } \\
\text { distancia se encuentran (en caso de que no se } \\
\text { observen en el sector)? }\end{array}$ & MICRO \\
\hline & & Agua Corriente & Se mide la existencia de agua corriente & & $\begin{array}{l}\text { ¿Qué acceso tiene la población del área de estudio al } \\
\text { servicio de agua corriente? }\end{array}$ & MICRO \\
\hline & & Electricidad & $\begin{array}{l}\text { Se mide la existencia de provisión de energía eléctrica por red } \\
\text { domiciliaria }\end{array}$ & & $\begin{array}{l}\text { ¿Qué acceso tiene la población del área de estudio al } \\
\text { sevicio de energía eléctrica? ¿Cuál es el área de } \\
\text { ç obertura de este servicio? }\end{array}$ & MICRO \\
\hline & & $\begin{array}{l}\text { Alumbrado } \\
\text { público }\end{array}$ & Se verifica la provisión del servicio de alumbrado público & & $\begin{array}{l}\text { ¿Qué acceso tiene la población del área de estudio al } \\
\text { servicio de alumbrado público? eTodeds las calles } \\
\text { posenen alumbrado? ¿O sólo se localiza sobre las } \\
\text { avenidas? }\end{array}$ & MICRO \\
\hline & & Gas & $\begin{array}{l}\text { Se mide la existencia de red de gas natural, que permita abastecer al } \\
\text { área de estudio. }\end{array}$ & & $\begin{array}{l}\text { ¿Qué acceso tiene la población del área de estudio al } \\
\text { senvicio de gas? }\end{array}$ & MICRO \\
\hline & & $\begin{array}{l}\text { Recolección de } \\
\text { residuos }\end{array}$ & $\begin{array}{l}\text { Se verifica la provisión del servicio de recolección de residuos, } \\
\text { considerando un mínimo de dos recolecciones por semana }\end{array}$ & & $\begin{array}{l}\text { ¿Qué accesoso tiene la población del área de estudio al } \\
\text { servicio de recolección de residuos? ¿Cuál es el área } \\
\text { de cobertura de este esvricio? }\end{array}$ & MICRO \\
\hline & & $\begin{array}{l}\text { Conectividad } \\
\text { Digital }\end{array}$ & $\begin{array}{l}\text { Con este indicador se procura evaluar el acceso de la población al } \\
\text { servicio de internet, a partir de estudiar la cobertura de este servicio }\end{array}$ & $\begin{array}{l}\text { El mundo globalizado actual hace necesario el acceso a la } \\
\text { conectividad digital, para el desarrollo de múltiples } \\
\text { actividades (admininstrativas, laborales, etc.), por eso resulta } \\
\text { relevante el análisis de la cobertura de la conectividad }\end{array}$ & $\begin{array}{l}\text { ¿Cuál es el radio de cobertura de la conectividad } \\
\text { digital? iLa población cuenta con acceso a redes Wifi } \\
\text { públicas y gratuitas? }\end{array}$ & MACRO \\
\hline & \multirow[t]{6}{*}{$\begin{array}{l}\text { DESARROLLO } \\
\text { SOCIAL }\end{array}$} & $\begin{array}{l}\text { Centros de Apoyo } \\
\text { a la Alimentación }\end{array}$ & $\begin{array}{l}\text { A partir del análisis de este indicador se procura evaluar el acceso a la } \\
\text { alimentación desde el territorio, verificando la existencia de centros de } \\
\text { apoyo a la alimentación }\end{array}$ & $\begin{array}{l}\text { Resulta fundamental evaluar este indicador debido a que la } \\
\text { alimentación adecuada está directamente relacionada con la } \\
\text { salud, y por ende, es fundamental evaluar -desdel los } \\
\text { aspectos territoriales- el acceso que tiene la población a } \\
\text { establecimientos que permitan satisfiacer estas necesidades } \\
\text { básicas }\end{array}$ & $\begin{array}{l}\text { ¿Existen centros a los cuales la población puede acudir } \\
\text { en caso de no tener acceso a las comidas básicas y } \\
\text { fundamentales (Copa de Leche, Centros de Atención } \\
\text { de organizaciones religiosas, etc)? }\end{array}$ & MICRO \\
\hline & & $\begin{array}{c}\text { Centros de } \\
\text { Referencia (CDR) }\end{array}$ & $\begin{array}{l}\text { El indicador procura evaluar la existencia de Centros de Referencia. Estos } \\
\text { espacios funcionan como sedes del Ministerio de Desarrollo Social y en ellos } \\
\text { se pueden desarrollar trámites como el del Monotributo Social, así como } \\
\text { otros programas y servicios del Ministerio }\end{array}$ & \multirow{5}{*}{$\begin{array}{l}\text { El análisis de estos indicadores se basa en el estudio de } \\
\text { - diferentes programas y servicicos administrados por el } \\
\text { Ministerio de Desarrollo Social, fundamentales para que la } \\
\text { población pueda acceder a servicios básicoss, así como a } \\
\text {-espacios para la formación; servicios destinados a que } \\
\text { todos los habitantes puedan mejorar su calidad de vida }\end{array}$} & $\begin{array}{l}\text { ¿Existen Centros de Referencia en el Área de Estudio? } \\
\text { ¿Son facilmente identificables para que la población } \\
\text { pueda acceder a ellos? ¿En qué sector se localizan? }\end{array}$ & MICRO \\
\hline & & $\begin{array}{l}\text { Centros } \\
\text { Integradores } \\
\text { Comunitarios } \\
\quad(\mathrm{CIC}) \\
\end{array}$ & $\begin{array}{l}\text { El indicador procura evaluar la existencia de Centros Integradores } \\
\text { Comunitarios, espacios que permiten la participación de la población en } \\
\text { diversas actividades (recreativas, educativas, formativas) y, en ocasiones, el } \\
\text { acceso a atención médica }\end{array}$ & & $\begin{array}{l}\text { ¿Existen Centros Integradores Comunitarios en el área } \\
\text { de estudio? iSon facimente identificables para que la } \\
\text { población puedá acceder a ellos? iEn qué sector se } \\
\text { localizan? ¿Qué actividades pueden desarrollarse en } \\
\text { ellos? }\end{array}$ & MICRO \\
\hline & & $\begin{array}{l}\text { Instituciones de } \\
\text { Microcrédito (IM) }\end{array}$ & $\begin{array}{l}\text { El indicador se orienta a reconocer la existencia de Instituciones de } \\
\text { Microcréditos que permiten que la población que posee un emprendimiento } \\
\text { de EEonomía Social, puedanacceder a microcréditos para la compra de } \\
\text { insumos, materiales y herramientas }\end{array}$ & & $\begin{array}{l}\text { ¿Existen Instituciones de Microcrédito en el área de } \\
\text { estudio? ¿En qué sector se localizan? }\end{array}$ & MICRO \\
\hline & & $\begin{array}{c}\text { Ferias } \\
\text { Permanentes (FP) }\end{array}$ & $\begin{array}{l}\text { A partir de este indicador se evalúa la presencia de Ferias Permanentes en el } \\
\text { área de estudio, siendo que se trata de espacios en los que la población } \\
\text { puede acceder a diferentes insumos y productos elaborados por } \\
\text { emprendedores locales }\end{array}$ & & $\begin{array}{l}\text { ¿Existen Ferias Permanentes en el área de estudio? } \\
\text { ¿En qué sector se localizan? ¿Qué tipo de productos se } \\
\text { ofrecen? }\end{array}$ & MICRO \\
\hline & & $\begin{array}{l}\text { ProHuerta }(\mathrm{PH}) \\
\end{array}$ & $\begin{array}{l}\text { Con este indicador se analiza la existencia de espacios ProHuerta en el área } \\
\text { de estudio; espacios en los que se puede accedder a a asesoramiento técnico, } \\
\text { insumos y capacitaciones para crear huertas familiaes o comunitarias }\end{array}$ & & $\begin{array}{l}\text { ¿Existen espacios destinados al programa ProHuerta } \\
\text { en el área de estudio? ¿En qué sector se localizan? }\end{array}$ & MICRO \\
\hline
\end{tabular}




\section{IGUALDAD ENTRE TODOS LOS HABITANTES}

Las ciudades deben garantizar la igualdad entre todos los habitantes, sin ningún tipo de discriminación, permitiendo y alentando la vida en comunidad

\begin{tabular}{|c|c|c|c|c|c|c|}
\hline VARIABLE & DIMENSIÓN & INDICADOR & DESCRIPCIÓN del INDICADOR & OBJETIVO de la MEDICIÓN & PREGUNTAS CONDUCTORAS & $\begin{array}{l}\text { ESCALA DE } \\
\text { ANALISIS }\end{array}$ \\
\hline \multirow{8}{*}{$\begin{array}{l}\text { CIUDAD } \\
\text { INTEGRADORA } \\
\text { El objetivo es } \\
\text { garantizar } \\
\text { igualdad de } \\
\text { condiciones } \\
\text { entre la } \\
\text { sociedad, y } \\
\text { fortalecer los } \\
\text { mecanismos } \\
\text { que permitan la } \\
\text { construcción } \\
\text { de una } \\
\text { ciudadanía } \\
\text { responsable y } \\
\text { activa, que } \\
\text { pueda } \\
\text { participar y } \\
\text { disfrutar de la } \\
\text { ciudad }\end{array}$} & \multirow[t]{3}{*}{$\begin{array}{l}\text { ACCESO AL } \\
\text { SUELO }\end{array}$} & Banco de Tierras & $\begin{array}{l}\text { Con el análisis de este indicador se busca verificar si el } \\
\text { Estado posee bancos de tierras que puedan responder a la } \\
\text { demandanda habitacional ya d déficiti trbano habitacional, } \\
\text { entendiendo por tal a "la escasez, calidad insuficiente o } \\
\text { inaccesibilidad a condiciones materiales, servicios y espacios } \\
\text { aptos para satisfacer las necesidades y promover una mejor } \\
\text { calidad de vida de la población en el marco de un hábitat } \\
\text { ambientalmente sostenible" }\end{array}$ & $\begin{array}{l}\text { Pese a que existen diversas formas de actuar ante el déficit urbano } \\
\text { habitacional, la creación y existencia de bancos de tierra permiten el } \\
\text { desarrollo de planes de vivienda u otros espacios necesarios para } \\
\text { el desarrollo de la vida en comunidad (espacios recreativos, } \\
\text { complejos deportivos, complejos educativos, entre otros), } \\
\text { tendiendo a la integración social y la cohesión social en una ciudad, } \\
\text { por eso resulta relevante el análisis de este indicador }\end{array}$ & $\begin{array}{l}\text { ¿El Estado ha constituido bancos de } \\
\text { tierra en el sector? ¿Posee terrenos } \\
\text { que puedan utilizarse para satisfacer } \\
\text { las demandas habitacionales del área } \\
\text { de estudio? }\end{array}$ & MACRO \\
\hline & & Planes de Vivienda & $\begin{array}{l}\text { A partir de este indicador se observa la existencia de } \\
\text { viviendas desarrollados por el Estado en el sector de análisis, } \\
\text { así como las características principales de estos planes de } \\
\text { vivienda }\end{array}$ & $\begin{array}{l}\text { Se trata de un indicador de gran relevancia en el marco del derecho } \\
\text { a l a ciudad y, específicamente, en relación a este principio de } \\
\text { garantizar una ciudad integradora que facilite la igualdad entre } \\
\text { todos sus habitantes; debido a que el acceso a la vivienda es uno } \\
\text { de los principales factores de segregación en las ciudades. Cabe } \\
\text { destacar que no es simplemente el acceso a una vivienda (a un } \\
\text { techo, sino que deben contemplarse otros factores que hacen al } \\
\text { hábitat. Pese a esto, las actuaciones en torno a garantizar la } \\
\text { vivienda resultan estratégicas para evitar la exclusión social y } \\
\text { garantizar la integración de los habitantes }\end{array}$ & $\begin{array}{l}\text { ¿La demanda de vivienda se } \\
\text { satisface en el sector a partir de la } \\
\text { construcción y el desarrollo de } \\
\text { planes de vivienda?; iqué tipo de } \\
\text { planes de vivienda se desarrollan?; } \\
\text { isólo se construyen viviendas o hay } \\
\text { otros desarrollos (espacio público, } \\
\text { áreas de recreación, áreas } \\
\text { destinadas a educación, salud, } \\
\text { etc.)?; ien qué área se localizan los } \\
\text { planes de vivienda? }\end{array}$ & MICRO \\
\hline & & Valor del Suelo & $\begin{array}{l}\text { Con este indicador se procura medir el valor del suelo por } \\
\text { manzanas para evaluar la posibilidad de acceder a un terreno } \\
\text { y una vivienda digna en el área de estudio }\end{array}$ & $\begin{array}{l}\text { La importancia de evaluar el valor del suelo, y asociarlo a los } \\
\text { ingresos promedio de la población, resulta de vital importancia y } \\
\text { retomando el concepto de las ciuddades injustas planteado en el } \\
\text { marco teórico, se entiende que resulta relevante el estudio de este } \\
\text { indicador en pos de indagar en la capacidad de los habitantes de } \\
\text { acceder a un terreno o vivienda propia, favoreciendo la integración } \\
\text { de los ciudadanos y su inserción en contextos urbanos }\end{array}$ & $\begin{array}{l}\text { ¿Cuál es el valor del suelo promedio } \\
\text { en el área de estudio? ¿Se trata de } \\
\text { terrenos accesibles para la } \\
\text { población? ¿Cómo se relaciona con } \\
\text { el ingreso promedio de la población? }\end{array}$ & $\begin{array}{l}\text { MACRO y } \\
\text { MICRO }\end{array}$ \\
\hline & \multirow[t]{4}{*}{ VIVIENDA } & Tipo de Vivienda & $\begin{array}{l}\text { El indicador tiene como objetivo dar cuenta de las } \\
\text { condiciones en las que se encuentran las viviendas, } \\
\text { asignando un valor a cada tipo de vivienda (de acuerdo a los } \\
\text { parámetros del Censo Nacional), definiendo situaciones } \\
\text { óptimas y deficitarias }\end{array}$ & \multirow{3}{*}{$\begin{array}{l}\text { Teniendo en cuenta que las viviendas deben tener condiciones } \\
\text { dignas para poder habitar en ellas, resultan indicadores } \\
\text { fundamentales que reconocen, entre otras cuestiones, las } \\
\text { características principales de las mismas (en relación a la } \\
\text { materialidad de sus paredes, pisos y techo, entre otros aspectos). } \\
\text {-Así, se evaluarán las viviendas, desde aquellas más aptas para el } \\
\text { habitar, hasta las menos aptas }\end{array}$} & $\begin{array}{l}\text { ¿Cuáles son las condiciones de la } \\
\text { vivienda? ¿Se trata de una vivienda } \\
\text { tipo A, B? ¿Son ranchos o casillas? }\end{array}$ & MICRO \\
\hline & & $\begin{array}{l}\text { Cantidad de } \\
\text { Habitantes }\end{array}$ & $\begin{array}{l}\text { Se mide la cantidad de habitantes que ocupan una vivienda, a } \\
\text { fin de reconocer si se observa o no hacinamiento en los } \\
\text { hogares }\end{array}$ & & $\begin{array}{l}\text { ¿Cuántos habitantes ocupan la } \\
\text { vivienda? ¿Se observan } \\
\text { características de hacinamiento? }\end{array}$ & MICRO \\
\hline & & $\begin{array}{l}\text { Hogares con } \\
\text { Necesidades Básicas } \\
\text { Insatisfechas }\end{array}$ & $\begin{array}{l}\text { Apunta al reconocimiento de "Hogares con Necesidades } \\
\text { Básicas Insatisfechas", entendiendo a los mismos como } \\
\text { aquellos hogares en los que se observa al menos una } \\
\text { condición de privación de algún tipo (vivienda, condiciones } \\
\text { sanitarias, hacinamiento, asistencia escolar, capacidad de } \\
\text { subsistencia) }\end{array}$ & & $\begin{array}{l}\text { ¿Cuáles son las condiciones de la } \\
\text { población en relación a las } \\
\text { Necesidades Básicas? ¿Qué } \\
\text { características se observan en el } \\
\text { territorio en relación a este indicador? }\end{array}$ & $\begin{array}{l}\text { MACRO } \\
\text { y MICRO }\end{array}$ \\
\hline & & Regimen de Tenenc & $\begin{array}{l}\text { Se evalúa la condición de tenencia de la vivienda (si se trata } \\
\text { de propietarios, inquilinos o hay condiciones de ocupación } \\
\text { informal) }\end{array}$ & $\begin{array}{l}\text { Resulta importante reconocer esta cuestión ya que la tenencia de la } \\
\text { propiedad garantiza el derecho al arraigo en un lugar (no sólo a la } \\
\text { vivienda), un derecho fundamental a garantizar en el marco del } \\
\text { Derecho a la Ciudad }\end{array}$ & $\begin{array}{l}\text { ¿Cuál es la condición de tenencia de } \\
\text { las viviendas? ¿Son propietarios? } \\
\text { ¿Son inquilinos? ¿Otro tipo (tenencia } \\
\text { irregular)? }\end{array}$ & MICRO \\
\hline & $\begin{array}{l}\text { FORMACION } \\
\text { PROFESIONAL }\end{array}$ & $\begin{array}{l}\text { Centros de } \\
\text { Formación } \\
\text { Profesional / Oficios }\end{array}$ & $\begin{array}{l}\text { Observar la existencia de centros de formación profesional } \\
\text { gratuita en el área de estudio }\end{array}$ & $\begin{array}{l}\text { Es importante estudiar el acceso de la población a estos centros } \\
\text { por diversas cuestiones, pero fundamentalmente porque capacitar a } \\
\text { la población permite fortalecer la construcción de ciudadanía, factor } \\
\text { fundamental para que los ciudadanos pueda exigir y hacer valer sus } \\
\text { derechos }\end{array}$ & $\begin{array}{l}\text { ¿Existen centros de formación } \\
\text { profesional y en oficios, a los cuales } \\
\text { la población del área de estudio } \\
\text { pueda acceder de forma gratuita? } \\
\text { ¿Son estos suficientes para satisfacer } \\
\text { la demanda y abastecer a la } \\
\text { población? }\end{array}$ & $\begin{array}{l}\text { MACRO } \\
\text { y MICRO }\end{array}$ \\
\hline
\end{tabular}




\section{RESPETO POR EL MEDIO AMBIENTE}

Las ciudades deben fomentar procesos ordenados de ocupación del territorio, procurando proteger las áreas ambientalmente vulnerables y recursos fundamentales para la vida

\begin{tabular}{|c|c|c|c|c|c|c|}
\hline VARIABLE & DIMENSIÓN & INDICADOR & DESCRIPCIÓN del INDICADOR & OBJETIVO de la MEDICIÓN & PREGUNTAS CONDUCTORAS & $\begin{array}{l}\text { ESCALA DE } \\
\text { ANALISIS }\end{array}$ \\
\hline \multirow{5}{*}{$\begin{array}{l}\text { CIUDAD } \\
\text { sosTENIBLE } \\
\text { El objetivo es } \\
\text { generar una } \\
\text { ciudad } \\
\text { habitable, } \\
\text { saludable, } \\
\text { segura y } \\
\text { disfrutable, } \\
\text { que permita } \\
\text { el uso de los } \\
\text { recursos } \\
\text { naturales sin } \\
\text { agotarlos en } \\
\text { el tiempo } \\
\text { presente, y } \\
\text { preservando } \\
\text { la naturaleza } \\
\text { para las } \\
\text { generaciones } \\
\text { actuales y } \\
\text { futuras }\end{array}$} & \multirow[t]{2}{*}{ IDEA DE CIUDAD } & $\begin{array}{l}\text { Legislación } \\
\text { sobre Usos } \\
\text { del Suelo }\end{array}$ & $\begin{array}{l}\text { Se busca analizar la existencia de normativas que } \\
\text { definan el destino de la ciudad, la "idea de ciudad" } \\
\text { que se pretende alcanzar. }\end{array}$ & $\begin{array}{l}\text { La importancia de analizar este aspecto } \\
\text { radica en la necesidad de definir un modelo } \\
\text { hacia el cual la ciudad debe tender, que } \\
\text { considere aspectos fundamentales que } \\
\text { permitan el desarrollo de una vida de } \\
\text { calidad a todos los habitantes }\end{array}$ & $\begin{array}{l}\text { ¿Qué usos del suelo se definen en la } \\
\text { legislación? ¿Se respetan estos usos o se } \\
\text { observa incompatibilidad de usos? ¿Hay } \\
\text { limitaciones para preservar el ambiente y } \\
\text { los recursos naturales del área? }\end{array}$ & MACRO \\
\hline & & $\begin{array}{l}\text { Legislación } \\
\text { Energías } \\
\text { Sostenibles }\end{array}$ & $\begin{array}{l}\text { Observar la existencia de legislación en materia } \\
\text { del uso de energías renovables que sean } \\
\text { aplicables al área de estudio }\end{array}$ & $\begin{array}{l}\text { Coincidentemente con la concepción de } \\
\text { una ciudad sostenible, que permita el } \\
\text { desarrollo no sólo de las generaciones } \\
\text { actuales sino también de las generaciones } \\
\text { futuras y que procure -a tal fin- el cuidado } \\
\text { de los recursos naturales, resulta relevante } \\
\text { estudiar si se ha desarrollado legislación en } \\
\text { relación al uso de energías renovables, y si } \\
\text { este tipo de energías se aplica en el área } \\
\text { de estudio }\end{array}$ & $\begin{array}{l}\text { ¿Se ha desarrollado legislación en relación } \\
\text { al uso de energías renovables? ¿Se aplica } \\
\text { el uso de estas energías? ¿En qué sector } \\
\text { del área de estudio? }\end{array}$ & MACRO \\
\hline & \multirow[t]{3}{*}{$\begin{array}{l}\text { RIESGOS } \\
\text { AMBIENTALES }\end{array}$} & $\begin{array}{c}\text { Industrias } \\
\text { Contaminantes }\end{array}$ & \multicolumn{2}{|c|}{$\begin{array}{l}\text { El indicador apunta a observar la existencia de industrias contaminantes en el sector, y las } \\
\text { características de estas (en términos del grado de contaminación que generan) y, } \\
\text { fundamentalmente, la localización de las mismas, a fin de reconocer si se localizan en áreas } \\
\text { destinadas a estos fines, protegiendo a la población de los efectos que pudieran generar }\end{array}$} & $\begin{array}{l}\text { ¿Existen industrias en el área de estudio? } \\
\text { ¿De qué tipo? ¿Hay industrias de 3er tipo? } \\
\text { ¿Se encuentran dentro de las áreas } \\
\text { definidas como "zona industrial"? }\end{array}$ & MICRO \\
\hline & & $\begin{array}{l}\text { Riesgo } \\
\text { Hídrico }\end{array}$ & $\begin{array}{l}\text { Con el análisis de este indicador se buscar } \\
\text { verificar la existencia de sectores en condición de } \\
\text { riesgo hídrico en el área de estudio }\end{array}$ & $\begin{array}{l}\text { Resulta fundamental la indagación en } \\
\text { relación a este indicador, debido a que el } \\
\text { fenómeno de las inundaciones ha sido una } \\
\text { constante en los últimos tiempos, } \\
\text { generando tanto pérdidas materiales como } \\
\text { humanas; y el conocimiento de estas } \\
\text { cuestiones permite la intervención en pos } \\
\text { de mitigar esta problemática }\end{array}$ & $\begin{array}{l}\text { ¿El área de estudio presenta zonas con } \\
\text { riesgo hídrico? ¿Qué superficie abarca? } \\
\text { ¿Cuánta población se encuentra asentada } \\
\text { en estas zonas? }\end{array}$ & MICRO \\
\hline & & Cavas & $\begin{array}{l}\text { Observar la existencia de explotaciones } \\
\text { orientadas a la actividad extractiva (generando } \\
\text { cavas) en el área de estudio }\end{array}$ & $\begin{array}{l}\text { Resulta un aspecto fundamental a } \\
\text { considerar, ya que la actividad extractiva } \\
\text { (cavas), genera riesgos ambientales a la } \\
\text { población debido a la extracción de suelo } \\
\text { productivo, a la contaminación de las } \\
\text { napas y a la fragilidad ambiental y territorial } \\
\text { que genera en su entorno }\end{array}$ & $\begin{array}{l}\text { ¿Se observa la presencia de cavas en el } \\
\text { área de estudio? ¿Qué superficie del área } \\
\text { ocupan? ¿Hay población asentada en las } \\
\text { cercanías de las mismas? }\end{array}$ & MICRO \\
\hline
\end{tabular}




\section{USUFRUCTO EQUITATIVO DE LAS CIUDADES}

Las ciudades deben ofrecer las condiciones para que todos los habitantes puedan hacer uso y gozar de los recursos que éstas ofrecen, generando espacios urbanos que estimulen el encuentro, el intercambio y la expresión de los ciudadanos

\section{VARIABLE DIMENSIÓN INDICADOR DESCRIPCIÓN del INDICADOR}

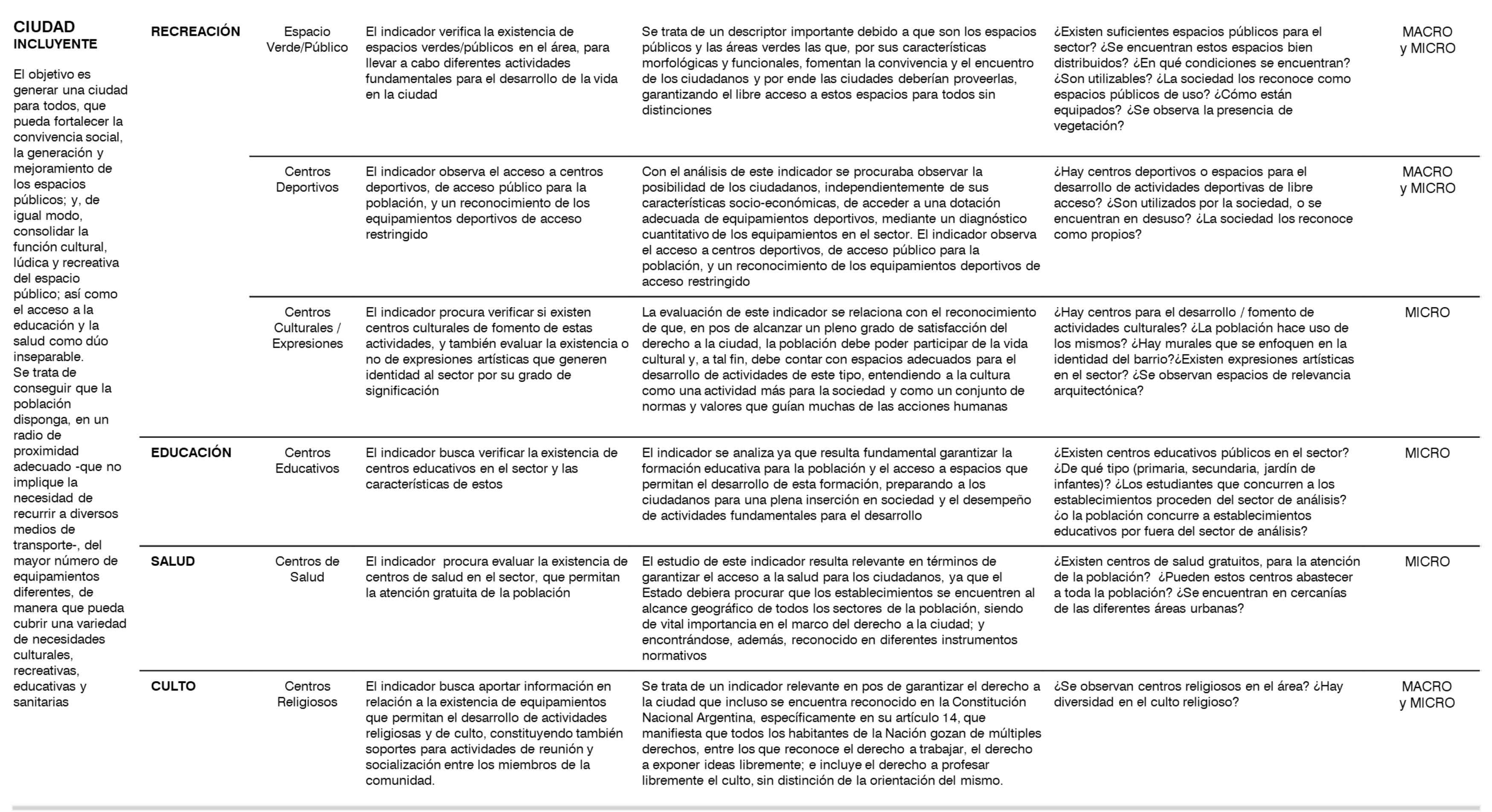




\section{CAPÍTULO 4 | APLICACIÓN METODOLÓGICA. VARIABLE CIUDAD INCLUYENTE}

"Todas las personas tienen el derecho de encontrar en la ciudad las condiciones necesarias para su realización política, económica, cultural, social y ecológica, asumiendo el deber de la solidaridad"

(Carta Mundial del Derecho a la Ciudad, 2005)

El cuarto capítulo se enfocó en la aplicación metodológica de una de las variables construidas -Ciudad Incluyente-, sus dimensiones e indicadores, en un área de estudio determinada, correspondiente a un recorte de una ciudad intermedia como es la localidad de Punta Lara. A tal fin, se describió brevemente el contexto territorial de estudio (desde una escala general hasta una escala micro), para luego desarrollar el ensayo propiamente dicho.

Cabe destacar que la focalización en una de las variables se realiza por cuestiones operativas y de condiciones de realización de la presente tesis y, por este motivo, no debe entenderse como una omisión del carácter integral -presente en la metodología elaborada- con que se concibe tanto al territorio -en que se inscribe el caso Punta Lara-, como al Derecho a la Ciudad -del que forma parte la variable Ciudad Incluyente.

\subsection{El área de estudio}

El abordaje de la investigación se desarrolló a partir de escalas diferentes, que permitieron un acercamiento gradual a la unidad territorial de aplicación de la metodología. Así, se adoptó, la microrregión del Gran La Plata como contexto general de la investigación, el partido de Ensenada como contexto macro, y una tercera escala de abordaje -escala micro de aplicación de la metodología-, constituida por la unidad territorial del recorte de la localidad de Punta Lara (Figura 11).

Se adoptó este recorte territorial de la localidad para el desarrollo de la presente investigación, por diferentes cuestiones. En principio, como ya fuera identificado, debido a que las problemáticas inherentes al tema de estudio pueden verse representadas en la misma.

Además, porque en términos espaciales el recorte es claro en esta subcentralidad de la localidad de Punta Lara, constituyendo un enclave que presenta una variedad de situaciones interesantes para el abordaje y la aplicación metodológica: una localidad costera con situaciones de vulnerabilidad y riesgo ambiental pero oportunidades en términos del desarrollo y oferta turística, con un proceso de crecimiento y expansión sostenido en el tiempo, en un enclave aislado del partido, pero a la vez con una conexión franca e interrelación directa con el partido de Ensenada y el partido de La Plata; y con una creciente intervención del Estado municipal en el proceso de planificación del territorio, entre otras cuestiones. 


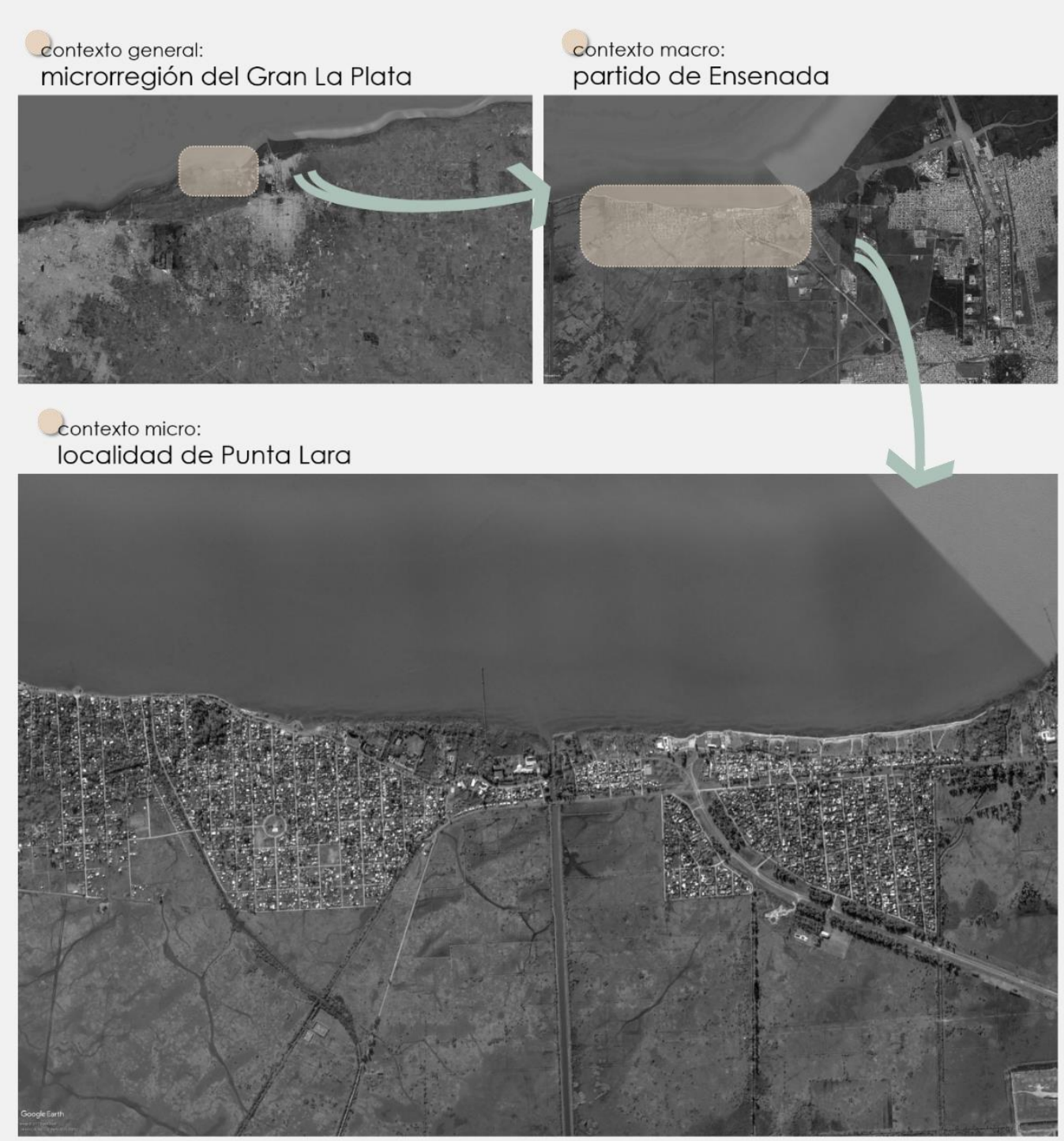

Figura 11. Escalas de abordaje de la investigación. Elaboración propia. 2019

\subsection{1 | El contexto general de la investigación. La microrregión del Gran La Plata}

El contexto marco de la investigación -como se definió previamente- está constituido por la microrregión del Gran La Plata, en la Provincia de Buenos Aires, conformada a partir de tres partidos: el Partido de La Plata, el Partido de Ensenada y el Partido de Berisso.

Se lo reconoce como un ente microrregional, debido a que, pese a que cada uno de los municipios pertenece a jurisdicciones diferentes y presenta características diferenciales, pueden asociarse en términos de funcionalidad y homogeneidad ${ }^{12}$.

\footnotetext{
${ }^{12}$ Según Francisco Rodríguez Barrientos (2007), "La homogeneidad hace referencia a cierta uniformidad y extensión en diversas características de la (micro) región, como las físicas (topografía, régimen de lluvias, hidrografía, clima, etc.); económicas (sistemas productivos, tipos de productos prevalecientes o más relevantes); y socioculturales (idioma, religión, etnicidad, entre otros)". En relación al concepto de "funcionalidad", sostiene que "involucra el modo de interrelación espacial y alude especialmente a la funcionalidad socioeconómica de una región (importancia de la acción institucional; extensión del mercado como mecanismo económico de regulación económica y de asignación de recursos; capacitación de la mano de obra; niveles educativos)"
} 
En este sentido, a nivel nacional, puede observarse que la región de estudio pertenece a la franja central del país (Figura 12), que -según datos del Plan Estratégico Territorial realizado por la Subsecretaría de Urbanismo y Vivienda en el año 2011- presenta un mayor abastecimiento en materia de infraestructura de servicios básicos y de circulación y conectividad, así como en materia de equipamientos. Esta condición genera una atracción para la población que, en términos territoriales, se expresa en la expansión de los núcleos estructurantes de la región y en problemáticas relacionadas al transporte, el abastecimiento, la contaminación ambiental y la competitividad económica. De esta manera, las actividades productivas principales que se desarrollan en el área se asocian tanto a la agricultura y la ganadería, como a las actividades portuarias.

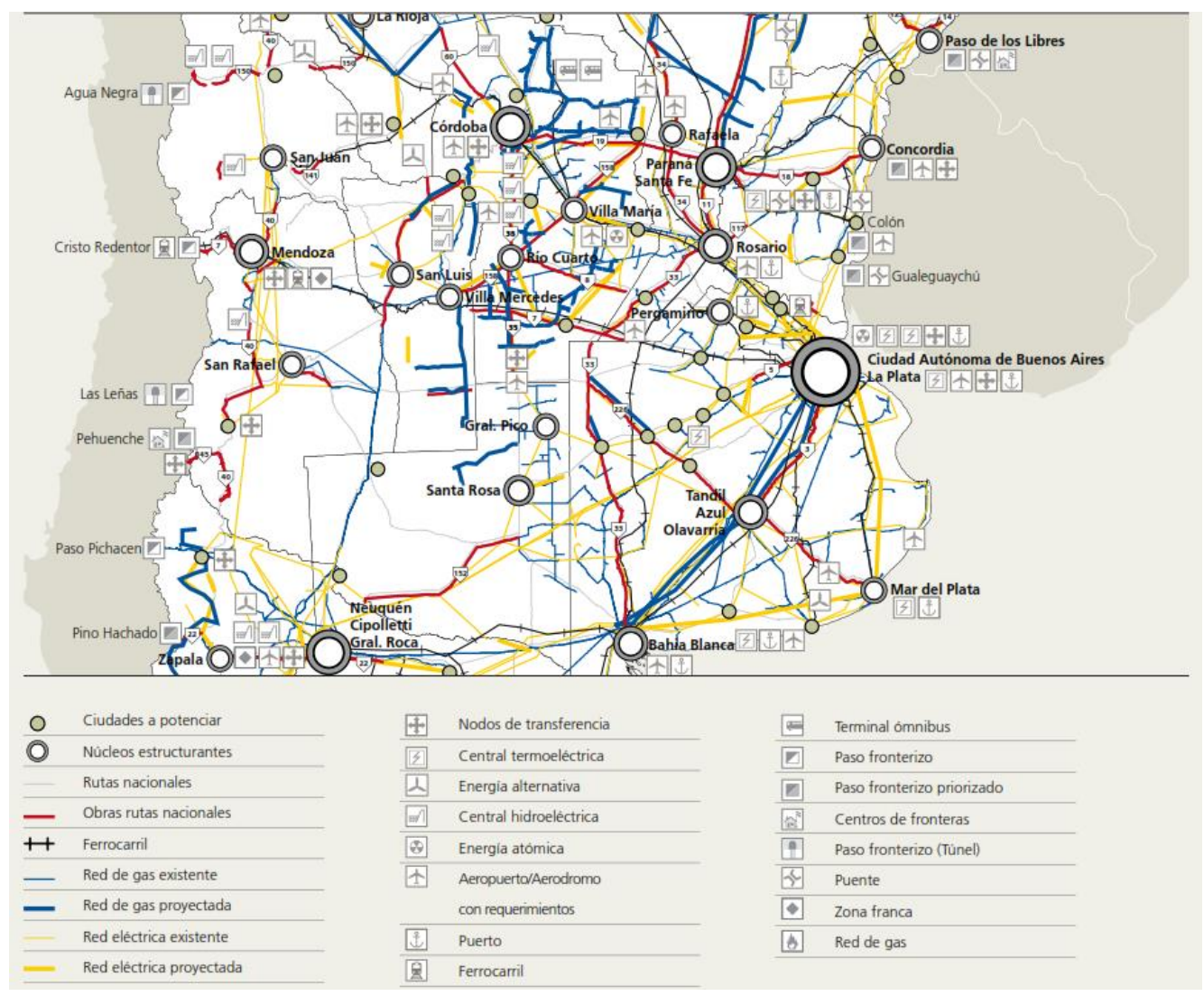

Figura 12. Mapa Franja de Proyectos Estratégicos Centro. Fuente: Plan Estratégico Territorial. Libro 2 "Territorio e Infraestructura". Subsecretaría de Urbanismo y Vivienda. Dirección Provincial de Ordenamiento Urbano y Territorial. Dirección de Planificación Urbana. 2011

A nivel regional, analizar la inserción contextual del Gran La Plata conlleva, necesariamente, comprenderla como parte de un sistema regional mayor, conocido como Región Metropolitana de Buenos Aires (RMBA). Inicialmente, al conformarse la región metropolitana de Buenos Aires no se consideraba al Gran La Plata como parte de ella, debido a que no presenta una continuidad en el sentido de conurbación. Sin embargo, las dinámicas de crecimiento y las relaciones que hoy en día se establecen entre ambas (a nivel de estructuras circulatorias, movimiento de población, dinámicas de empleo, entre otras), permiten considerar al Gran La Plata como una parte constituyente y articulada de esta región; más aún si se observa el crecimiento -en términos de ocupación territorial- que han tenido ambas, a pesar de que aún conservan características particulares y propias.

De acuerdo a datos del Censo 2010, se estima que la región Buenos Aires-Gran La Plata posee una población de alrededor de 15.000.000 de habitantes, lo que representa aproximadamente el 36\% de la población total del país; con lo cual las dinámicas, procesos y transformaciones que se producen en esta región son estructurantes. 


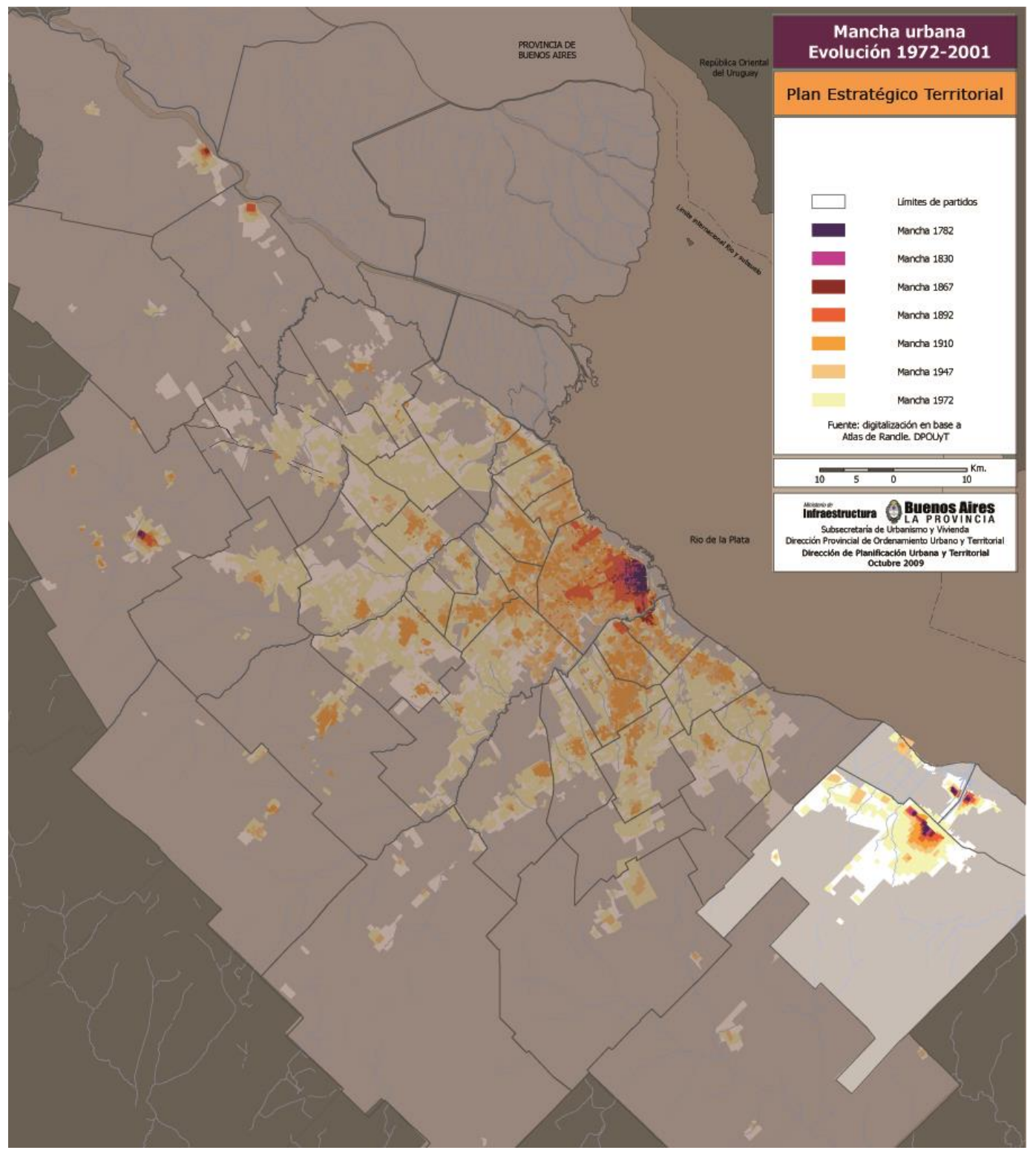

Figura 13. Mancha urbana. Evolución 1972-2001. Fuente: Plan Estratégico Territorial. Subsecretaría de Urbanismo y Vivienda. Dirección Provincial de Ordenamiento Urbano y Territorial. Dirección de Planificación Urbana y Territorial. Octubre 2009

En términos poblacionales, el Gran La Plata específicamente concentra 799.523 habitantes según el Censo Nacional de Población, Hogares y Viviendas del año 2010. De este total, 654.324 habitantes residen en La Plata, 88.470 en Berisso, y 56.729 en Ensenada ${ }^{13}$; lo que representa un total de 266.205 hogares (Tabla 1). 


PARTIDO
POBLACIÓN

Tabla 1. Población total y Cantidad de Hogares. Relación entre ambos factores. Elaboración propia. Fuente: Censo Nacional de Población, Hogares y Viviendas. 2010

Como puede observarse, la región ha presentado un crecimiento importante (Figura 13), particularmente durante los últimos años. Específicamente el Gran La Plata, ha manifestado una expansión urbana sobre el sector norte, y sobre las principales vías de circulación en forma tentacular, sin un proceso de ordenamiento aparente, sumado a un crecimiento en la densidad de ocupación.

\subsection{2 | El contexto macro. El partido de Ensenada}

El partido de Ensenada se encuentra sobre la costa del Río de La Plata, concentrando una población de aproximadamente 56.729 habitantes, que se encuentran distribuidos principalmente en tres localidades: la zona centro (Ensenada), en la que se encuentra la mayor concentración de población y se localiza el aparato administrativo y dos periféricas que son la zona costera (Punta Lara) y la zona del Dique.

En cuanto a la economía del partido, las principales actividades económicas son las relacionadas con los hidrocarburos y la petroquímica, a las que se suma el funcionamiento del puerto. La presencia de las industrias y el polo petroquímico tiene una gran impronta en el Partido, siendo las máximas generadoras de empleo y PBI (Producto Bruto Interno) en la zona, pero produciendo a la vez situaciones desfavorables para el partido que se relacionan con la contaminación, no sólo de las napas freáticas sino también del aire y los suelos de la región.

En relación a la condición del medio natural en el que se asienta, este se caracteriza por una singular fragilidad, dada por la conformación de sus suelos (bañados, llanuras de fango, playa) y, además, un gran número de arroyos y canales surcan la localidad, como el Canal Oeste, el Arroyo Miguelín, y otros elementos hidrográficos, justamente debido a su localización en la ribera del Río de La Plata. 


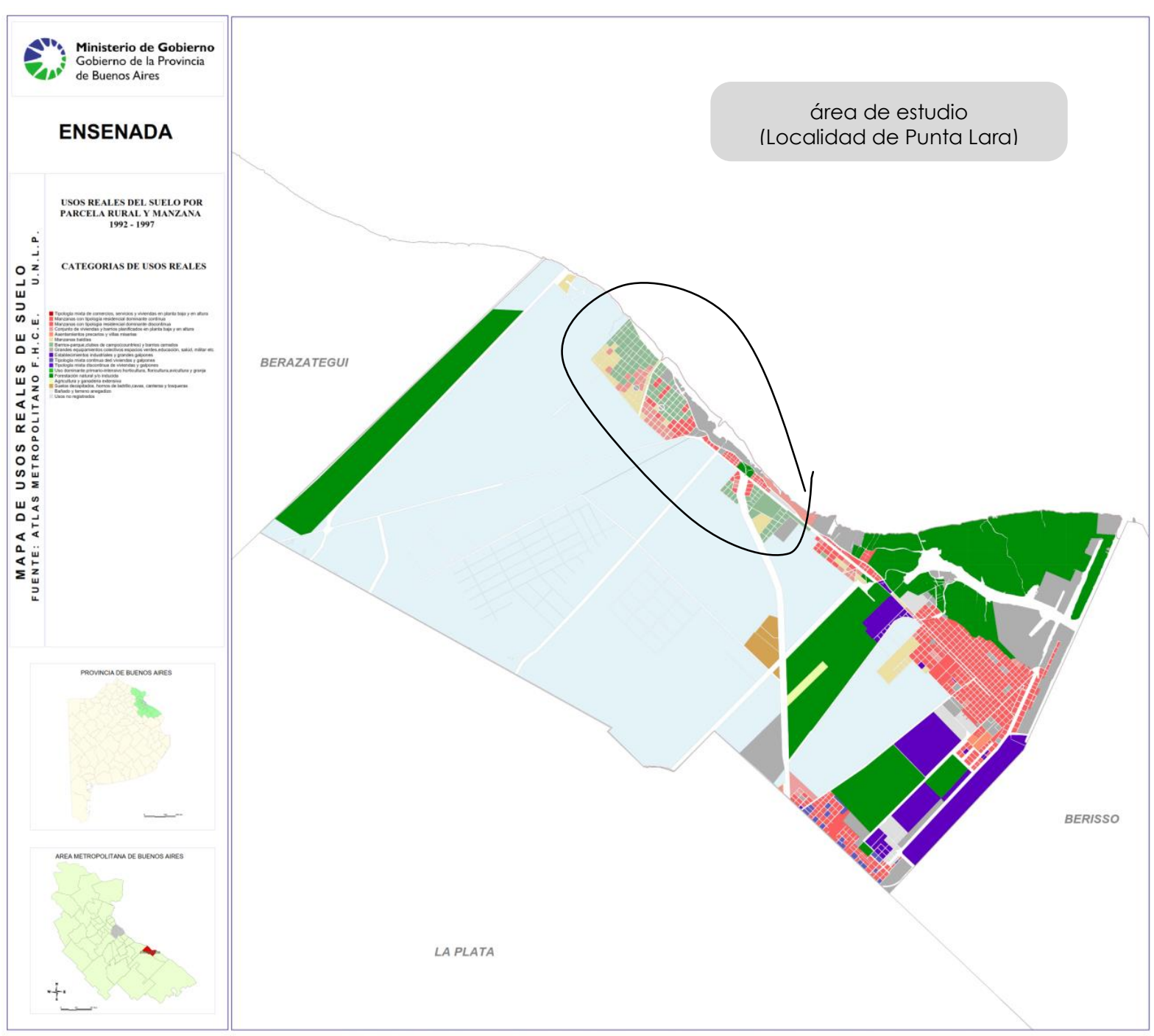

Figura 14. Mapa de Usos Reales del Suelo, Ensenada. Fuente: Ministerio de Gobierno de la Provincia de Buenos Aires. Atlas Metropolitano. F.H.C.E. U.N.L.P

El área de estudio, en general, se caracteriza por espacios abiertos de alta calidad paisajística, con abundante vegetación y cursos de agua, con subcentralidades urbanas que aparecen conectadas por las vías de circulación, constituyendo un paisaje singular dentro de un conglomerado urbano metropolitano.

\subsection{3 | El contexto micro. La localidad de Punta Lara}

La localidad de Punta Lara se encuentra en el Partido de Ensenada, caracterizado brevemente en el apartado anterior. Se trata de una localidad costera de rasgos particulares -debido a las relaciones territoriales que establece tanto con las localidades del partido, como con otras regiones, y a sus características naturales-, con un proceso de conformación histórica que comienza a gestarse durante las últimas décadas del 1800, a partir de las primeras estancias que se nuclean en torno a la zona de la estación del ferrocarril que conectaba a la ciudad de Buenos Aires con el puerto de Ensenada.

Así, en el año 1801 se realiza la fundación del núcleo originario de la localidad de Ensenada, con un proceso de ocupación lento y progresivo. Tal es así que las primeras ocupaciones en el área costera se dieron recién en el año 1922, cuando Martín Taylor obtuvo una serie de parcelas y el permiso para instalar un balneario público en Punta Lara. A partir de allí, se sumaron muchos otros emprendimientos, y para la década del '30 este tipo de instalaciones se transformaron en una característica del sector, conformando un núcleo turístico en la localidad de Punta Lara. 
De esta forma, el mayor impulso se evidenció con la instalación del Jockey Club en la localidad. Este inauguró su sede y donó algunos de los edificios más importantes de la localidad como la iglesia, la comisaría y una unidad sanitaria, la sede bancaria, un "Colegio de Señoritas" y el "Círculo de Periodistas". Seguidamente se establecieron el Automóvil Club Argentino y otros recreos, los que terminaron de asentar al nuevo destino recreativo y turístico, dando lugar a la instalación de población estable en la localidad. Se construyó, además, el camino costanero -Camino Costanero Almirante Brown-, lo que permitió la conexión con la capital provincial, La Plata y, a partir de allí, con otras localidades de la región.

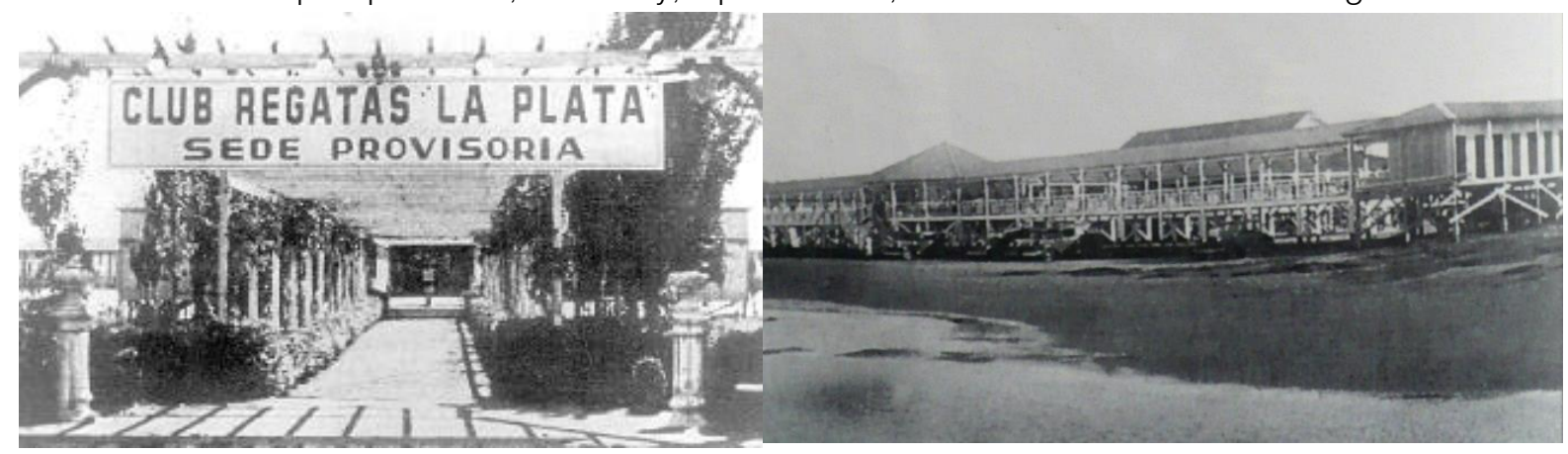

Figura 15. Imágenes históricas de espacios recreativos de la costa de Punta Lara. Imágenes obtenidas del Archivo Histórico del Ministerio de Obras Públicas de la Provincia de Buenos Aires. 2011

La década del '40 significó un nuevo impulso para la localidad de Punta Lara, debido a que se realizaron concesiones con diferentes sindicatos de trabajadores, que condujeron a la instalación de edificios y la adecuación de los espacios costeros para el desarrollo de actividades turísticas y recreativas en el sector, principalmente para sus asociados.

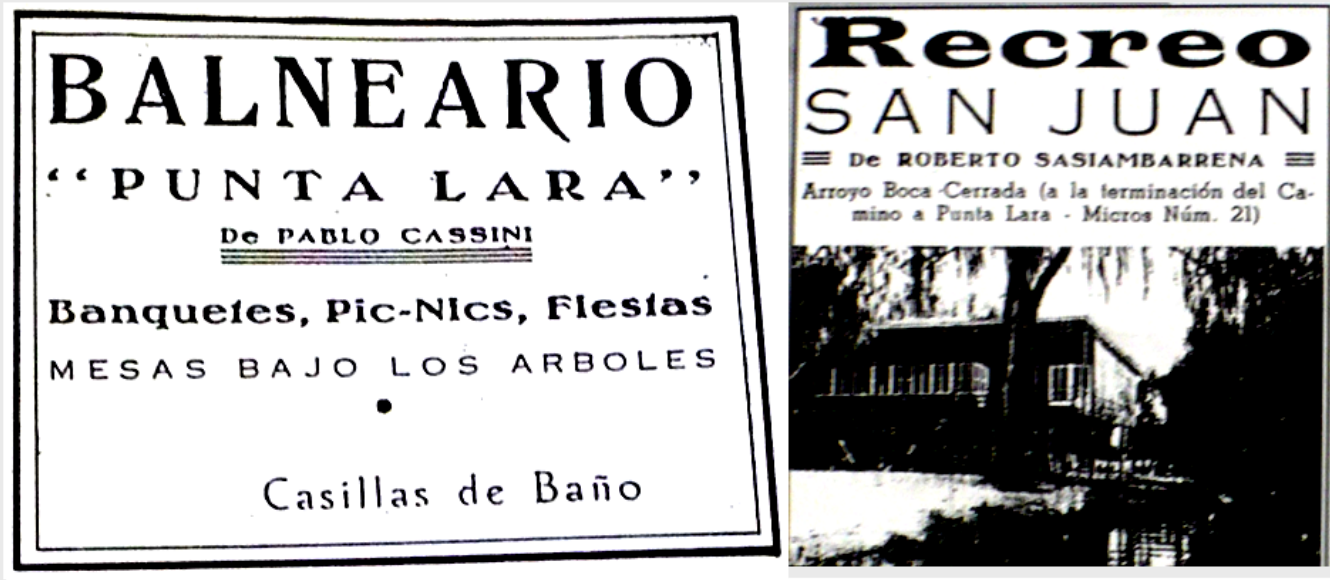

\section{BALNEARIO PUNTA LARA}

El aitio predilecto para las excursiones veraniegas.

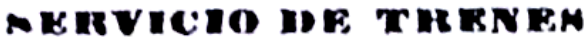

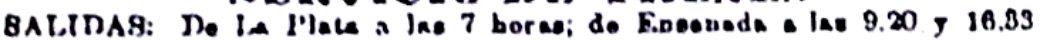

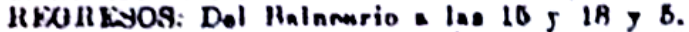

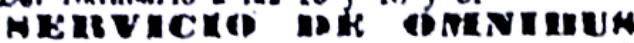

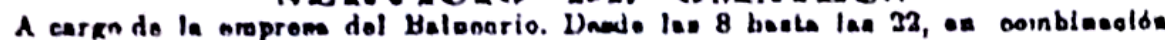
cos In llinea de traovian N. 4.

Comodidaden pars pic-nic, banquetes y toda clane de eciricios ecoodmicon para las famllias excuratoniatan. Concesionario: Martin Taylor 
Luego de estos años de gran desarrollo para la localidad, durante la década del '70 se produjeron una serie de crisis -entre ellas la suspensión del servicio de ferrocarril- que detuvieron el impulso del proceso de ocupación. Hacia finales de esta década, Punta Lara se recuperó en cierta medida gracias a algunas instituciones privadas que compraron los terrenos de los antiguos balnearios y se establecieron definitivamente. Sin embargo, estas iniciativas no apuntaron a generar un turismo general y el crecimiento de la localidad, sino que lo hacían en pos de su propio beneficio, lo que generó una suspensión de las iniciativas de recuperación de Punta Lara como destino turístico masivo.

Otro impulso que tuvo la región se produjo durante la década del '80, con el loteo y promoción de una zona al Sureste de la localidad, conocida en la actualidad como Villa del Plata. Muchos vecinos de la región, apostaron por esta zona caracterizada por una gran cantidad de vegetación y la cercanía del río como espacio recreativo y paisajístico. Así, se instalaron en este sector y construyeron viviendas con características de segunda residencia, muchas de las cuales se transformaron en residencias permanentes con el paso del tiempo. Sin embargo, estos breves impulsos de la localidad se vieron afectados por las sucesivas crisis de los años ' 80 y ' 90 , sumadas a las inundaciones de 1989 y 1990 que causaron serios destrozos, provocaron el abandono e incluso desmantelamiento de los balnearios y grandes edificios.

El proceso de ocupación del territorio continuó dándose progresivamente hacia el sector suroeste, ocupándose loteos que se encontraban subdivididos hace tiempo, pero se hallaban vacantes, alcanzando los bordes de las áreas rurales y sorteando algunas limitaciones del medio natural (como la Reserva Natural en el sector Noroeste). Esto se vio potenciado, además, por un proceso de ocupación informal por parte de población de bajos recursos que encontró en estos intersticios territoriales vacantes la posibilidad de acceder al suelo urbano, pese a tratarse de áreas que aún no cuentan con los servicios de infraestructura básicos (cloaca, electricidad, agua), y que se reconocen como parte del Registro Nacional de Barrios Populares (Figura 17).

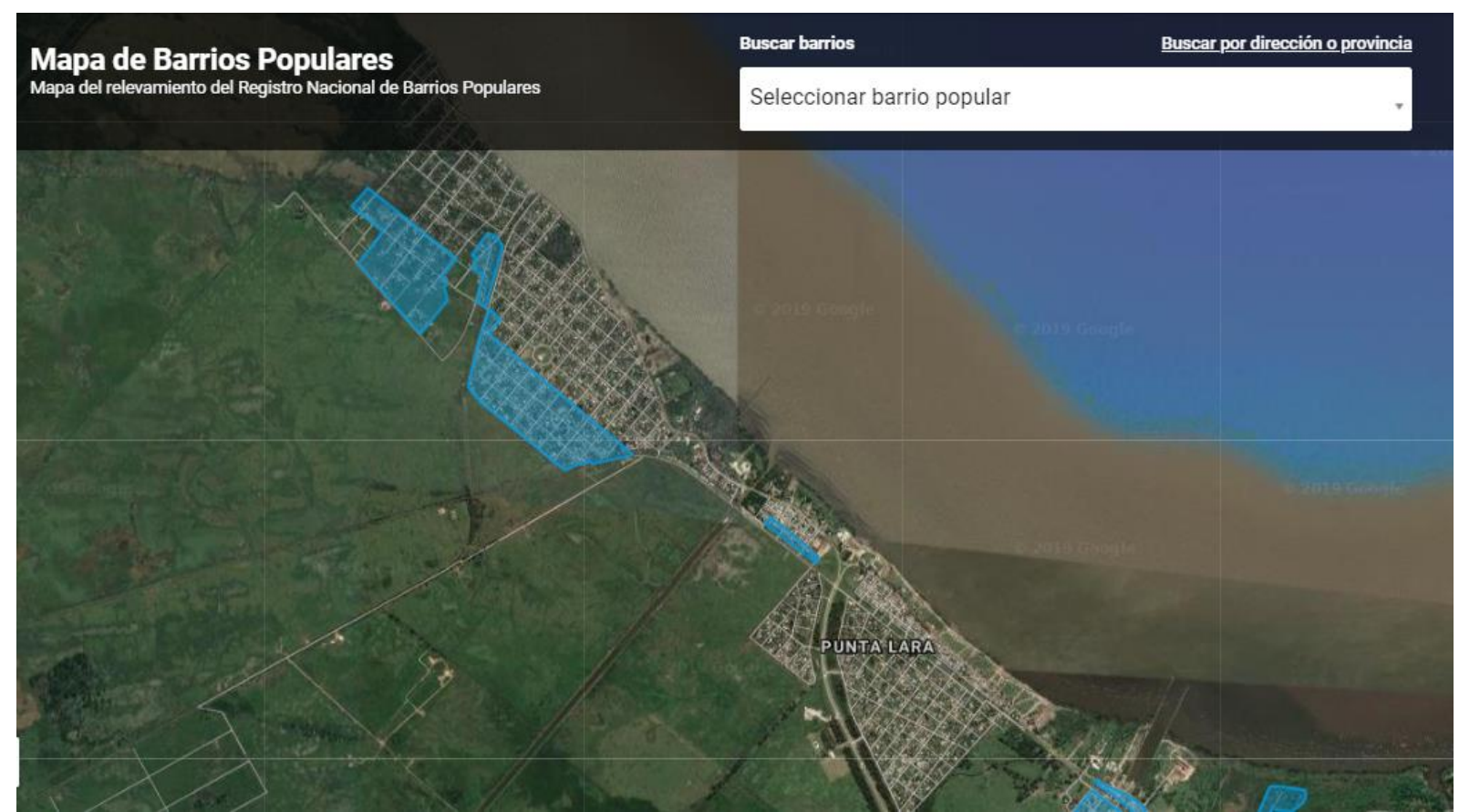

Figura 17. Mapa de Barrios Populares 14 (identificados por los polígonos celestes. Recorte del área de estudio. Fuente: https://www.argentina.gob.ar/barriospopulares/mapa. 2019

\footnotetext{
${ }^{14}$ Según el Registro Nacional de Barrios Populares, se considera "Barrio Popular" a los barrios vulnerables en los que viven al menos 8 familias agrupadas o contiguas, donde más de la mitad de la población no cuenta con título de propiedad del suelo ni acceso regular a dos, o más, de los servicios básicos (red de agua corriente, red de energía eléctrica con medidor domiciliario y/o red cloacal).
} 
De igual modo, el sector de Villa del Plata tuvo un completamiento progresivo de las áreas vacantes, con viviendas destinadas a residencia permanente. El barrio en el que se evidenciaron mayores cambios fue el barrio el Zanjón Piria, con un desarrollo en este último período que permitió una gran ocupación de lotes vacantes con nuevos trazados de calles.

Asimismo, se produjo una transformación de la zona costera producto de una serie de intervenciones que fueron llevadas a cabo con el objetivo de restituir a la población el acceso a la playa, mejorar los equipamientos existentes y las instalaciones a cargo de los diferentes sindicatos que se encuentran en el sector.

En síntesis, en los sucesivos cortes temporales analizados, los indicadores de ocupación muestran que el territorio ha sufrido un proceso desordenado de urbanización (Mapa 1). Este proceso ha respondido no sólo a los factores naturales y climáticos a los que se ve sometida la región, sino también a factores históricos y políticos - modificaciones de gobiernos, iniciativas y políticas, contextos históricos cambiantes. También han tenido influencia cuestiones antrópicas como son las limitaciones en relación a iniciativas para desarrollar estrategias integrales que permitieran el aprovechamiento del recurso costero, la invasión del dominio del agua sin tomar las precauciones necesarias y la ocupación de áreas riesgosas y vulnerables por la marginalidad de las tierras. 

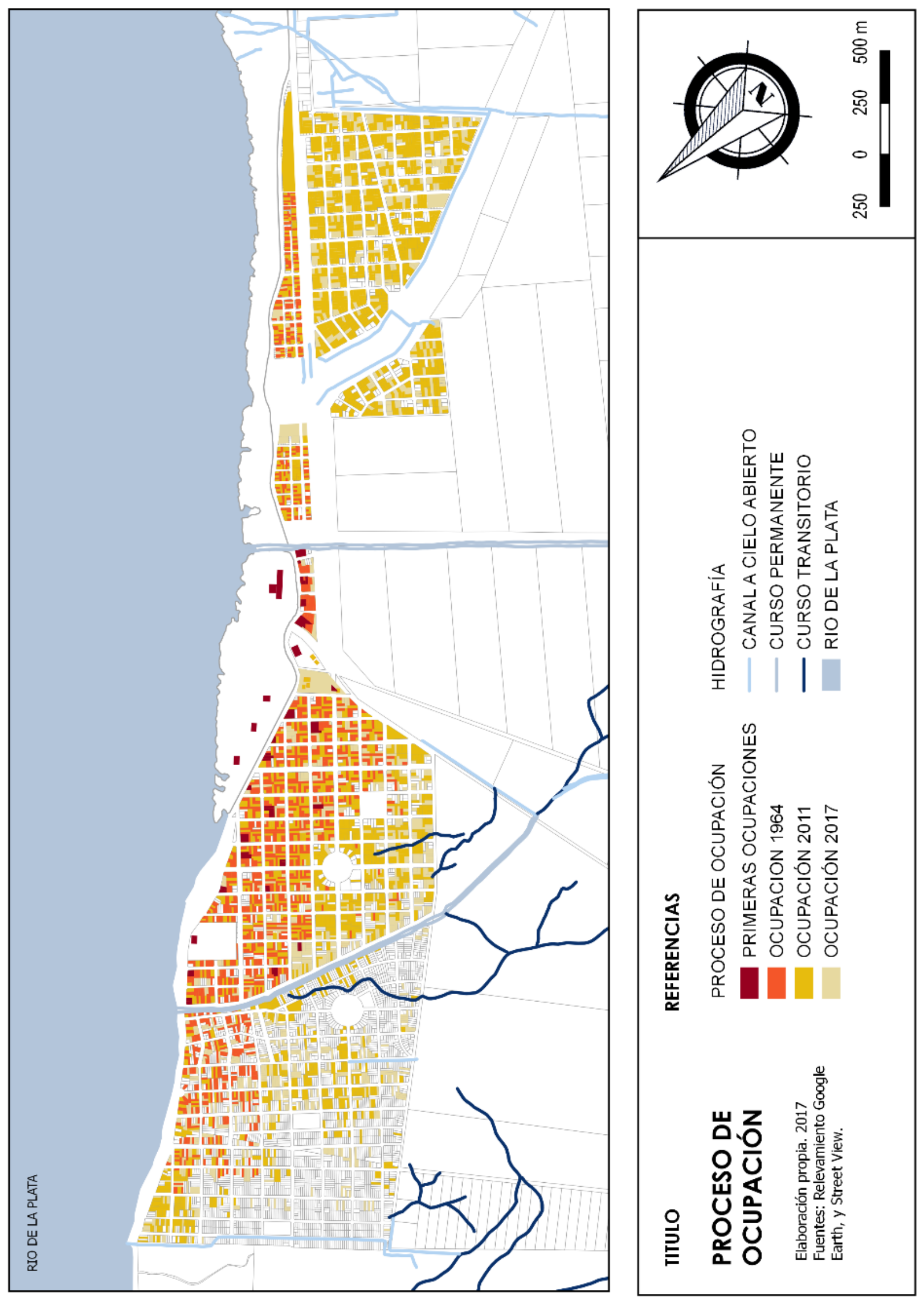

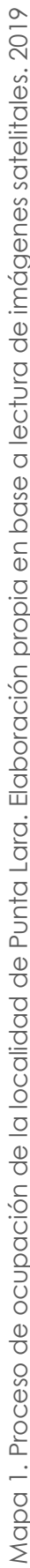


En relación a la ocupación actual de la localidad, puede observarse que la distribución de los usos del suelo en la localidad de Punta Lara está muchas veces condicionada por la presencia de factores estructurantes. El Río de La Plata fomenta la aparición de usos relacionados con la actividad turística, recreativa y deportiva, motivo por el cual, en las zonas próximas a la costa, se localizan campings, clubes y balnearios, además de comercios aislados que apoyan las actividades recreativas. La base de éste atractivo se constituye por la presencia del frente costero y la playa, principalmente en épocas de verano. La oferta de actividades abarca desde zonas verdes sobre ciertas vías principales que se ocupan durante los fines de semana, hasta equipamientos de carácter deportivo-recreativo, la presencia de campings y actividades libres y gratuitas, fomentando el uso costero.

Los usos residenciales se distribuyen dentro del polígono determinado por una serie de barreras urbanas que existen en la localidad (las vías en desuso del ferrocarril, el Río de La Plata y la Selva Marginal). Se reconoce además una zona central que reúne las actividades públicas-administrativas (Municipalidad) de seguridad, de culto y de educación.

A los efectos de la presente investigación se adopta como recorte el área constituida por la subcentralidad, el borde costero y los usos residenciales de influencia directa, específicamente el área comprendida entre la Reserva Natural de Punta Lara y el arroyo sin nombre, incluyendo así los barrios: B Punta Lara (casco), $\mathrm{B}^{\circ}$ Casco Punta Lara, $\mathrm{B}^{\circ}$ Rotonda del Diagonal, $\mathrm{B}^{\circ}$ Villa del Plata y $\mathrm{B}^{\circ}$ Esperanza (Figura 18), un sector que conforma una subcentralidad del Partido de Ensenada y que presenta situaciones y dinámicas diferentes, permitiendo realizar un análisis de una multiplicidad de aspectos relacionados al estudio del derecho a la ciudad.

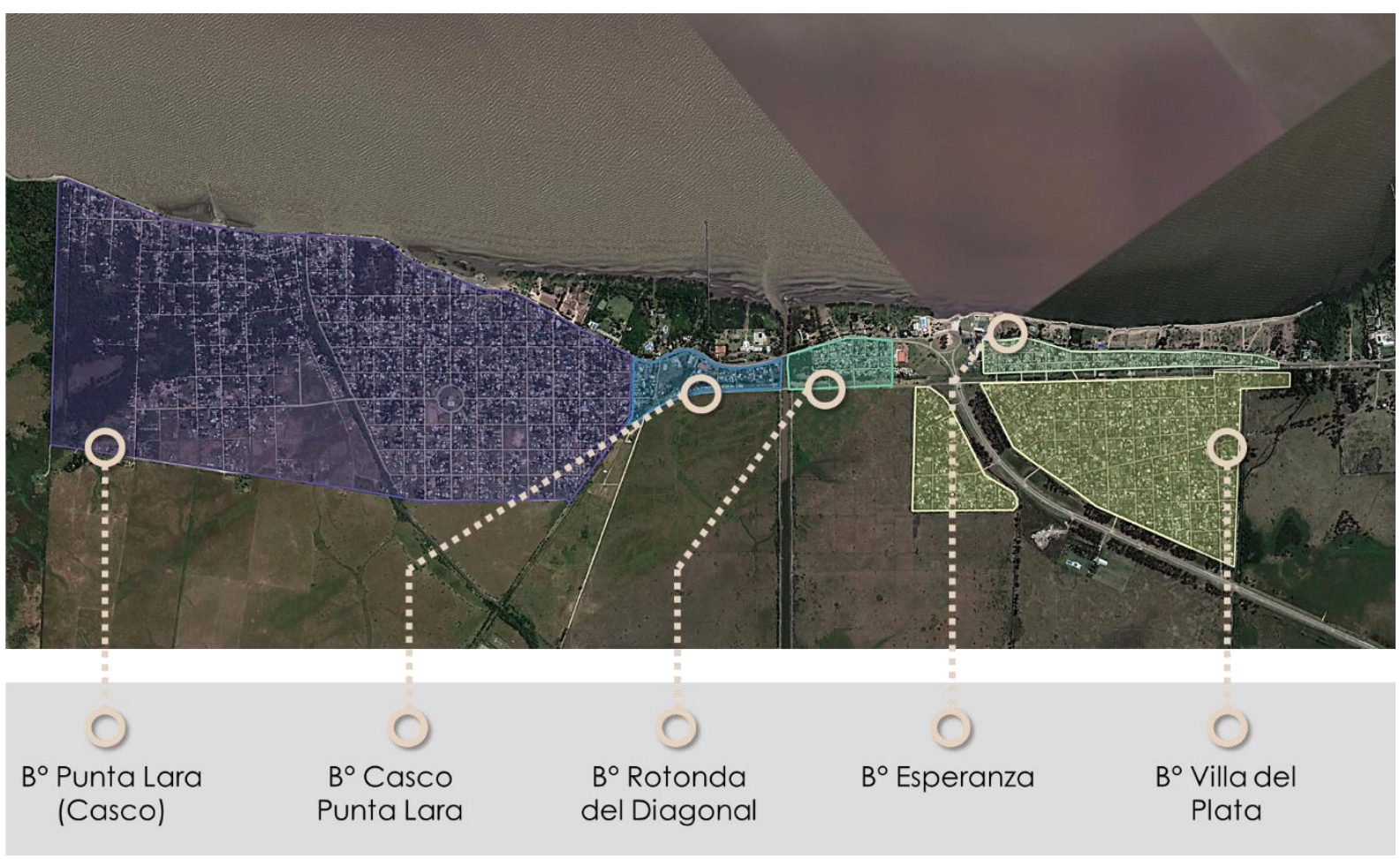

Figura 18. Recorte del Área de Estudio. Elaboración propia. 2019 


\section{2 | Ensayo y aplicación de la variable ciudad incluyente}

Luego de este reconocimiento de las distintas escalas de abordaje del análisis, el ensayo metodológico se realizó a partir de la aplicación de una de las variables, la variable "Ciudad Incluyente".

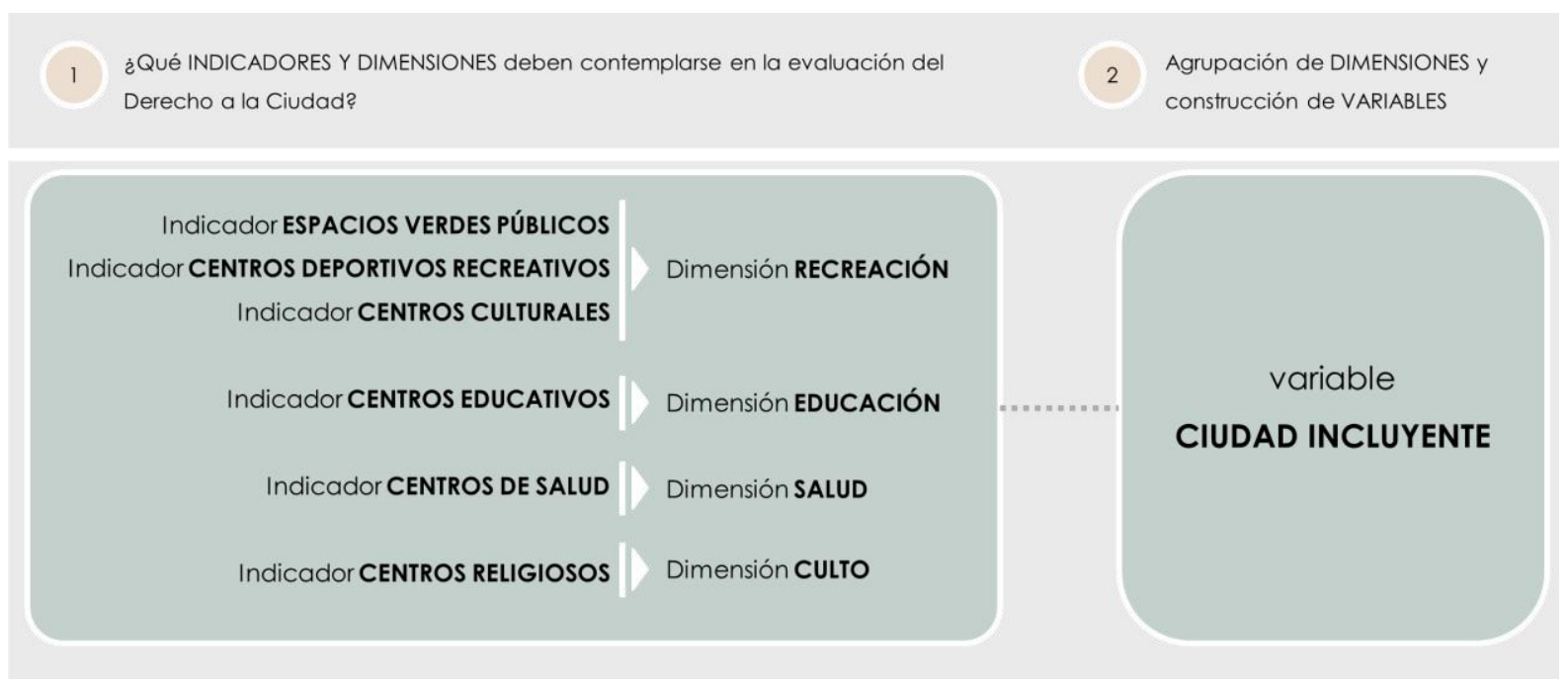

Figura 19. Esquema síntesis variable Ciudad Incluyente. Dimensiones e Indicadores. Elaboración propia. 2019

En esta línea, se partió de uno de los principios del derecho a la ciudad que es el del usufructo equitativo de las ciudades, entendiendo que estas últimas deben ofrecer las condiciones para que todos los habitantes puedan hacer uso de los recursos que se ofrecen en los contextos urbanos, generando espacios que favorezcan el encuentro, el intercambio y la expresión de los ciudadanos.

Este principio se tradujo en la variable "Ciudad Incluyente" cuyo objetivo es generar una ciudad para todos, que pueda fortalecer la convivencia social, la generación y mejoramiento de los espacios públicos y, de igual modo, fortalecer la función cultural, lúdica y recreativa del espacio público; así como el acceso a servicios básicos como son la educación y la salud como par inseparable.

\subsection{1 | Consideraciones metodológicas-conceptuales}

Debido a que la metodología se basó, como fuera indicado en los apartados anteriores, en un análisis cuantitativo a partir de indicadores que se interpelaron e interrogaron mediante técnicas cualitativas, presentaremos ciertas consideraciones metodológicas-conceptuales para el desarrollo del análisis.

\subsubsection{Del análisis cuantitativo}

En primera instancia, desarrollaremos brevemente los conceptos principales del análisis espacial (Figura 20), utilizados por la geografía cuantitativa -y que los Sistemas de Información Geográfica han permitido hacer operativos bajo un mismo ambiente de trabajo- aplicados a la presente investigación: localización espacial; distribución social; asociación espacial; interacción espacial y evolución espacial.

El primero de ellos -localización espacial- "considera que todas las entidades (con sus atributos asociados) tienen una ubicación específica en el espacio geográfico" (Buzai, 2010). Esto quiere decir que, en principio, todas las entidades se encuentran referenciadas en relación a un sistema de coordenadas geográficas (latitud-longitud). Sin embargo, también puede hablarse de que las entidades poseen una posición específica y cambiante respecto de otros sitios con los cuales establece vínculos de carácter funcional; es decir, que a pesar que una entidad posea siempre un sitio definido por coordenadas, las 
posiciones en el espacio relativo varían y se achican las distancias constantemente a partir de los avances que se producen, principalmente, en materia de transporte y comunicaciones (proceso de globalización).

El concepto de distribución espacial "considera que el conjunto de entidades de un mismo tipo se reparten de una determinada manera sobre el espacio geográfico" (Buzai, 2010). Estas formas pueden ser puntos, líneas o polígonos (áreas) con diferentes atributos asociados en sistema vectorial, o localizaciones dispersas que representan puntos y zonas con clases similares contiguas en sistema ráster.

El de asociación espacial es otro de los conceptos relevantes en el análisis espacial, que "considera el estudio de las semejanzas encontradas al comparar distintas distribuciones espaciales" (Buzai, 2010); comparaciones que pueden hacerse a partir del análisis visual de la superposición de diferentes cartografías temáticas, verificando correspondencias, superposiciones e intersecciones; y generando áreas homogéneas con diferentes características combinadas. Así, "ese trazado de límites sobre un mapa, como resultado de la combinación de las distribuciones y asociaciones espaciales se transforma en una herramienta importante de planificación" (Buzai, 2010).

Además, el concepto de interacción espacial "considera la estructuración de un espacio relacional en el cual las localizaciones (sitios), distancias (ideales o reales) y vínculos (flujos), resultan fundamentales en la definición de espacios funcionales" (Buzai, 2010).

Finalmente, el concepto de evolución espacial "considera la incorporación de la dimensión temporal a través de la permanente transición de un estado a otro" (Buzai, 2010). Resulta importante ya que, a pesar de que los estudios geográficos se abordan fundamentalmente en el presente, no se deja de reconocer la importancia de la dimensión temporal para un análisis de mayor integralidad, incorporando las situaciones pasadas que dan origen a las manifestaciones empíricas del presente.

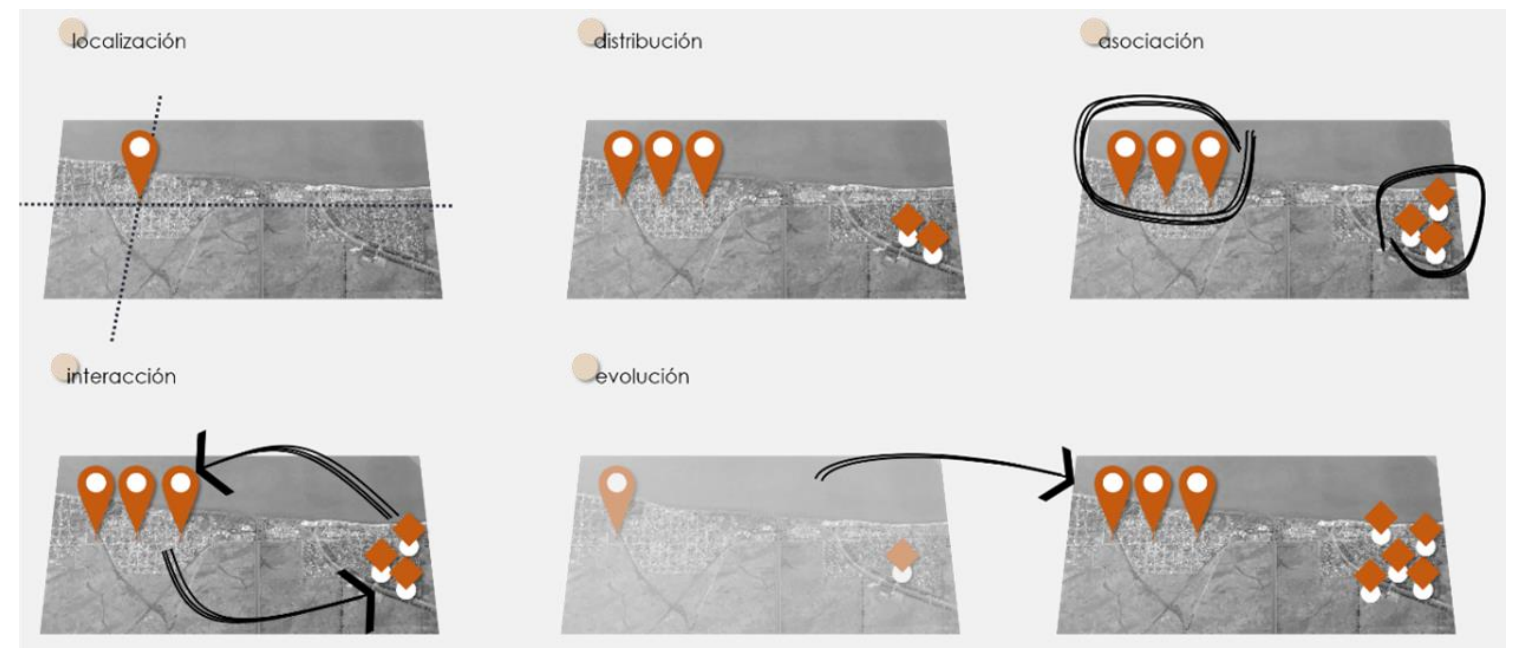

Figura 20. Conceptos principales Geografía Cuantitativa. Elaboración propia en base a "Análisis Espacial con Sistemas de Información Geográfica: sus cinco conceptos fundamentales" BUZAI, Gustavo (2010).

Con el objeto de aportar a la construcción de una herramienta para analizar el grado de concreción de este derecho, se avanzó en el desarrollo de indicadores cuantitativos que dieran cuenta de esta situación, que se complementaron con la aplicación de técnicas de análisis cualitativas que permitieron interpelar los resultados obtenidos. Los datos y el producto de estos estudios se expresaron en un Sistema de Información Geográfica (SIG), entendido como una "base de datos georreferenciada, diseñada para visualizar, editar, gestionar y analizar información geográfica con el fin de contribuir a resolver problemas complejos de planificación y gestión del territorio" (Dirección Provincial de Ordenamiento Urbano y Territorial, 2011), que permitió estudiar los indicadores, georreferenciarlos, espacializarlos y establecer relaciones entre cada uno de ellos.

La construcción y definición de las variables e indicadores se enfocaron en aquellos aspectos que pueden ser evaluados de alguna forma en el territorio (expresión territorial), debido a que es en este punto en que, 
como arquitecta con formación en urbanismo, pueden hacerse los mayores aportes con base en la pertinencia y experticia de la profesión. Cabe destacar que, pese a que la integralidad y complejidad que implica el derecho a la ciudad requiere, necesariamente, de un equipo interdisciplinario, el estudio que se presenta a continuación se enfocó en la doble articulación de un análisis a partir de técnicas cuantitativas, interpelado a partir del uso de técnicas cualitativas. Así, el análisis de las dimensiones desde esta doble articulación determina la potencialidad de transformación de cada uno de estos aspectos, en pos de acercarse cada vez más al cumplimiento del derecho a la ciudad.

Otra de las consideraciones metodológicas a realizar se relaciona con el análisis de los radios de cobertura de los servicios y espacios que se utilizan en la aplicación de la metodología al caso. En este punto, nos apoyaremos en la concepción de "caminabilidad" de Jane Jacobs (2011), quien recalcaba la importancia de caminar las ciudades para comprenderlas y entenderlas, así como la idea de las calles como espacios fundamentales para la convivencia y la interacción social. Más aún, Jeff Speck (2013), explica que una parte importante de la "Teoría de la Caminabilidad" requiere que las ciudades promuevan calles que cumplan con cuatro condiciones esenciales: que sean seguras, confortables, interesantes y útiles; entendiendo que ser "útiles" implica que la población pueda tener acceso a los espacios de uso cotidiano en distancias relativamente cercanas y que puedan acceder a ellos sin necesidad de recurrir a transportes privados.

Así, las ciudades caminables resultan más eficientes, entre otras cuestiones, en términos económicos (reducción de tiempos de transporte, derivan en reducción de costos, población con mejor calidad de vida y, por ende, aumento en los ingresos económicos tanto individuales como de la comunidad en su totalidad); de salud (ciudades caminables favorecen el desarrollo de actividades recreativas, deportivas, que derivan en mejores condiciones de salud para los habitantes); y de sostenibilidad; mejorando la calidad de vida de los ciudadanos que las habitan. Por este motivo, en el marco de esta variable nos apoyamos en este concepto para definir las distancias óptimas de los indicadores estudiados, así como parámetros internacionales de cobertura ${ }^{15}$. Con esto presente, se trata de conseguir que la población pueda disponer, en un radio de proximidad adecuado -que no implique la necesidad de recurrir a diversos medios de transporte-, del mayor número de equipamientos, de manera que pueda cubrir diversidad de necesidades culturales, recreativas, educativas y sanitarias.

Conjuntamente, la investigación requería, en principio, determinar la cantidad de población que habita en la localidad debido a que las variables a analizar necesitaban de este valor como insumo de referencia, entendiendo al ciudadano como componente central de la investigación y constituyendo un parámetro fundamental para el estudio del derecho a la ciudad.

En relación a esto, la información procedente del Censo Nacional de Población, Hogares y Viviendas del año 2010 daba cuenta de una situación relativamente homogénea en toda la localidad (Mapa 2), sin grandes variaciones, con radios censales que presentaban entre 300 y 900 habitantes. Esto se debe a que la metodología que se utiliza para el desarrollo del Censo, toma como unidad de análisis territorial al radio censal, disminuyendo el reconocimiento de la distribución real de la población en el territorio.

\footnotetext{
15 En relación a estas recomendaciones, el presente trabajo se apoya en el "Sistema de indicadores y condicionantes para ciudades grandes y medianas", desarrollado por el MAGRAMA, Agencia de Ecología Urbana de Barcelona y La Red de Redes de Desarrollo Local Sostenible (2010). Por este motivo, se realiza la aclaración en este apartado de consideraciones metodológicas, sin reiterar esta referencia en cada uno de los indicadores analizados, en pos de evitar reiteraciones.
} 

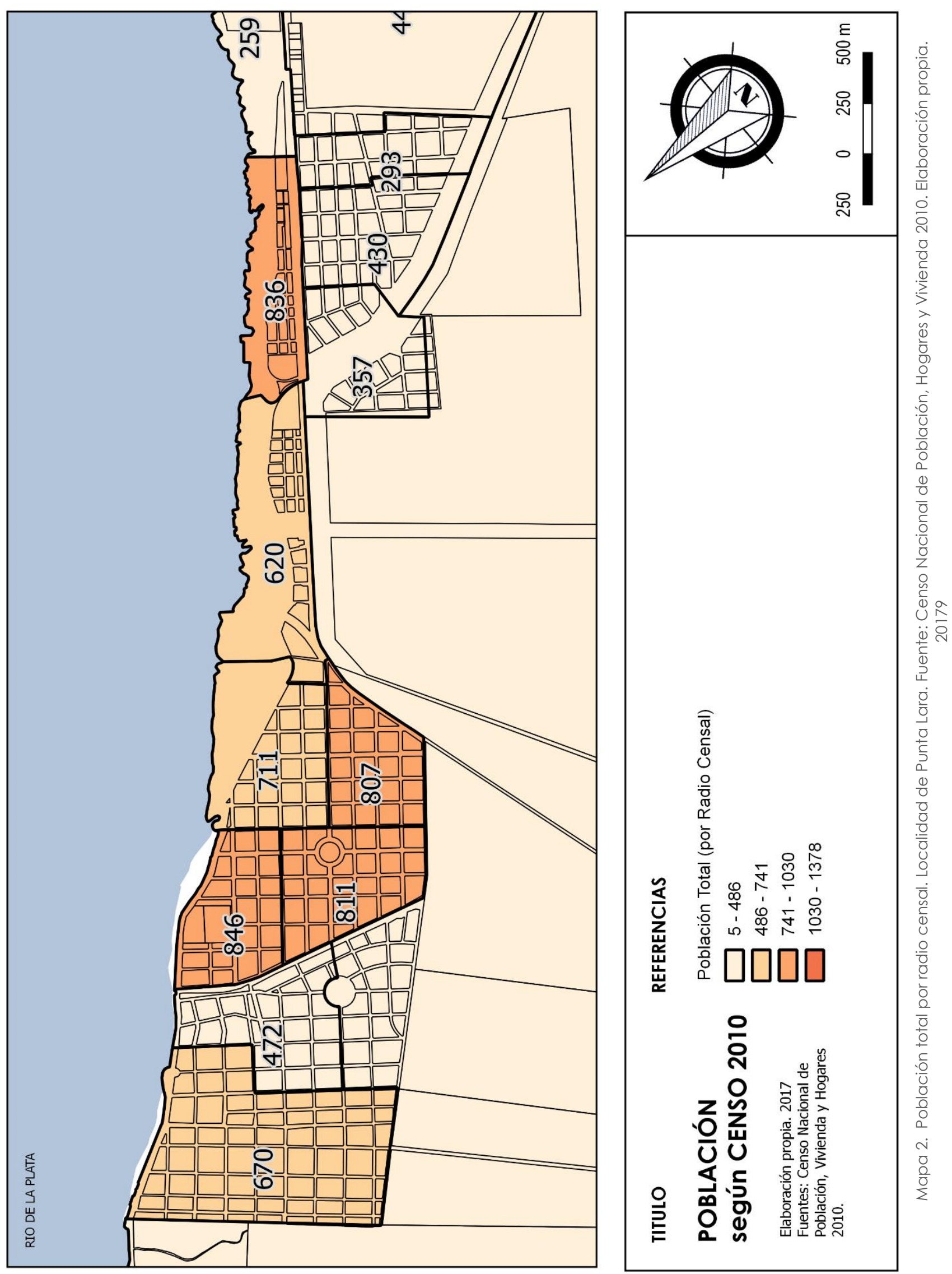
Así, puede observarse que el barrio Punta Lara Casco presenta las mayores variaciones, compuesto por radios censales que se componen de entre 472 y 846 habitantes y el barrio Villa del Plata es el más homogéneo, con variaciones de población entre 293 y 430 habitantes. El barrio Casco Punta Lara y el barrio Rotonda del Diagonal se unifican a partir de radios censales que no responden a los límites de cada uno de ellos, con una población de aproximadamente 620 habitantes. El barrio Esperanza también se encuentra seccionado por dos radios censales diferentes, concentrando una mayor cantidad de población -estimada en 836 habitantes-.

Debido a que en este caso era necesario desagregar la información para realizar estudios más profundos de los indicadores, se buscó disminuir esa unidad de análisis a nivel de manzanas como unidades territoriales. De esta forma, los valores fueron estimados mediante un proceso de observación de parcelas ocupadas y vacantes, al año 2017 (a fin de obtener una mayor precisión, debido a que la información del Censo corresponde al año 2010) y la definición una cantidad de habitantes por cada una de ellas. De esta manera, a través de la fotointerpretación de imágenes satelitales de la localidad -utilizando programas como el Google Earth y sistemas abiertos como el OpenStreet Map- se procedió a determinar, inicialmente, parcelas ocupadas y parcelas vacantes.

Con esa información se construyó el siguiente mapa (Mapa 3), que demuestra -acorde al proceso de ocupación que fuera analizado en el apartado anterior- que la mayor cantidad de parcelas ocupadas se encuentran en la zona costera, disminuyendo la ocupación hacia la zona Suroeste principalmente, en cercanías de la Reserva Natural de Punta Lara. En estas zonas se empieza a observar la presencia de ocupaciones aisladas, viviendas unifamiliares de pequeña escala que empiezan a asentarse en "islas" del territorio generando una dispersión. En contraposición, el sector de Villa del Plata, pese a encontrarse más alejado del borde costero, en la zona Sudeste, presenta un proceso de ocupación pleno, en parcelas de mayor tamaño. 

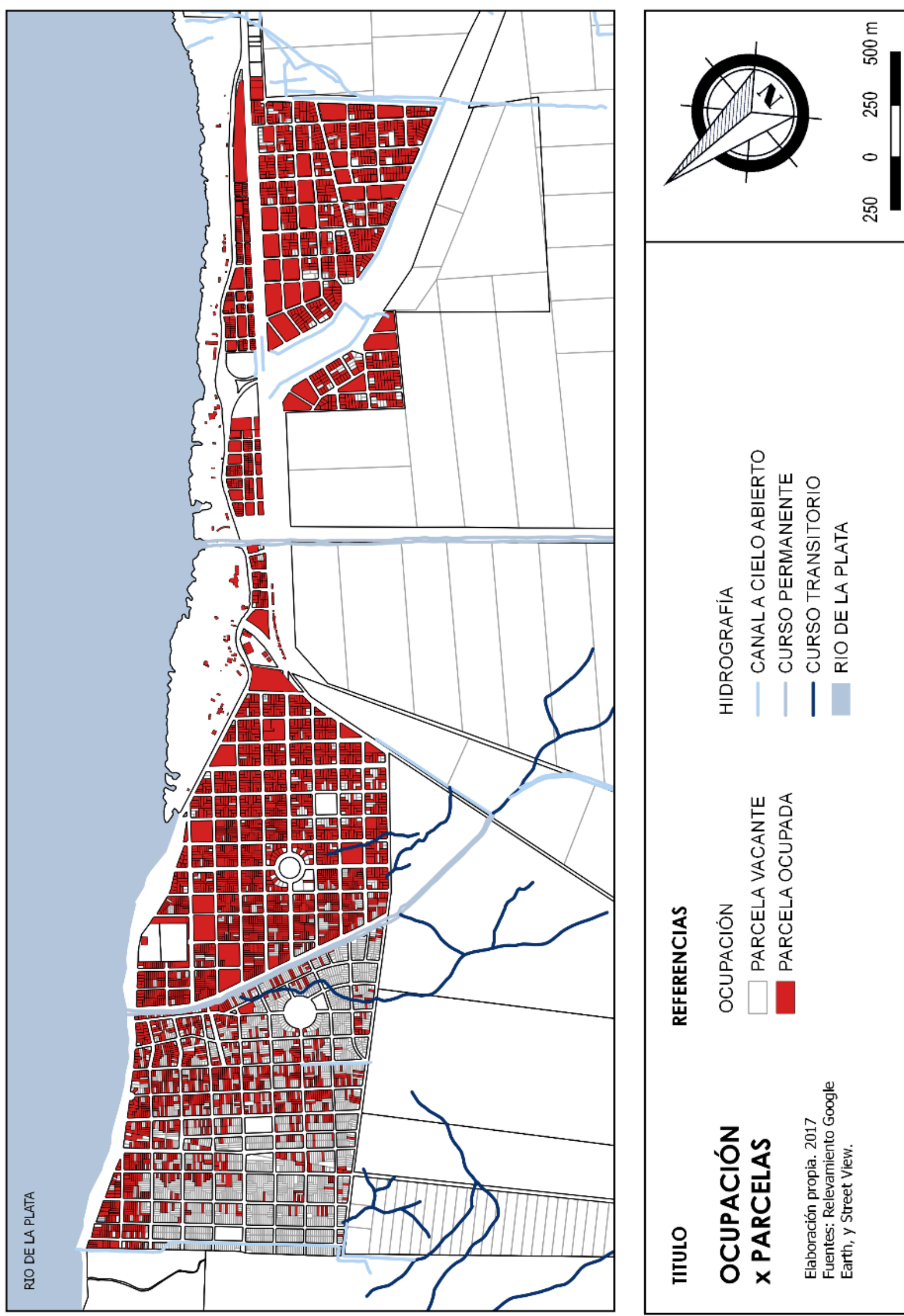

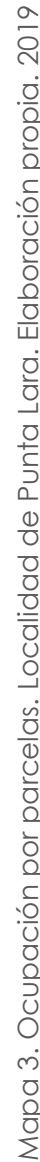

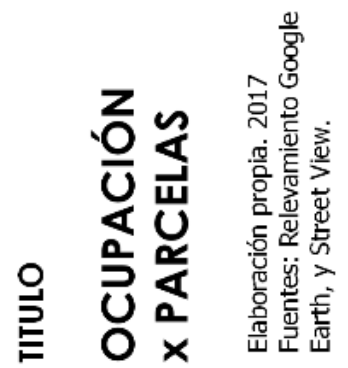


A continuación, resultaba necesario superar el mero hecho de definir si las parcelas se encontraban vacantes u ocupadas. Para eso, se adoptó, en relación a los valores promedios de ocupación de la localidad, un promedio de 2,5 habitantes por parcela ocupada. La fórmula utilizada para el cálculo de este indicador fue:

OCUP. = Parc.Oc. $\times 2,5$ hab.

(x manz.) (x manz.) (x parcela)

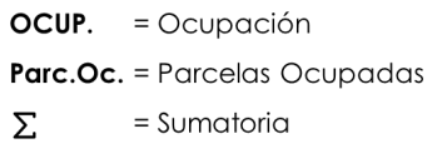

\section{OCUP. TOTAL $=\sum$ OCUP.}

(x manz.)

Así, se determinó un estimativo de cantidad de habitantes por parcela, en base a las características de la localidad, obteniendo como ocupación un total de 11.406 habitantes. Estos datos y consideraciones constituyen el punto de partida para el análisis cuantitativo que se desarrollará.

\subsubsection{Del análisis cualitativo}

A fin de dar respuesta a los aspectos cualitativos del análisis y reconocer la visión de la población en relación a la variable Ciudad Incluyente, se desarrollaron encuestas a habitantes de la localidad, apoyados en el hecho de que este tipo de técnica "permite recolectar datos sobre actitudes, creencias y opiniones de los individuos estudiados e indagar sobre múltiples temas (...) se caracteriza por su adecuación para relevar muchas propiedades referidas a muchos individuos" (Marradi, Archenti y Piovani, 2007); lo que permitió complementar y enriquecer la aplicación de la variable seleccionada a partir de una pluralidad de voces.

Para el cálculo del tamaño de una muestra representativa, adecuada y válida se tomó como universo a investigar los 11406 habitantes calculados en el análisis de la ocupación y se aplicó la siguiente fórmula ${ }^{16}$ :

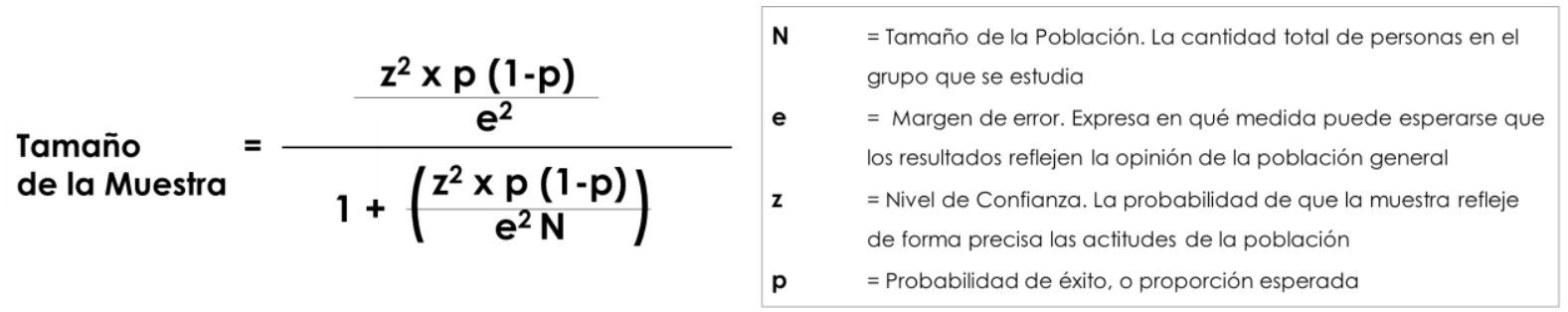

A partir de esta fórmula, se definió para un tamaño de población de 11406 habitantes, con un nivel de confianza de $85 \%$ y un margen de error de $12 \%$, una muestra consistente en $36 / 37$ encuestas.

En términos operativos, se desarrolló una encuesta con participación del encuestador, basada en el método coincidental (de abordaje en la vía pública), debido a que esto permitía aclarar dudas a los encuestados, ampliar su explicación sobre las temáticas indagadas, realizar cuestionarios más largos, entre otras cuestiones; al mismo tiempo que hacía posible acceder a las representaciones de los habitantes.

\footnotetext{
${ }^{16}$ Hernández Sampieri, R.; Fernández Collado, C; Baptista Lucio, P. (2010). Metodología de la investigación (5ta Edición). México. Editorial McGRAW-HILL / INTERAMERICANA
} 
En esta línea, se propuso un cuestionario semiestructurado, cuya característica principal es que permite "presentar a todos los encuestados los mismos menús de respuestas (...), se orienta a asegurar, en alguna medida, la comparabilidad de éstas, ya que los estímulos han sido los mismos para todos los integrantes de la muestra" (Marradi, Archenti y Piovani, 2007), incorporando de esta forma, preguntas abiertas. Además, se complementó este desarrollo con la técnica de la observación, definida como aquella que permite "establecer algún tipo de contacto empírico con los datos/sujetos/situaciones de interés a los fines de su descripción, explicación, comprensión, de tipo directa, en la que "el investigador se pone en contacto directo con el fenómeno de interés" (Marradi, Archenti y Piovani, 2007) y no controlada, es decir, que "se observa la situación en su ambiente natural, sin alterar el contexto ni recrearlo artificialmente" (Marradi, Archenti y Piovani, 2007). Así, para la organización de las encuestas y el levantamiento de datos, se seleccionaron una serie de puntos relevantes de la localidad, en los que se concentra normalmente cierta cantidad de población, que permitiera indagar a la mayor cantidad y variedad de encuestados posible.

El cuestionario se construyó a partir de la definición de interrogantes referidos a cada uno de los indicadores construidos para la Variable Ciudad Incluyente, con el objeto de determinar el uso que la población hace de cada uno de los espacios/centros, con qué frecuencia los utiliza o por qué motivo no los utiliza y, asociado a este último punto, qué aspectos podrían mejorarse, a fin de inferir si la población encuentra una satisfacción de los derechos incluidos como parte del análisis de la variable ciudad incluyente o considera que deben proponerse mejoras para poder satisfacer estas necesidades (Ver Anexo I - Cuestionario). En este punto, algunos de los interrogantes solicitaban a la población realizar una contrastación seleccionando la respuesta más cercana a su percepción, a partir de una escala definida en tres valores: Bueno, Regular y Malo; que permitiera luego cotejar y evaluar los indicadores comparativamente ${ }^{17}$.

La encuesta se inició con una serie de datos demográficos, a fin de observar rangos de edad que hacen uso de los diferentes espacios/centros y, fundamentalmente, su lugar de residencia; que orientan a la comprensión de las subjetividades y sentires de los habitantes de la localidad.

El perfil general de los encuestados se caracterizó por la variedad, permitiendo una generalización sobre la localidad de Punta Lara. En relación a esto, pudo observarse rangos de edad diferentes ya que, de la totalidad de los encuestados, el 19\% se encontraba entre los 18 y los 30 años, el $54 \%$ entre los 30 y 42 años, el 16\% entre los 42 y los 54 , y el 11\% restante entre los 54 y 66 años de edad, reflejando la variedad en las edades del subconjunto (Figura 21).
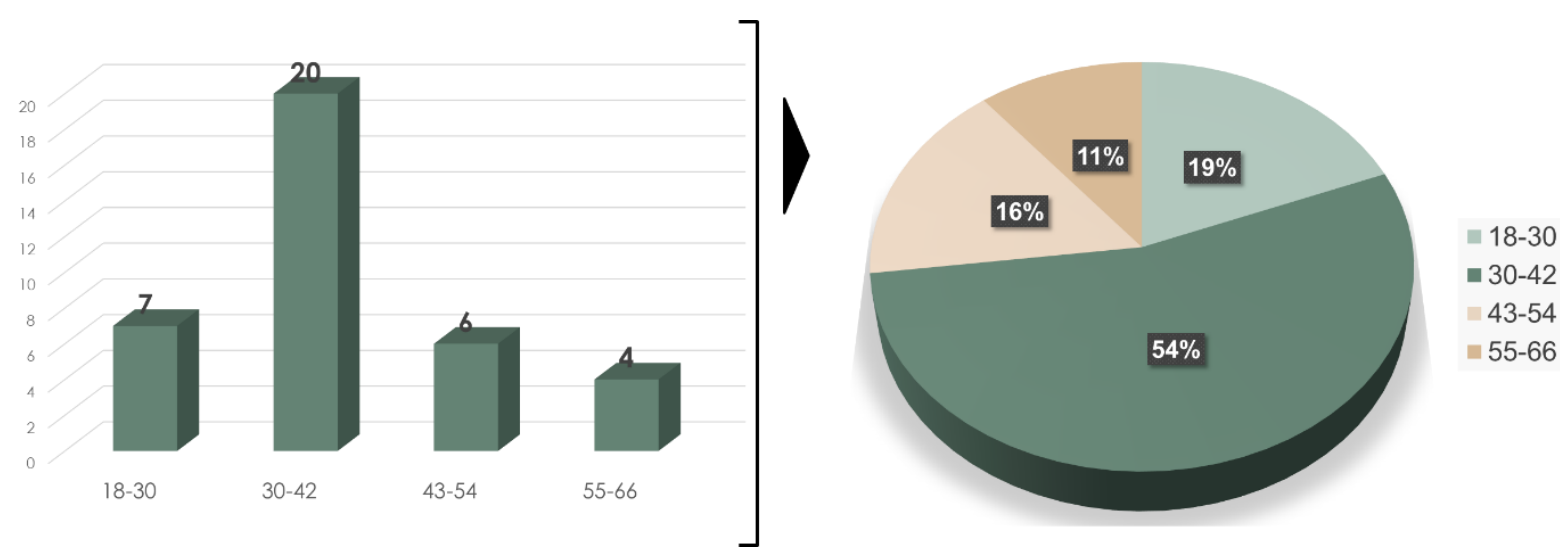

Figura 21. Edad de los encuestados. Elaboración propia. 2019

\footnotetext{
${ }^{17}$ Complementariamente, se desarrollaron consultas informales de opinión a población que no reside en el área de estudio, pero poseen comercios o desarrollan otro tipo de actividades laborales (por ejemplo, la oferta de bienes y servicios) constituyendo, por tanto, actores también relevantes para el análisis.
} 
En relación al lugar de residencia de los habitantes encuestados, pudo observarse que un estimado por encima de la media contaba con una trayectoria de residencia significativa, con más de 10 años viviendo en la localidad y que, en ocasiones, se describió como "de toda la vida". Con lo cual, puede interpretarse que estos encuestados no sólo poseen conocimiento sobre la localidad y el área de estudio, sino que también hay un arraigo importante con Punta Lara (Figura 22).

Cabe destacar, en relación a esta pregunta en concreto que, pese a tratarse de días de semana en época de verano (en coincidencia con la estacionalidad de la actividad turística en la localidad), hubo población que al ser consultada acerca de su lugar de residencia, manifestó no residir en la localidad de Punta Lara, sino ser de otras localidades del partido, e incluso por fuera del partido de Ensenada. Por este motivo, no fueron consultados formalmente acerca del contenido de las encuestas -debido a que, como fuera indicado, las mismas apuntaban a indagar la visión de la población residente en la localidad-; pero manifestaron también hacer un uso regular de los espacios y las actividades gratuitas que se desarrollan en la localidad. Esta situación, refuerza la idea de Punta Lara como un destino turístico y, por ende, con características particulares que pueden observarse, entre otras cuestiones, en la concentración de actividades, eventos y espacios sobre el borde costero.
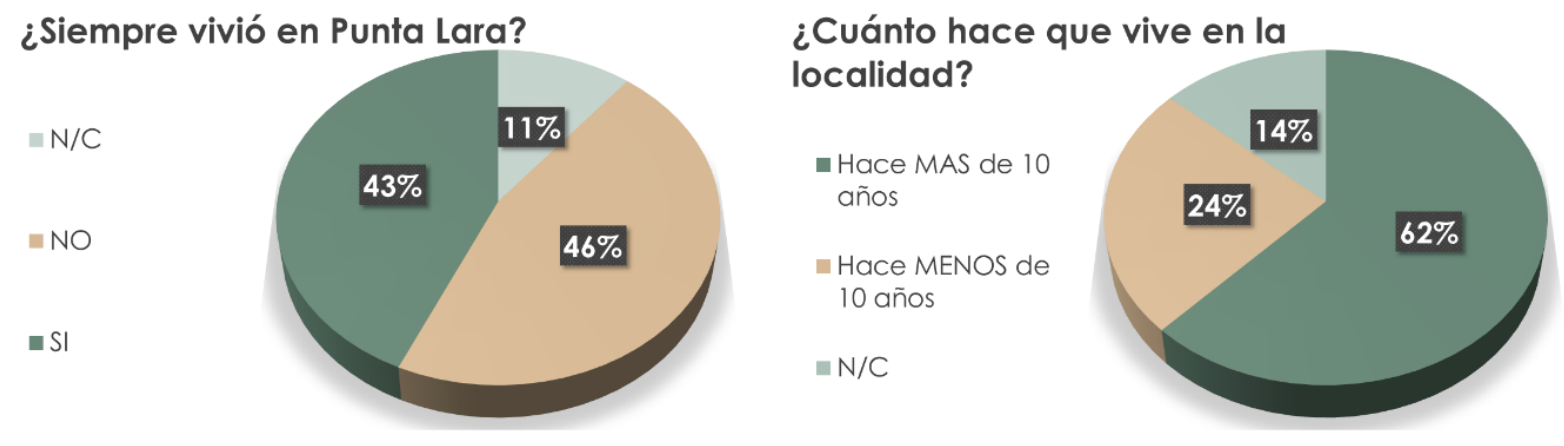

Figura 22. Resultados encuestas: datos básicos de residencia de población. Elaboración propia, 2019

En términos de la territorialización de las encuestas realizadas, es decir, la ubicación geográfica de aquellos sectores indicados como lugares de residencia, se identificaron encuestados procedentes de los diferentes barrios que conforman al área de estudio, lo que permite acercarse a una variedad importante de apreciaciones y percepciones de los habitantes de la localidad (Mapa 4). 

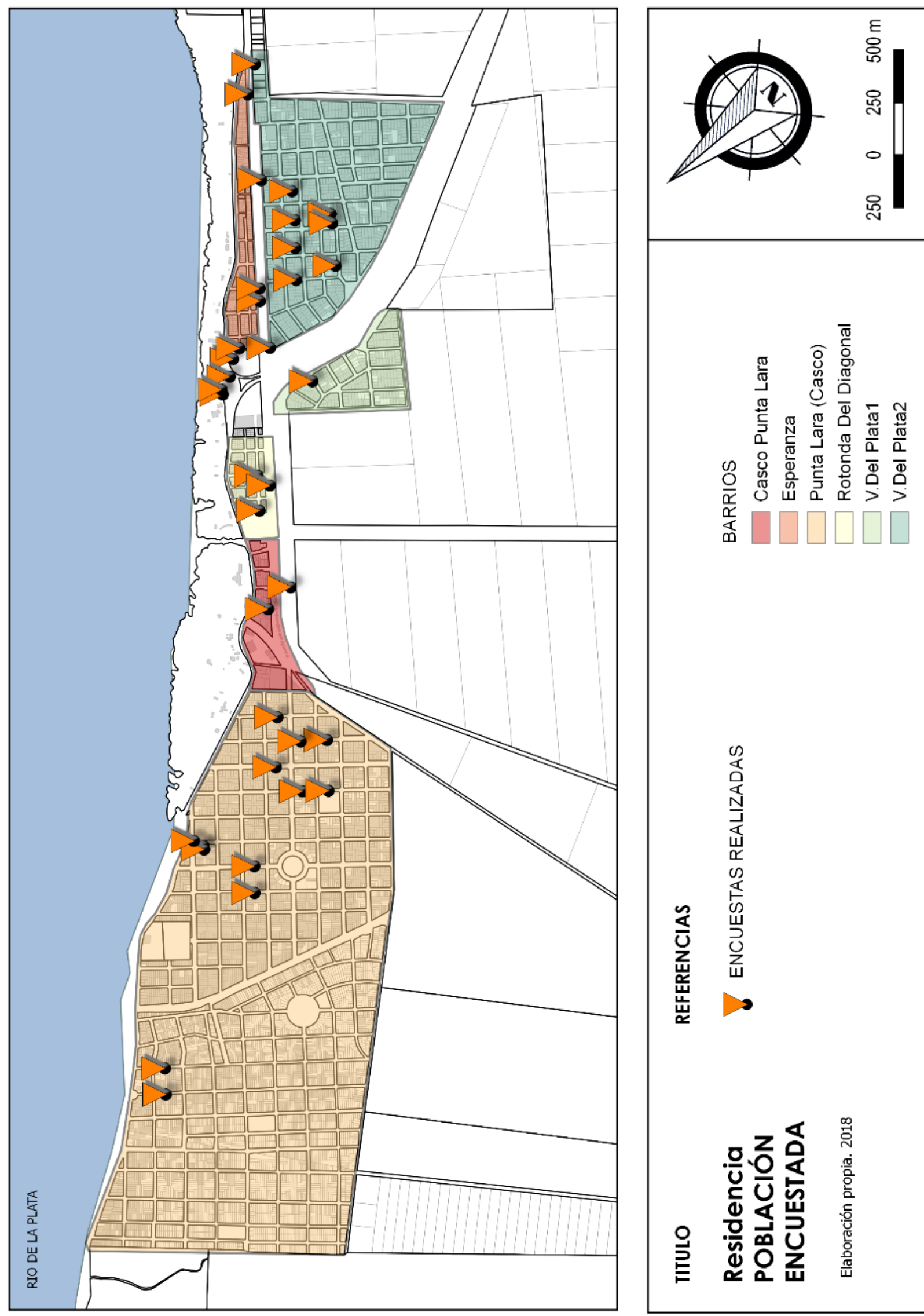


\subsection{2 | Dimensión RECREACIÓN}

Con estos datos presentes, la primera dimensión analizada fue la de "RECREACIÓN", contemplando los indicadores de "Espacios Verdes/Públicos", "Centros Deportivos Recreativos" y el indicador de "Centros Culturales".

\subsubsection{Indicador de ESPACIOS VERDES/PÚBLICOS}

El espacio verde/público constituye en la actualidad el espacio para la convivencia social y colectiva que las ciudades deben fomentar, garantizando el bienestar de la población y la interacción, ya sea de las personas entre ellas, como de las personas con un ámbito de calidad, en pos de acercarse a la satisfacción del derecho a la ciudad. Como afirma J.Jacobs (1961), "la existencia de espacios de socialización y encuentro ayudan a la creación de vínculos entre las personas. Es este sentimiento de comunidad, de responsabilidad social, el que hace que la gente se sienta segura". Por este motivo, se trata de un descriptor importante debido a que son los espacios públicos y las áreas verdes las que, por sus características morfológicas y funcionales, fomentan la convivencia y el encuentro de los ciudadanos y, por ende, las ciudades deberían proveerlas, garantizando el libre acceso a estos espacios para todos sin distinciones.

Las preguntas conductoras para el análisis de este indicador fueron varias: ¿Existen suficientes espacios públicos para el sector? ¿Se encuentran estos espacios bien distribuidos? ¿En qué condiciones se encuentran? ¿Son utilizables? ¿La sociedad los reconoce como espacios públicos de uso? ¿Cómo están equipados? ¿Se observa la presencia de vegetación?

En esta línea, el Decreto-Ley 8912/77, define como "espacio verde público" a aquellos "sectores públicos (en los que predomine la vegetación y el paisaje), cuya función principal sea servir a la recreación de la comunidad y contribuir a la depuración del medio ambiente" (Art.8 Decreto-Ley 8912/77). Resultaba importante distinguir el carácter de estos espacios - de acceso público o de acceso restringido-, ya que esto permitía reconocer aquellos equipamientos a los que toda la población tiene acceso, sin importar su condición socioeconómica.

Abundando, la ley define que "Los espacios verdes o libres públicos de un núcleo urbano serán dimensionados en base a la población potencial tope establecida por el Plan de Ordenamiento para el mismo, adoptando un mínimo de diez metros cuadrados $\left(10 \mathrm{~m}^{2}\right)$ de área verde o libre por habitante" (Art.13 Decreto-Ley 8912/77). La Organización Mundial de la Salud también considera a los espacios verdes como fundamentales para el desarrollo de la vida en la ciudad y define como parámetro un valor de 10m2 de superficie verde por habitante, pero aclara también la necesidad de que estos espacios se encuentren distribuidos de manera adecuada.

En términos formales, se suma a esta definición la concepción de "espacios verdes/públicos" como todos aquellos espacios de estancia (plazas, parques, paradores), con una superficie mínima de 1.000 m2 y con más del 50\% del área permeable (sin considerar a las superficies verdes ligadas al tráfico). 


\section{A | Análisis cuantitativo del Indicador}

Inicialmente, tomando entonces como parámetro lo indicado en el decreto-ley, se evaluó la cantidad de espacio verde (en m2) por persona, aplicando la siguiente fórmula:

\section{SverdeT $=\sum$ SverdeP \\ hab.}

Sverdet $\quad=$ Superficie Verde Total (en m2)
$\begin{array}{ll}\sum \text { SverdeP } & =\text { Sumatoria de Superficies de } \\ \text { Espacios Verdes/Públicos identificados (en m2) } & \\ \text { hab. } & =\text { Habitantes }\end{array}$

$=17,86 \mathrm{~m} 2$ por habitantes

\section{406 habitantes}

Con esta información, pudo interpretarse que el porcentaje de espacios verdes (en m2) por habitantes es elevado (17,86 m2/hab), acorde a los parámetros estudiados y las normas del decreto-ley 8912 mencionadas previamente. Sin embargo, contrariamente a lo que estos valores puedan indicar, el acceso real de la población a estos lugares se encuentra limitado. Además, durante la época estival y los fines de semana, este porcentaje también disminuye sensiblemente ante la presencia de población que no reside en el área de estudio, sino que se acerca de regiones y localidades cercanas.

En esta línea, se buscó evaluar la proximidad de la población a estos espacios de diferentes dimensiones y funcionalidades, identificándolos, reconociendo la superficie estimada que ocupan cada uno de ellos se consideraron solo los espacios verdes de acceso público ${ }^{18}$ - (Figura 23) y localizándolos en el territorio (Mapa 5).

NOMBRE
PARADOR MUNICIPAL
PARADOR MUNICIPAL 8,9 y 10
PLAZA MIRADOR "Néstor Kirchner"
PREFECTURA
PARADOR MUNICIPAL 5
PARADOR MUNICIPAL 7
PARADOR MUNICIPAL 4
PARADOR MUNICIPAL 3
PLAZA
RESERVA NATURAL "PUnta Lara"
TOTAL

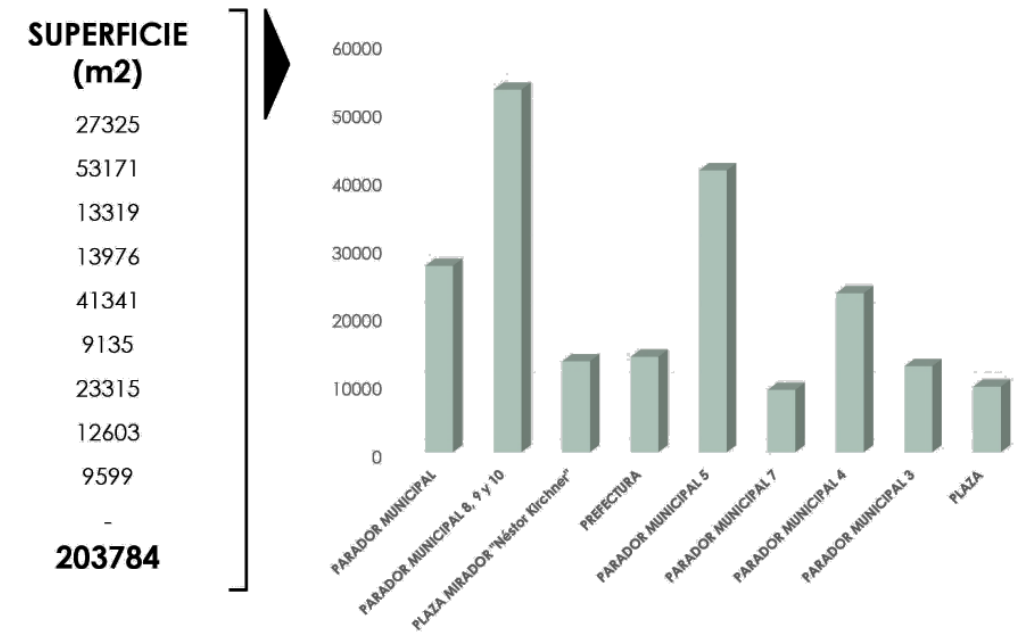

Figura 23. Espacios verdes/públicos. Superficies aproximadas (en m2). Elaboración propia. 2019

Además, existen espacios verdes/públicos que presentan una consolidación precaria o inexistente -por ejemplo, la plaza que aparece identificada en la subdivisión, sobre calles 11 y 120, así como algunos paradores municipales- situación que genera un impacto importante en relación al acceso real de la población al espacio verde; debido a que estos no se encuentran equipados, ni poseen la infraestructura óptima para que la población haga uso de los mismos.

\footnotetext{
${ }^{18}$ Pese a que en los mapas se identifica a la Reserva de Punta Lara como parte de los espacios verdes, en el cálculo no se lo considera, por tratarse de un espacio al cual debiera otorgarse un tratamiento particular e integral que contemple su condición de Reserva Natural
} 

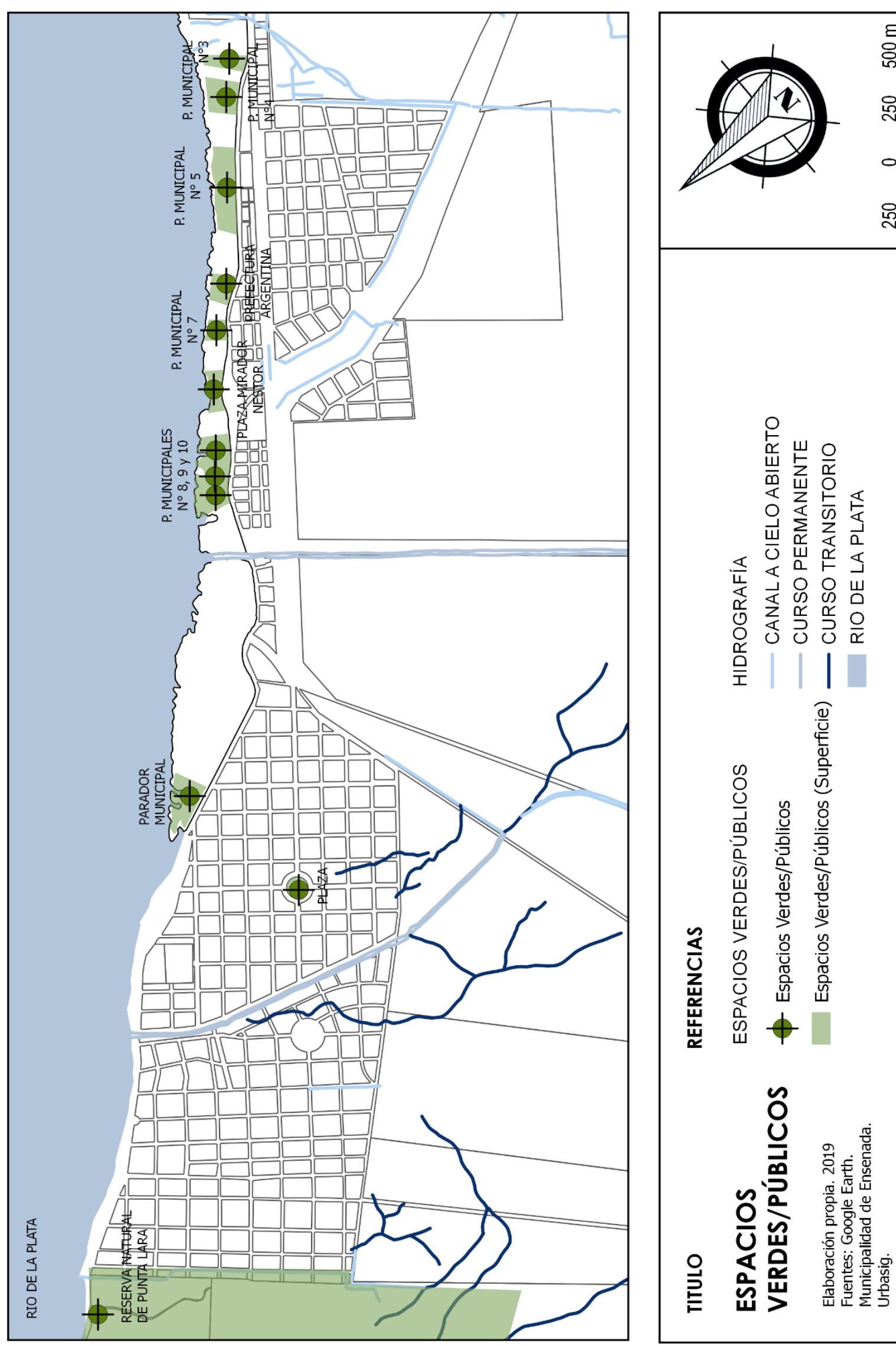

안

뜬 음

更岁

$0<\frac{1}{Q}$

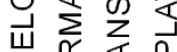

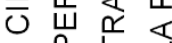

$\varangle \ll$

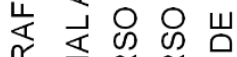

效

O

奠

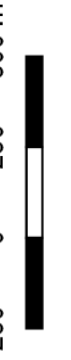

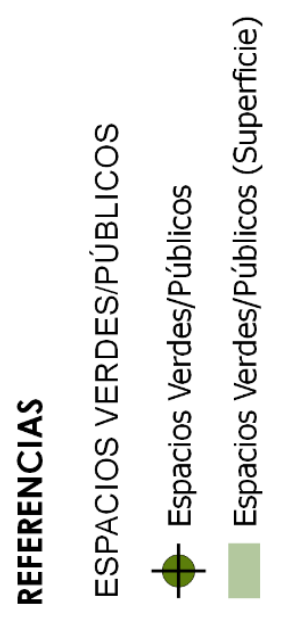

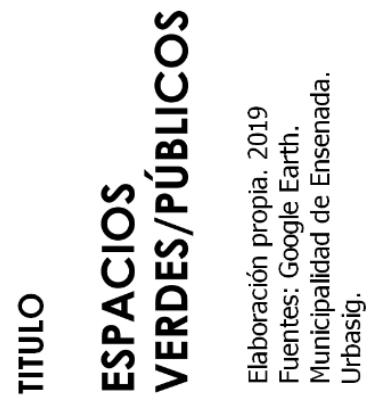




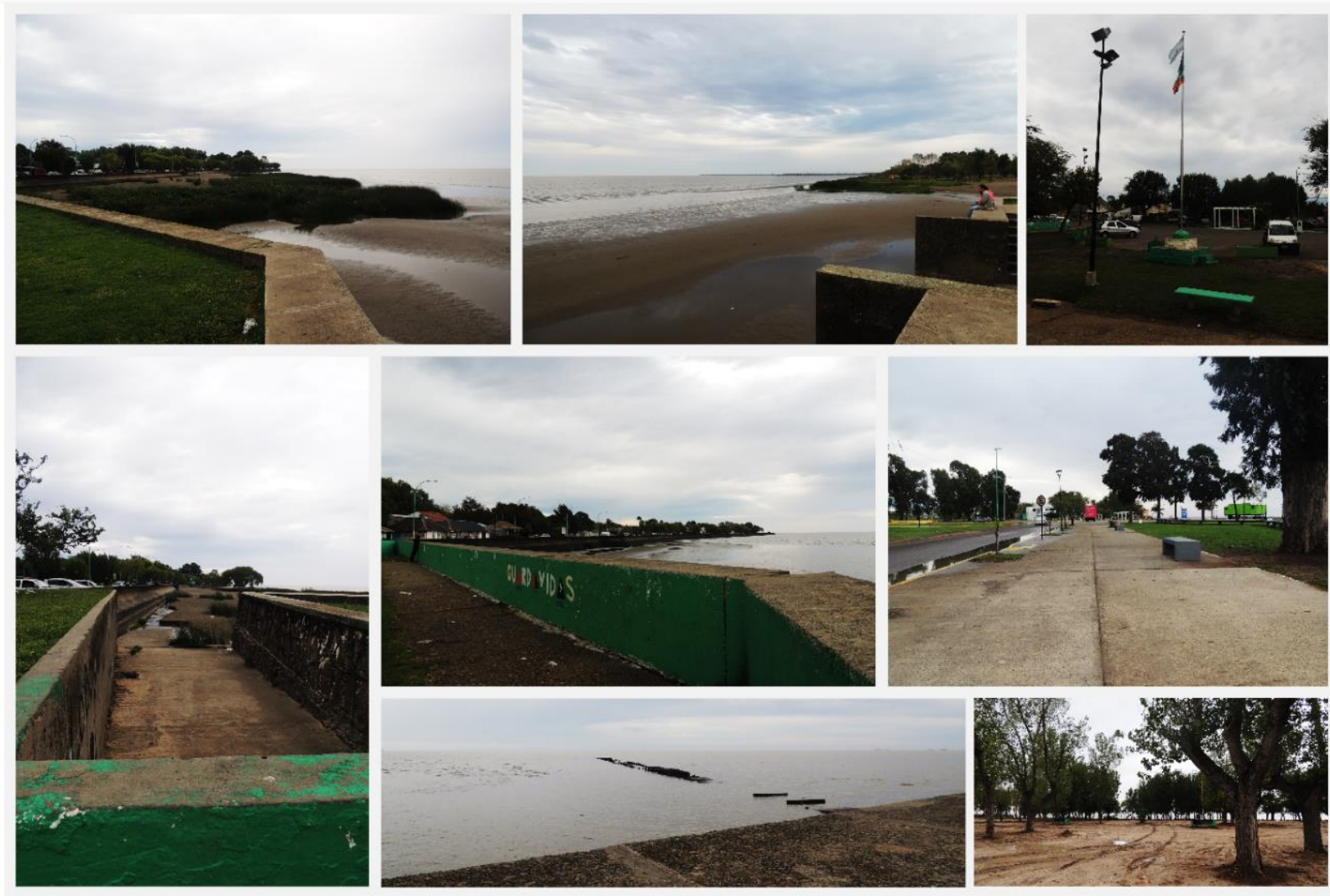

Figura 24. Fotos representativas Espacios Verdes Públicos. Fotografías Arq. Estefanía Jáuregui. 2018

A fin de evaluar la accesibilidad real de la población a estos espacios, se definieron, a través de las herramientas de análisis espacial "áreas de cobertura" o "buffers" de los mismos. De esta manera, se utilizaron estándares y recomendaciones internacionales ${ }^{19}$ que definen que, en una situación óptima, la población no debe encontrarse a más de 300 metros para plazas públicas y 600 metros para parques y otros espacios verdes de gran dimensión (se incluyeron en esta última categoría a los paradores municipales de la localidad de Punta Lara).

\begin{tabular}{l|ccc} 
& \multicolumn{3}{c}{ áreas de cobertura ("buffer") } \\
ESPACIOS VERDES PÚBLICOS & ФA & ФB & ФC \\
\hline Plazas & $300 \mathrm{~m}$ & $600 \mathrm{~m}$ & $>600 \mathrm{~m}$ \\
\hline Parques / Paradores Municipales & $600 \mathrm{~m}$ & $800 \mathrm{~m}$ & $>800 \mathrm{~m}$
\end{tabular}

Con estos valores, intersectando las áreas de influencia con las manzanas de la localidad, se definió cuáles de ellas contaban con la "cobertura" de los espacios verdes/públicos y considerando que se encontraban dentro del área de influencia cuando al menos una porción de su superficie quedaba contenida dentro del buffer. Se obtuvo como resultado el Mapa 6, que refleja estas situaciones.

\footnotetext{
${ }^{19}$ En relación a estas recomendaciones, el presente trabajo se apoya en el "Sistema de indicadores y condicionantes para ciudades grandes y medianas", desarrollado por el MAGRAMA, Agencia de Ecología Urbana de Barcelona y La Red de Redes de Desarrollo Local Sostenible (2010).
} 

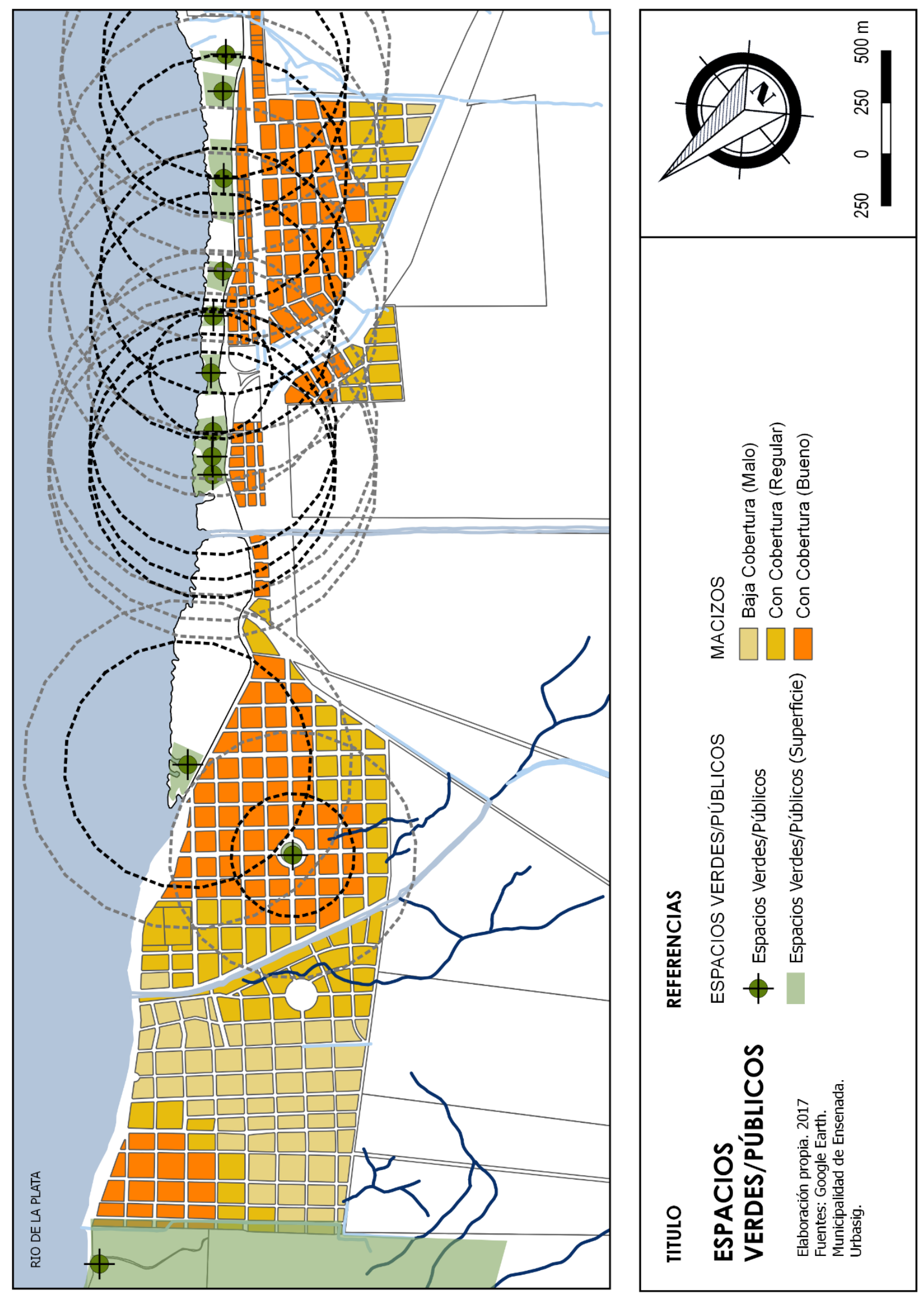
Una vez construido el mapa, se procuró realizar un recuento de la población que se encontraba en cada una de las áreas de cobertura (Figura 25).

\section{PCobSverde $=$ hab. $\Phi$ de cobertura}

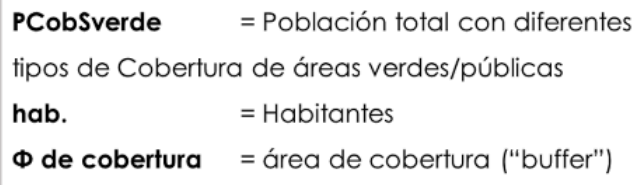

Figura 25. Modalidad de medición de población en área de cobertura espacios verdes/públicos. Elaboración propia. 2019

Con estos datos se definió que, del total de la población, 7009 habitantes (que representan 166 manzanas) poseían una cobertura adecuada de espacios verdes públicos, 2847 habitantes (un total de 83 manzanas) tenían una cobertura regular y el resto de la población no poseía cobertura o ésta era muy limitada. Es decir que, pese a que el indicador de espacios verdes por metro cuadrado da como resultado un valor elevado, solo un $61 \%$ de la población de la localidad tenía un acceso adecuado a este tipo de espacios en el territorio, y más del $10 \%$ de la población no contaba con ningún tipo de acceso a espacios verdes (Figura 26).

$\begin{array}{lcc}\text { indicador espacios verdes/públicos } & \\ \text { COBERTURA } & \text { MANZANAS } & \text { POBLACION } \\ \text { Baja Cobertura (Malo) } & 63 & 1549,6 \\ \text { Con Cobertura (Regular) } & 89 & 2847 \\ \text { Con Cobertura (Bueno) } & 179 & 7009,6 \\ \text { TOTAL } & \mathbf{3 3 1} & \mathbf{1 1 4 0 6}\end{array}$

Figura 26. Análisis de la cobertura de espacios verdes/públicos. Elaboración propia. 2019

En síntesis, estos datos permitieron reconocer una variedad importante de espacios verdes públicos en el área de estudio, que son utilizados por la población local y también por ciudadanos que provienen de otras regiones. En contraposición, pudo observarse una concentración de estos espacios en el borde costero y una continuidad de los mismos sólo en ese sector.

Sin embargo, en términos de la localidad en general, se observó una ruptura de esta continuidad, generando que los espacios verdes/públicos se localicen de forma dispersa y con diferentes grados de consolidación (espacios degradados, con menor cantidad de equipamientos, etc.). Así, la incorporación al análisis de esta particularidad, permite observar la existencia de áreas con grandes déficits de cobertura y diferentes grados de criticidad en el acceso a estos espacios.

\section{B | Análisis cualitativo del Indicador}

En relación al análisis cualitativo del indicador de espacios verdes/públicos y el uso que la población hace de los mismos, la primera apreciación producto del trabajo de campo y las visitas al área de estudio, permitió observar una gran concentración de población sobre el borde costero y, en menor cantidad, sobre otros espacios verdes (como Diagonal 74). Además, pudo identificarse una variedad de usuarios (ciudadanos junto a sus familias, con amigos, o incluso solos), lo cual permitió empezar a inferir el uso que se hace de los espacios verdes/públicos principalmente. 
En esta línea, el análisis de artículos periodísticos y el trabajo de campo, permitió distinguir que, en términos de la apropiación que la población hace de estos espacios verdes, existe una diversidad de usos y actividades que se desarrollan dentro de los mismos (Figura 27).

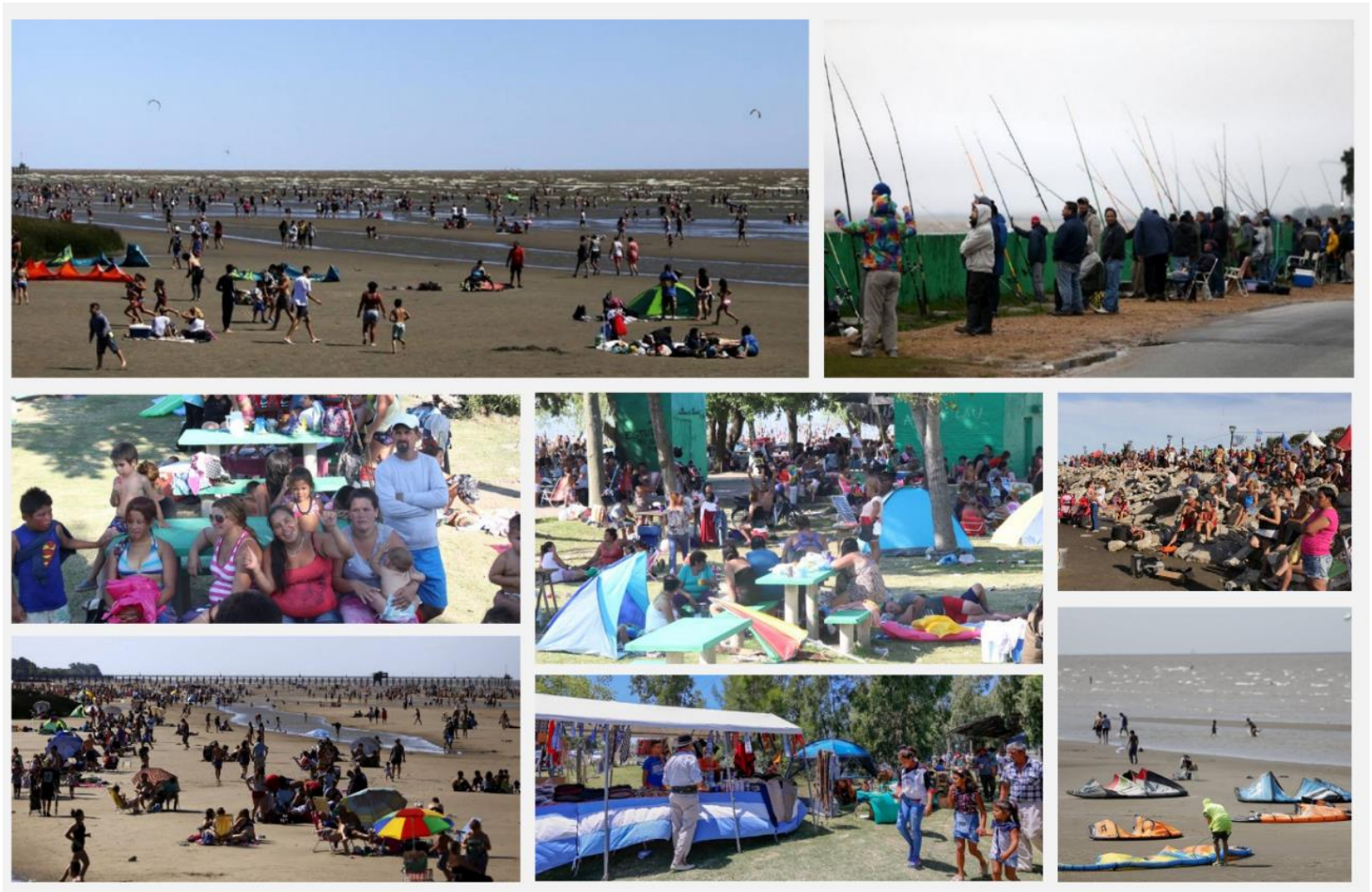

Figura 27. Imágenes representativas de diferentes usos del espacio verde público. Fuente: Diario NOTICIAS de Ensenada (http://www.noticiasensenada.com)

A modo de ejemplo, la zona de la plaza mirador Néstor Kirchner se utiliza como espacio de paso con la presencia de algunos juegos infantiles, mientras que las áreas verdes que se encuentran sobre el borde costero presentan otro tipo de equipamientos para el desarrollo de actividades que requieren de mayor extensión (se observan zonas equipadas con mesas y sillas, presencia de baños públicos, áreas de camping, entre otros).

Abundando en esta temática, al consultar a la población acerca del uso que realizan sobre estos espacios verdes públicos, en general la mayor parte de los encuestados (59\%) refiere realizar un uso regular y continuo sobre estos, acercándose con sus familias debido a que, como manifiestan, se han desarrollado durante el último tiempo numerosas mejoras que permiten un mejor aprovechamiento de los mismos ("vengo todo el tiempo, me encanta, sola o con la familia"). Otros indicaron que se acercan sólo a veces a los espacios públicos, en general con amigos, particularmente la población de menor rango de edad (representando un $27 \%$ de la muestra). Generalizando, un $86,5 \%$ de los encuestados hace uso de los espacios verdes/públicos, mientras que un $14 \%$ refirió no utilizarlos y dirigirse a otras áreas para el disfrute de este tipo de espacios (Figura 28). 


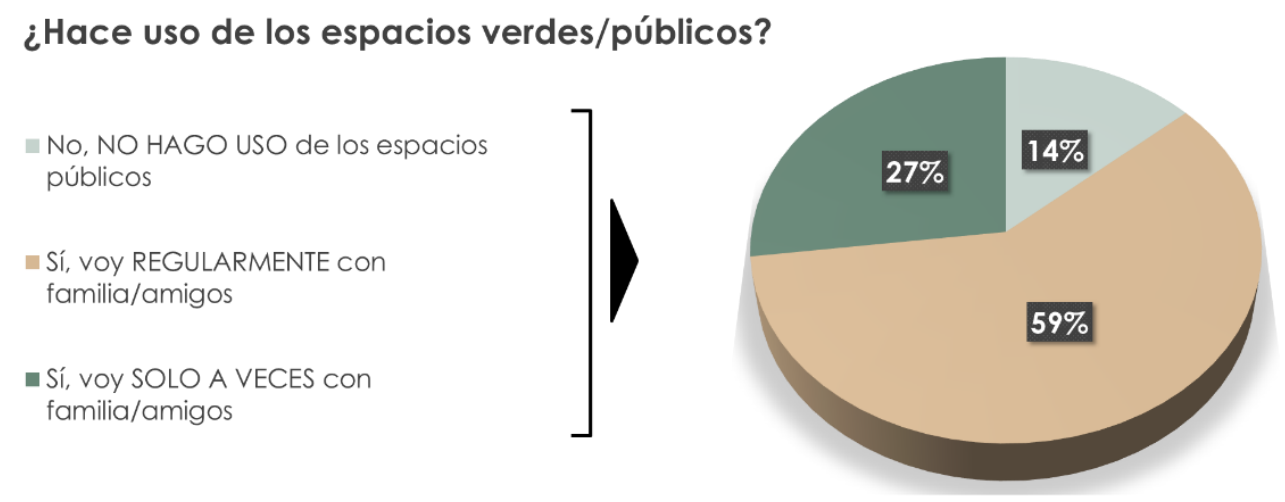

Figura 28. Resultados encuesta: Uso de los espacios verdes/públicos. Elaboración propia. 2019

De estos datos y la observación del uso que la población hace de los sectores, pudo inferirse que, efectivamente, se utilizan no sólo como lugares de recreación individual, sino como espacios de sociabilización, compartiendo momentos en familia y amigos. Además, identifican que la calidad de estos espacios es buena e incluso -pese a que no se brindaba como opción-, muy buena; nuevamente, apoyados en las intervenciones que se realizaron durante los últimos años ("antes no se podía venir acá") (Figura 29).
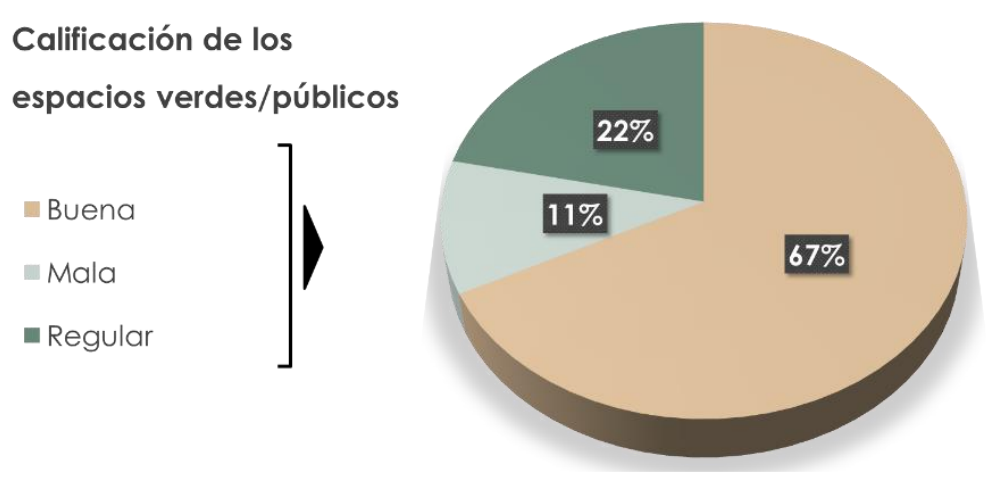

Figura 29. Resultados encuesta: Calificación de los espacios verdes/públicos. Elaboración propia. 2019

Sin embargo, la gran mayoría de los encuestados se refirieron al "espacio verde/público" como el borde costero, perdiendo entidad las plazas de la localidad (manifestando, por ejemplo, que "sólo hay una, y casi no tiene equipamientos"). En este sentido, puede verse enfatizada la concentración observada en los Mapas 5 y 6 , reforzando la idea de que existen sectores de la localidad que no se encuentran abastecidos con este tipo de espacios, presentando diferentes grados de criticidad.

En contraposición a esto, un punto interesante que pudo identificarse fue que las mayores críticas de la población no refirieron a la falta de espacios verdes públicos -ya que más del $60 \%$ de los encuestados considera que los espacios verdes/públicos resultan suficientes para la localidad, siempre contemplando que "cuanto más espacios verdes haya, mejor"-, sino a la calidad de los equipamientos de los mismos ("faltan tachos de basura, baños públicos, espacios para actividades deportivas al aire libre", entre otros). Además, se manifestaron cierta incomodidad y quejas acerca del uso del espacio público por parte de visitantes no residentes en la localidad de Punta Lara ("no mantienen el lugar", "no lo cuidan como nosotros", "hay mucha suciedad"); lo que permite reconocer un importante sentido de pertenencia al área, identificando principalmente al borde costero y los diferentes paradores sobre el mismo como "propios", lugares con los que se identifican, incluso, al ser consultados sobre los espacios de significación cultural -a los que haremos referencia en los siguientes apartados-. 
Puede verse en este punto como el contexto y la conformación histórica de la localidad le han impreso características particulares al espacio público, que los propios residentes reconocen y que, incluso, excede los límites de la localidad, generando que haya gran cantidad de población "no residente" que se acerca de visita debido, principalmente, a sus características de localidad costera y de recreación estacional (Ver Anexo II - Artículos Periodísticos).

Pese a esto, el porcentaje de población residente que indicó que estos espacios no resultan suficientes también fue importante (representado por un 38\% de los encuestados) (Figura 30) y en el análisis detallado pudo asociarse estas respuestas con la población que reside principalmente en el barrio de Villa del Plata, que, como puede observarse en el Mapa 6, posee una cobertura "buena" de espacios verdes/públicos por la cercanía que posee con el borde costero, pero no presenta consolidación de ningún tipo de espacio verde/público al interior del barrio.

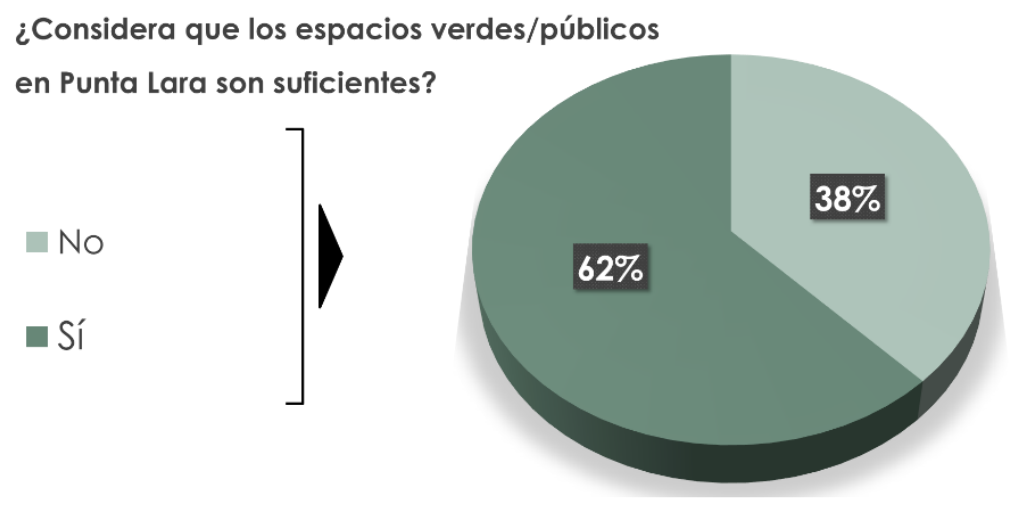

Figura 30. Resultados encuesta: Suficiencia/Insuficiencia de los espacios verdes/públicos. Elaboración propia. 2019

Un dato que la observación y el trabajo de campo permitieron identificar es que -a pesar de no estar contemplado dentro del análisis de la variable Ciudad Incluyente- existen otras inquietudes, ya que, por ejemplo, los encuestados manifiestan la necesidad de contar con mayor seguridad en toda la localidad y particularmente sobre el borde costero, fundamentalmente los días que se reciben visitantes sobre la localidad ("hay que poner más seguridad, sobre todo los fines de semana que viene mucha gente").

\section{C| Síntesis del Indicador}

La primera conclusión general, entonces, que puede obtenerse de la interpelación del análisis cuantitativo de este indicador a partir de las técnicas cualitativas, se relaciona con el acceso real de la población a los espacios verdes/públicos. Pese a que el análisis cuantitativo permitió definir que en términos espaciales el porcentaje de "cobertura" de estos espacios resulta limitado, observándose áreas con diferentes niveles de criticidad en relación a esto (con un 14\% de la población que no presenta ningún tipo de cobertura, en términos espaciales -Figura 26); al comparar estos datos con la percepción de la población, puede interpretarse que el uso de estos espacios no se encuentra sólo asociado a la distancia que existe a ellos, sino con los desplazamientos de la población hacia sitios deseados. Así, como fuera observado previamente, la población indica un elevado nivel de conformidad -en términos generales-con este tipo de espacios (Figura 30), considerando que resultan suficientes, aunque siempre valorando que podrían incorporarse nuevos espacios verdes. 
Además, en relación a uno de los interrogantes planteados como parte de la construcción metodológica, asociado al reconocimiento o no por parte de la población de estos espacios como "espacios de uso", pudo observarse -mediante la aplicación de técnicas cualitativas-, que la población efectivamente se apropia de estos espacios, desarrollando diferentes tipos de actividades en ellos y contemplándolos como espacios de sociabilización y disfrute, compartiendo actividades con familia y amigos, reforzando la concepción de Jane Jacobs de que deben ser estos los lugares que permitan el encuentro entre los miembros de la sociedad y los espacios que permitan la generación de vínculos. Más aún, al asociar este dato con la frecuencia con la que la población concurre a estos espacios, puede observarse que un porcentaje elevado de habitantes hace uso de los mismos regularmente.

En esta misma línea, la observación y el trabajo de campo, permitieron enfatizar el reconocimiento cuantitativo del uso que se hace de los espacios verdes/públicos, identificando usos diferenciados e incluso actividades públicas y gratuitas que se desarrollan sobre los mismos. Sumado a esto, que el disfrute de estos espacios de convivencia no es sólo por parte de los ciudadanos residentes, sino que, como fuera evaluado en el análisis del contexto, las características de la localidad la convierten en un atractivo para residentes de otras áreas y regiones, estableciéndose vínculos que exceden la localía.

Conjuntamente, la representación en mapas (Mapa 5) permitió identificar una concentración de gran cantidad de espacios verdes/públicos -así como actividades- sobre el borde costero. El desarrollo de las encuestas puso aún más el foco sobre este borde como concentrador de multiplicidad de situaciones, observándose que la población tiene una percepción mucho mayor de este espacio y se siente mucho más identificada con el mismo, diferente a la afinidad que genera con otros espacios verdes/públicos de la localidad. Así, puede observarse en este punto como los "puntalarenses" -como ellos mismos se reconocen- le otorgan una importancia mucho mayor a estos espacios, que la de ser simplemente un espacio verde/público, haciendo uso del mismo e identificándolo como un lugar de relevancia que le imprime características particulares a la localidad. 


\section{FICHA METODOLÓGICA}

\section{descripción}

El indicador verifica la existencia de espacios verdes/públicos en el área, para llevar a cabo diferentes actividades fundamentales para el desarrollo de la vida en la ciudad

\section{objetivo de la medición}

"La existencia de espacios de socialización y encuentro ayudan a la creación de vínculos entre las personas. Es este sentimiento de comunidad, de responsabilidad social, el que hace que la gente se sienta segura" (Jane Jacobs, 1961)

Se trata de un descriptor importante, debido a que las ciudades deben garantizar espacios públicos libres y accesibles para fomentar la convivencia y el encuentro de los ciudadanos

\section{preguntas conductoras}

¿Existen suficientes espacios públicos para el sector? ¿Se encuentran estos espacios bien distribuidos? ¿En qué condiciones se encuentran? ¿Son utilizables? ¿La sociedad los reconoce como espacios públicos de uso? ¿Cómo están equipados? ¿Se observa la presencia de vegetación?

\section{limitaciones del indicador}

El análisis que se realiza es a partir de técnicas cuantitativas que se interpelan mediante el uso de técnicas cualitativas que aporten la visión de actores residentes en el área de estudio

\section{modalidad de medición - tratamiento del dato}

1. La fórmula que se aplicará para la medición inicial será:

\begin{tabular}{|c|c|c|}
\hline Sverdet $=\sum$ & SverdeP & $\begin{array}{ll}\text { Sverdet } & =\text { Superficie Verde Total }(\mathrm{en} \mathrm{m} 2) \\
\Sigma \text { SverdeP } & =\text { Sumatoria de Superficies de }\end{array}$ \\
\hline & ha & $\begin{array}{l}\text { Espacios Verdes/Públicos identificados (en m2) } \\
\text { hab. = Habitantes }\end{array}$ \\
\hline
\end{tabular}

* Se tomará como parámetro para la evaluación, lo definido en el Art. 13 de Decreto-Ley 8912/77, en el que se define que "Los espacios verdes o libres públicos de un núcleo urbano serán dimensionados en base a la población potencial tope establecida por el Plan de Ordenamiento para el mismo, adoptando un mínimo de diez metros cuadrados $\left(10 \mathrm{~m}^{2}\right)$ de área verde o libre po

2. Luego se procurará evaluar el grado de cobertura de estos espacios, según los siguientes parámetros:

\section{ESPACIOS VERDES PÚBLICOS}

Plazas

Parques / Paradores Municipales áreas de cobertura ("buffer")

$\begin{array}{ccc}\text { DA } & \Phi B & \Phi C \\ 300 \mathrm{~m} & 600 \mathrm{~m} & >600 \mathrm{~m} \\ 600 \mathrm{~m} & 800 \mathrm{~m} & >800 \mathrm{~m}\end{array}$

PCobSverde = Población total con diferentes

tipos de Cobertura de áreas verdes/públicas

hab. $\quad=$ Habitantes

\$ de cobertura = área de cobertura ("buffer")
3. Se definirá la cantidad de población que se encuentra dentro del área de cobertura, reconociendo diferentes tipos de situaciones de acuerdo a lo siguiente:

\begin{tabular}{|c|c|c|c|}
\hline \multirow[t]{2}{*}{ PCobSverde = } & \multirow{2}{*}{$\frac{\text { hab. }}{\Phi \text { de cobertura }}$} & \multicolumn{2}{|c|}{$\begin{array}{l}\text { PCobSverde = Población total con diferentes } \\
\text { tipos de Cobertura de áreas verdes/públicas }\end{array}$} \\
\hline & & $\begin{array}{l}\text { hab. } \\
\Phi \text { de cobertura }\end{array}$ & $\begin{array}{l}=\text { Habitantes } \\
=\text { área de cobertura ("buffer") }\end{array}$ \\
\hline
\end{tabular}

4. Se interpelarán los resultados obtenidos a partir de la percepción de población residente en el área de estudio, mediante el desarrollo de encuestas

\section{escala de medición}

El indicador "espacio público" se analizará tanto en la escala MACRO (totalidad de la población y relación con el espacio público) como en la escala MICRO (análisis por manzana)

\section{fuentes de información}

Visualizadores: OpenStreet Map / Street View Análisis de Imagenes Satelitales: Google Earth Normativas Municipales

Encuestas: Población residente en el área de estudio

\section{variable dimensión \\ CIUDAD INCLUYENTE RECREACIÓN}

factibilidad de análisis del indicador

ALTA 


\subsubsection{Indicador de CENTROS DEPORTIVOS RECREATIVOS}

En el marco de garantizar el derecho a la ciudad para la población, debe contemplarse también la necesidad de facilitar, promover y mantener espacios para la práctica de actividades físicas y deportivas; entendiendo que el deporte aporta al desarrollo personal y social de los ciudadanos.

Así, con el análisis de este indicador se procuró observar la posibilidad de los ciudadanos, independientemente de sus características socio-económicas, de acceder a una dotación adecuada de equipamientos deportivos. El indicador tuvo como objetivo observar el acceso a centros deportivos, de acceso público para la población, así como un reconocimiento de los equipamientos deportivos de acceso restringido.

Las preguntas conductoras para el estudio de este indicador fueron: ¿Hay centros deportivos o espacios para el desarrollo de actividades deportivas de libre acceso? ¿Son utilizados por la sociedad, o se encuentran en desuso? ¿La sociedad los reconoce como propios?

\section{A | Análisis cuantitativo del Indicador}

Al igual que el indicador de espacios verdes/públicos, el análisis de los centros deportivos en el sector conllevó inicialmente a la localización de estos espacios en el territorio, diferenciando cuáles de estos eran de acceso público y cuáles de ellos de acceso restringido (Mapa 7).

Los centros deportivos de acceso público tienen características de pequeñas canchas descubiertas en las que pueden realizarse diferentes actividades. Debido a que todos los habitantes pueden acceder a estos espacios, sin importar su condición socio-económica o su pertenencia o no a algún sindicato, se considera un radio de cobertura de 600 metros.

Por el contrario, los centros deportivos de acceso restringido, corresponden en su mayoría a espacios de sindicatos y clubes, pudiendo desarrollarse múltiples actividades en su interior (presencia de canchas de futbol, de tenis, piletas descubiertas, entre otras). Como sucediera con el análisis del indicador de espacios verdes/públicos, no se contemplarán estos centros deportivos en las indagaciones, debido a que se restringe el acceso de la población, limitando la posibilidad de definir los habitantes que se encuentran abastecidos por los mismos.

\begin{tabular}{|c|c|c|c|c|}
\hline \multirow{2}{*}{\multicolumn{2}{|c|}{ CENTROS DEPORTIVOS RECREATIVOS }} & \multicolumn{3}{|c|}{ áreas de cobertura ("buffer") } \\
\hline & & $\Phi A$ & $\Phi B$ & $\Phi C$ \\
\hline Canchas deportivas al aire libre & de acceso público & $600 \mathrm{~m}$ & $800 \mathrm{~m}$ & $>800 \mathrm{~m}$ \\
\hline Pequeños complejos descubiertos & de acceso público & $600 \mathrm{~m}$ & $800 \mathrm{~m}$ & $>800 \mathrm{~m}$ \\
\hline
\end{tabular}

A partir de estas distancias, se definió cuáles de las manzanas contaban con la "cobertura" de los centros deportivos recreativos y con este análisis se construyó el Mapa 8. 

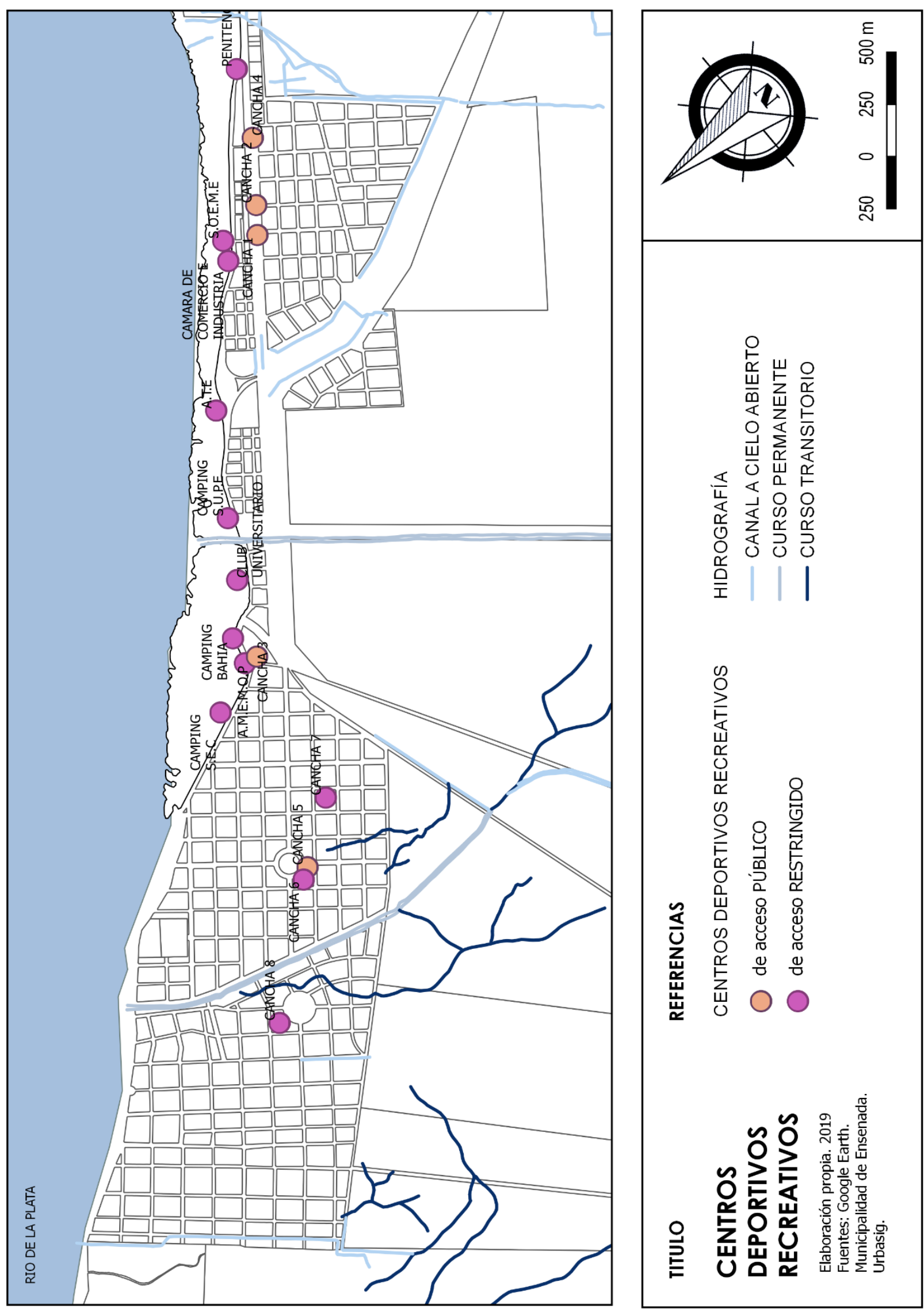

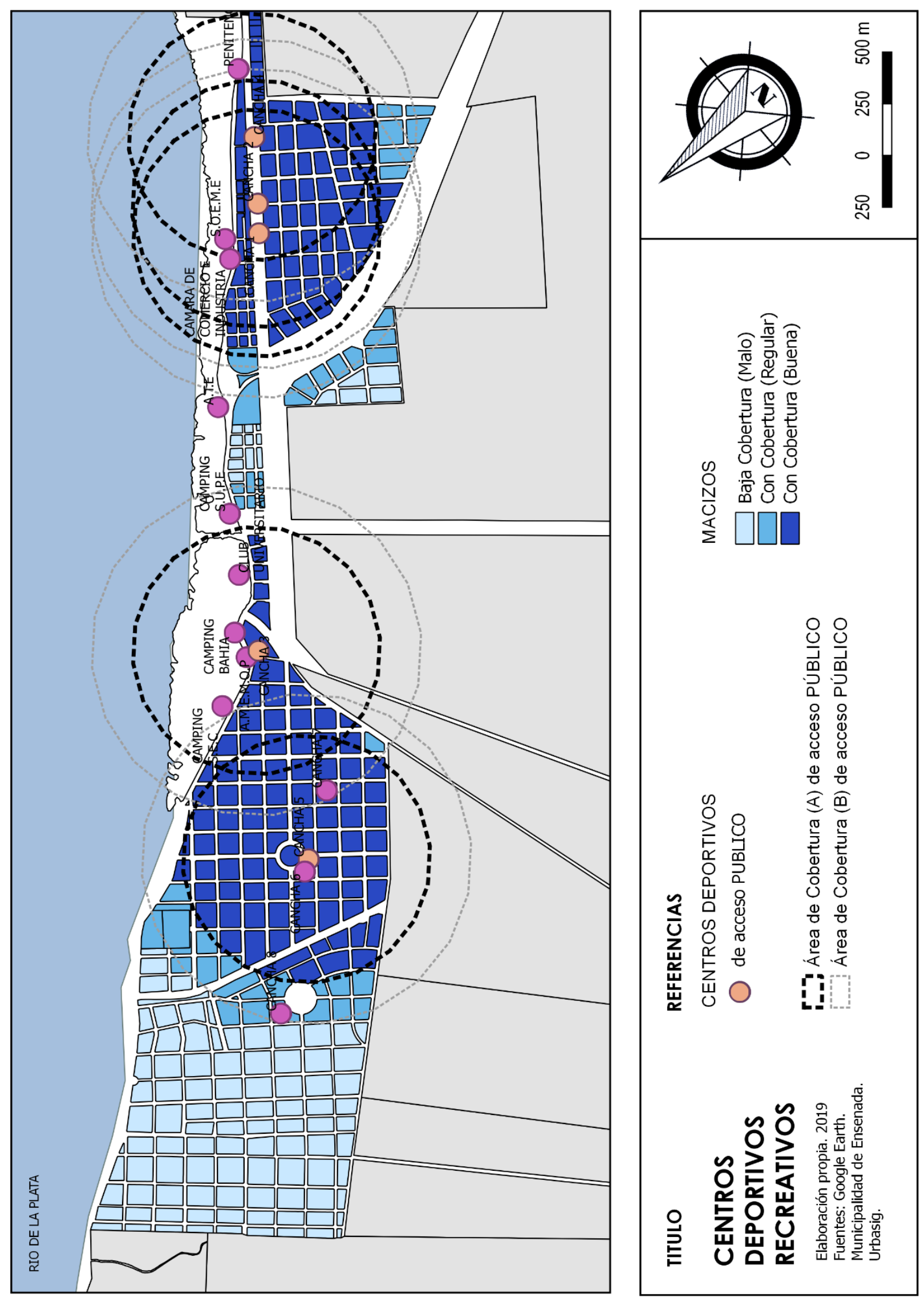
A partir de estos datos, se realizó el recuento de la población que se encontraba en cada una de las áreas de cobertura (Figura 32)

\section{PCobCdep $=$ hab. $\Phi$ de cobertura}

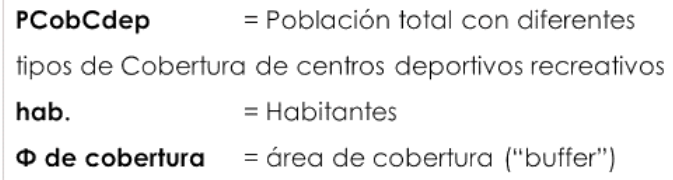

Figura 32. Modalidad de medición de análisis de población en área de cobertura Centros Deportivos Recreativos. Elaboración propia. 2019

Este análisis permitió reconocer que 7119 habitantes (que representan 177 manzanas) poseían una cobertura adecuada de centros recreativos deportivos, 1352 habitantes (44 manzanas) una cobertura regular y el resto de la población poseía baja cobertura. En términos porcentuales, esto representó un $54 \%$ de población con cobertura y acceso pleno a estos espacios, un 13\% con un acceso regular (debido a las distancias a recorrer para acceder a ellos) y un 33\% de los habitantes con baja cobertura (Figura 33), siendo este último un porcentaje importante de población que presenta dificultades para satisfacer necesidades relacionadas al desarrollo de actividades deportivas.

indicador centros recreativos/deportivos

\section{COBERTURA}

Baja Cobertura (Malo)

Con Cobertura (Regular)

Con Cobertura (Bueno)

TOTAL

\section{MANZANAS POBLACION}

$\begin{array}{cc}110 & 2935 \\ 44 & 1352 \\ 177 & 7119 \\ \mathbf{3 3 1} & \mathbf{1 1 4 0 6}\end{array}$
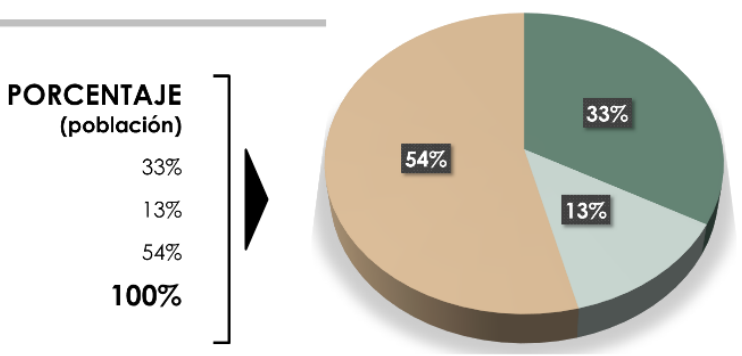

Figura 33. Análisis de la cobertura de centros recreativos/deportivos. Elaboración propia. 2019

\section{B | Análisis cualitativo del Indicador}

El estudio a partir de técnicas cualitativas en relación al indicador centros deportivos, permitió reconocer un uso espontáneo de algunos espacios para el desarrollo de actividades deportivas, principalmente sobre el borde costero, pese a que existen sectores que no se encuentran plenamente equipados para tal fin. Sin embargo, en términos de la apropiación que la población hace de las zonas destinadas a estos usos, más del $75 \%$ de los encuestados manifestó no participar de ningún tipo de actividad deportiva en centros municipales de la localidad, sino que en general deben trasladarse (Figura 34).

Estas expresiones resaltan aún más las consideraciones realizadas en el análisis cuantitativo, que daban cuenta de una gran cantidad de población que habita en áreas que no presentan ningún tipo de cobertura de estos servicios (un 33\% de la población); por ende, deben desarrollar las actividades deportivas en otras áreas.

Tomando esto en consideración, se buscó indagar acerca de cuáles eran esas áreas o localidades a las que la población se dirigía para acceder a estos servicios. En este caso, los encuestados manifestaron que debían trasladarse en general a la localidad de Ensenada o incluso, en ocasiones, a los partidos aledaños (principalmente el partido de La Plata), debido a que allí cuentan con centros especializados para el desarrollo de actividades deportivas, así como mayores ofertas de servicios y frecuencias. 


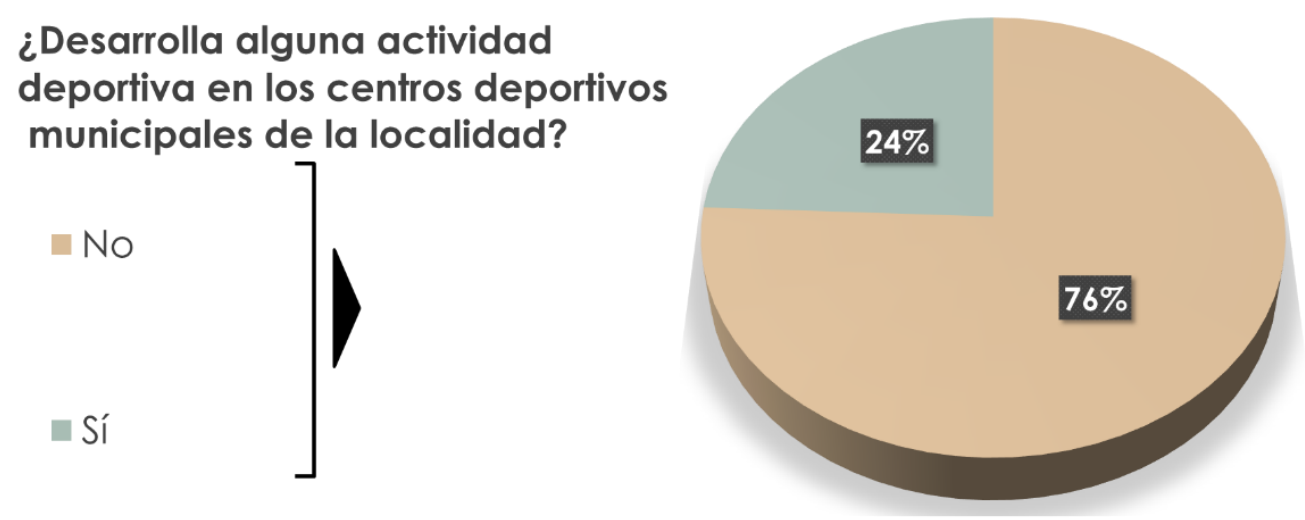

Figura 34. Resultados encuesta: Desarrollo de actividades deportivas en centros municipales. Elaboración propia. 2019

Así, la mayoría de los encuestados refirió que estos centros, principalmente los localizados en la localidad de Ensenada, podían calificarse como "buenos" (un 72\% de los encuestados), debido a que brindaban actividades interesantes y a las que, en ocasiones, no podrían acceder de otra forma; y un 20\% los calificó como "regulares" (Figura 35). El centro más identificado en relación a este punto, fue el Polideportivo Municipal de Ensenada, localizado en la calle Ortiz de Rosas y pasaje Cabo Verde, en el que pueden desarrollarse diferentes actividades deportivas de forma gratuita (handball, boxeo, vóley, judo, entre otras).

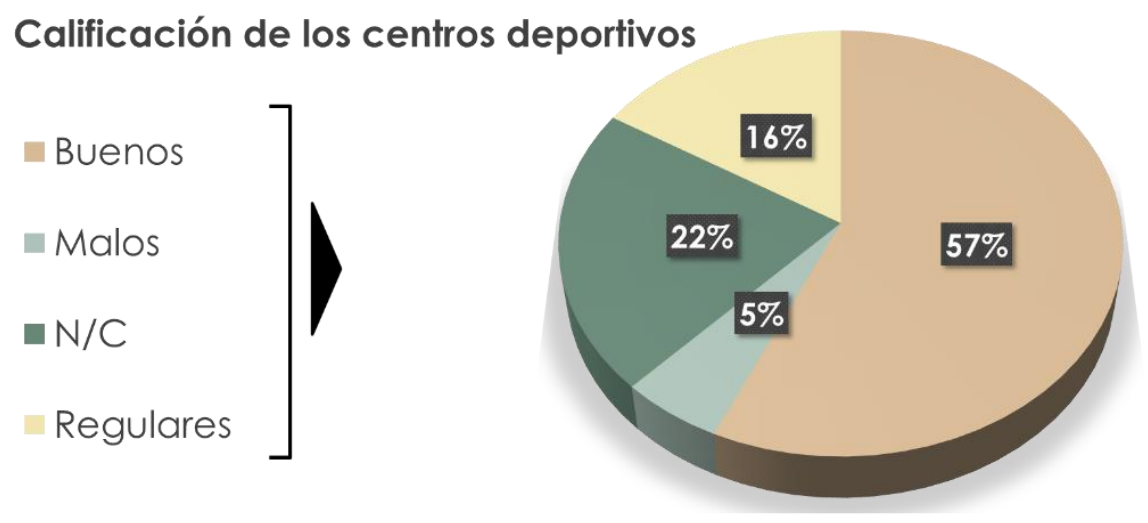

Figura 35. Resultados encuesta: Calificación centros deportivos municipales. Elaboración propia. 2019

Un porcentaje de los encuestados manifestó, sin embargo, valorar las actividades deportivas al aire libre que pueden realizarse sobre el borde costero, y el desarrollo de una colonia de vacaciones municipal en el Complejo Eva Perón, destinada no sólo a los niños de la localidad, sino también a los adultos mayores, en la que "los grupos se integran y realizan distintas actividades, en las piletas del Complejo, en el río, o bien haciendo manualidades, o practicando deportes"20

Con estas cuestiones presentes, se consultó a la población, cuáles consideraban que debían ser las mejoras propuestas en relación a este indicador, a fin de identificar si los espacios para el desarrollo de actividades deportivas resultaban suficientes o acordes a las necesidades de la población.

Las percepciones de los encuestados en cuanto a estas mejoras, varían entre la necesidad de mejorar las instalaciones existentes (opción elegida por el 14\% de los encuestados) y la posibilidad de brindar mayor cantidad de actividades y servicios en los espacios de la localidad (17\% de los encuestados se inclinó por esta opción).

\footnotetext{
${ }^{20}$ Obtenido de: https://www.ensenada.gov.ar/siguen-las-actividades-en-la-colonia-de-integracion-municipal/
} 
Otras mejoras se vinculan con la necesidad de construir mayor cantidad de centros deportivos en la localidad que permitan el desarrollo de actividades gratuitas sin necesidad de trasladarse a otras localidades; siendo esta última la opción más seleccionada por el 68.9\% de los encuestados ("faltan algunos lugares para hacer deportes, porque si no, tenemos que ir a otro lado") (Figura 36).

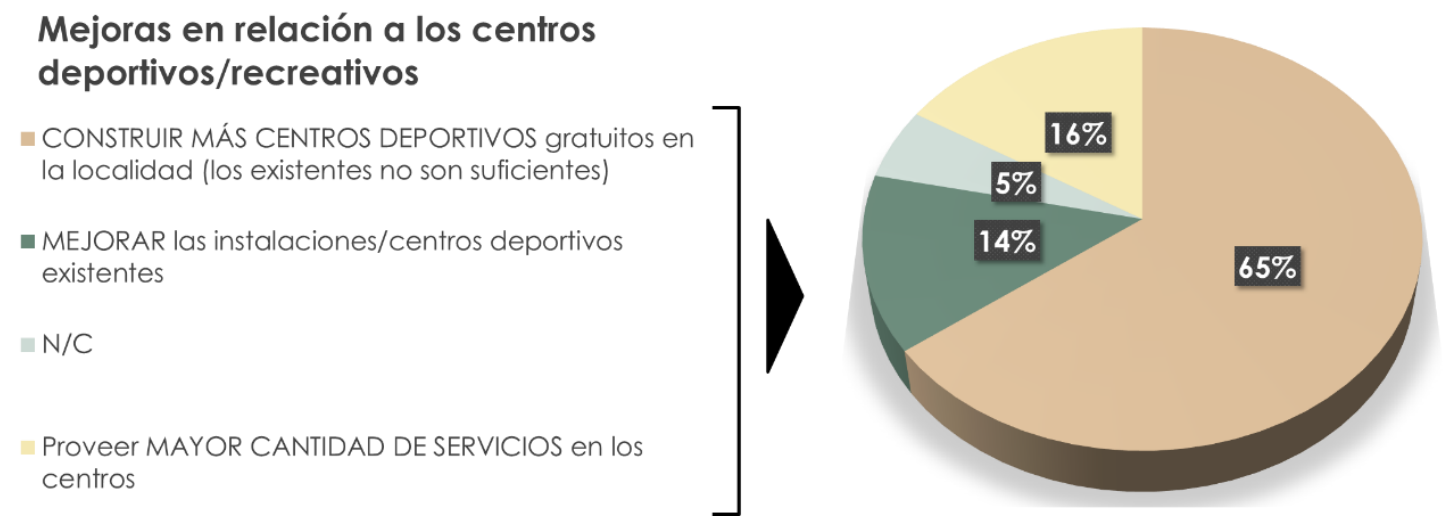

Figura 36. Resultados encuesta: Mejoras en relación a centros deportivos. Elaboración propia. 2019

\section{C| Síntesis del Indicador}

En síntesis, debido a que la práctica del deporte está supeditada a la cantidad y diversidad de las instalaciones y acceso por parte de los ciudadanos a las mismas, el estudio de este indicador permitió observar que existe efectivamente una variedad de equipamientos deportivos y centros para el desarrollo del deporte, tanto de acceso público como de acceso restringido.

Sin embargo, en términos espaciales, se reconoció una mayor concentración de la oferta de estos espacios sobre la zona más cercana al borde costero, y algunos establecimientos dispersos en el resto de la localidad, limitando en cierta forma la cobertura de estos espacios y el acceso de la población a los mismos. Más aún, si solo se considera el acceso a los espacios de acceso público -sin contemplar aquellos de acceso restringido- esa cobertura es mucho menor.

Así, al interpelar el análisis cuantitativo con la percepción de la población, pudo inferirse que coinciden casi plenamente los datos observados con la visión de los habitantes. En esta línea, pese a que las distancias que la población suele recorrer para acceder a actividades deportivas gratuitas son accesibles, hay una necesidad no resuelta en la propia localidad y los ciudadanos consideran que deberían poder satisfacerla en un espacio cercano a su lugar de residencia; sobre todo por los costos que generan tanto los traslados, como el abono para el desarrollo de actividades en otros centros de acceso restringido. 


\section{FICHA METODOLÓGICA}

\section{descripción}

El indicador observa el acceso a centros deportivos, de acceso público para la población, y un reconocimiento de los equipamientos deportivos de acceso restringido

\section{objetivo de la medición}

Con el análisis de este indicador se procuraba observar la posibilidad de los ciudadanos, independientemente de sus características socio-económicas, de acceder a una dotación adecuada de equipamientos deportivos, mediante un diagnóstico cuantitativo de los equipamientos en el sector. El indicador observa el acceso a centros deportivos, de acceso público para la población, y un reconocimiento de los equipamientos deportivos de acceso restringido

\section{preguntas conductoras}

\section{limitaciones del indicador}

¿Hay centros deportivos o espacios para el desarrollo de actividades deportivas de libre acceso?

¿Son utilizados, o se encuentran en desuso? ¿La sociedad los reconoce como propios?

El análisis que se realiza es a partir de técnicas cuantitativas que se interpelan mediante el uso de técnicas cualitativas que aporten la visión de actores residentes en el área de estudio

\section{modalidad de medición - tratamiento del dato}

1. Inicialmente se procurará evaluar el grado de cobertura de estos espacios, según los siguientes parámetros:

\begin{tabular}{llccc} 
& \multicolumn{3}{c}{ áreas de cobertura ("buffer") } \\
\cline { 2 - 4 } CENTROS DEPORTIVOS RECREATIVOS & ФA & ФB & ФC \\
\hline Canchas deportivas al aire libre & de acceso público & $600 \mathrm{~m}$ & $800 \mathrm{~m}$ & $>800 \mathrm{~m}$ \\
\hline Pequeños complejos descubiertos & de acceso público & $600 \mathrm{~m}$ & $800 \mathrm{~m}$ & $>800 \mathrm{~m}$ \\
\hline Polideportivos cubiertos & de acceso restringido & $300 \mathrm{~m}$ & $600 \mathrm{~m}$ & $>600 \mathrm{~m}$
\end{tabular}

2. Con estos parámetros se elaborará el mapa y luego se definirá la cantidad de población que se encuentra dentro del área de cobertura, reconociendo diferentes tipos de situaciones de acuerdo a lo siguiente:

\begin{tabular}{|c|c|c|c|}
\hline \multirow[t]{2}{*}{ PCobCdep = } & hab. & $\begin{array}{l}\text { PCobCdep } \\
\text { tipos de Cobertur }\end{array}$ & $\begin{array}{l}\text { = Población total con diferentes } \\
\text { a de centros deportivos recreativos }\end{array}$ \\
\hline & $\Phi$ de cobertura & $\begin{array}{l}\text { hab. } \\
\Phi \text { de cobertura }\end{array}$ & $\begin{array}{l}=\text { Habitantes } \\
=\text { área de cobertura ("buffer") }\end{array}$ \\
\hline
\end{tabular}

3. Se interpelarán los resultados obtenidos a partir de la percepción de población residente en el área de estudio, mediante el desarrollo de encuestas

\section{escala de medición}

El indicador "centros deportivos recreativos" se analizará en la escala MICRO (análisis por manzana)

\section{fuentes de información}

Visualizadores: OpenStreet Map / Street View Análisis de Imagenes Satelitales: Google Earth Normativas Municipales

Encuestas: Población residente en el área de estudio

$\begin{array}{lll}\text { variable } & \text { dimensión } & \text { factibilidad de análisis del indicador } \\ \text { CIUDAD INCLUYENTE } & \text { RECREACIÓN } & \text { ALTA }\end{array}$

Figura 37. Ficha metodológica análisis indicador "Centros Deportivos Recreativos". Elaboración propia. 2019 


\subsubsection{Indicador de CENTROS CULTURALES}

La evaluación de este indicador estuvo relacionada con el reconocimiento de que -en pos de alcanzar un pleno grado de satisfacción del derecho a la ciudad-, la población debe poder participar de la vida cultural $y$, a tal fin, debe contar con espacios adecuados para el desarrollo de actividades de este tipo; entendiendo a la cultura como una actividad importante para la sociedad y como un conjunto de normas y valores que guían muchas de las acciones humanas.

Otro de los derechos que debe garantizarse es el de la libre expresión de manifestaciones culturales; en especial de aquellas que refuercen el sentido de identidad y pertenencia a un barrio/comunidad, contribuyendo al proceso de desarrollo de los territorios.

En este sentido el indicador procuró verificar la existencia de centros culturales de fomento de estas actividades y también evaluar la existencia o no de expresiones artísticas que generaran identidad al sector por su grado de significación. Se buscó conducir el análisis del indicador a partir de las siguientes preguntas: ¿Hay centros para el desarrollo / fomento de actividades culturales? ¿La población hace uso de los mismos? ¿Hay murales que se enfoquen en la identidad del barrio? ¿Existen expresiones artísticas en el sector? ¿Se observan espacios de relevancia arquitectónica?

\section{A | Análisis cuantitativo del Indicador}

Tomando estas cuestiones como parámetro, se reconocieron los siguientes centros culturales, hitos, monumentos, espacios arquitectónicos con significancia para el área de estudio:

\section{Centros culturales}

Complejo "Eva Perón"

Centro Vecinal "Punta Lara"

Centro Cultural "Abuelos de Palacio Piria"
Hitos, Monumentos, Espacios de Significación

Monolito "Hito Punta Lara"
Monumento Silvio Pettirossi
Pérgola "Stella Maris"
Club Universitario
Iglesia "Stella Maris"
Plaza Mirador "Néstor Kirchner"
Policía de la Provincia de Buenos Aires
Hotel "S.U.P.E"
Diagonal 74

Una vez identificados se localizaron en el espacio, lo que permitió reconocer que, nuevamente, los centros culturales aparecen en el área central del sector de estudio, sobre la zona costera, como puede observarse en el Mapa 9. Los espacios de significación cultural, pese a encontrarse distribuidos por todo el recorte territorial, también se presentan levemente concentrados sobre el borde costero, reafirmando la concepción de que es este borde costero el que otorga múltiples características identitarias y estructurantes al sector de estudio (Figura 38). 

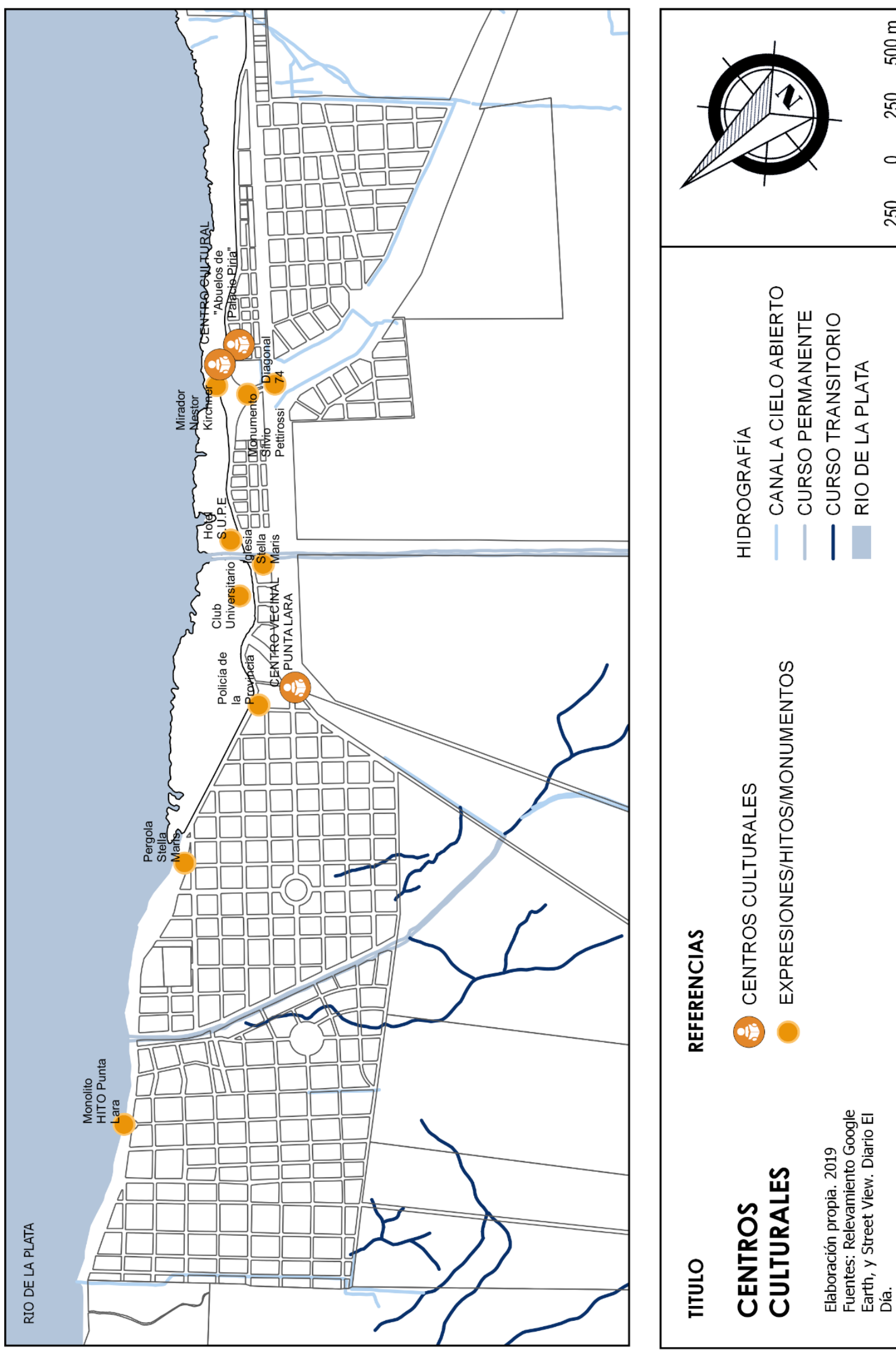

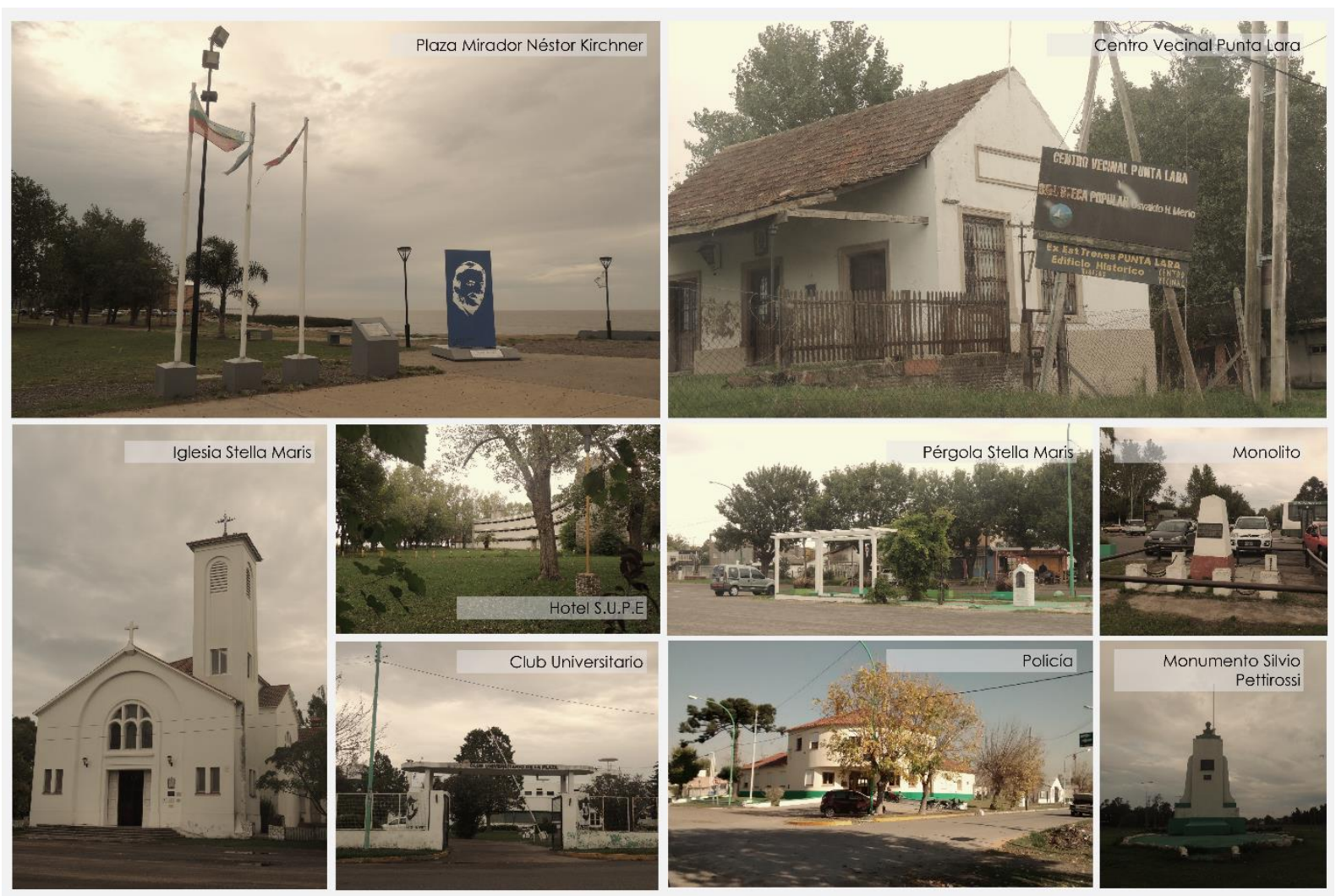

Figura 38. Fotos representativas Centros Culturales y Espacios de Significación Cultural. Fotografías Arq. Estefanía Jáuregui. 2018

Para el análisis de este indicador, se diferenciaron los centros culturales propiamente dichos de aquellos espacios, expresiones o hitos que tienen una significación para la comunidad en su totalidad. En este sentido, se tomaron como distancias de cobertura óptima de los centros culturales 600 metros, 800 metros para una cobertura regular y mayores distancias se interpretaron como una ausencia de cobertura.

\begin{tabular}{|c|c|c|c|}
\hline \multirow[b]{2}{*}{ CENTROS CULTURALES } & \multicolumn{3}{|c|}{ áreas de cobertura ("buffer") } \\
\hline & $\Phi A$ & $\Phi B$ & $\Phi C$ \\
\hline de acceso público & $600 \mathrm{~m}$ & $800 \mathrm{~m}$ & $>800 \mathrm{~m}$ \\
\hline Hitos/Monumentos/Expresiones/ Edificios & \multicolumn{3}{|c|}{ Significación para el total de la localida } \\
\hline
\end{tabular}

Con estos parámetros, se estudió el radio de influencia de estos espacios en relación a la comunidad, obteniendo como resultado el Mapa 10. 

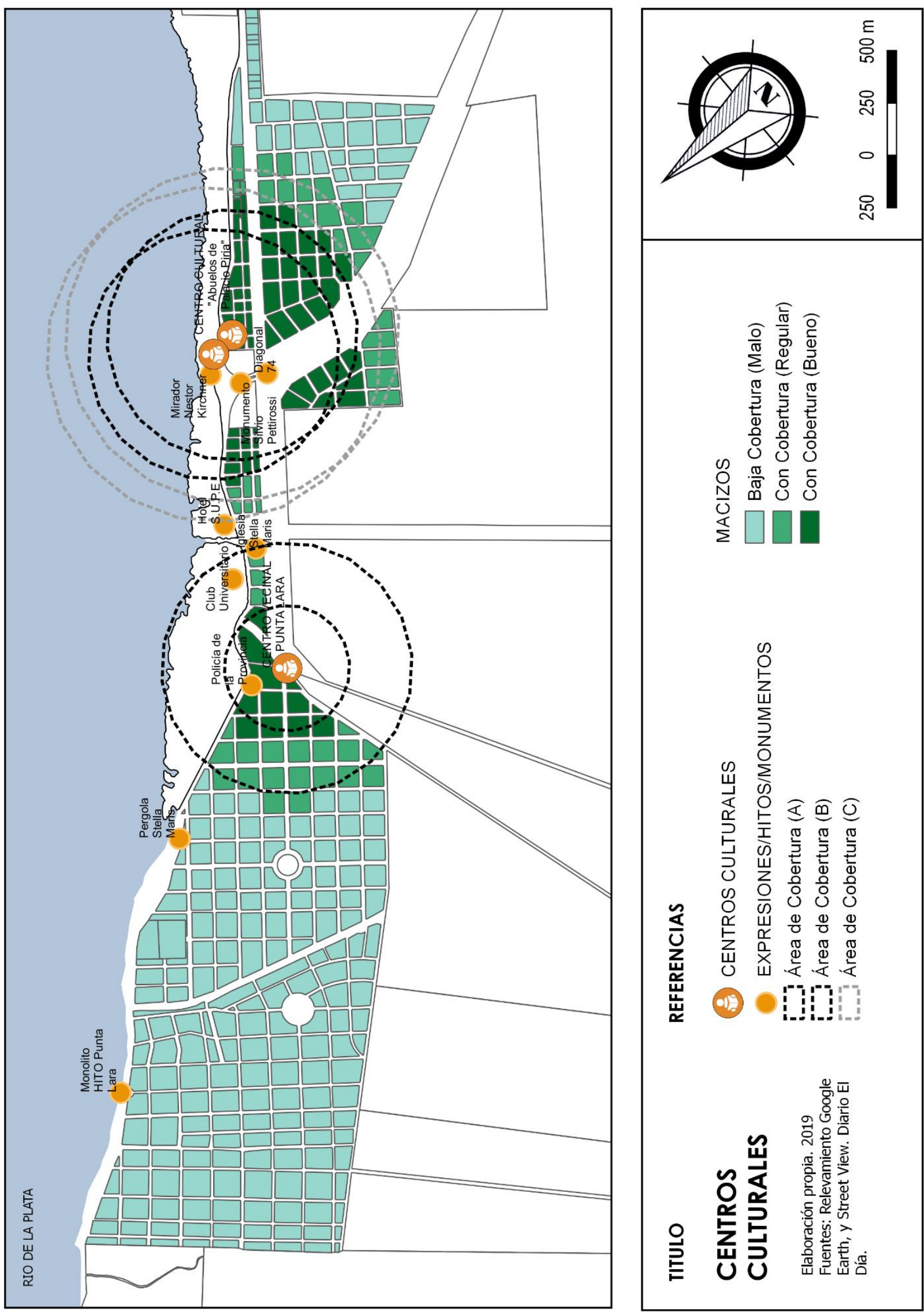
A partir de este mapa, el cómputo de la cantidad de población que se encontraba dentro del área de cobertura se desarrolló mediante la fórmula que fuera aplicada en el análisis de los indicadores previos (Figura 39)

PCobCcult $=$

hab.

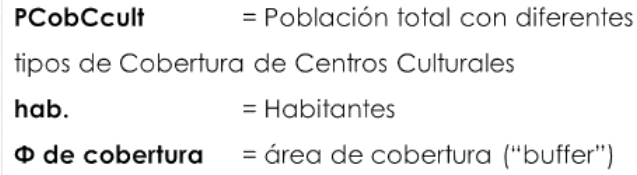

Figura 39. Modalidad de medición de análisis de población en área de cobertura Centros Culturales. Elaboración propia. 2019

La interpretación de los resultados obtenidos permitió reconocer un total de 7000 habitantes distribuidos en 214 manzanas del sector de estudio (representando más de la mitad de la población) con baja cobertura de estos espacios. Sólo un 21\% de la población -2355 habitantes- contaba con una cobertura buena de estos espacios y un 18\% con cobertura regular -2020 habitantes- (Figura 40).

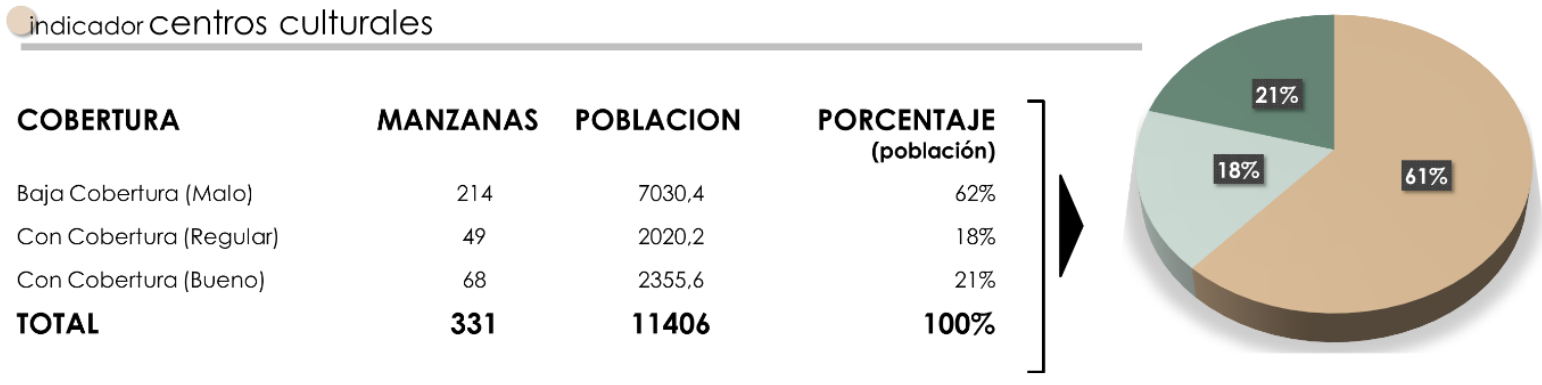

Figura 40. Análisis de la cobertura de centros culturales. Elaboración propia. 2019

Jordi Borja (2014) manifiesta que las ciudades deben "facilitar la cohesión sociocultural de las comunidades", impulsando a la integración de los habitantes y la generación de una identidad colectiva. Puede interpretarse, entonces, que en este punto resulta fundamental contar con espacios físicos para el desarrollo y expresión de actividades culturales y, en igual medida, para consolidar las diversidades de los habitantes, favoreciendo la integración de la población.

En el caso de análisis, pudo observarse que existen espacios para el desarrollo de actividades culturales - pese a que no se identificó la presencia de otras dotaciones culturales recreativas como teatros, cines y/o salas audiovisuales-; e incluso que hay diversidad de expresiones culturales con significación para la comunidad. Sin embargo, en términos de la organización interna del área urbana, la cobertura de los espacios culturales resulta insuficiente para los habitantes y dificulta la integración de la comunidad.

\section{B | Análisis cualitativo del Indicador}

Las consultas en relación a los centros culturales resultaron un factor indicativo de la importancia que los habitantes de Punta Lara otorgan a la vida cultural y las actividades que se desarrollan en comunidad.

En esta línea, pudo reconocerse que los encuestados valoran las actividades gratuitas que se llevan a cabo, principalmente en el borde costero y en el Complejo Eva Perón, que les permite acceder a eventos y espectáculos a los que de otra manera no podrían acceder. En general, la población de menores recursos manifestó mayor conformidad con este tipo de actividades e indicaron como deseable poder 
seguir accediendo a las mismas e, incluso, poder contar con otro tipo de actividades y/o mayores frecuencias sin necesidad de tener que trasladarse, por ejemplo, a la localidad de Ensenada.

Abundando en la opinión, el 41\% de los encuestados reconoció que estos centros son "buenos", con actividades interesantes e instalaciones que, en general, se encuentran en buenas condiciones. En esta línea -siempre tomando en consideración el conocimiento propio de los encuestados sobre los centros culturales-, un 13\% los consideró como "regulares" y sólo un 5\% indicó como "malos", debido a que no se desarrollan suficientes actividades o las instalaciones no presentan condiciones adecuadas, entre otras cuestiones (Figura 41).

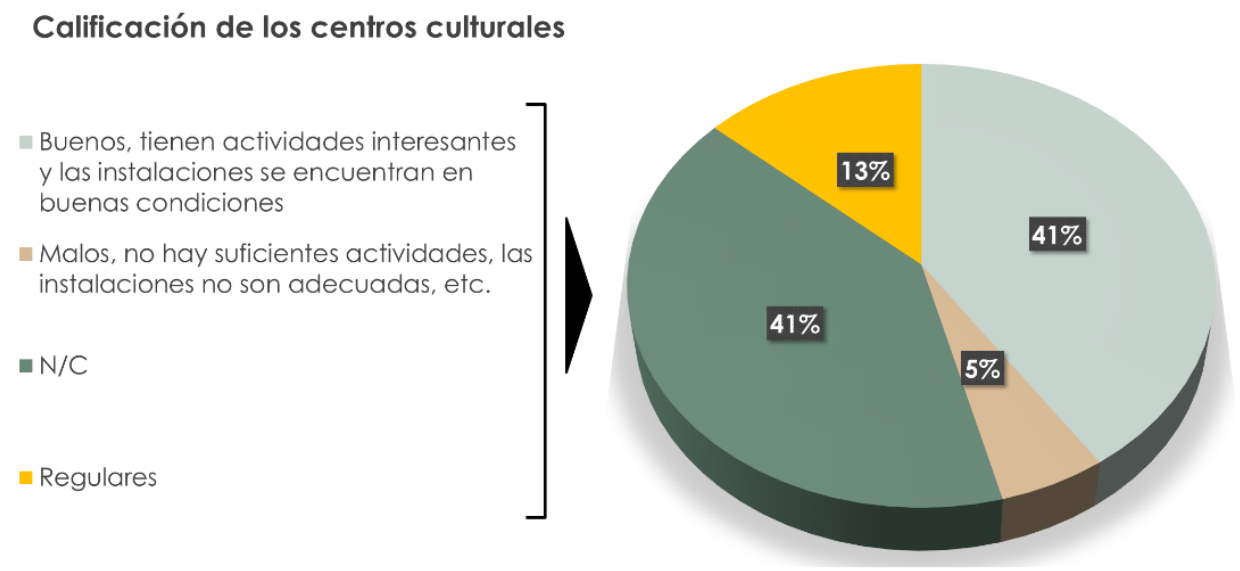

Figura 41. Resultados encuesta: Calificación centros culturales. Elaboración propia, 2019

Debido a esto -y pese a la valoración que realizan-, un 62\% de los encuestados manifestó no concurrir a centros culturales propios de la localidad de Punta Lara sino que, en general, se trasladan a Ensenada debido a que hay mayor oferta de actividades y las instalaciones revisten mejores condiciones (Figura 42).

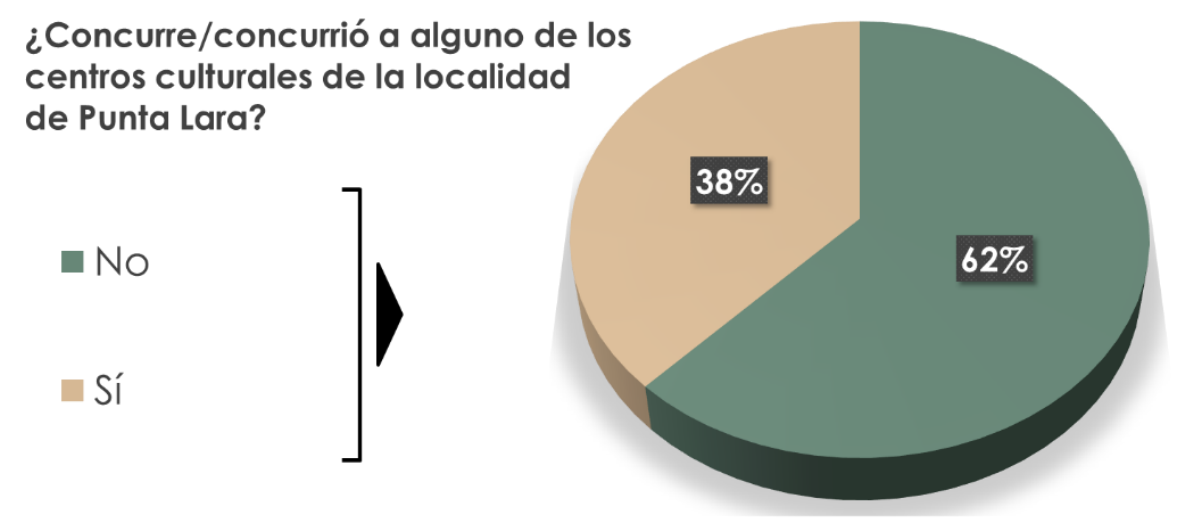

Figura 42. Resultados encuesta: Concurrencia a centros culturales. Elaboración propia, 2019

Así, al ser consultados acerca de los centros culturales a los que se acercan se reconocieron los siguientes: 


\section{Centros Culturales identificados}

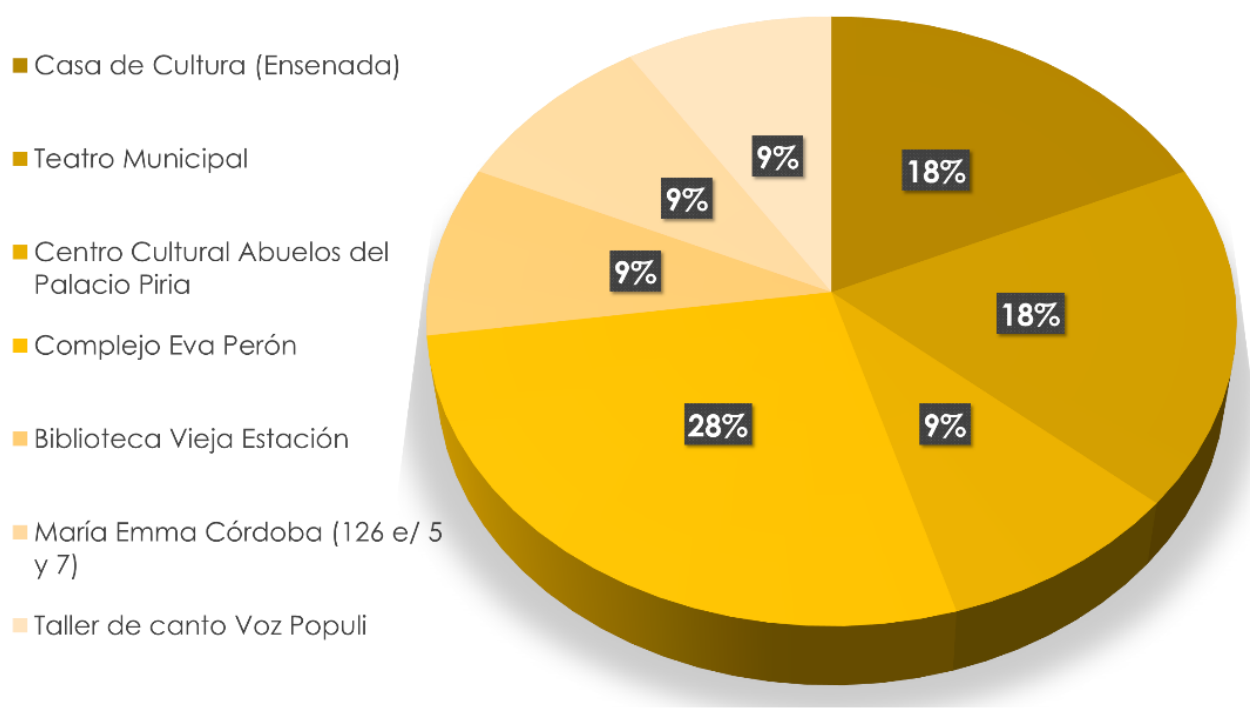

Figura 43. Resultados encuesta: Centros Culturales identificados. Elaboración propia, 2019

En relación a los aspectos identitarios con los que la población describe a la localidad, se les solicitó a los encuestados que reconocieran dos o tres lugares que consideraran representativos de Punta Lara, a partir de los cuales pudieran retratarla. En este punto, la población reconoció mayor cantidad de espacios que aquellos que fueran identificados como parte del estudio cuantitativo, enriqueciendo este aspecto de análisis del indicador (Figura 44).

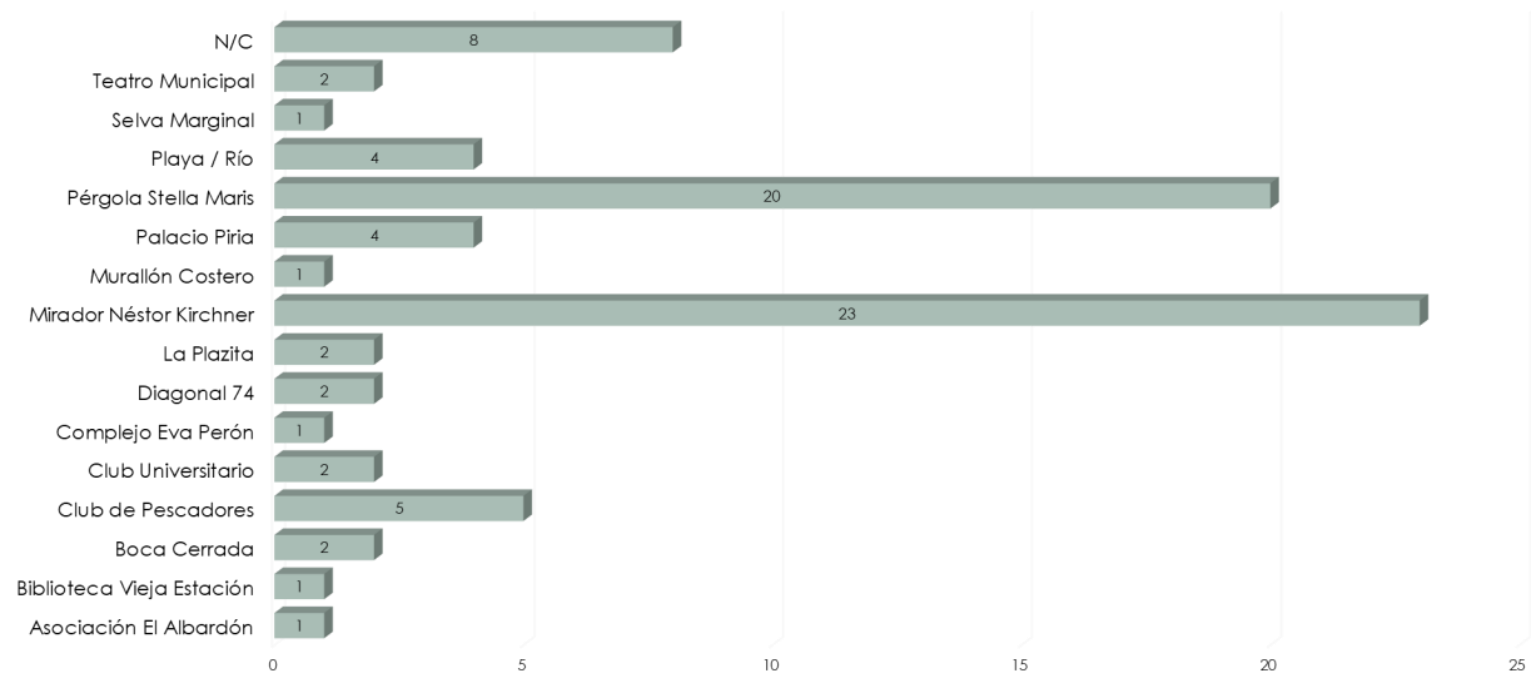

Figura 44. Resultados encuesta: Hitos/Monumentos/Espacios de significancia cultural identificados por encuestados. Elaboración propia, 2019

En general, los hitos o espacios de significación cultural que generan mayor representación para los encuestados -y que ellos mismos identificaron como aquellos que describen a la localidad-, fueron El Mirador Néstor Kirchner, la Pérgola Stella Maris y la playa/río, como par intrínseco.

Este análisis permite reflexionar acerca de la impronta que genera el contexto y el entorno territorial que caracteriza a la localidad -enfocados en la articulación entre el hombre, el espacio y el territorio, y las transformaciones que uno genera sobre el otro-; observando que la población identifica como "representativos" a lugares asociados al río y las imágenes que este genera sobre el imaginario colectivo. 
Más aún, esta impronta que puede verse claramente representada en el análisis de este indicador, se observa también en el estudio de otros indicadores, en los que la zona del río y el borde costero empiezan a actuar como concentradores de espacios, actividades y equipamientos; dinámicas que se remontan a los orígenes mismos de la urbanización de la localidad.

\section{C| Síntesis del Indicador}

A modo de reflexión general, pudo observarse que, pese a que el análisis cuantitativo dio cuenta de la insuficiencia de establecimientos para el desarrollo de actividades culturales (con un 62\% de habitantes que se encuentran en zonas con baja cobertura), la población valoró el acceso a cada uno de los centros culturales de la localidad (apoyados en que más del $40 \%$ de los encuestados los califica como "buenos" por una doble articulación entre los servicios que se ofrecen y la calidad de los establecimientos) así como las actividades que allí se realizan incluso en espacios exteriores que exceden el ámbito de los centros culturales.

Sin embargo, como empezara a inferirse a partir del análisis cuantitativo, la cantidad limitada de centros culturales en la localidad deriva en que más del $60 \%$ de la población se traslade para satisfacer estas necesidades a centros culturales por fuera del área de estudio que, en ocasiones, presentan una mayor cantidad de actividades y frecuencias, particularmente en la localidad de Ensenada. Esto pudo observarse aún más, a partir de las indagaciones en las que se solicitó a los encuestados indicar el nombre de los centros culturales a los que se dirigían.

En esta línea, un 18\% de la población consultada indicó acercarse a Casa de Cultura (Ensenada) y un 18\% al Teatro Municipal (también localizado en Ensenada). Sin embargo, de los centros localizados en la localidad de Punta Lara, el indicado en mayor cantidad de oportunidades es el Complejo Eva Perón, transformándose este último en un centro receptor de gran cantidad de población y, en consecuencia, referente para la localidad.

En síntesis, a partir de la información construida y recolectada, el primero de los datos que se valora es que -como fuera reconocido en el marco teórico y los antecedentes relevados- las actividades culturales tienen una importancia relevante en el marco del derecho a la ciudad y, especialmente, para los ciudadanos de la localidad de Punta Lara. Más aún, que la población puede alcanzar un grado de satisfacción moderado de las necesidades en torno a los derechos que aquí se analizan (como son el derecho a participar en la vida cultural y a la libre expresión de las manifestaciones culturales y el derecho a espacios seguros donde desarrollar actividades individuales y colectivas) en la localidad estudiada, pese a que, en ocasiones (apoyados en que resultan, por momentos, insuficientes los centros existentes o las actividades que se desarrollan), prefieren trasladarse a otros centros por fuera de la localidad que brindan mayores servicios en torno a estos aspectos. 


\section{FICHA METODOLÓGICA}

\section{descripción}

El indicador procura verificar si existen centros culturales de fomento de estas actividades, y también evaluar la existencia o no de expresiones artísticas que generen identidad al sector por su grado de significación

\section{objetivo de la medición}

La evaluación de este indicador se relaciona con el reconocimiento de que, en pos de alcanzar un pleno grado de satisfacción del derecho a la ciudad, la población debe poder participar de la vida cultural y, a tal fin, debe contar con espacios adecuados para el desarrollo de actividades de este tipo, entendiendo a la cultura como una actividad más para la sociedad y como un conjunto de normas y valores que guían muchas de las acciones humanas

\section{preguntas conductoras}

¿Hay centros para el desarrollo / fomento de actividades culturales? ¿La población hace uso de los mismos? ¿Hay murales que se enfoquen en la identidad del barrio? ¿Existen expresiones artísticas en el sector? ¿Se observan espacios de relevancia arquitectónica?

\section{limitaciones del indicador}

El análisis que se realiza es a partir de técnicas cuantitativas que se interpelan mediante el uso de técnicas cualitativas que aporten la visión de actores residentes en el área de estudio

\section{modalidad de medición - tratamiento del dato}

1. Inicialmente se procurará evaluar el grado de cobertura de estos espacios, según los siguientes parámetros:

\section{CENTROS CULTURALES}

Centros Culturales

Hitos/Monumentos/Expresiones/ Edificios

áreas de cobertura ("buffer")
$\begin{array}{lcc}\text { ФA } & \Phi B & \Phi C \\ 600 \mathrm{~m} & 800 \mathrm{~m} & >800 \mathrm{~m}\end{array}$

Significación para el tołal de la localidad

2. Con estos parámetros se elaborará el mapa y luego se definirá la cantidad de población que se encuentra dentro del área de cobertura, reconociendo diferentes tipos de situaciones de acuerdo a lo siguiente:

\begin{tabular}{|c|c|c|c|}
\hline \multirow[t]{2}{*}{ PCobCcult = } & hab. & \multicolumn{2}{|c|}{$\begin{array}{l}\text { PCobCcult = Población total con diferentes } \\
\text { tipos de Cobertura de Centros Culturales }\end{array}$} \\
\hline & $\Phi$ de cobertura & hab. & = Habitantes \\
\hline
\end{tabular}

3. Se interpelarán los resultados obtenidos a partir de la percepción de población residente en el área de estudio, mediante el desarrollo de encuestas

\section{escala de medición}

El indicador "centros culturales" se analizará en la escala MICRO (análisis por manzana)

\section{fuentes de información}

Visualizadores: OpenStreet Map / Street View Análisis de Imagenes Satelitales: Google Earth Normativas Municipales

Encuestas: Población residente en el área de estudio

variable dimensión factibilidad de análisis del indicador

\section{CIUDAD INCLUYENTE RECREACIÓN ALTA}

Figura 45. Ficha metodológica análisis indicador "Centros Culturales". Elaboración propia. 2019 


\subsection{3 | Dimensión EDUCACIÓN}

Para el análisis de esta dimensión se desarrolló un indicador de "Centros Educativos" que evalúa la expresión territorial de estos espacios destinados a la educación de la población, reconociendo además sus características principales.

\subsubsection{Indicador de CENTROS EDUCATIVOS}

La decisión de analizar este indicador, recae en que resulta fundamental garantizar la formación educativa para la población y el acceso a espacios que permitan este desarrollo, preparando a los ciudadanos para una plena inserción en sociedad y el desempeño de actividades fundamentales para la vida.

Se plantearon como preguntas conductoras del análisis las siguientes: ¿Existen centros educativos públicos en el sector? ¿De qué tipo (primaria, secundaria, jardín de infantes)? ¿Los estudiantes que concurren a los establecimientos proceden del sector de análisis? ¿O la población concurre a establecimientos educativos por fuera del área?

\section{A Análisis cuantitativo del Indicador}

Con esto presente, se identificaron los establecimientos educativos localizados en el área de estudio, pudiendo reconocerse tres centros correspondientes a diferentes niveles (inicial, primario, secundario). En relación al nivel inicial, se registró el jardín de Infantes №905 "Manuel Belgrano", localizado sobre la Avenida Almirante Brown que, además de la educación inicial, ofrece el servicio de jardín maternal. De acuerdo a los datos de la Dirección Provincial de Planeamiento (Mapa Escolar, 2018) ${ }^{21}$, cuenta con 389 alumnos y provee, como parte del Servicio Alimentario Escolar, servicios de comedor simple, desayuno y merienda completa.

La escuela primaria №6 "Hernando Arias de Saavedra" y secundaria №2 "Santiago de Liniers", también se encuentran localizadas sobre la Avenida Almirante Brown (Mapa 11). La primera cuenta con 544 alumnos en dos turnos de funcionamiento (mañana y tarde), y, al igual que el Jardín de Infantes №905 provee el servicio de comedor, desayuno y merienda a la matrícula. La Secundaria №2 reúne a un total de 424 alumnos, también con doble turno de funcionamiento, pero sin proveer servicios alimentarios.

El hecho de que estos establecimientos ofrezcan servicios alimentarios permite inferir una primera conclusión asociada a que, al menos una parte de la población que asiste presenta una carencia en este sentido y, por ende, las instituciones intentan dar respuesta a esa necesidad con el objeto de suplir un derecho básico como es el de la alimentación.

Todos estos establecimientos se encuentran clasificados con una condición de "Desfavorabilidad U1", que refiere a que "Tanto la ubicación como las dificultades de acceso generan condiciones de trabajo diferenciales para los docentes, por ello reciben una bonificación..." (Dirección Provincial de Planeamiento, Dirección de Información y Estadística, 2018), que en este caso es del 30\%.22

\footnotetext{
${ }^{21}$ DGCyE, Dirección Provincial de Planeamiento, Dirección de Información y Estadística. Relevamiento Inicial 2018. Disponible en: http://mapaescolar.abc.gob.ar/mapaescolar/

${ }^{22}$ Desfavorabilidad: Es una de las clasificaciones de los establecimientos de enseñanza en función de su ubicación y/o dificultades de acceso. Tanto la ubicación como las dificultades de acceso generan condiciones de trabajo diferenciales para los docentes, por ello reciben una bonificación según la siguiente escala: Normal, 0\%; Desfavorable I, 30\%; Desfavorable II, 60\%; Desfavorable III, $90 \%$; Desfavorable IV, 100\%; Desfavorable V, $120 \%$
} 

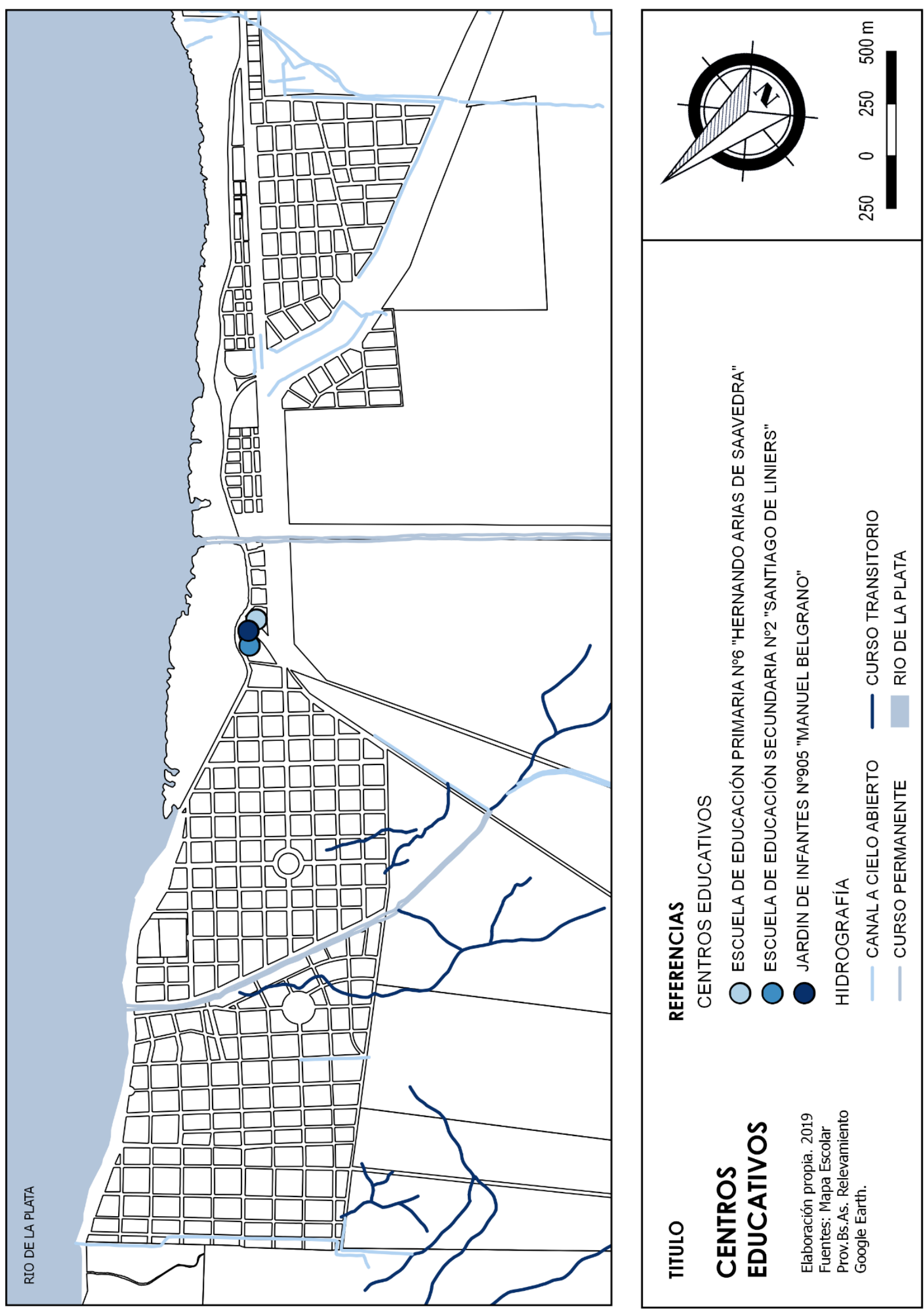

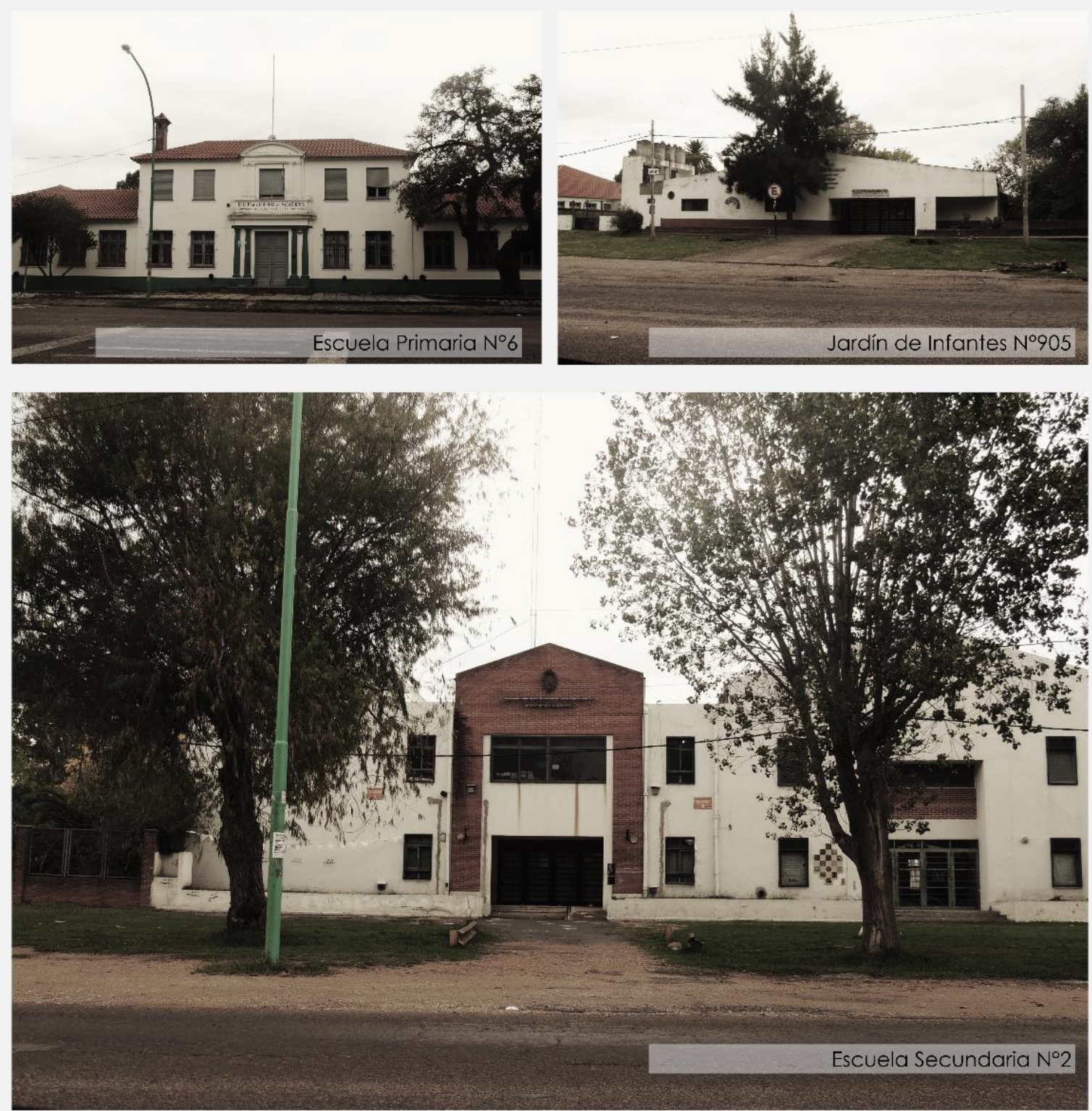

Figura 46. Fotos Centros Educativos. Fotografías Arq. Estefanía Jáuregui. 2018

Para el análisis de este indicador, se interpretó que, para considerarse una cobertura adecuada, los niveles iniciales y primarios debían localizarse a una distancia no mayor a 300 metros; mientras que el nivel secundario tendría mayor radio de cobertura, tomándose como distancia óptima los 600 metros.

\section{CENTROS EDUCATIVOS}

Nivel Inicial

Nivel Primario

Nivel Secundario

\section{áreas de cobertura ("buffer")}

$\begin{array}{ccc}\Phi A & \Phi B & \Phi C \\ 300 \mathrm{~m} & 600 \mathrm{~m} & >600 \mathrm{~m} \\ 300 \mathrm{~m} & 600 \mathrm{~m} & >600 \mathrm{~m} \\ 600 \mathrm{~m} & 800 \mathrm{~m} & >800 \mathrm{~m}\end{array}$

Con estos parámetros y los establecimientos localizados, se construyó el Mapa 12 en colores gradientes de rojo, demostrando una concentración de estos establecimientos en el área central y, por ende, de la cobertura de los mismos. Un aspecto a destacar es que los centros educativos se encuentran en áreas con acceso a infraestructura de servicios básica, lo cual permite un desarrollo más eficiente de sus actividades y una mejora de las prestaciones -debido a que incluso hay centros que ofrecen el servicio de comedor a la matrícula-. 

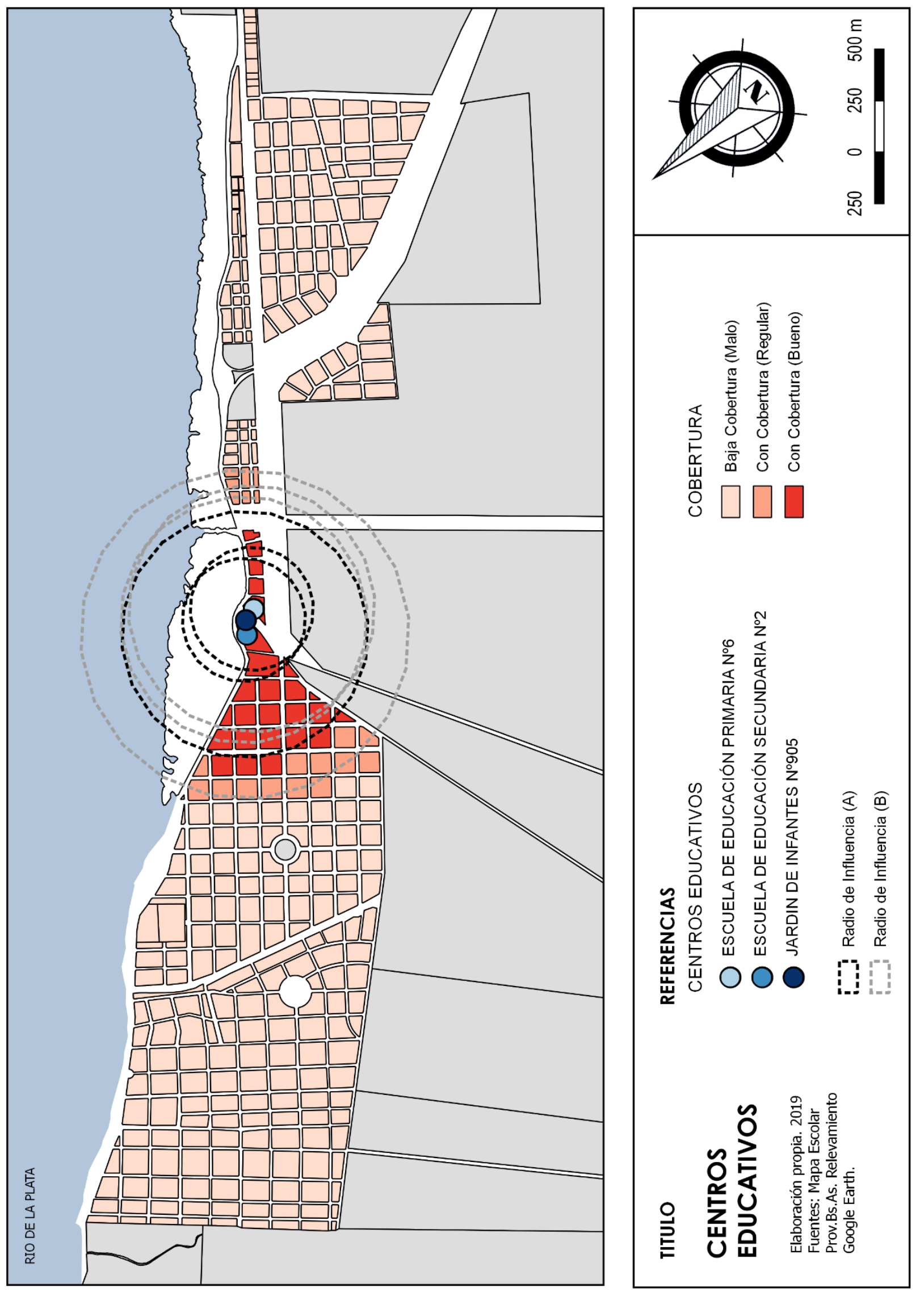
A partir de este mapa, el cómputo de la cantidad de población que se encontraba dentro del área de cobertura se desarrolló a partir de la fórmula que fuera aplicada en el análisis de los indicadores previos (Figura 47)

\section{PCobCeduc $=$ hab. $\Phi$ de cobertura}

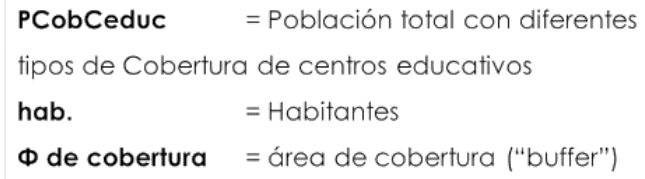

Figura 47. Modalidad de medición de análisis de población en área de cobertura Centros Educativos. Elaboración propia. 2019

El recuento de la población contenida en cada una de las zonas, condujo a la identificación de que la concentración de los centros educativos es llamativamente más evidente que en el análisis de otros indicadores, observándose que el $84 \%$ de la población no se encuentra dentro de ninguno de los radios de cobertura (Bueno ni Regular) -un total de 9604 habitantes-, mientras que sólo un 9\% tiene una cobertura buena de estos centros y un 7\% cuenta con una cobertura regular -sumando un total de 1801 habitantes- (Figura 48).

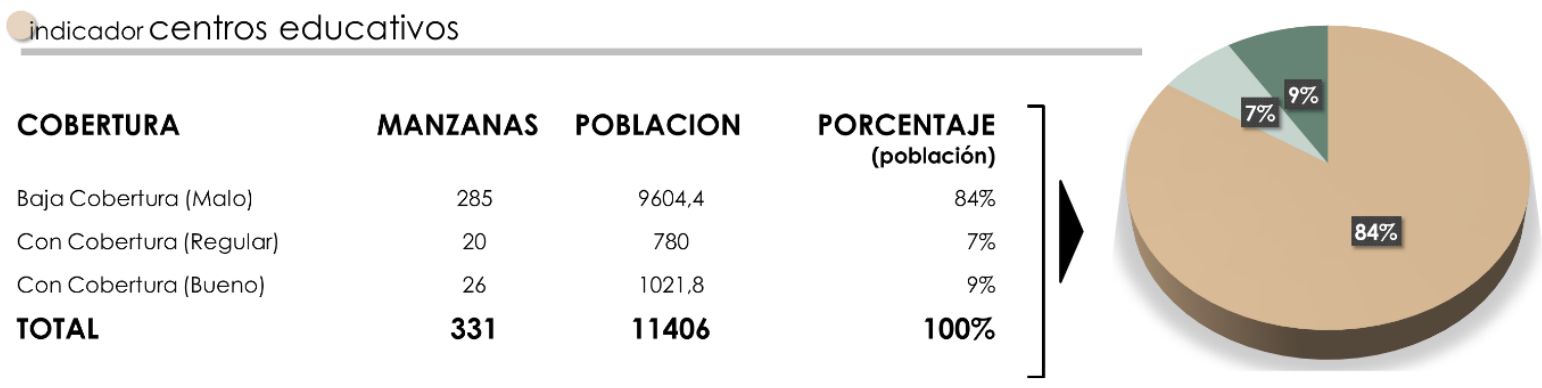

Figura 48. Análisis de la cobertura de centros educativos. Elaboración propia. 2019

A modo de conclusión, pudo observarse nuevamente una concentración del área de cobertura en el área central del recorte, situación que genera que la población deba desplazarse grandes distancias para acceder a los centros educativos.

\section{B Análisis cualitativo del Indicador}

La indagación cualitativa en torno a los centros educativos se enfocó en el acceso real de la población a la educación pública y gratuita en establecimientos cercanos a su lugar de residencia. En esta línea, se consultó a cada uno de los encuestados si ellos -o alguien de su familia- concurren o concurrieron a establecimientos educativos en la localidad de Punta Lara.

Las primeras apreciaciones en torno a esta consulta indicaban que la población en general se trasladaba a centros educativos por fuera de la localidad. Sin embargo, el procesamiento de las encuestas y el volcamiento de los datos demostraron que las respuestas se encontraban divididas en porcentajes relativamente similares, con un $57 \%$ de los encuestados o familiares que concurrieron a establecimientos en la localidad y un $43 \%$ que dieron respuestas negativas (Figura 49). 


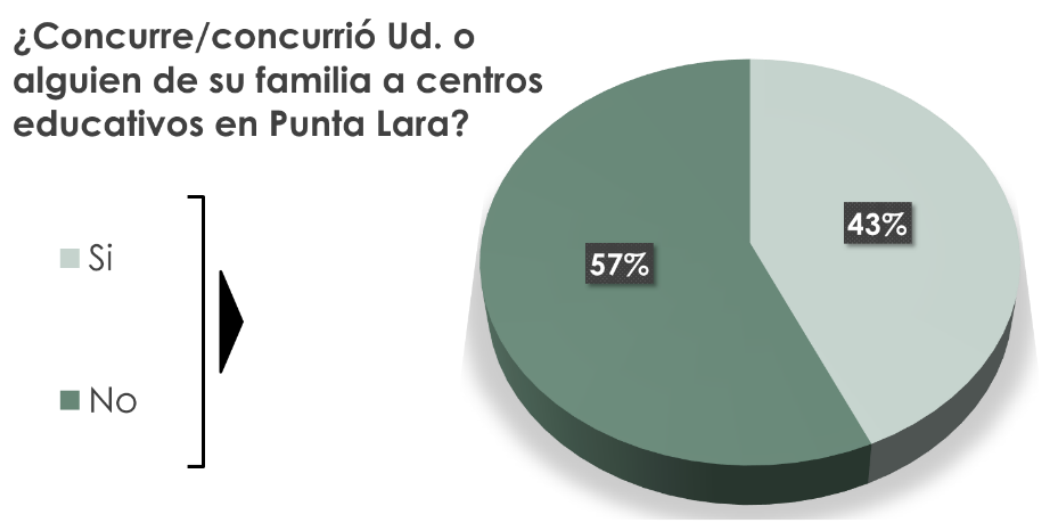

Figura 49. Resultados encuesta: Concurrencia a Centros Educativos. Elaboración propia, 2019

En relación a esto, quienes indicaron respuestas afirmativas, señalaron aquellos establecimientos identificados como parte del análisis en el Mapa 11: el jardín de Infantes º505 "Manuel Belgrano", la escuela primaria №6 "Hernando Arias de Saavedra" y la secundaria №2 "Santiago de Liniers", todos sobre la Avenida Almirante Brown. Quienes se trasladan o trasladaron, lo hacen a establecimientos fuera de la localidad de Punta Lara y, en general, se movilizan hasta el centro de Ensenada en donde la oferta de establecimientos educativos públicos es mayor.

Adoptando estas cuestiones como referencia, la siguiente consulta refería a la consideración de los encuestados acerca de si estos centros educativos resultaban suficientes para abastecer las necesidades $y$, por ende, la demanda en Punta Lara. En este sentido, un porcentaje muy elevado de los encuestados (70\%) consideró que es insuficiente la oferta existente motivo por el cual suelen trasladarse a otros establecimientos educativos de la región. Sólo un 30\% de los encuestados respondió afirmativamente, indicando que estas instituciones dan respuesta a las necesidades de los habitantes de Punta Lara (Figura $50)$.

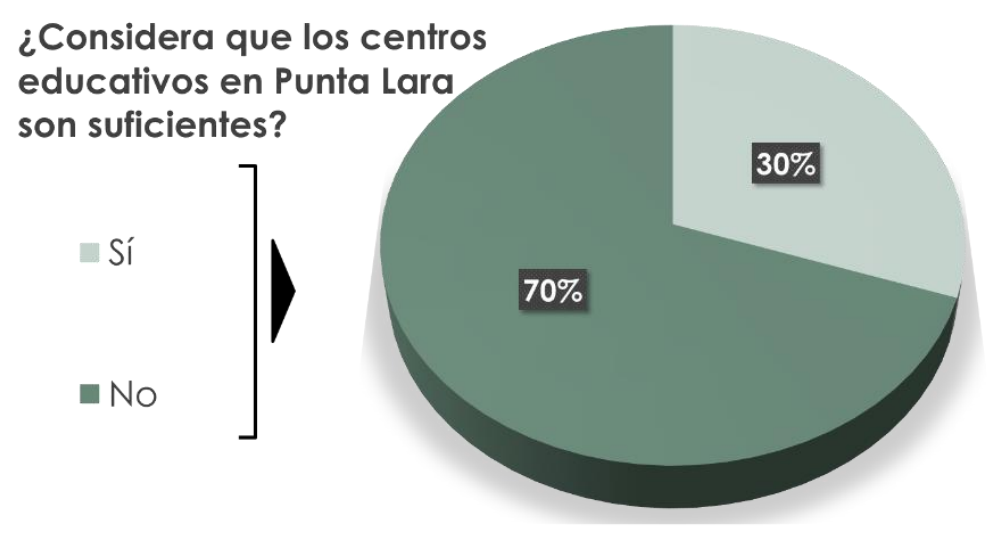

Figura 50. Resultados encuesta: Suficiencia/Insuficiencia de Centros Educativos. Elaboración propia, 2019

Otro de los interrogantes en relación a este indicador se enfocaba en la calidad de estos centros educativos, principalmente, en el sentido de las condiciones infraestructurales. El objetivo de esta consulta fue dialogar y permitir los comentarios de los encuestados, que en ocasiones referían al estado de las edificaciones y en otros momentos realizaban críticas, de modo general, a las modalidades de enseñanza en los establecimientos -temáticas que exceden al tema de esta tesis, pero resultaron interesantes para el análisis y la percepción de la población encuestada-. 
En este sentido, más del 39\% de los encuestados calificó estos centros como "regulares" y un 26\% indicó que los consideraban "buenos", en general, en coincidencia con aquellos que concurren o concurrieron a alguno de los establecimientos de la localidad. Sólo un $11 \%$ de los encuestados indicó que consideraba como "malos" a los establecimientos educativos, fundamentando estas respuestas en el estado de las instalaciones e infraestructuras de las escuelas de la localidad, remitiendo a la falta de mantenimiento de los establecimientos, o la calidad de la educación que hace que, en ocasión de elegir, se inclinen por otros centros educativos, dentro de las posibilidades a las que cada uno puede acceder (Figura 51).

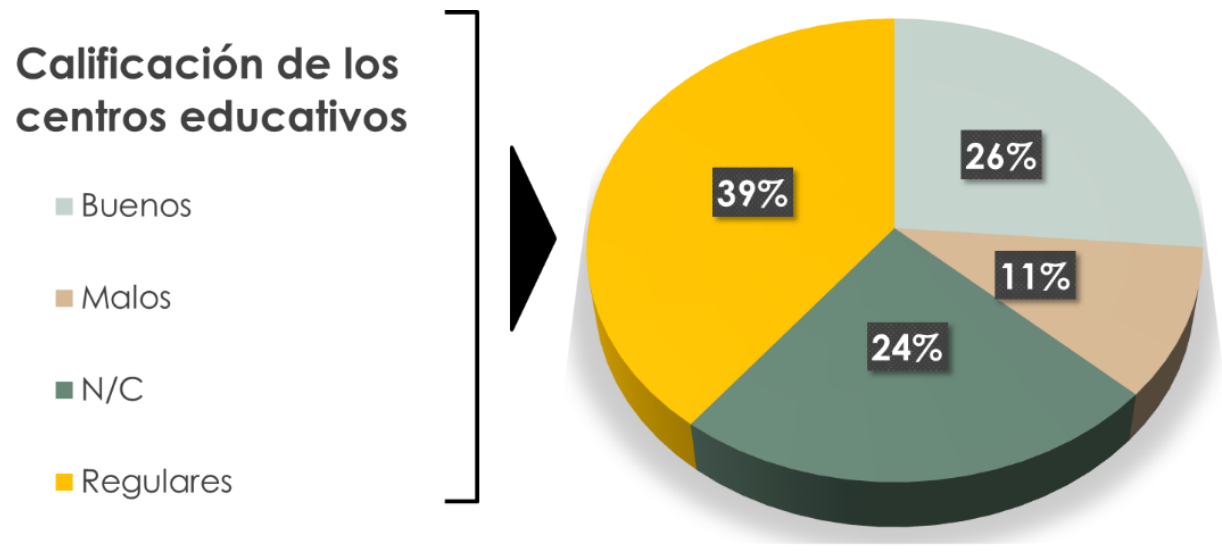

Figura 51. Resultados encuesta: Calificación centros educativos. Elaboración propia, 2019

\section{C| Síntesis del Indicador}

En términos globales, la evaluación cuantitativa realizada coincide con muchas de las cuestiones manifestadas por la población encuestada, principalmente en lo que refiere a la suficiencia/insuficiencia de los establecimientos educativos para satisfacer las necesidades de los habitantes de la localidad (en términos de la cantidad de oferta de establecimientos que permitan el acceso a la educación).

En esta línea, la consideración por parte de la población de los centros educativos da cuenta de que estos se encuentran en condiciones no adecuadas, en ocasiones, para dar respuesta a las necesidades. Estos escenarios generan que mucha de la población se traslade a centros educativos por fuera de Punta Lara; poniendo de manifiesto, además, aspectos asociados al contexto de la localidad, que funciona como un enclave independiente de características particulares, pero mantiene estrechas relaciones con otras localidades del partido y ciudades de partidos aledaños -principalmente el partido de La Plata-.

Retomando el análisis referido a la satisfacción de la necesidad y el acceso a este tipo de establecimientos -asociado a las concepciones teóricas sobre las que se sustenta esta investigación-, podemos afirmar que el análisis de los contextos actuales nos permite identificar a las ciudades como espacios en constante modificación producto de procesos de globalización y un sistema económico neoliberal predominante; situación que hace que resulte fundamental formar a los individuos en valores, herramientas y conceptos que permitan abordar los requerimientos y problemáticas de estas ciudades en constante modificación.

De esta manera, si se considera que los centros educativos son los espacios de formación de ciudadanos, que nos permiten adquirir valores y herramientas e impulsan a la ciudadanía en el reclamo por la concreción de derechos -incluido el derecho a la ciudad-, los valores y parámetros reconocidos en el área de estudio deben ser analizados con una mirada crítica y tendiente a la mejora en la cobertura que estos centros educativos representan en el territorio y la percepción de la población en relación a los mismos. 
FICHA METODOLÓGICA

\section{descripción}

El indicador busca verificar la existencia de centros educativos en el sector y las características de estos

\section{objetivo de la medición}

El indicador se analiza ya que resulta fundamental garantizar la formación educativa para la población y el acceso a espacios que permitan el desarrollo de esta formación, preparando a los ciudadanos para una plena inserción en sociedad y el desempeño de actividades fundamentales para el desarrollo

\section{preguntas conductoras}

¿Existen centros educativos públicos en el sector? ¿De qué tipo? ¿Los estudiantes que concurren a los establecimientos proceden del sector de análisis? ¿o la población concurre a establecimientos educativos por fuera del sector de análisis?

\section{limitaciones del indicador}

El análisis que se realiza es a partir de técnicas cuantitativas que se interpelan mediante el uso de técnicas cualitativas que aporten la visión de actores residentes en el área de estudio

\section{modalidad de medición - tratamiento del dato}

1. Inicialmente se procurará evaluar el grado de cobertura de estos espacios, según los siguientes parámetros:

\section{CENTROS EDUCATIVOS}

Nivel Inicial

Nivel Primario

Nivel Secundario áreas de cobertura ("buffer")

$\Phi \mathrm{A}$

(gestión estatal)
(gestión estatal)
(gestión estatal)

$\begin{array}{ccc}\text { ФA } & \Phi B & \Phi C \\ 300 \mathrm{~m} & 600 \mathrm{~m} & >600 \mathrm{~m} \\ 300 \mathrm{~m} & 600 \mathrm{~m} & >600 \mathrm{~m} \\ 600 \mathrm{~m} & 800 \mathrm{~m} & >800 \mathrm{~m}\end{array}$

2. Con estos parámetros se elaborará el mapa y luego se definirá la cantidad de población que se encuentra dentro del área de cobertura, reconociendo diferentes tipos de situaciones de acuerdo a lo siguiente:

\begin{tabular}{|c|c|c|c|}
\hline \multirow[t]{2}{*}{ PCobCeduc = } & \multirow{2}{*}{$\frac{\text { hab. }}{\Phi \text { de cobertura }}$} & \multicolumn{2}{|c|}{$\begin{array}{l}\text { PCobCeduc = Población total con diferentes } \\
\text { tipos de Cobertura de centros educativos }\end{array}$} \\
\hline & & $\begin{array}{l}\text { hab. } \\
\Phi \text { de cobertura }\end{array}$ & $\begin{array}{l}=\text { Habitantes } \\
=\text { área de cobertura ("buffer") }\end{array}$ \\
\hline $\mathrm{Co}$ & ura (Bueno) $\quad \Phi B=$ Con $C$ & (Regular) & $=$ Sin Cobertura (Malo) \\
\hline
\end{tabular}

3. Se interpelarán los resultados obtenidos a partir de la percepción de población residente en el área de estudio, mediante el desarrollo de encuestas

\section{escala de medición}

El indicador "centros educativos" se analizará en la escala MICRO (análisis por manzana)

\section{fuentes de información}

Visualizadores: OpenStreet Map / Street View Análisis de Imagenes Satelitales: Google Earth Mapa Escolar

Encuestas: Población residente en el área de estudio

\section{variable}

CIUDAD INCLUYENTE dimensión factibilidad de análisis del indicador

ALTA

Figura 52. Ficha metodológica análisis indicador "Centros Educativos". Elaboración propia. 2019 


\subsubsection{Dimensión SALUD}

El análisis de la dimensión SALUD se desarrolló a partir de la construcción de un indicador de "Centros de Salud", a fin de poder estudiar el acceso de la población a este servicio básico.

\subsubsection{Indicador de CENTROS DE SALUD}

El indicador "Centros de Salud" procuró evaluar la existencia de centros de salud en el sector, que permitan la atención gratuita de la población. Su estudio resultaba relevante ya que el Estado debiera ser el encargado de que los establecimientos se encuentren al alcance geográfico de todos los sectores de la población, siendo de vital importancia en el marco del derecho a la ciudad y encontrándose reconocido, además, en diferentes instrumentos normativos.

En esta línea, la Constitución de la Nación Argentina manifiesta en su artículo 42, que "Los consumidores y usuarios de bienes y servicios tienen derecho, en la relación de consumo, a la protección de su salud, seguridad e intereses económicos; a una información adecuada y veraz; a la libertad de elección y a condiciones de trato equitativo y digno", manifestando que las autoridades deberán proteger esos derechos y garantizar la eficiencia de este servicio público.

Más aún, la Declaración Universal de Derechos Humanos, a la cual el Estado argentino adhiere, proclama en el artículo $75^{\circ}$ que "Toda persona tiene derecho a un nivel de vida adecuado que le asegure, así como a su familia, la salud y el bienestar, y en especial la alimentación, el vestido, la vivienda, la asistencia médica y los servicios sociales necesarios...".

En esta línea, las preguntas conductoras para el estudio del indicador fueron: ¿Existen centros de salud gratuitos, para la atención de la población? ¿Pueden estos centros abastecer a toda la población? ¿Se encuentran en cercanías de las diferentes áreas urbanas?

\section{A | Análisis cuantitativo del Indicador}

Inicialmente, se procedió a identificar los centros de salud (Figura 53) así como los servicios que estos ofrecen. En relación a esto, pudo reconocerse que los servicios que se proveen están asociados a clínica médica -fundamentalmente-, a la obstetricia, nutrición, odontología y, en algunos casos, psicología. Con esta información, se construyó el Mapa 13.

\begin{tabular}{lcr} 
Centros de Salud & Localización & Servicios que proveen \\
\hline Unidad Sanitaria N N184 & Camino Costanero Almirante Brown. Columna 184 & Clínica Médica; Pediatría; Obstetricia; \\
Unidad Sanitaria N N298 & Camino Costanero Almirante Brown. Columna 298 & Clínica Médica; Pediatría; Obstetricia; \\
Unidad Sanitaria Complejo & Camino Costanero Almirante Brown y calle 60 & Nutrición; Odontología \\
Eva Perón & Camino Costanero Almirante Brown e/ calle 70 y \\
Unidad Sanitaria & Rotonda
\end{tabular}

Figura 53. Identificación de Centros de Salud. Elaboración propia. Fuente: https://www.ensenada.gov.ar/552/ 

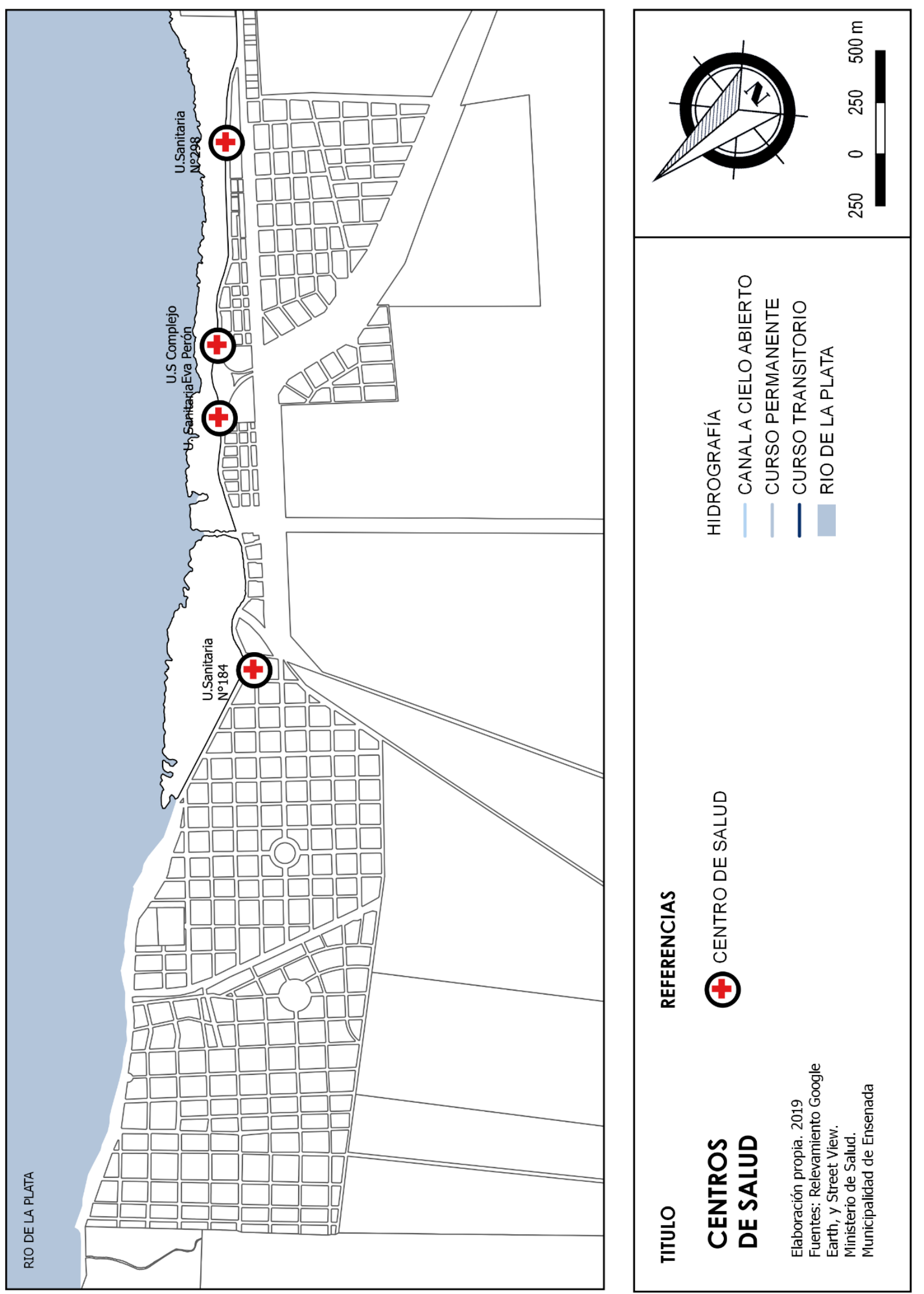
Para este caso, se identificó en principio la ausencia de centros de salud de gran envergadura (hospitales). Los centros existentes constituyen "Unidades Sanitarias" de menor consideración y con una cobertura en términos de salud más limitada. En el cálculo de este indicador se adoptaron los 600 metros como radio de cobertura bueno, mientras que la cobertura regular se consideró como aquella contenida en un radio de 800 metros y a mayor distancia se consideró una ausencia de cobertura.

\begin{tabular}{lccc} 
CENTROS DE SALUD & \multicolumn{3}{c}{ áreas de cobertura ("buffer") } \\
\cline { 2 - 3 } & $\Phi \mathrm{A}$ & $\Phi B$ & $\Phi \mathrm{C}$ \\
\hline Unidades Sanitarias & $600 \mathrm{~m}$ & $800 \mathrm{~m}$ & $>800 \mathrm{~m}$
\end{tabular}

Con estos parámetros y los establecimientos localizados, se construyó el Mapa 14 que permitió reconocer que los centros de salud se encuentran sobre el área del borde costero y que existen barrios con una cobertura muy limitada (por ej. El Barrio Punta Lara casco), particularmente sobre el área oeste en las cercanías de la zona de la Reserva Natural, un área que, como pudo observarse en el análisis del proceso de ocupación, ha presentado un crecimiento importante en los últimos años. 

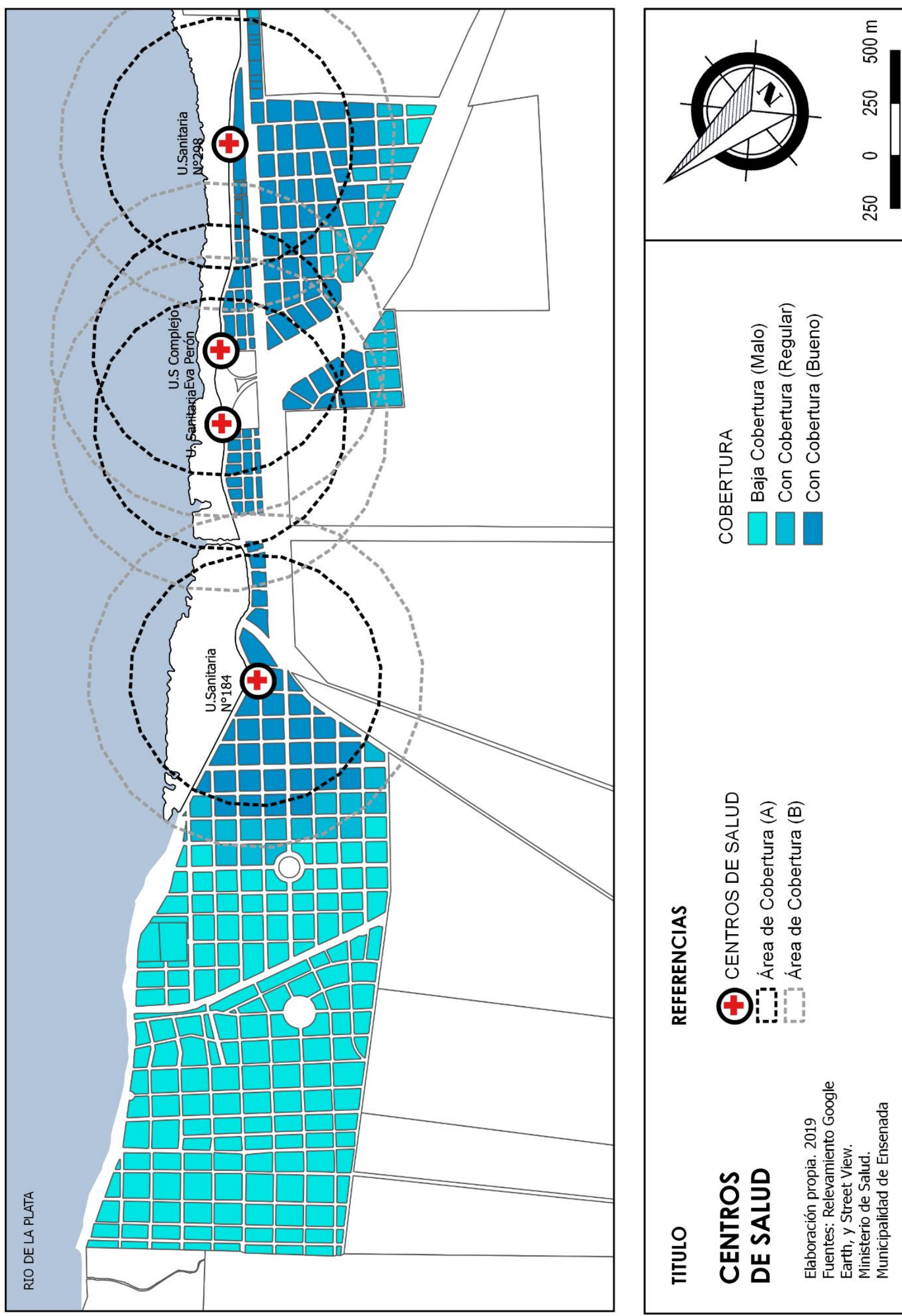
El estudio de la población que se encuentra dentro de cada uno de los radios permitió reconocer un porcentaje elevado de población con cobertura adecuada de este indicador.

\section{PCobCsalud = \\ hab. \\ $\Phi$ de cobertura}

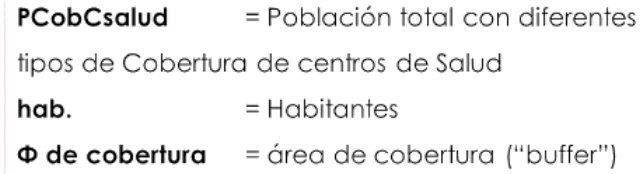

Figura 54. Modalidad de medición de análisis de población en área de cobertura Centros de Salud. Elaboración propia. 2019

Si consideramos la cobertura buena y regular, puede interpretarse que hay un $66 \%$ de población dentro de estos parámetros -un $42 \%$ de población en un radio de cobertura bueno y un $14 \%$ con una cobertura regular-. Sin embargo, el indicador ha mostrado un porcentaje elevado de población con baja cobertura de estos centros de salud -un 44\% de la población-, reflejadas en un total de 5051 habitantes (Figura 55).

indicador centros de salud

\section{COBERTURA}

Baja Cobertura (Malo)

Con Cobertura (Regular)

Con Cobertura (Bueno)

TOTAL
MANZANAS

$\begin{array}{cc}161 & 5051,8 \\ 38 & 1575,6 \\ 132 & 4778,8 \\ 331 & 11406\end{array}$
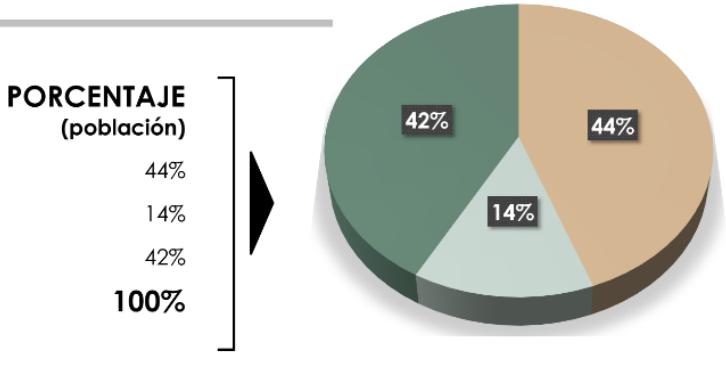

Figura 55. Análisis de la cobertura de centros de salud. Elaboración propia. 2019

Es decir que un porcentaje muy cercano a la mitad de la población del área de estudio no tiene un acceso pleno a un espacio de prestación de un servicio básico como es el de salud, debiendo acercarse a centros que se encuentran alejados de sus barrios.

Más aún, si consideramos que se trata de centros de salud representados por "Unidades Sanitarias", en caso de emergencias que requieran una atención de mayor complejidad, el área de estudio no cuenta con centros adecuados para este tipo de prestación y los ciudadanos deben trasladarse a otra localidad.

\section{B | Análisis cualitativo del Indicador}

En pos de interpelar los datos cuantitativos obtenidos, se consultó a la población si, en caso de tener que recibir atención médica, lo hacía en los centros de la localidad de Punta Lara. Las respuestas dieron cuenta de que, en caso de tener elección, sólo un $22 \%$ de los encuestados se acerca a los centros locales para recibir atención médica; mientras que el $78 \%$ de los encuestados prefiere trasladarse a centros de salud por fuera de la localidad de Punta Lara (Figura 56).

Estos datos refuerzan el análisis cuantitativo que daba cuenta de que, pese a que un porcentaje elevado de población poseía "cobertura" por la cercanía a centros de atención de salud (aproximadamente un $66 \%$ de la población presentaba cobertura entre buena y regular), las condiciones de estas unidades (en términos de capacidad de atención, servicios que facilitan, calidad de las instalaciones, entre otros) generan que gran cantidad de población se traslade a otros centros. 


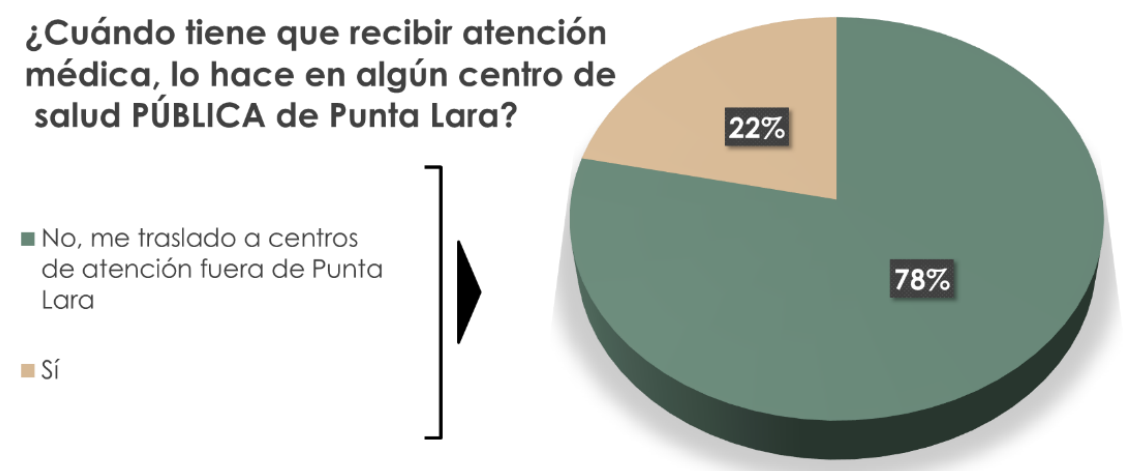

Figura 56. Resultados encuesta: Atención médica en centros de salud. Elaboración propia, 2019

Abundando en esta temática, con el objeto de inferir el motivo de estos traslados, se indagó acerca del conocimiento popular que tenían de estos centros, a fin de poder dar cuenta de la percepción de los habitantes de las condiciones en las que se encuentran, los servicios que prestan, entre otras cuestiones. En este punto, resultó llamativo que, pese a que gran parte de la población se desplaza a centros de salud fuera de la localidad, el conocimiento popular que poseen de estos establecimientos -o eventuales atenciones menores en estos centros- conduce a que el $54 \%$ de los encuestados los califique como "buenos" ("me atendieron muy bien") y un $24 \%$ como "regulares" ("se podrían mejorar las instalaciones, o brindar más servicios", "no hay guardias médicas"). Solo un 11\% de los encuestados los califica rotundamente como "malos" y consideran que siempre deben trasladarse para satisfacer las necesidades de salud (Figura 57).

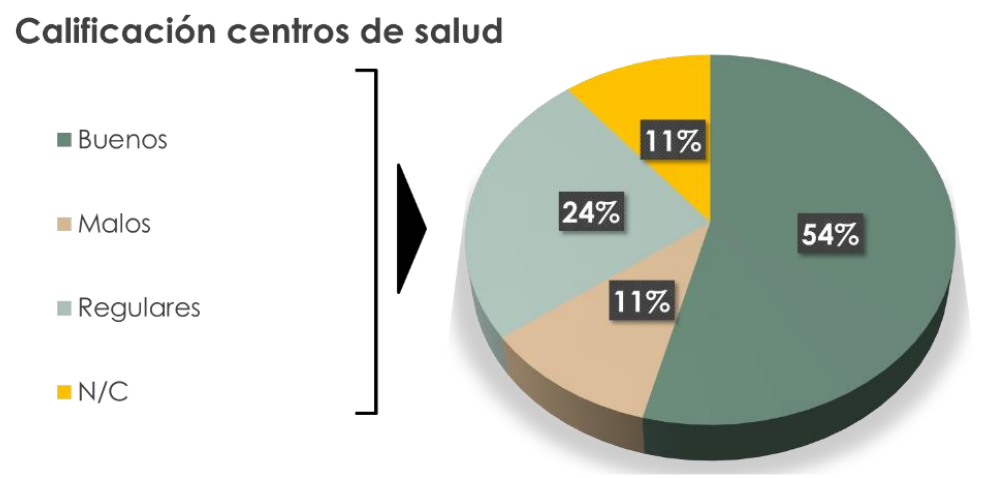

Figura 57. Resultados encuesta: Calificación centros de salud. Elaboración propia, 2019

\section{C| Síntesis del Indicador}

Como síntesis de este indicador, pudo observarse que al consultarse a la población acerca de la localización de los centros de salud a los que se dirigen en caso de tener que recibir atención médica, la mayor parte de ellos indicó como punto de referencia al Hospital Cestino, valorando la calidad de la atención y los servicios a los que allí pueden acceder. Así, nuevamente se complementa el análisis desarrollado cuantitativamente, en el que se identificaron los centros de salud (Mapa 13), reconociendo la inexistencia de centros de gran envergadura (los centros existentes constituyen unidades sanitarias). Pese a esto, el conocimiento popular que la población tiene de estos establecimientos, los conduce a afirmar en ocasiones que, pese a que no reciben atención en estos centros, la calidad de los mismos puede considerarse como regular o incluso buenas.

En síntesis, puede inferirse que, a pesar de que existe un déficit en el acceso a centros de salud en la localidad, la posibilidad de contar con un servicio gratuito y de calidad en la localidad de Ensenada permite saldar ciertas necesidades de salud en una distancia relativamente corta y que los encuestados están dispuestos a recorrer. En este punto, algunos de los encuestados refirieron trasladarse a otros centros de salud, principalmente en el partido de La Plata, por elección propia y, en general, para el desarrollo de estudios específicos o una atención médica particular. 


\section{FICHA METODOLÓGICA}

\section{descripción}

El indicador procura evaluar la existencia de centros de salud en el sector, que permitan la atención gratuita de la población.

\section{objetivo de la medición}

El estudio de este indicador resulta relevante en términos de garantizar el acceso a la salud para los ciudadanos, ya que el Estado debiera procurar que los establecimientos se encuentren al alcance geográfico de todos los sectores de la población, siendo de vital importancia en el marco del derecho a la ciudad; y encontrándose, además, reconocido en diferentes instrumentos normativos

\section{preguntas conductoras}

¿Existen centros de salud gratuitos, para la atención de la población? ¿Pueden estos centros abastecer a toda la población? ¿Se encuentran en cercanías de las diferentes áreas urbanas?

\section{limitaciones del indicador}

El análisis que se realiza es a partir de técnicas cuantitativas que se interpelan mediante el uso de técnicas cualitativas que aporten la visión de actores residentes en el área de estudio

\section{modalidad de medición - tratamiento del dato}

1. Inicialmente se procurará evaluar el grado de cobertura de estos espacios, según los siguientes parámetros:

\section{CENTROS DE SALUD}

Unidades Sanitarias áreas de cobertura ("buffer")

$\begin{array}{ccc}\Phi A & \Phi B & \Phi C \\ 600 \mathrm{~m} & 800 \mathrm{~m} & >800 \mathrm{~m}\end{array}$

2. Con estos parámetros se elaborará el mapa y luego se definirá la cantidad de población que se encuentra dentro del área de cobertura, reconociendo diferentes tipos de situaciones de acuerdo a lo siguiente:

$$
\text { PCobCsalud }=\frac{\text { hab. }}{\Phi \text { de cobertura }}
$$

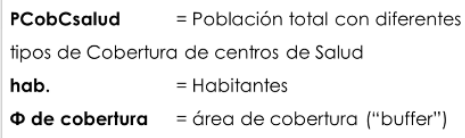

3. Se interpelarán los resultados obtenidos a partir de la percepción de población residente en el área de estudio, mediante el desarrollo de encuestas

\section{escala de medición}

El indicador "centros de salud" se analizará en la escala MICRO (análisis por manzana)

\section{fuentes de información}

Visualizadores: OpenStreet Map / Street View Análisis de Imagenes Satelitales: Google Earth Encuestas: Población residente en el área de estudio

factibilidad de análisis del indicador

$\begin{array}{lll}\text { variable } & \text { dimensión } & \text { factib } \\ \text { CIUDAD INCLUYENTE } & \text { RECREACIÓN } & \text { ALTA }\end{array}$

Figura 58. Ficha metodológica análisis indicador "Centros de Salud". Elaboración propia. 2019 


\subsection{5 | Dimensión CULTO}

Para el análisis de esta dimensión se desarrolló un indicador de "Centros Religiosos" que evaluó la expresión territorial de espacios destinados al culto.

\subsubsection{Indicador de CENTROS RELIGIOSOS}

El indicador de "Centros Religiosos" buscó aportar información en relación a la existencia de equipamientos que permitan el desarrollo de actividades religiosas y de culto, constituyendo también soportes para actividades de reunión y socialización entre los miembros de la comunidad, transformándose en espacios con una función simbólica importante en la configuración de la ciudad.

Se trata de un indicador relevante en pos de garantizar el derecho a la ciudad que se encuentra reconocido en la Constitución Nacional Argentina, específicamente en su artículo 14, que afirma que todos los habitantes de la Nación gozan de múltiples derechos, entre los que reconoce el derecho a trabajar, el derecho a exponer ideas libremente; e incluye el derecho a profesar libremente el culto, sin distinción de la orientación del mismo.

Como puede observarse, resultaba complejo pensar en un análisis de este indicador en términos de cobertura o acceso real de la población a estos establecimientos. Por ese motivo, las preguntas a las que se buscó dar respuesta a partir del análisis de este indicador estuvieron relacionadas a la existencia o no de centros religiosos en el área y, en caso de que existieran, definir si se trataban de una misma religión o si podía reconocerse una diversidad en el culto.

\section{A | Análisis cuantitativo del Indicador}

En principio entonces, se procedió a la identificación de los centros y a su localización en el espacio. Se reconocieron cuatro centros para el desarrollo de actividades de culto en el área de estudio, a partir de información de organismos oficiales (Registro Nacional de Cultos):

- Capilla Stella Maris (Centro cristiano); ubicada en calle 128, entre Camino Gral. Almirante Brown y calle 3;

- Iglesia Stella Maris (Centro cristiano), localizada en el Camino Gral. Almirante Brown, entre la calle 83 y el Arroyo Rodríguez;

- Asociación de los Testigos de Jehová; en calle 94, entre calles 9 y 11;

- Agrupación Social, cultural y Religiosa Africanista y Umbandista (A.S.R.A.U), localizada en el Barrio Esperanza, sobre el Camino Gral. Almirante Brown №780.

El análisis permitió identificar la existencia de una variedad de centros religiosos en el área (Mapa 15), que se encuentran distribuidos de forma relativamente uniforme, en todo el sector de estudio; otorgando a la población la posibilidad de acceder a diversos espacios para el desarrollo del culto y garantizando la diversidad en la profesión de las diferentes religiones. 

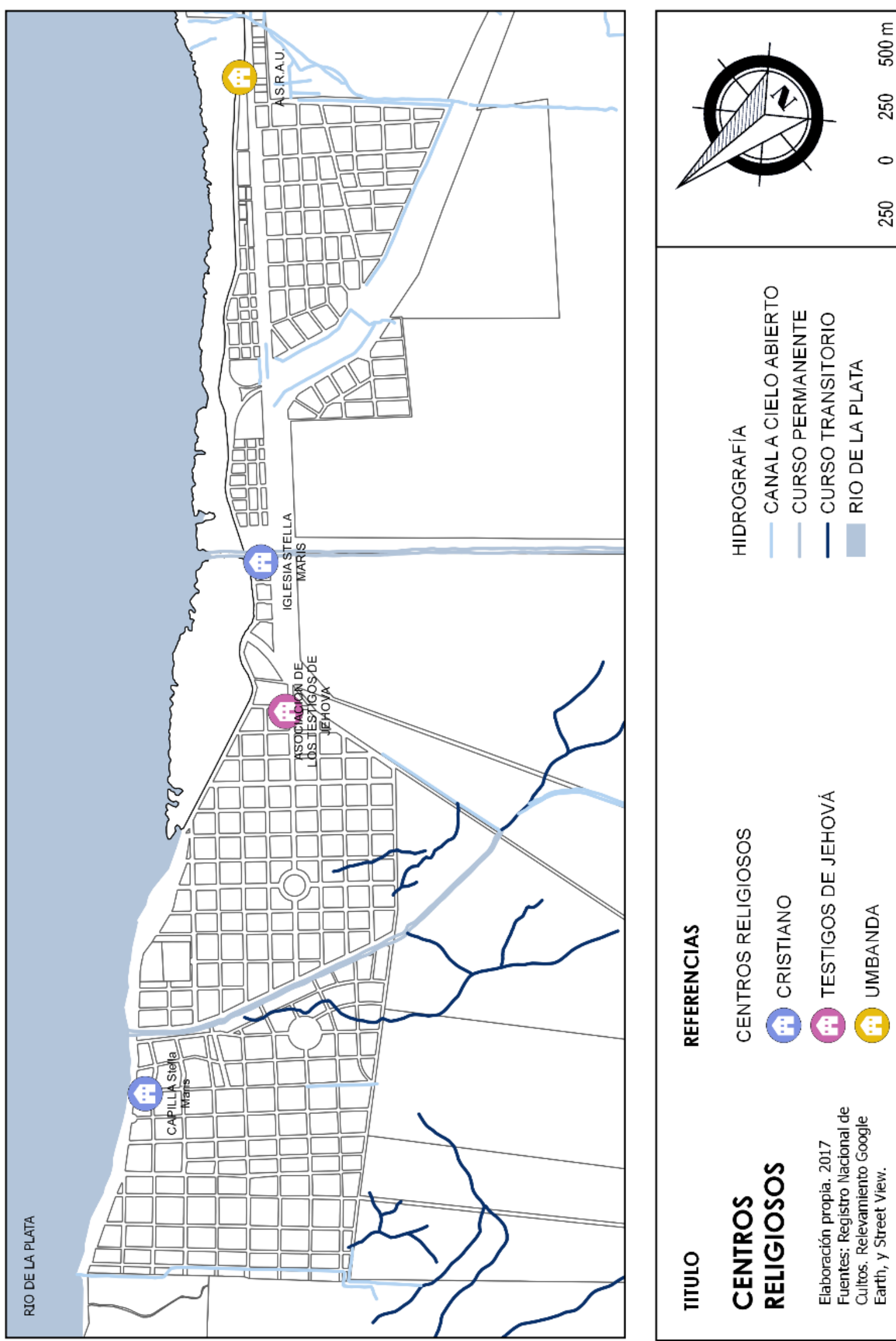
En términos de la representación que estos espacios poseen sobre el territorio, pudo identificarse que la Iglesia Stella Maris es la que tiene mayor presencia, asociada también al rol en el proceso de conformación de la localidad y a su localización como parte del centro cívico de la localidad (Figura 59, Imagen A).

En contraposición, la Capilla Stella Maris ubicada en cercanías de la Reserva de la selva marginal, presenta condiciones de degradación edilicia e incluso resulta dificultosa su localización producto del avance de la vegetación (Figura 59, Imagen B).

La Asociación de los Testigos de Jehová, también posee una presencia relevante, pudiendo reconocerse el establecimiento localizado en el Barrio Punta Lara (Casco) e identificándose la pertenencia como centro religioso (Figura 59, Imagen C).

El caso de la Agrupación Social, cultural y Religiosa Africanista y Umbandista (A.S.R.A.U) es llamativo, ya que resulta difícil identificar el espacio que se utiliza para el desarrollo del culto debido a que, como puede observarse en el Figura 59 (Imagen D), no hay elementos que permitan asociar este espacio a un centro en el que se desarrollen actividades de este tipo. Pese a esto, algunos encuestados reconocieron la impronta que tiene este culto en la zona ("Ios umbandas tienen fiestas, en las que hacen ofrendas al Río, y se juntan acá en la playa para hacer eso" manifestaba, por ejemplo, uno de los encuestados).
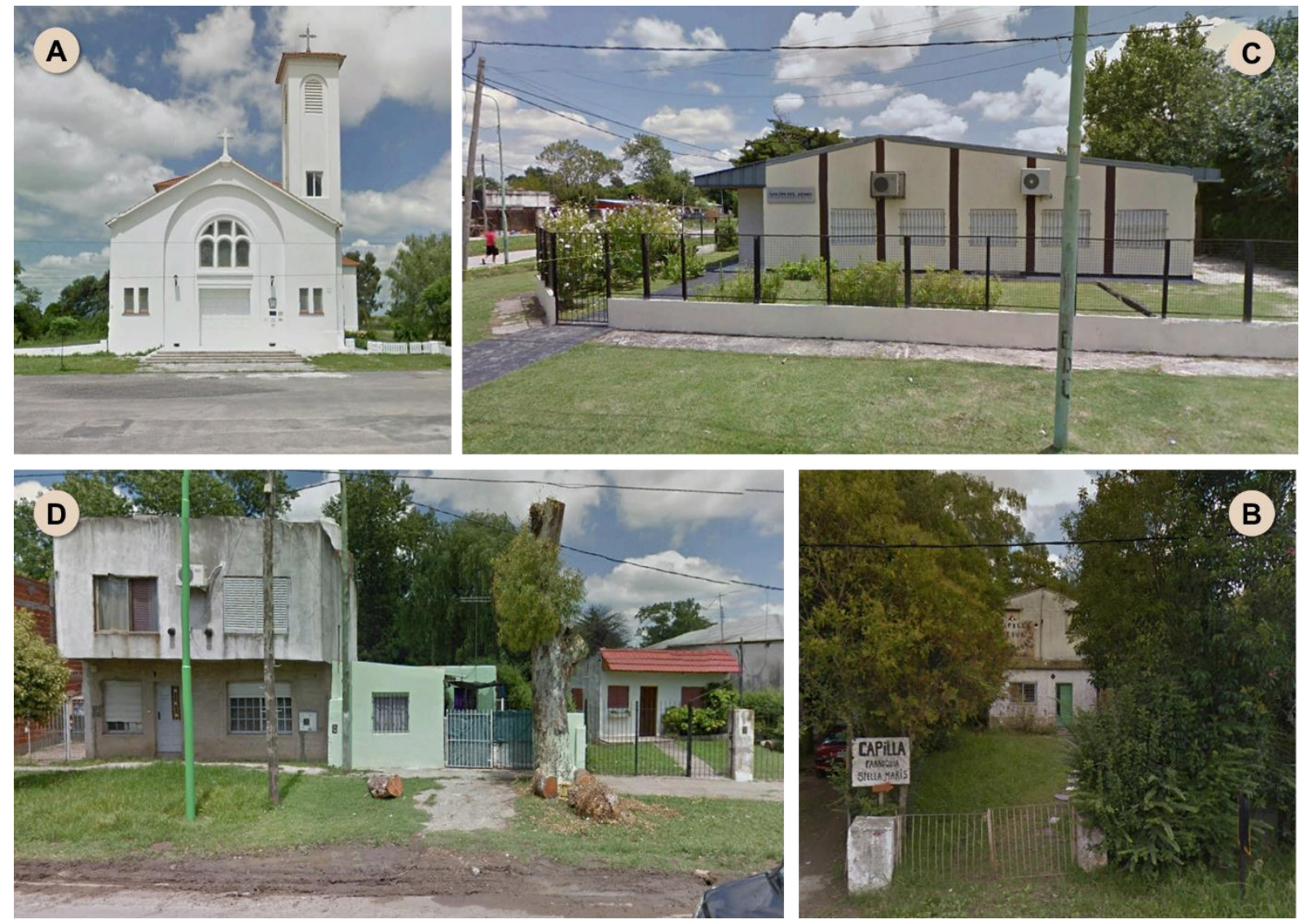

Figura 59. Centros Religiosos, Punta Lara 


\section{B | Análisis cualitativo del Indicador}

Como fuera observado en el estudio cuantitativo, el indicador referido a la diversidad religiosa en la localidad resultó de difícil evaluación debido a que el interrogante no tuvo un elevado nivel de aceptabilidad, lo que condujo a que la mayor parte de los encuestados prefiriera no responder a la consulta (representando un 45,7\% aproximadamente). Sin embargo, del 54,3\% restante, sólo el 14,3\% refirió acercarse a alguno de los centros religiosos de la localidad, mientras que un $40 \%$ se traslada a otros centros fuera de Punta Lara (Figura 60).

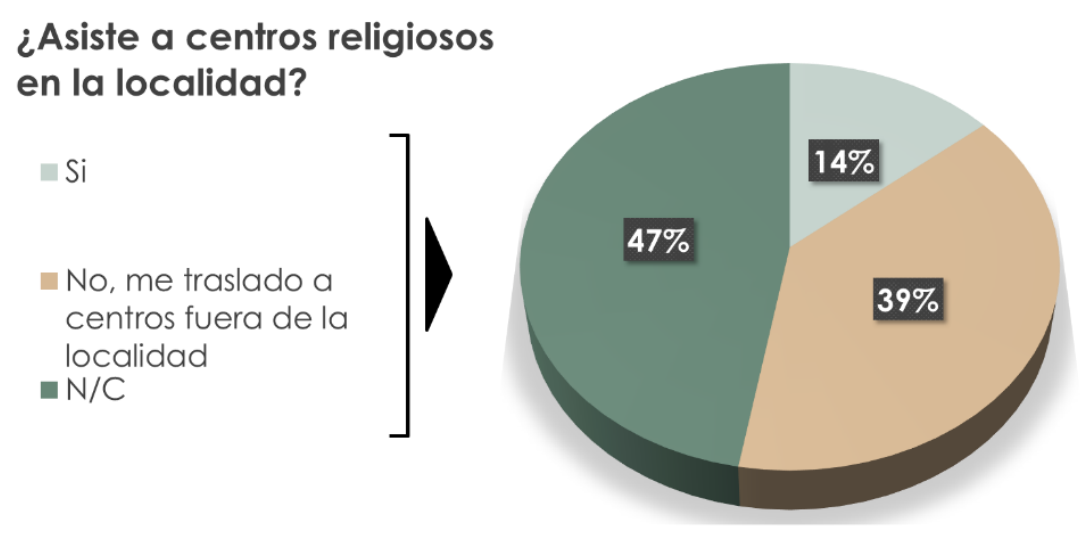

Figura 60. Resultados encuesta: Asistencia a centros religiosos de la localidad. Elaboración propia, 2019

\section{C| Síntesis del Indicador}

En síntesis, en términos cuantitativos el indicador de centros religiosos dio cuenta de la presencia relevante en la localidad de diversos centros religiosos a los cuales la población puede asistir. Sin embargo, la interpelación de estos datos con la visión de los encuestados resultó compleja, debido a que una parte importante de los mismos prefirió no responder consultas asociadas a este indicador.

Pese a esto, pudo observarse que existe una diversidad en la práctica de la religión y que incluso los habitantes que no asisten a centros religiosos, conocen la existencia de diversos centros y religiones y refieren a la presencia que tienen estas sobre el territorio, manifestando estar al tanto, por ejemplo, de celebraciones y festividades que se desarrollan en la localidad.

En conclusión, la importancia de este indicador en función del derecho a la ciudad residía en la capacidad de profesar libremente la religión, sin distinciones de ningún tipo; cuestión que pudo comprobarse a partir de las inferencias realizadas tanto a partir del análisis cuantitativo como del estudio cualitativo. 


\section{FICHA METODOLÓGICA}

descripción

El indicador de "Centros Religiosos" busca aportar información en relación a la existencia de equipamientos que permitan el desarrollo de actividades religiosas y de culto, constituyendo también soportes para actividades de reunión y socialización entre los miembros de la comunidad

\section{objetivo de la medición}

Se trata de un indicador relevante en pos de garantizar el derecho a la ciudad que incluso se encuentra reconocido en la Constitución Nacional Argentina, específicamente en su artículo 14, que manifiesta que todos los habitantes de la Nación gozan de múltiples derechos, entre los que reconoce el derecho a trabajar, el derecho a exponer ideas libremente; e incluye el derecho a profesar libremente el culto, sin distinción de la orientación del mismo preguntas conductoras

¿Se observan centros religiosos en el área? ¿Hay diversidad de culto?

\section{limitaciones del indicador}

El análisis que se realiza es a partir de técnicas cuantitativas que se interpelan mediante el uso de técnicas cualitativas que aporten la visión de actores residentes en el área de estudio

modalidad de medición - tratamiento del dato

El tratamiento de la información estará orientado a:

1. La localización en el espacio de los Centros Religiosos que se encuentren en el sector de análisis. Se realizará la identificación de los mismos a partir del análisis de imágenes satelitales y visualizadores, sumado al Registro Nacional de Cultos

2. Reconocimiento de las características de los centros religiosos, buscando identificar a qué culto pertenecen, a fin de evaluar la DIVERSIDAD de culto

3. Se interpelarán los resultados obtenidos a partir de la percepción de población residente en el área de estudio, mediante el desarrollo de encuestas

\section{escala de medición}

El indicador "centros religiosos" se analizará en la escala MACRO

\section{fuentes de información}

Visualizadores: Street View

Análisis de Imagenes Satelitales: Google Earth

Registro Nacional de Cultos

Encuestas: Población residente en el área de estudio

$\begin{array}{lll}\text { variable } & \text { dimensión } & \text { factibilidad de análisis del indicador } \\ \text { CIUDAD INCLUYENTE } & \text { RECREACIÓN } & \text { ALTA }\end{array}$




\subsection{6 | Variable CIUDAD INCLUYENTE}

Los datos obtenidos de cada uno de los indicadores precedentes, permiten la construcción de la variable ciudad incluyente, tomando en consideración tanto los datos cuantitativos como la apreciación de la población encuestada en relación a los mismos.

Inicialmente, a modo de síntesis se construyó el Mapa 16 en el que se localizaron cada uno de los centros identificados previamente, en relación a los barrios del área de estudio.

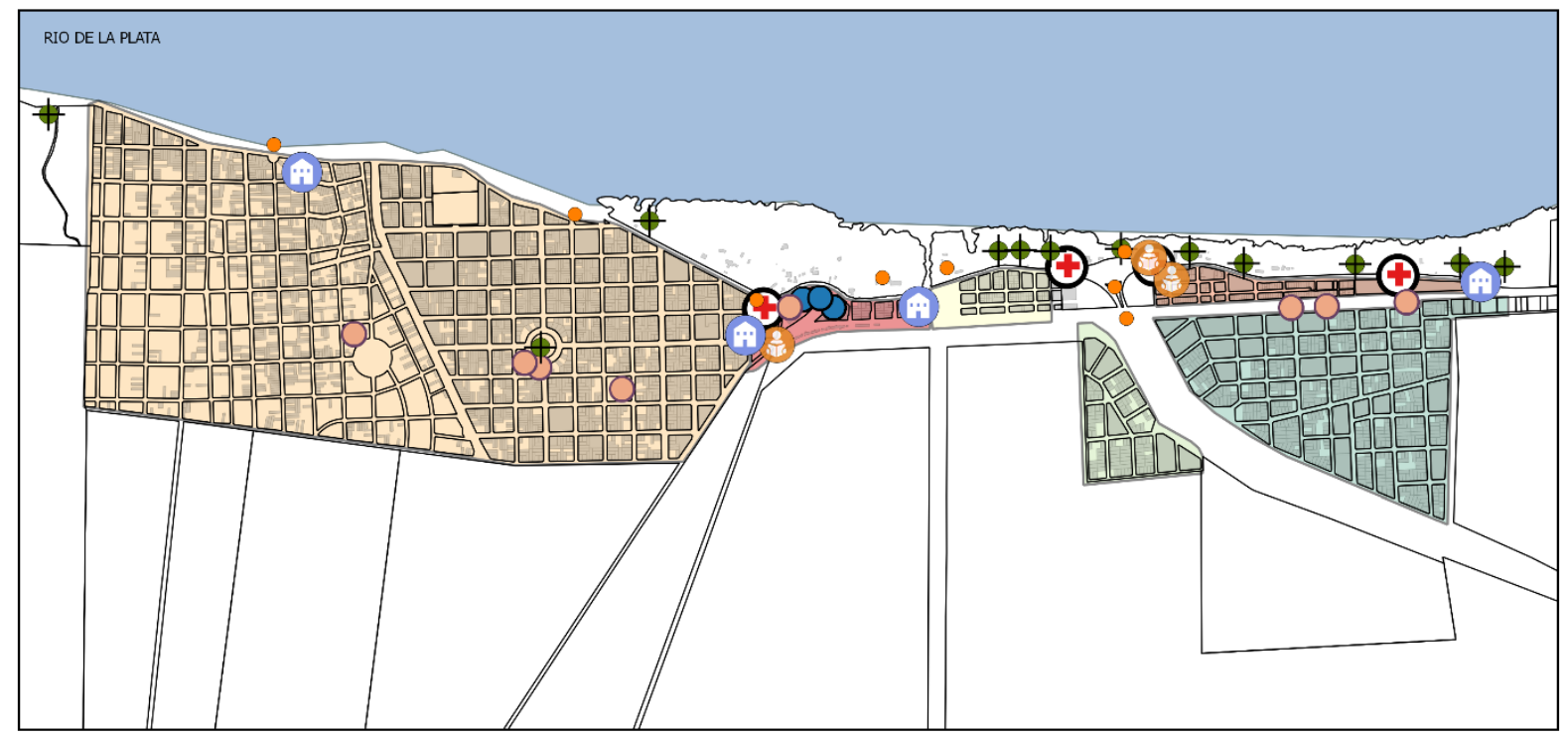

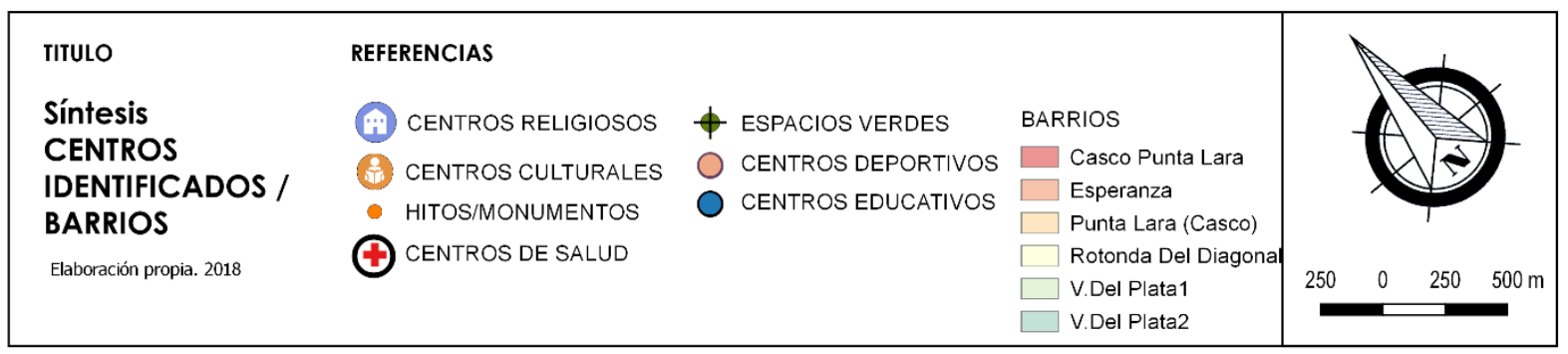

Mapa 16. Síntesis: Centros Identificados / Barrios del área de Estudio. Elaboración propia. 2019

\section{A | Análisis cuantitativo de la variable Ciudad Incluyente}

El primer aspecto a resolver para la construcción de la Variable Ciudad Incluyente, fue la ponderación de los indicadores que permitiera luego establecer relaciones y articulaciones que permitieran el diálogo entre los diferentes aspectos estudiados.

A estos efectos, se utilizó el método de ponderación por ranking recíproco desarrollado por Jacked Malczewski (1999), definiendo un "ranking de importancia" para cada uno de los indicadores, donde aquellos más importantes adquirieron el valor 1, los siguientes el valor 2 y así sucesivamente. Seguidamente, se aplicó la siguiente fórmula:
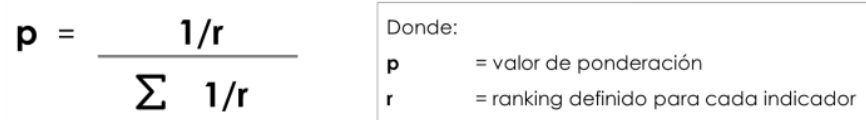
Con esto presente, se definió el ranking de importancia de cada uno de los indicadores y se aplicó la fórmula para definir el valor de ponderación (Tabla 2).

\begin{tabular}{llll} 
Indicador & $\mathbf{r}$ & $\mathbf{1 / r}$ & $\mathbf{p}$ \\
\hline I. Espacios Verdes Públicos & 2 & 0,5 & 0,158 \\
I. Centros Deportivos Recreativos & 3 & 0,33 & 0,104 \\
\hline I. Centros Culturales & 3 & 0,33 & 0,104 \\
\hline I. Centros Educativos & 1 & 1 & 0,316 \\
\hline I. Centros de Salud & 1 & 1 & 0,316 \\
\hline TOTAL & & & \\
\hline
\end{tabular}

Tabla 2. Ponderación de Indicadores. Elaboración propia. 2019

Cabe destacar que, pese a que resulta dificultoso identificar mayores y menores importancias cuando se trata de garantizar derechos, se construyó este valor de ponderación a partir de una doble articulación de la subjetividad propia de quien desarrolla la investigación, por un lado, y las opiniones de los encuestados en relación a la importancia que pudo inferirse que cada uno de los indicadores presentaba por el otro.

De esta forma, se consideró que tanto el acceso a la educación (Indicador de Centros Educativos) como a la salud (Indicador de Centros de Salud), resultaban de mayor importancia en pos de garantizar una Ciudad Incluyente y acercarse cada vez más a la satisfacción del derecho a la ciudad y, en concordancia con esto, una de las mayores necesidades manifestadas por la población encuestada.

En segunda instancia, se ubicó al indicador correspondiente a la dimensión Recreación, de Espacios Verdes/Públicos, debido a la impronta que estos espacios tienen en la conformación de la localidad y las impresiones que generan en la percepción de la población.

Por último, se ubicaron los indicadores de Centros Deportivos Recreativos y de Centros Culturales, debido a que se contempla que es posible que mayor cantidad de población acceda a estos servicios y actividades en otros territorios, que no sean específicamente en su área de residencia -apoyados, nuevamente, en las indagaciones realizadas-. Tomando estos factores en cuenta, se estandarizaron los valores de acuerdo al ranking, aplicando la siguiente fórmula:

\section{("Espacios Verdes Públicos" x 0,158) + ("Centros Deportivos Recreativos" x 0,104) + ("Centros Culturales" x 0,104) + ("Centros Educativos" x 0,316) + ("Centros de Salud" x 0,316)}

Con la información obtenida, se construyó el mapa síntesis de la variable Ciudad Incluyente (Mapa 17) aplicando para su representación el método de intervalos iguales, basado en la división equitativa de todos los datos que se presentan, definiendo similar amplitud para todos ellos. 

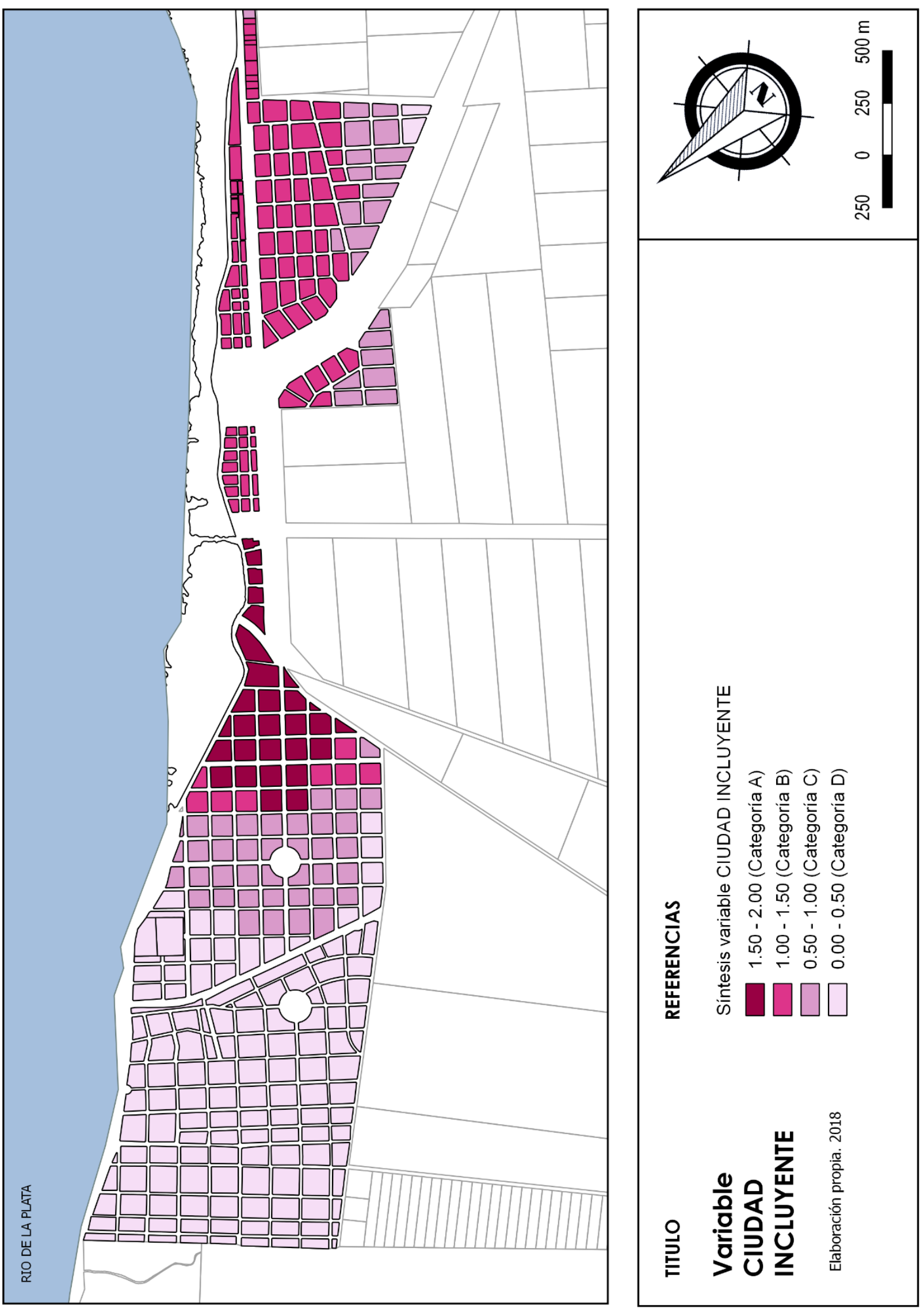

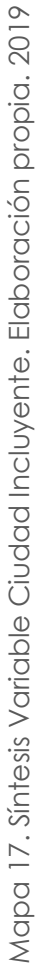


En este caso se construyeron cuatro categorías en términos del alcance de la satisfacción del derecho a la ciudad incluyente (Figura 62).

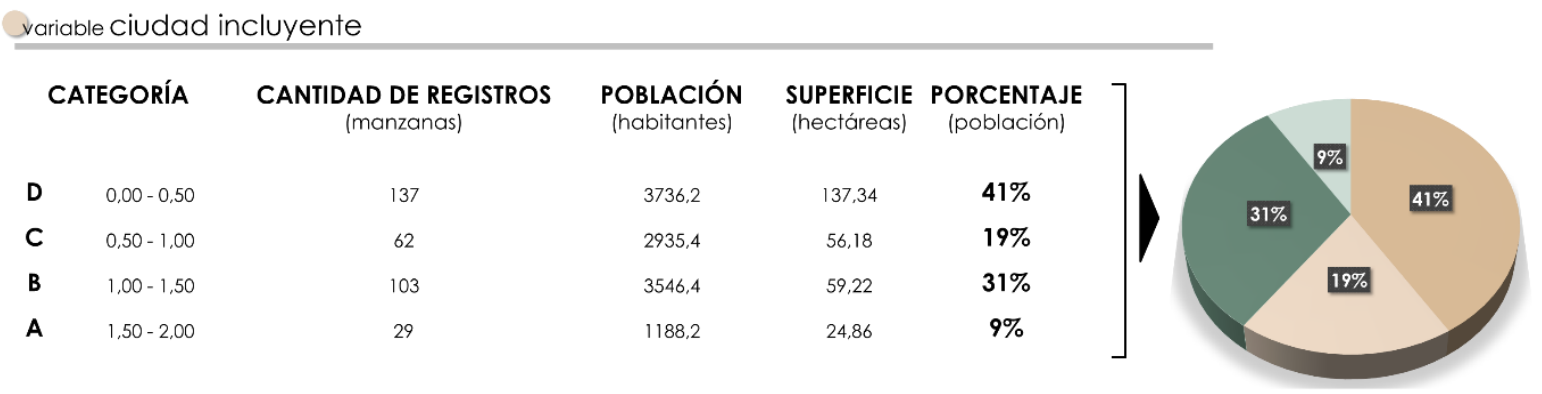

Figura 62. Síntesis Variable Ciudad Incluyente. Elaboración propia. 2019

La categoría más deficitaria (Categoría D), representada por valores entre 0.00 y 0.50, se observó en un total de 137 registros (manzanas) que presentaban escasa o nula cobertura de los indicadores estudiados, lo que implica un $41 \%$ de la totalidad de los registros de la localidad. Se trata de manzanas que, en general, se encuentran alejadas de establecimientos educativos y tienen un nulo o insuficiente acceso a equipamientos deportivos, recreativos y culturales; sumado a encontrarse en sectores alejados de espacios verdes/públicos que permitan el desarrollo de otras actividades de esparcimiento y recreación.

En términos de localización, esta categoría se ve representada por las manzanas ubicadas en el Oeste de la localidad, cercanos a la Reserva Natural de Punta Lara, y algunos sectores del Sur de Villa del Plata. En el caso de las manzanas más cercanas a la Reserva, la criticidad puede interpretarse como menor, debido a que se trata de zonas con una escasa ocupación y consolidación urbana en la actualidad. A modo de ejemplo de las situaciones que pueden observarse, se desarrollaron fichas de análisis de manzanas representativas de esta categoría.

Se tomó en principio la manzana identificada con la nomenclatura catastral: Mz 79 / Circunscripción IV / Sección A. En ella pudo observarse que presentaba cobertura regular tanto de espacios verdes/públicos como de centros deportivos recreativos. Sin embargo, en términos de los indicadores de centros culturales, educativos y de salud, pudo reconocerse que no existía cobertura de los mismos, debido a que se encontraba alejada de las distancias mínimas definidas para el acceso a los mismos (Figura 63).

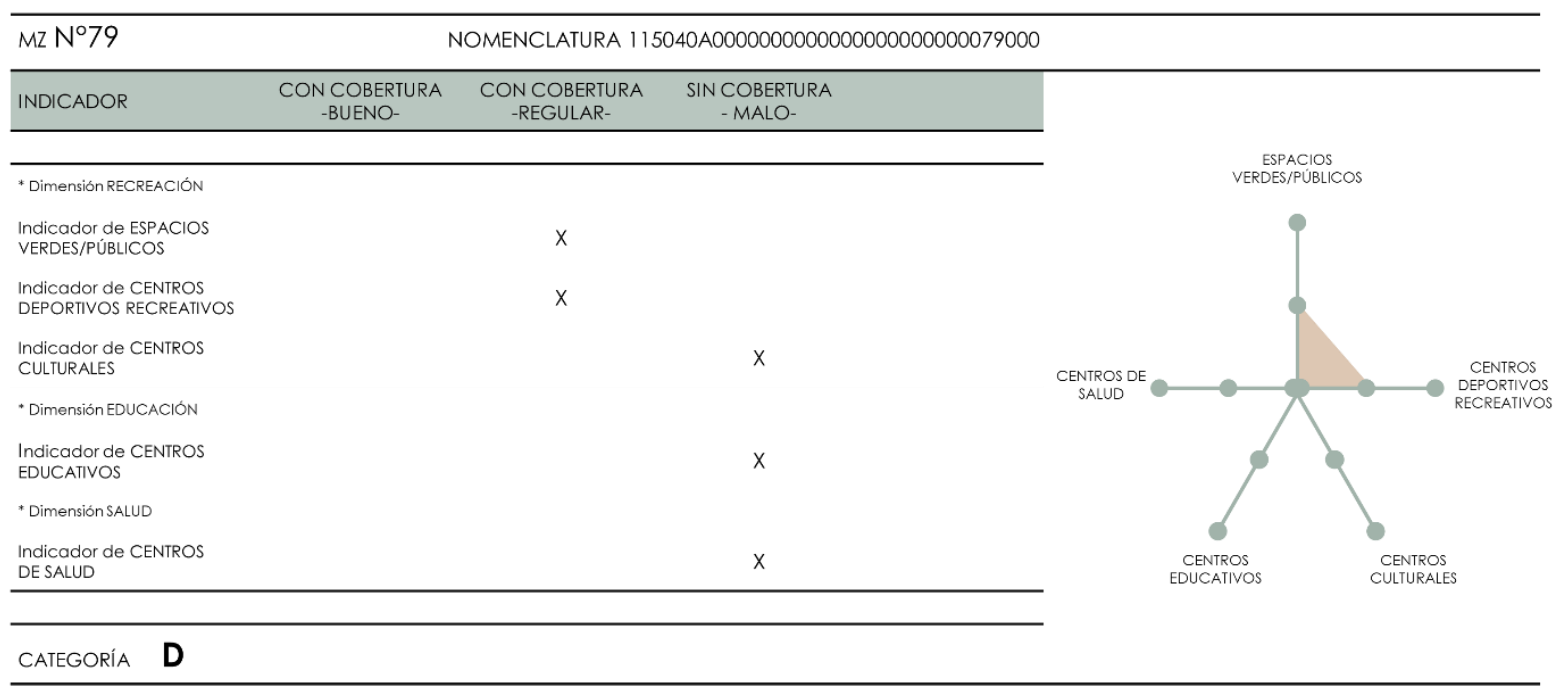

Figura 63. Ficha Síntesis de Manzana №79, a partir del análisis de Indicadores de Ciudad Incluyente. Elaboración propia. 2019 
Otro ejemplo de la categoría D estudiado fue el de la Manzana 66 / Circunscripción IV / Sección A, que presentaba indicadores aún más críticos, debido a que sólo pudo observarse una cobertura de carácter regular al analizar el indicador de espacios verdes/públicos; mientras que en el resto de los indicadores se identificó una condición de mala cobertura o, incluso, sin cobertura alguna (Figura 64).

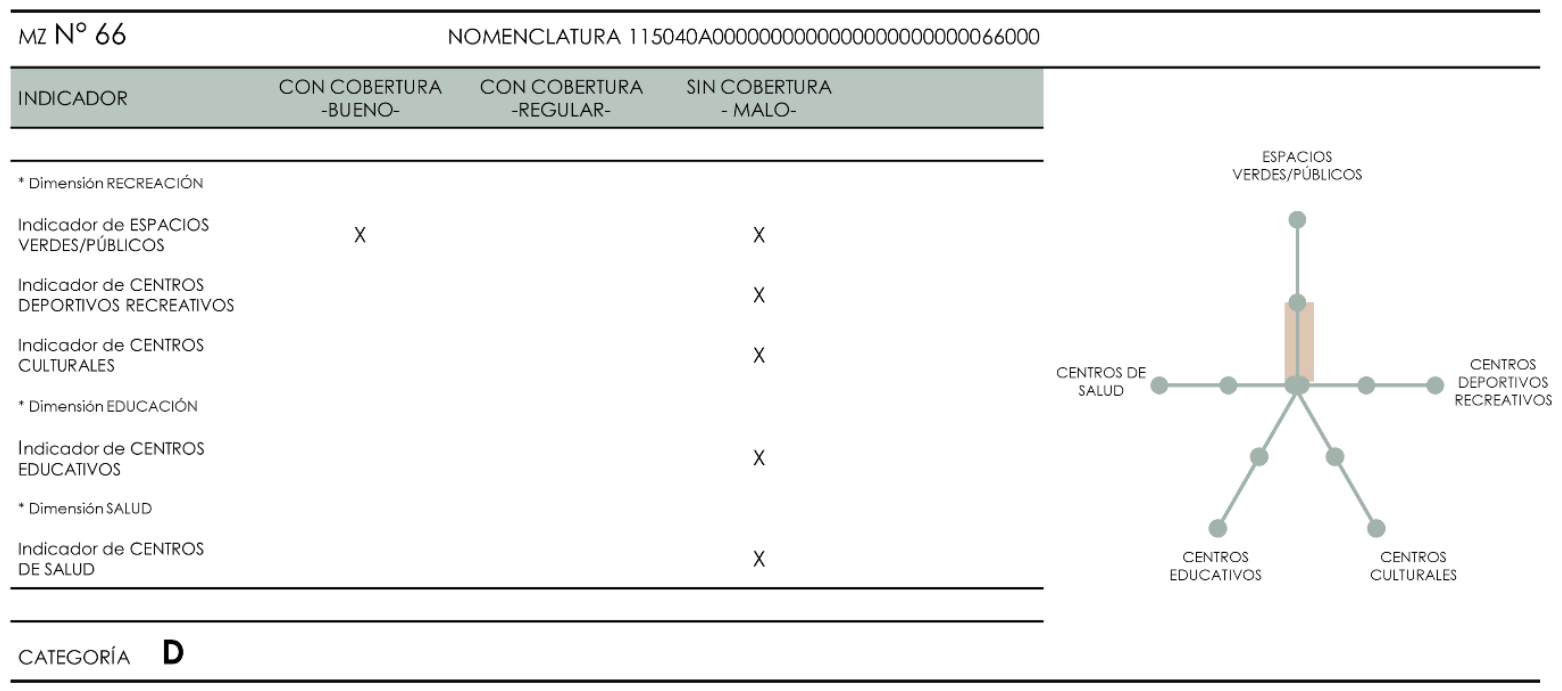

Figura 64. Ficha Síntesis de Manzana N66, a partir del análisis de Indicadores de Ciudad Incluyente. Elaboración propia. 2019

La siguiente categoría (C), definida entre los valores 0,50 y 1,00, presentó una mejora leve en algunos de los indicadores, principalmente en aquellos definidos como de mayor importancia, respondiendo a localizaciones más cercanas al subcentro de la localidad de Punta Lara. Se trataba, en general, de sectores con mayores porcentajes de ocupación residencial que las manzanas correspondientes a la categoría D, con un proceso de ocupación y consolidación reciente. Esta categoría se observó en un total de 62 registros, que representan un 19\% de los registros de la totalidad del área de estudio.

Se estudiaron, nuevamente a modo de ejemplo, dos manzanas. La primera de ellas, identificada por la nomenclatura Mz 42 / Circunscripción IV / Sección A, presentaba una buena cobertura en términos de los indicadores de espacios verdes/públicos y de centros deportivos recreativos; pero al estudiar los indicadores de centros culturales, educativos, y de salud, se observaba una cobertura nula o muy baja., lo que reducía considerablemente el puntaje para considerarse como satisfecho el derecho a una ciudad incluyente (Figura 65).

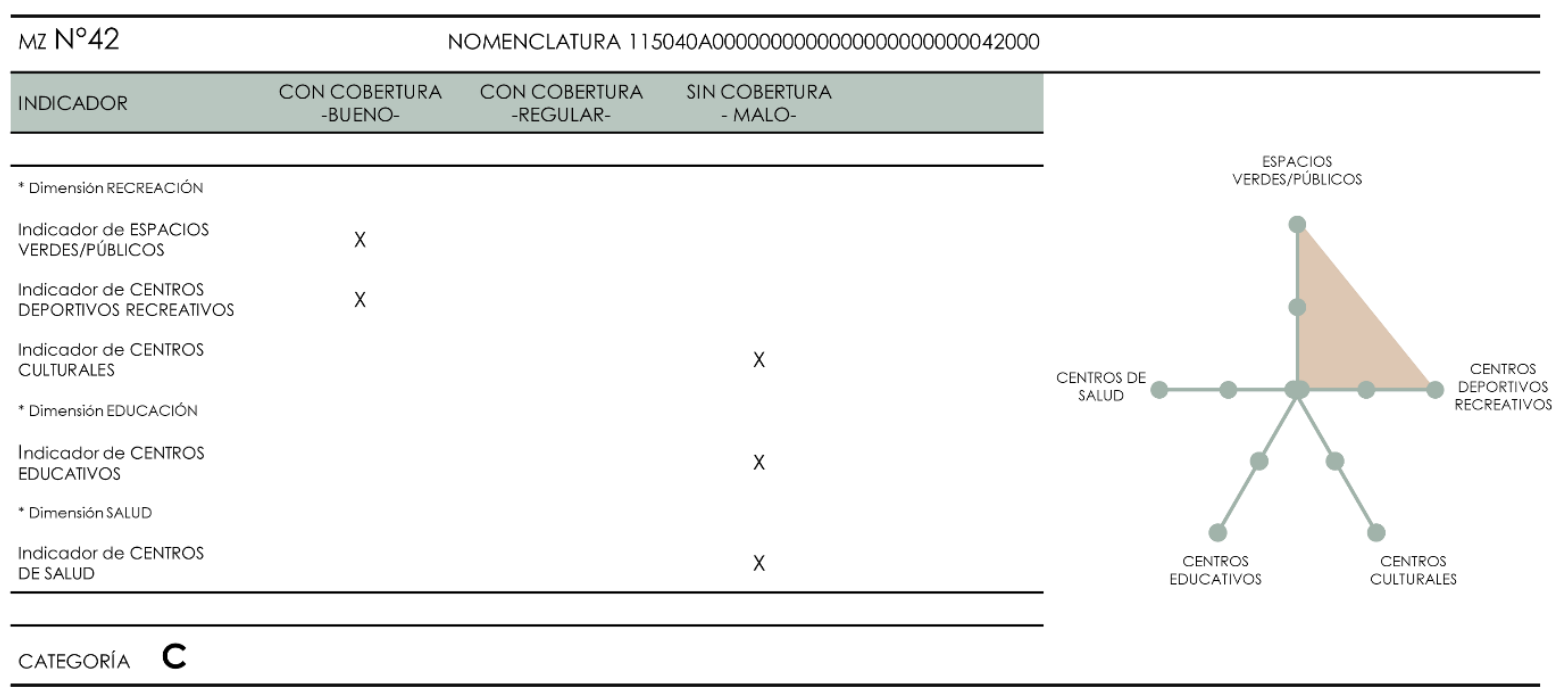

Figura 65. Ficha Síntesis de Manzana №42, a partir del análisis de Indicadores de Ciudad Incluyente. Elaboración propia. 2019 
La segunda de las manzanas estudiadas, correspondía a la Manzana 7 / Circunscripción IV, Sección A. En ella, pudo identificarse cierta mejora, principalmente en términos de cobertura del indicador de centros de salud sobre el que se observó una cobertura regular. Los indicadores de espacios verdes/públicos y de centros deportivos recreativos son los que, nuevamente, presentan los mejores valores, mientras que no se observó cobertura (cobertura baja o nula) en relación a centros culturales y educativos (Figura 66).

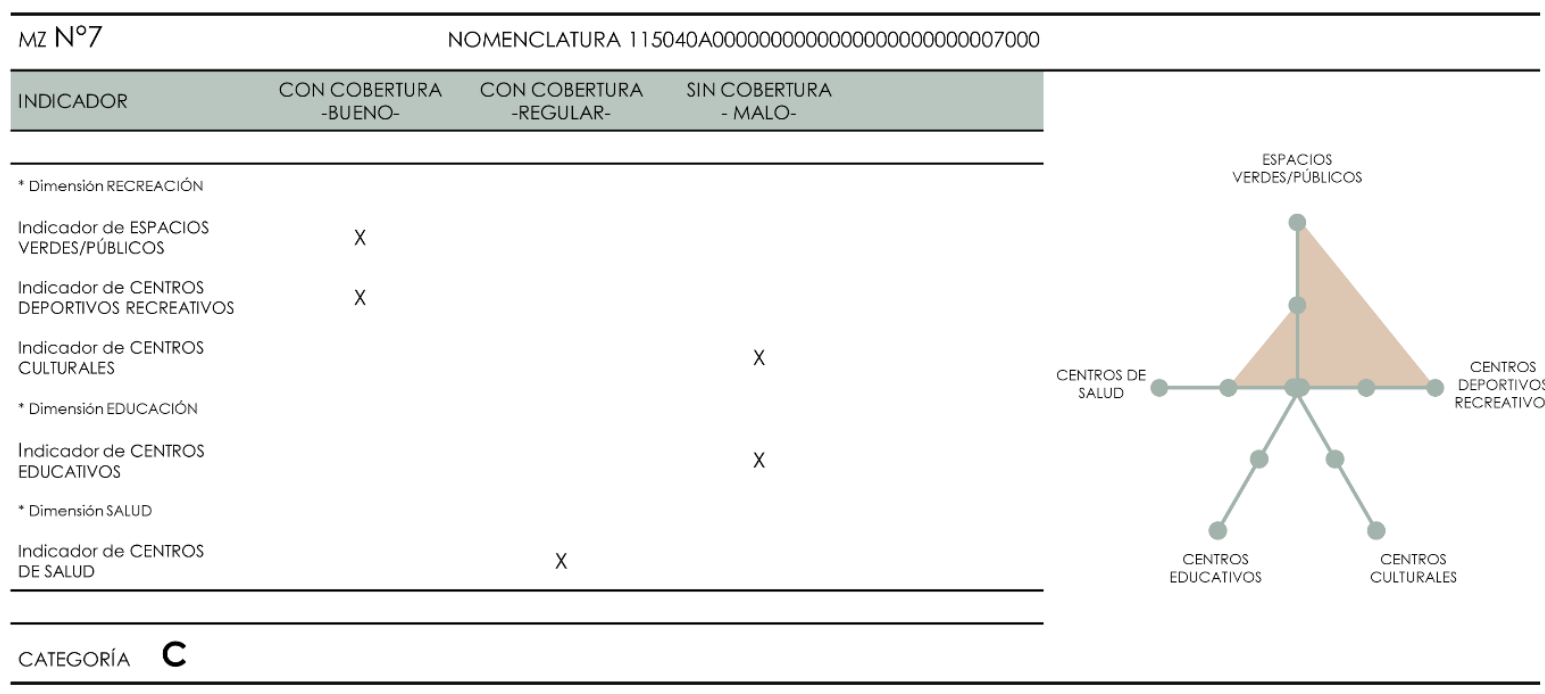

Figura 66. Ficha Síntesis de Manzana N7, a partir del análisis de Indicadores de Ciudad Incluyente. Elaboración propia. 2019

La categoría B, representada por valores entre 1,00 y 1,50, responde a indicadores más cercanos a una satisfacción plena del derecho a una ciudad incluyente, con mejores coberturas en términos de espacios verdes públicos, mayor acceso a centros deportivos y recreativos y, fundamentalmente mayor cobertura de los servicios educativos y de salud. Se trata de las manzanas más cercanas al borde costero, en el que pudo observarse mayor presencia de espacios verdes, equipamientos de diferentes tipos, incluso institucionales. Esta categoría pudo reconocerse en un 31\% de los registros del área (103 registros), contemplando a 3546 habitantes aproximadamente.

Dentro de estos parámetros, se estudió la Manzana 7A / Circunscripción IV / Sección L; observándose una cobertura de características adecuadas y favorables en tres indicadores fundamentales para el derecho a la ciudad incluyente: el indicador de espacios verdes/públicos, el de centros deportivos recreativos y el de centros de salud. Además, se identificó una cobertura, de características regulares en el resto de los indicadores contemplados, con lo cual, pese a que no se trata de una condición óptima, los indicadores evidenciaron una mejora considerable (Figura 67). 


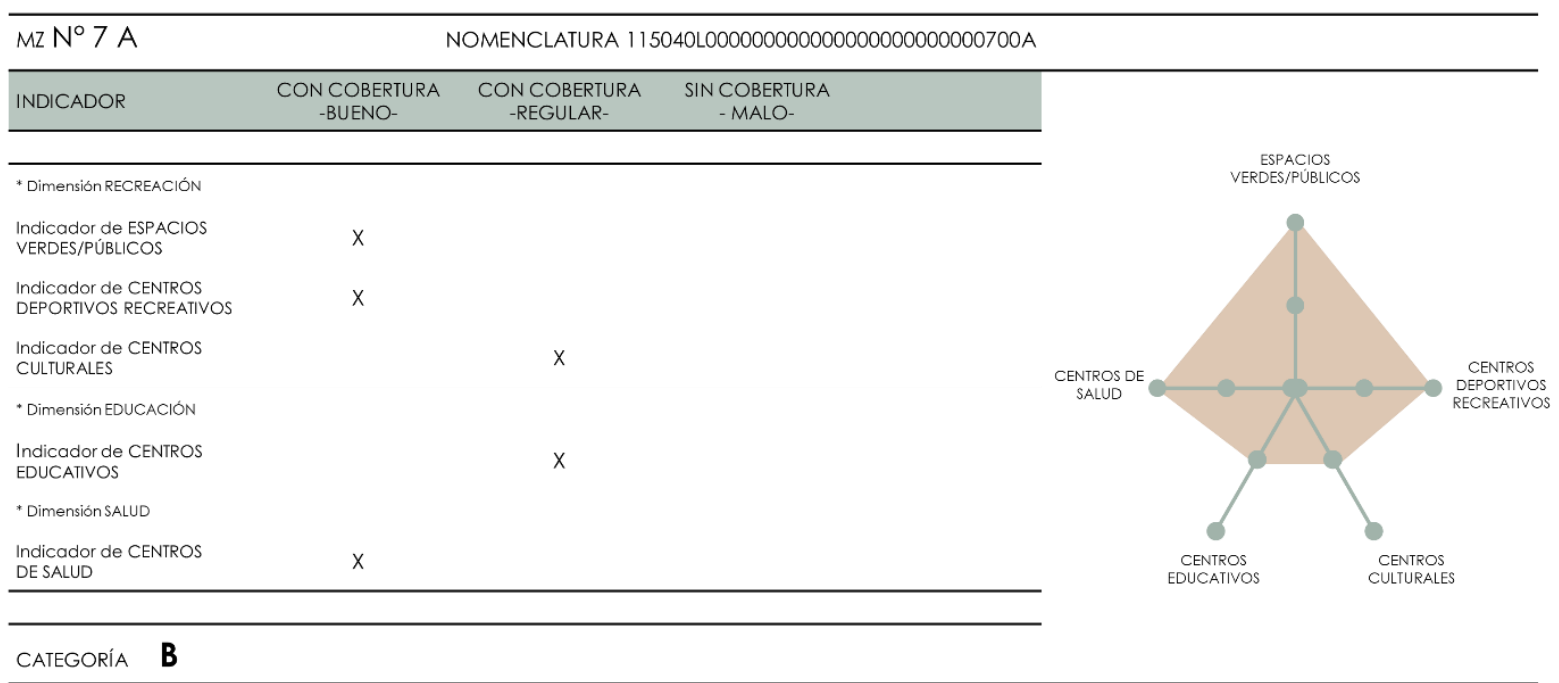

Figura 67. Ficha Síntesis de Manzana N7A, a partir del análisis de Indicadores de Ciudad Incluyente. Elaboración propia. 2019

Situación similar pudo observarse en la Manzana 20 / Circunscripción IV / Sección A, en que las mejores coberturas se identificaron en el análisis de los indicadores de espacios verdes públicos, centros deportivos recreativos y centros de salud; así como una cobertura regular en términos de centros educativos. Sin embargo, el acceso a centros culturales resultó inadecuado e insuficiente (Figura 68).

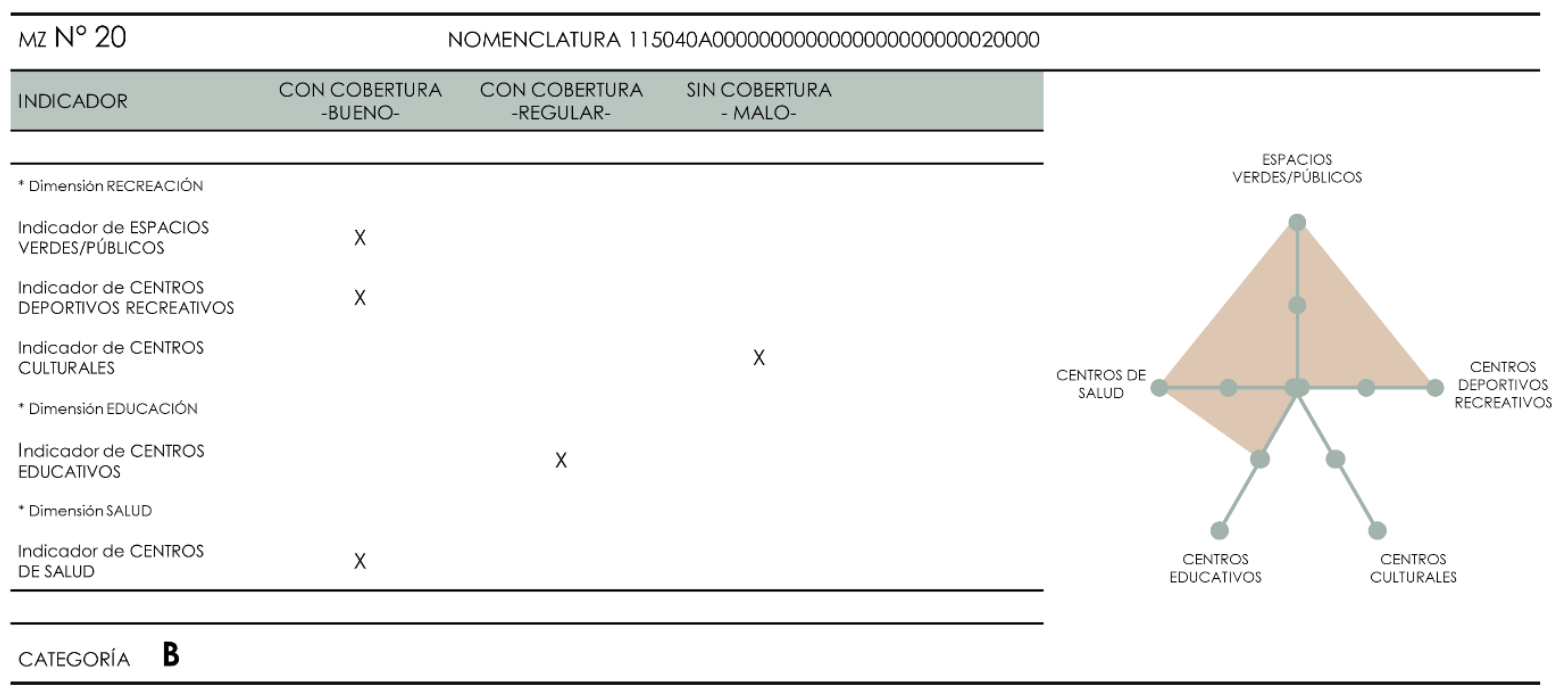

Figura 68. Ficha Síntesis de Manzana №20, a partir del análisis de Indicadores de Ciudad Incluyente. Elaboración propia. 2019

La categoría A, representó los mejores puntajes en términos de cobertura y acceso a los indicadores definidos para la variable ciudad incluyente. Sin embargo, se observó que solamente un $9 \%$ de los registros (29 manzanas específicamente) presentaban estos valores, lo que representaba un total de 1188 habitantes. Se trataba de una serie de manzanas del área central, en las que predominan los usos mixtos, es decir, que además del uso residencial (predominante en toda el área de estudio) es el espacio de localización de la mayor parte de los centros institucionales, así como centros educativos, religiosos y espacios recreativos deportivos más relevantes del área de estudio (Figura 69). 


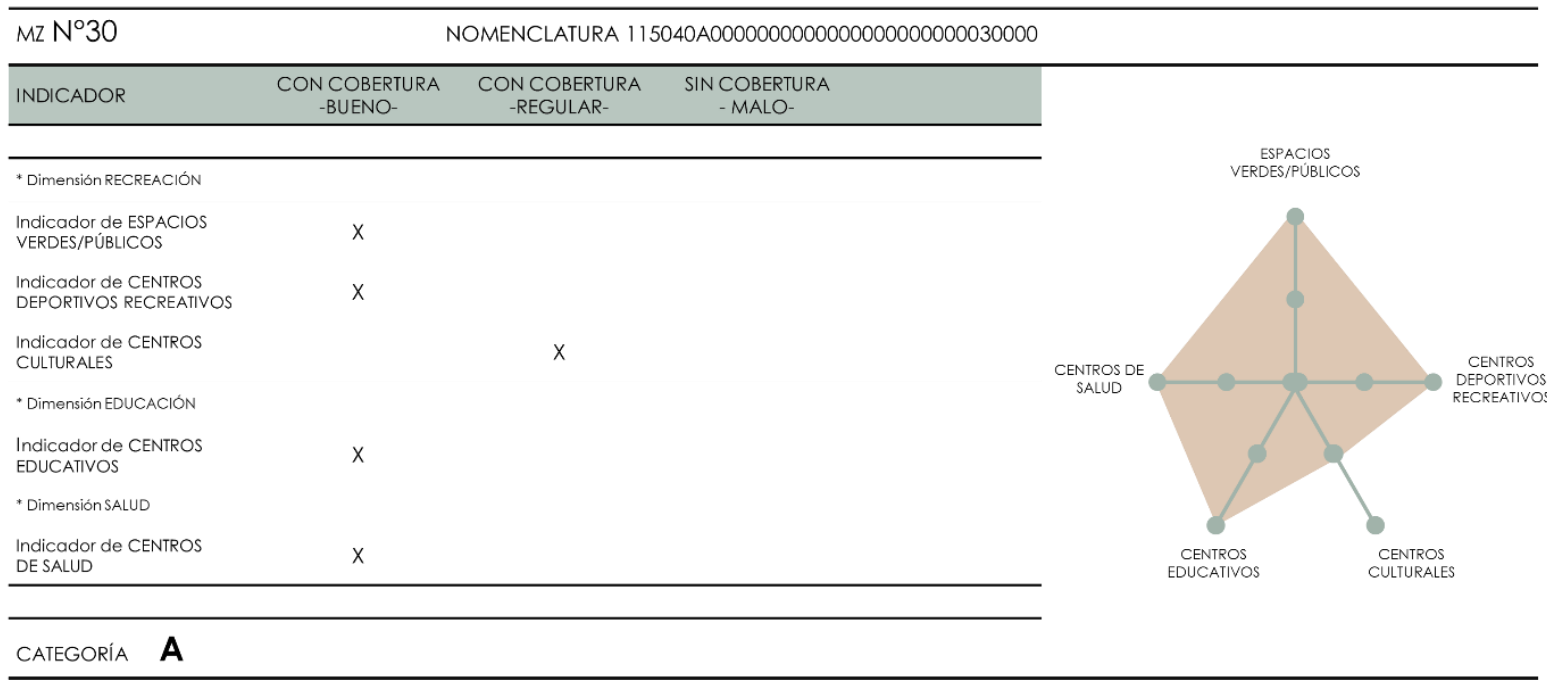

Figura 69. Ficha Síntesis de Manzana №30, a partir del análisis de Indicadores de Ciudad Incluyente. Elaboración propia. 2019

La última de las manzanas analizadas, presentó la situación óptima de satisfacción del derecho a la ciudad incluyente, debido a que todos los indicadores presentan una buena cobertura, acorde a los requerimientos fundamentales para cada uno de ellos (Figura 70).

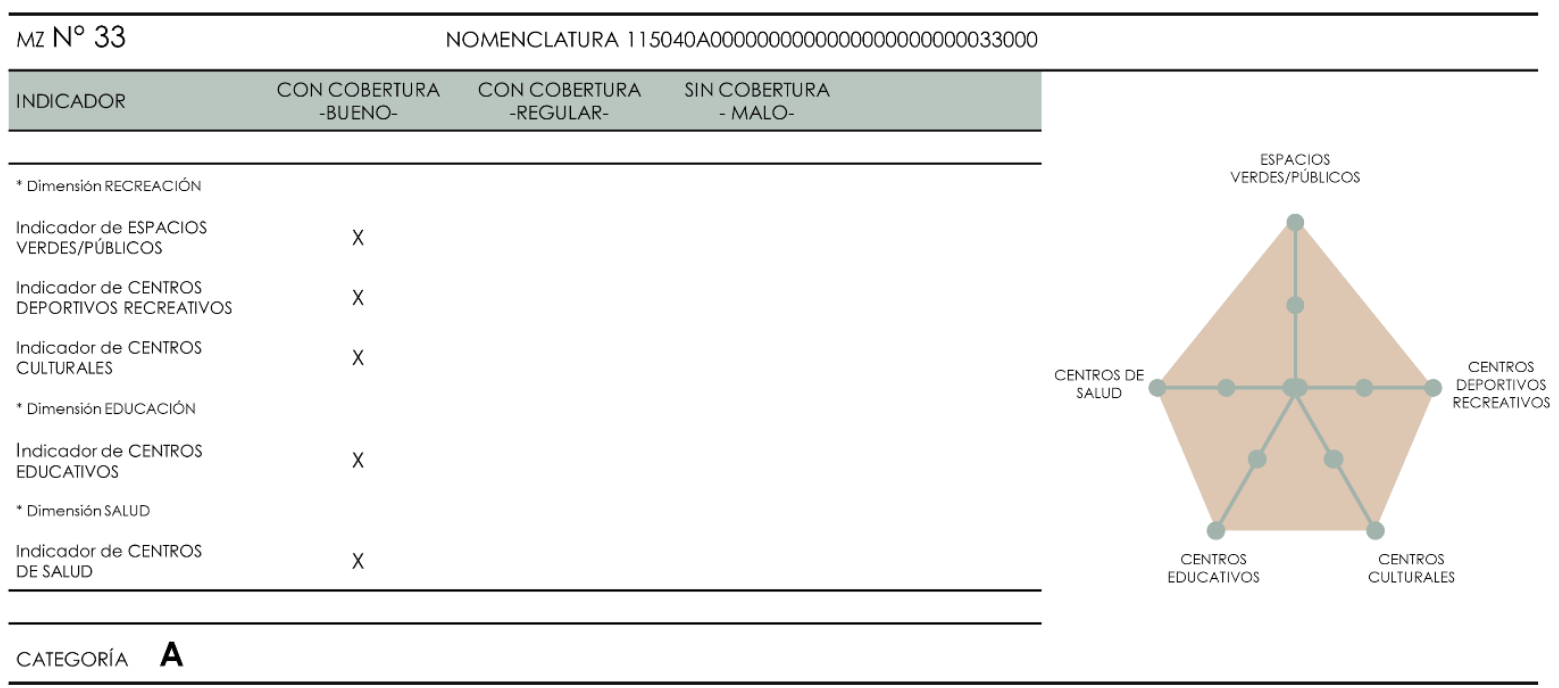

Figura 70. Ficha Síntesis de Manzana №33, a partir del análisis de Indicadores de Ciudad Incluyente. Elaboración propia. 2019

En conclusión, si consideramos que las categorías más comprometidas son las categorías $D$ y C, pudo observarse una situación crítica debido a que la sumatoria entre ambas reunió a un $67 \%$ de la totalidad de los registros de la localidad, representados por un conjunto de aproximadamente 7295 habitantes que encuentra complicaciones para la satisfacción del derecho a la ciudad incluyente, alejándose, por ende, de la satisfacción plena del derecho a la ciudad.

Sin embargo, una de las constantes que pudo observarse en el estudio de la variable ciudad incluyente fue que las mejores coberturas se daban en relación con los indicadores de espacios verdes/públicos y centros deportivos recreativos. Puede interpretarse que esto se debe a que en el partido de Ensenada se observa, en general, una mayor cantidad de equipamientos de este tipo, sumado a su condición de localidad costera y turística que genera espacios de los cuales la comunidad puede apropiarse; fomentando la socialización, la construcción de ciudadanía y generando situaciones inclusivas, propias de los fundamentos del derecho a la ciudad. 


\section{B | Análisis cualitativo de la variable Ciudad Incluyente}

El análisis cualitativo de la variable ciudad incluyente se realizó a partir de las respuestas brindadas por la población encuestada, en función de la localización de su lugar de residencia.

Así, en relación a la categoría D -que cuantitativamente es la que presenta las mayores deficiencias dentro de esta variable- pudo observarse que la percepción de la población coincide con las valoraciones cuantitativas, considerando que el acceso a espacios verdes/públicos es insuficiente y los mismos presentan condiciones regulares; que debe trasladarse para satisfacer necesidades asociadas a actividades deportivas y culturales (calificando los centros existentes como "regulares"); y, de igual modo, para el acceso a la salud y la educación recurre a centros fuera del territorio de pertenencia.

Con respecto a la categoría C, la percepción de los encuestados presentó algunas mejoras en relación a los espacios verdes/públicos principalmente, manifestando concurrir a estos espacios regularmente con familia y amigos; y también en relación a los centros educativos, habiendo concurrido a establecimientos educativos gratuitos en la localidad. Pese a esto, observan una deficiencia importante en referencia al desarrollo de actividades deportivas, manifestando no desarrollar actividades en estos centros debido, en principio, a la falta de establecimientos y, en segunda instancia, a la limitada oferta en relación a las actividades de las que pueden participar. Similares limitaciones se perciben en relación a la oferta de actividades culturales y centros para el desarrollo de las mismas. Acerca del acceso a la salud, los encuestados residentes en áreas correspondientes a esta categoría refieren, en general, trasladarse a centros de atención fuera de la localidad de Punta Lara.

Contrastando, las encuestas realizadas a población residente en áreas correspondientes a la categoría B dieron cuenta de situaciones variadas. En términos generales, la mayor parte de los habitantes refirió poseer un acceso regular a los espacios verdes/públicos, como espacios de socialización y disfrute recreativo concurriendo con amigos y familia; con percepciones más cercanas al análisis cuantitativo de este indicador. Con respecto al acceso a la educación y salud, la percepción de la población difiere considerablemente del análisis cuantitativo. Mientras que este último indica una mayor cobertura de centros educativos y de salud, la mayor parte de los encuestados refiere trasladarse para satisfacer estas necesidades.

En términos del acceso a centros y actividades culturales, ambos análisis coinciden en que se trata de un indicador que presenta limitaciones en la oferta y la satisfacción de esta demanda. Igualmente, en el acceso a centros deportivos y áreas que permitan el desarrollo de estas actividades -pese a presentar una cobertura adecuada en términos cuantitativos-, la mayor parte de la población refiere no desarrollar actividades en centros deportivos municipales, manifestando la necesidad de construir mayor cantidad de establecimientos de este tipo en la localidad.

La categoría A presenta similitudes en ambos análisis, tratándose de las áreas con mejores coberturas de los diferentes indicadores, cuantitativamente; y con habitantes que refieren hacer uso de los espacios verdes/públicos, considerándolos como espacios que dan respuesta a sus necesidades. Además, manifiestan haber concurrido o concurrir a establecimientos educativos en la localidad, con diferentes opiniones acerca de la condición de los mismos. Por el contrario, los aspectos en los que la visión de la población difiere sustancialmente del análisis cuantitativo son el acceso a centros de salud, a centros educativos y a centros culturales, trasladándose a otras localidades para la satisfacción de estas necesidades. 


\section{C| Síntesis de la variable Ciudad Incluyente}

La variable ciudad incluyente contemplaba como parte de sus objetivos el generar una ciudad que fortaleciera la convivencia social de sus ciudadanos, así como las funciones recreativas, culturales y lúdicas de los espacios públicos; promoviendo la generación y mejoramiento de estos espacios y de centros públicos que permitan, además, el acceso a la salud y educación.

En esta línea, la población encuestada coincidió, en términos globales, en indicar como favorable el acceso a espacios verdes públicos fomentando y enriqueciendo la convivencia social y mixtura no sólo al interior de la localidad, sino también con población proveniente de otros sectores. Sin embargo, en coincidencia con el análisis cuantitativo -tanto de los indicadores individualmente como de la variable ciudad incluyente de forma integrada-, manifiestan cierta insatisfacción con respecto a la distribución de este tipo de espacios, debido a que se encuentran concentrados sobre el borde costero.

Nuevamente, pese a que se indica la importancia del borde costero -no sólo por los espacios y servicios que provee sino además por lo que genera a nivel identitario-, en términos del acceso a la ciudad la localidad presenta ciertas limitaciones a la hora de proveer de espacios de una forma distribuida y regular para todos los habitantes.

Otro aspecto relevante y constituyente del fomento de la convivencia social refiere también a la posibilidad de expresar libremente ideas y profesar la religión. Por este motivo, pudo reconocerse que, pese a que cualitativamente fueron relativas las respuestas obtenidas, cuantitativamente existe una diversidad de centros religiosos en la localidad que permite acercarse a la concreción de estos derechos asociados a la variable. Conjuntamente, en relación a la función lúdica y cultural que debiera garantizarse para una ciudad incluyente, la población encuestada recalcó la importancia de las actividades culturales que se desarrollan en la localidad así como aquellos espacios que generan un atractivo asociado a la cultura local (hitos/lugares identitarios).

Sin embargo, con respecto a la existencia dentro de la localidad de centros de acceso gratuito que les permiten satisfacer necesidades básicas de este tipo (como son el desarrollo de actividades recreativas, deportivas, culturales, entre otras), expresaron como importante la posibilidad de contar con mayor cantidad de espacios, en combinación con lo que pudo observarse en el análisis cuantitativo; situación que genera que la población se traslade para la satisfacción de estas necesidades.

En coincidencia con este último punto, los centros deportivos de la localidad también resultan escasos para la satisfacción de las necesidades, en función de satisfacer la función recreativa que las ciudades debieran contemplar; observándose una necesidad no resuelta en el territorio de la localidad.

En relación al acceso a la salud y a la educación como par inseparable, ambos indicadores presentaron deficiencias, tanto en términos cuantitativos como cualitativos, dando cuenta de que, pese a la existencia de este tipo de centros gratuitos resultan, en ocasiones, insuficientes; escenario frente al cual una parte importante de la población prefiere trasladarse a centros por fuera de la localidad, afectando la posibilidad de alcanzar estos derechos en su lugar de residencia, en detrimento de la satisfacción del derecho a la ciudad incluyente. 


\section{3| Consideraciones Generales}

A modo exploratorio -y complementando el análisis desarrollado-, se describen una serie de articulaciones y relaciones que pueden establecerse entre la variable ciudad incluyente y las restantes variables definidas.

Una de las interacciones más evidentes y directas que puede establecerse es con la variable ciudad accesible, particularmente a partir del indicador de movilidad urbana. Como fuera analizado previamente, principalmente a partir de la visión de la población encuestada, las cuestiones asociadas a la movilidad y las relaciones que se establecen con otras localidades del partido, e incluso con partidos aledaños (particularmente con la Plata), resultan fundamentales para la satisfacción de necesidades y derechos asociados al derecho a la ciudad que, en ocasiones, la población no puede alcanzar dentro de su territorio de referencia, debido; por la escala, magnitud que posee y el estar inserto en una estructura urbanaterritorial mayor, entre otras cuestiones.

En este sentido, resulta indispensable el acceso a un transporte público adecuado y accesible que permita el desplazamiento a otras localidades y regiones en tiempos relativamente cortos; complementariamente, la existencia de vías de circulación en condiciones para el transporte público y privado, que permita establecer estas interacciones. Así, se establece una relación positiva entre ambas variables, entendiendo que las mejoras sobre una de ellas generarán progresos sobre la siguiente, acercando cada vez más a los ciudadanos a la satisfacción del derecho a la ciudad.

Los restantes indicadores correspondientes a la variable ciudad accesible (Infraestructuras de Servicios y Desarrollo Social), resultan complementarios de la variable ciudad incluyente, pudiendo asociarse a esta última para alcanzar mejores condiciones en términos de una ciudad integradora, tendiendo, en principio, al acceso al suelo en un territorio apto y, en segunda instancia, a una vivienda en condiciones dignas con una infraestructura eficiente de servicios y que ofrezca condiciones adecuadas para el habitar.

En esta línea, otra de las articulaciones directas que pueden observarse entre la variable ciudad accesible y ciudad integradora es a partir de la dimensión infraestructura de servicios, asociada a la dimensión de vivienda; entendiendo que una de las condiciones fundamentales que las viviendas deberían presentar en pos de alcanzar la satisfacción del derecho a la ciudad, es el acceso a los servicios básicos (agua, electricidad, cloacas, entre otros). De esta forma, valores altos o adecuados en la dimensión infraestructura de servicios generará mejores condiciones sobre la variable ciudad integradora, particularmente sobre la dimensión de vivienda. Nuevamente, esta última dimensión es una de las que puede encontrar mayor cantidad de articulaciones con las restantes y, por ende, con otras variables, entendiendo el acceso a una vivienda y al hábitat en un entorno adecuado e integrado como uno de los principales factores a considerar en el derecho a la ciudad.

Además, resulta fundamental estudiar complementariamente la dimensión vivienda (ciudad integradora) con aquellas dimensiones relacionadas a la ciudad incluyente, entendiendo que -como fuera explicitado en el marco teórico en el que se apoya la presente investigación- garantizar el derecho a la ciudad implica no sólo el acceso al suelo y a una vivienda, sino que se deben dar condiciones que permitan también el habitar, con un entorno que permita acceder a centros de salud, al desarrollo de actividades deportivas y recreativas, a la educación y a la profesión del culto libremente.

A modo de ejemplo, la observación directa y el recorrido del área de estudio permitió reconocer el desarrollo de obras para prevenir los efectos que generan las condiciones naturales del territorio de la localidad, sobre el que se asientan gran cantidad de viviendas, particularmente debido a los efectos que se generan por su condición de localidad costera (inundaciones por Sudestada).

Esta última cuestión encuentra una relación directa con la variable ciudad sostenible, particularmente en el análisis de la dimensión Riesgos Ambientales. Así, debieran contemplarse todos estos factores para 
evaluar el grado de satisfacción del derecho a la ciudad, haciendo hincapié en cada una de estas variables y dimensiones complementariamente.

De igual mudo, en el marco de la variable ciudad sostenible, la dimensión asociada a la idea de ciudad encuentra articulación con las restantes variables (ciudad integradora, ciudad incluyente y ciudad accesible), debido a que esta "idea de ciudad" debiera ser el lineamiento sobre el cual se apoyen todas las decisiones en pos de alcanzar una mejor calidad de vida de cada uno de los habitantes, que permita, en consecuencia, acercarse a la satisfacción del derecho a la ciudad.

Otra de los diálogos que puede establecerse entre la variable ciudad incluyente y ciudad integradora se encuentra en la articulación entre la dimensión educación y la dimensión de formación profesional correspondientes a cada una de estas variables respectivamente- entendiendo que es necesario el acceso a las distintas instancias educativas que permitan la formación de los ciudadanos y, más aún, la formación de profesionales que puedan acceder a un trabajo de calidad, particularmente teniendo en cuenta el mundo globalizado en el que nos encontramos en la actualidad, que requiere de una formación que excede la educación primaria y secundaria.

Precisamente, como pudo observarse en el análisis del indicador de centros educativos, el área de estudio ofrece la posibilidad de acceder a centros de formación pública en sus distintas instancias (inicial, primaria y secundaria), pero la oferta de centros de formación profesional se encuentra concentrada en las restantes localidades que conforman el partido, tanto Ensenada como El Dique ${ }^{23}$ e incluso en partidos aledaños, como La Plata, que además ofrece la posibilidad del acceso a formación universitaria.

Las dimensiones e indicadores definidos para la variable ciudad democrática (Organización Social, Participación de la Sociedad e Información Pública) conducen a estudiarla de forma transversal a las restantes variables. Así, debiera interpretarse como una variable con características independientes pero de necesaria articulación con las restantes, entendiendo que garantizar el acceso a la información pública, la organización de la sociedad y la participación social, resultan herramientas fundamentales para que los ciudadanos puedan adquirir conocimientos que les permitan exigir mejoras y condiciones necesarias para la satisfacción del derecho a la ciudad.

En conclusión, estos breves ejemplos muestran algunas de las relaciones que se pueden y deben establecer entre las diferentes variables, siempre considerando los contextos particulares de aplicación de la metodología, entendiendo la complejidad del concepto del derecho a la ciudad y, principalmente, la integralidad que implica su estudio (Figura 71).

\footnotetext{
${ }^{23}$ Dirección General de Cultura y Educación (2019). Disponible en: http://mapaescolar.abc.gob.ar/mapaescolar/
} 


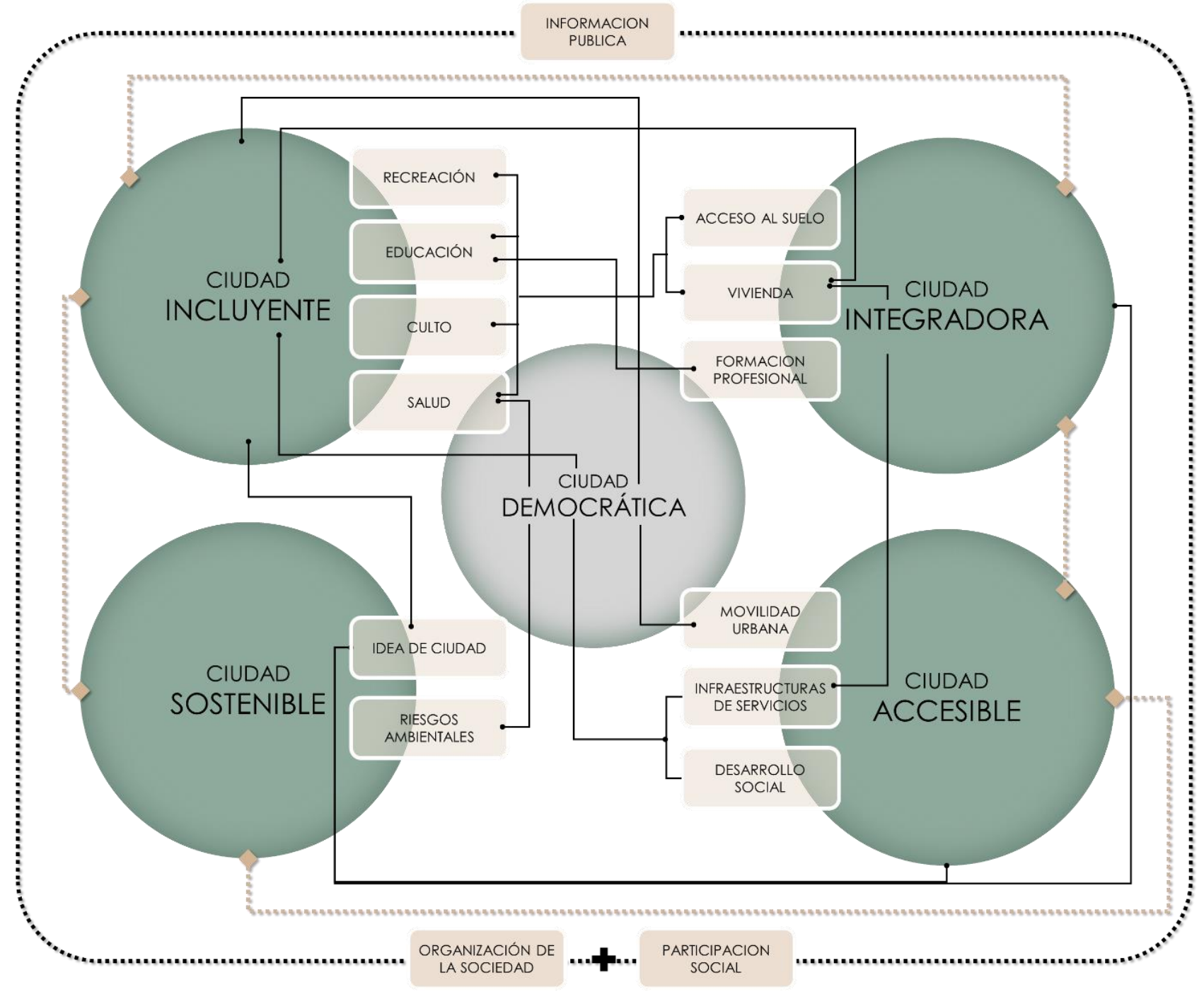

Figura 71. Relaciones entre variables y dimensiones. Elaboración propia. 2019 
CIERRES Y

APERTURAS 


\section{| CIERRES Y APERTURAS}

En este último apartado de cierres y aperturas, se recuperan los objetivos e hipótesis formulados al inicio del trabajo, describiendo tanto los resultados principales alcanzados en el marco de cada uno de ellos, como los desafíos que se presentaron en su desarrollo; y aquellos aspectos que permiten dar continuidad al desarrollo del trabajo en futuras investigaciones.

\section{A | Sobre el derecho a la ciudad como enfoque}

El primer objetivo propuesto para el desarrollo de la presente tesis se planteó la indagación acerca del derecho a la ciudad como enfoque emergente, procurando contribuir a la conformación de un marco teórico en relación a este concepto, que ha tenido una amplia difusión, particularmente en los últimos años. Con esto presente, los interrogantes que se esbozaron y a los cuales se respondió en el primer y segundo capítulo de la tesis, se enfocaron en la existencia de antecedentes teóricos y metodológicos en relación al derecho a la ciudad, en el aporte que generaría el evaluar este derecho en un territorio y en el porqué de buscar el desarrollo de una metodología a estos fines.

A partir de estos interrogantes, fueron numerosos los antecedentes teóricos que pudieron reconocerse, particularmente relacionados con el proceso de construcción de este concepto a lo largo de los años; complementarios unos de otros, pero con visiones que enfatizan diferentes cuestiones. De esta forma, pudo observarse cómo los primeros antecedentes procuraban lentamente superar la concepción de derechos exclusivamente relacionados a la vivienda, incorporando aspectos relativos al habitar; como, por ejemplo, la Ley 388/97 de la República de Colombia del año 1997, la Carta Europea de Salvaguarda de los Derechos Humanos en la Ciudad del año 2000, o el Estatuto de la Ciudad de Brasil, del año 2001. Además, en el marco del contexto en el cual se desarrolla la investigación, se estudió uno de los primeros instrumentos relevantes en torno a este derecho en Argentina, la Ley de Acceso Justo al Hábitat, que da cuenta de la necesidad de garantizar este derecho, repensando y complementando algunos de los instrumentos que existían hasta el momento (como el Decreto-Ley 8912/77).

De esta manera, las cartas y declaraciones comienzan a plantear que "tener derecho a la ciudad" es mucho más que simplemente acceder a un techo y a ciertos servicios básicos que hacen a la vida en la ciudad (acceso al servicio de agua, de desagües cloacales, de iluminación, etc.) y que deben incorporarse derechos relacionados a la educación, la salud, la cultura; dando lugar a una vida en ciudad de mejor calidad, que permita la realización plena de cada uno de los ciudadanos que la habitan.

Este recorrido dio cuenta, en principio, de la complejidad del derecho a la ciudad, que se ve reflejada en la cantidad de derechos que se encuentran contemplados dentro del mismo; y de la necesidad de incorporarlo como una herramienta que permita mejorar la calidad de vida de la población. Por este motivo, cada una de estas declaraciones e instrumentos fueron fundamentales para el desarrollo posterior de la metodología y la definición de los aspectos que debieran considerarse para analizar el grado de cumplimiento de este derecho en un territorio.

Complementando las visiones teóricas, se estudiaron ejemplos metodológicos relacionados con el análisis de este derecho, y otros aspectos asociados -pese a no tratarse específicamente de estudios acerca del derecho a la ciudad-. Esta búsqueda demostró las limitaciones que existen en términos de instrumentos metodológicos, tanto de implementación como de conocimiento acerca del grado de satisfacción de este derecho. Sin embargo, se recalca que los antecedentes analizados resultaron de gran importancia para comenzar a recorrer el camino que este desafío de construir una metodología de análisis planteaba. 
En esta línea, se valoró principalmente el trabajo desarrollado por Fernando Murillo y Mariana Schweitzer (2010) "La planificación urbana habitacional y el derecho a la ciudad. Entre el accionar del estado, el mercado y la informalidad" debido a que, a partir de la definición de indicadores y variables que se derivan del derecho a la ciudad, estudia una serie de casos testigos, desarrollando una metodología para este fin.

Una vez avanzado el recorrido de los antecedentes teóricos y metodológicos, se realizaron las precisiones conceptuales en torno a este enfoque que, como ya fuera dicho, resultaba complejo en términos de su comprensión, articulándolo a otras nociones fundamentales que definieron la línea conceptual sobre la que se basó la presente investigación.

En este marco, la primera asociación realizada permitió estudiar al derecho a la ciudad en conjunto con el territorio, entendiendo que este último constituye un espacio social cada vez más urbano, que integra a una multiplicidad de actores e intereses; y que estos actores tienen un "proyecto" para el territorio que conduce a construirlo, a discutir sobre él y a la definición de objetivos y metas. Así, se asoció esta idea al concepto de ciudad, como conjunción de urbs, civis y polis; y, esencialmente, a la ciudad como espacio de concreción de derechos, de estos objetivos y metas que se definen y que buscan garantizar una mejor calidad de vida para los ciudadanos. En este punto, empezó a darse forma al derecho a la ciudad como algo más que un simple techo para vivir, asociándolo al concepto de "hábitat", definiéndolo como el usufructo equitativo de las ciudades, contemplando los principios de sustentabilidad y justicia social; constituyéndose así en un derecho que excede las individualidades y se enfoca en la satisfacción de derechos colectivos que hacen al habitar de todos los ciudadanos.

Sin embargo, muchas de las cartas y documentos estudiados en relación al derecho a la ciudad se convirtieron en declaraciones que no derivaron en instrumentos específicos que permitieran evaluar y, a partir de esto, diseñar y ejecutar políticas públicas que favorezcan la satisfacción de este derecho. Estas manifestaciones nos condujeron a reflexionar acerca de la posibilidad de pensar en el estudio y la aplicación del derecho a la ciudad, incluso en los contextos actuales caracterizados por las desigualdades sociales, económicas, políticas, culturales; con ideas de ganancia y usufructos individuales por encima de ideas asociadas a garantizar el bienestar colectivo.

Como conclusión, los aportes de la presente investigación pueden observarse en la reafirmación de la complejidad del derecho a la ciudad, que contiene una multiplicidad de derechos y aporta elementos superadores en relación a la comprensión de un territorio y las necesidades de la sociedad que lo habita.

Por este motivo, resultaba un desafío importante, y un aporte relevante, el plantear un camino que permitiera desarrollar una herramienta metodológica, como punto de partida para evaluar el grado de concreción actual de este derecho en el territorio y, a partir de generar conocimiento, empezar a pensar en acciones que permitan concretar ciudades más justas en términos sociales y espaciales.

\section{B | Sobre el derecho a la ciudad como "herramienta"}

Cuando esta tesis decidió enfocarse en una primera aproximación a la construcción de una herramienta metodológica que permitiera hacer operativo el derecho a la ciudad, resultó fundamental definir de qué manera desarrollarlo. Así, estudiando antecedentes metodológicos, se observó como factor recurrente la construcción de indicadores, dimensiones y variables para descomponer el concepto que se deseaba evaluar. Por este motivo, otro de los objetivos propuestos fue el de determinar y caracterizar las variables que definen al derecho a la ciudad y también los indicadores para cada una de ellas, de modo de poder abordarlo desde una perspectiva metodológica. 
Se estima que el aporte más significativo de esta tesis estuvo entonces, desde lo metodológico, en la traducción de cada uno de los principios del derecho a la ciudad analizados en el recorrido teórico, en variables que pudieran ser abarcadas desde un territorio específico -que, como tal, posee características y dinámicas particulares-. Así, el ejercicio pleno de la ciudadanía y la gestión democrática de la ciudad, se tradujo en la variable Ciudad Democrática; la promoción del acceso a los servicios básicos, en Ciudad Accesible; la igualdad entre todos los habitantes, en Ciudad Integradora; el respeto por el medio ambiente, en Ciudad Sostenible; y, finalmente, el usufructo equitativo de las ciudades en la variable Ciudad Incluyente.

Con estos factores presentes, y dimensionando la complejidad del abordaje del derecho a la ciudad, se propusieron una serie de condiciones que permitieron el análisis desde una mirada de arquitecto urbanista. Así, se desarrolló el análisis a partir de una articulación de técnicas cuantitativas interpeladas mediante la aplicación de técnicas cualitativas, que permitiera su estudio desde la experticia de un arquitecto con formación en Ciencias del Territorio; pudiendo traducirse esta información en mapas, procurando incorporar indicadores complejos de manera sencilla.

En este marco, otro de los aportes en términos metodológicos estuvo ligado al alcance de resultados asociados, contemplando una multiplicidad de indicadores relacionados y ponderados; entendiendo que, en este análisis del grado de satisfacción del derecho a la ciudad en un territorio, todos los derechos deben garantizarse de igual modo, pero existen diferencias que permiten ponderar la urgencia de satisfacer cada uno de ellos. Así, la posibilidad de contar con información sistematizada de la realidad y la vivencialidad de los habitantes, permite acercarse a diagnósticos más acertados y al conocimiento del grado de satisfacción de derechos en un territorio.

En síntesis, pese a que muchas veces el derecho a la ciudad parece utilizarse simplemente como una declaración compleja de aspectos que deben satisfacerse, más que como una herramienta concreta, a partir del desarrollo de esta tesis pudo observarse que la descomposición en variables e indicadores permite iniciar un camino hacia la construcción de un instrumento metodológico que puede incorporarse para evaluar un territorio, como sistema de soporte para desarrollar propuestas sobre la planificación de un territorio en torno a esta evaluación. En este sentido, se considera que el aporte realizado por esta tesis puede constituir una fase inicial que, seguramente, será enriquecida con la mirada de otros especialistas.

\section{C | Sobre la aplicación metodológica de la herramienta. Variable Ciudad Incluyente}

La hipótesis principal que se planteó como motor de la presente tesis recalcaba que "el desarrollo de una metodología que operacionalice el enfoque del derecho a la ciudad, permitirá aportar al conocimiento del grado de satisfacción de este derecho en un recorte de la localidad de Punta Lara -y a partir de una variable específica-, constituyendo un insumo para la toma de decisiones y la implementación de políticas y estrategias de intervención".

Contrastando esta hipótesis con los resultados empíricos alcanzados en el desarrollo de la presente investigación, pudo comprobarse -pese a las limitaciones propias del desarrollo de una tesis individual en el marco de una maestría-, que es posible la aplicación de una metodología para conocer y estudiar un territorio desde el enfoque del derecho a la ciudad.

En particular, en relación al caso analizado, pudo reconocerse que el abordaje a partir de la herramienta, la espacialización de los resultados y la posterior interpelación con la visión y percepción de los habitantes de la localidad, hicieron visibles situaciones particulares y diferenciadas. 
Así, por ejemplo, pese a que el estudio inicial de los espacios verdes daba cuenta de la existencia de una variedad importante y una superficie adecuada para la totalidad de la población, esta cobertura no era continua y los espacios presentaban diferentes grados de consolidación, generando una disminución en el acceso real de la población a los espacios verdes públicos. Además, analizando los mapas de cada uno de los indicadores comparativamente, se observó en general una concentración de los equipamientos (deportivos, culturales, educativos) en el borde costero de la localidad, enfatizando nuevamente que el acceso real de la población a estos equipamientos y, por ende, la satisfacción de estos derechos, era relativa.

La aplicación de una de las variables construidas como parte de la metodología, en el caso testigo de la localidad de Punta Lara, permitió estimar que puede tratarse de una herramienta que, cuantitativamente, podría aplicarse en otro contexto (previa actualización a factores o condicionantes que no fueran contemplados en este caso por las características particulares del área adoptada); pero contemplando, además, la importancia de la consideración del hombre como parte constituyente del territorio, retomando a Lefevbre quien sostenía que todos somos "seres urbanos".

En este caso, a partir de la aplicación cuantitativa de los indicadores fue posible conocer un territorio desde un enfoque complejo como es el derecho a la ciudad, interpelando estos datos cuantitativos a partir de opiniones y vivencias de la población de la localidad, incorporando sus propias visiones y dinámicas al análisis. A partir de esta doble articulación, se obtuvieron resultados que enriquecieron la interpretación realizada de cada uno de los indicadores, que podrían significar un punto de partida para el desarrollo de políticas que permitan garantizar, en principio, el derecho a una ciudad incluyente y, en conjunción, el derecho a la ciudad.

\section{D | Continuidades y aperturas}

Los resultados obtenidos a partir del desarrollo de la presente tesis conducen al planteo de nuevos interrogantes y aplicaciones en investigaciones futuras. Como ya fuera dicho, la tesis presentada avanza en el desarrollo de una de las variables de la herramienta construida para valorar el grado de concreción del derecho a la ciudad en un territorio, apoyados en los conocimientos adquiridos durante el proceso de formación en Ciencias del Territorio. Así, se estima profundizar en futuras investigaciones (tesis doctoral) en el abordaje de otras variables, a fin de poder estudiar y aplicar en un caso testigo el índice de derecho a la ciudad aquí planteado.

En relación a los aportes conceptuales, pudo concluirse que, si bien existen numerosas cartas y declaraciones que urgen a considerar el derecho a la ciudad como un derecho fundamental que debe satisfacerse y garantizarse, el solo hecho de manifestar esta necesidad no genera una resolución automática de la misma. Así, el reto se encuentra en llevar los debates y discusiones más allá de los aspectos teóricos, resultando cada vez más necesaria la generación de herramientas e instrumentos que estudien y analicen en principio esta necesidad y las características principales de los territorios en relación a este derecho, y que permitan luego concretarla a partir de la aplicación de los mismos.

A modo de conclusión general, la iniciativa de iniciar el camino para la construcción de una metodología que permita hacer operativo el enfoque del derecho a la ciudad para el análisis del grado de cumplimiento del mismo en un territorio específico, resulta de interés tanto para aportar al conocimiento de este enfoque complejo, como para generar una herramienta que permita avanzar en la gestión integral de los territorios garantizando la extensión de cada vez más derechos a más grupos. Se entiende como una apuesta ambiciosa y desafiante, que se enmarca en la postura superadora del derecho a la ciudad como enfoque contemporáneo, que va más allá de la mera construcción y evaluación de indicadores aislados. 
Ante este panorama es que, como manifiestan Blanco y Gurevich (2002) "es necesario abordar los nuevos escenarios urbanos con miradas más abarcativas, preguntas más complejas e instrumentos más finos", e incorporar el derecho a la ciudad como un enfoque y una herramienta para actuar frente a las problemáticas asociadas a un mundo cada vez más urbanizado, generando nuevos modelos urbanos que permitan mejorar la calidad de vida de la población.

En este sentido, es oportuno expresar que la presente investigación permite iniciar el camino hacia la construcción de una metodología que permita operacionalizar este enfoque y, eventualmente, traducirse en acciones, estrategias y políticas que avancen en la construcción de conocimiento acerca de las ciudades y la sociedad que los habita, evolucionando hacia ciudades más democráticas y justas.

A modo de cierre...

"...el derecho a la ciudad, en tanto agenda política y programática, ofrece instrumentos concretos para remodelar nuestros asentamientos humanos como bienes comunes y creaciones colectivas"

Lorena Zarate (2017) 
BIBLIOGRAFÍA 


\section{BIBLIOGRAFÍA}

Argentina. Ministerio de Justicia y Derechos Humanos. Secretaría de Derechos Humanos (2011). Derecho a la ciudad: por una ciudad para todas y todos. Ideas para debatir. Coordinado por María Cristina Perceval y Jordana Timerman. Buenos Aires: Secretaría de Derechos Humanos del Ministerio de Justicia y Derechos Humanos de la Nación.

Argentina. Dirección Provincial de Ordenamiento Urbano y Territorial. Dirección de Planificación Urbana y Territorial. (2009). Plan Estratégico Territorial. Buenos Aires: Subsecretaría de Urbanismo y Vivienda.

Argentina. Dirección Provincial de Ordenamiento Urbano y Territorial de Buenos Aires (2011). Sistemas de Información Geográfica para el ordenamiento territorial. Obtenido el 15 de enero de 2018 de http://www.mosp.gba.gov.ar/sitios/urbanoter/sig/Manual_SIG_UT.pdf

Barrera G., A. (Coord.), Suárez Bultrón, G., Olmedo, P. (2017). Derecho a la ciudad, participación ciudadana y presupuestos participativos (2 edición). Quito: FES-ILDIS

Blanco, J. y Gurevich, R. (2002). Una geografía de las ciudades contemporáneas. En Alderoqui, S. y Pompi Penchansky (Comp). Ciudad y ciudadanos. Aportes para la enseñanza de un mundo urbano. Buenos Aires: Editorial Paidós.

Borja, J. (2014). Revolución urbana y derechos ciudadanos (1ºdición). Buenos Aires: Café de las Ciudades.

Borja, J. (2012). El fin de la anticiudad posmodernista y el derecho a la ciudad en las regiones metropolitanas. En Belil, M. (Ed.) Ciudades, una ecuación imposible (pp. 279-320). Buenos Aires: Editorial Café de las Ciudades.

Buzai, G. (2010). Análisis Espacial con Sistemas de Información Geográfica: sus cinco conceptos fundamentales. En Buzai, G.D. (Ed.) Geografía y Sistemas de Información Geográfica. Aspectos conceptuales y aplicaciones (pp.163-195). Luján: Universidad Nacional de Luján. GESIG.

Caicedo, J. M. (2007). La Ley 388 de 1997. Un repaso a una década. Trabajo presentado en Seminario 10 años de la ley 388 de 1997: sus aportes al ordenamiento urbano y a la consolidación de políticas de suelo, Bogotá.

Carrión, F.; Erazo, J. (2016). El derecho a la ciudad en América Latina: visiones desde la política. Obtenido el 14 de enero de 2017 de http://puec.unam.mx/pdf/libros_digitales/el_derecho_a_la_ciudad_digital.pdf

Celemin, J. P.; Mikkelsen, C. A.; Velázquez, G. A. (2015). La calidad de vida desde una perspectiva geográfica: integración de indicadores objetivos y subjetivos. Revista Universitaria de Geografía, 24, 6384.

Chardón, A. (2010). Reasentar un hábitat vulnerable. Teoría versus praxis. Revista INVI, 25(70).

Comisión Económica Para América Latina y el Caribe. CEPAL (2012). Población, territorio y desarrollo sostenible. Santiago de Chile: Naciones Unidas.

Corboz, A. (2004). El territorio como palimpsesto. En Ramos, A.M (Coord.) Lo urbano en 20 autores contemporáneos (pp. 25-34). Barcelona: Editorial UPC.

Correa Montoya, L. (2010). Algunas reflexiones y posibilidades del Derecho a la Ciudad en Colombia: Los retos de la igualdad, la participación y el goce de los derechos humanos en los contextos urbanos. Revista Jurídica de la Universidad de Palermo, 1, 31-74. 
Fernández, E. (2014). La construcción del "Derecho a la Ciudad" en Brasil. Obtenido en septiembre de 2017, de https://derechoalaciudadflacso.files.wordpress.com/2014/01/edesio-fernandes-la-construcciondel-derecho-a-la-ciudad-en-brasil.pdf

Fernández Wagner, R. (2014). Las políticas habitacionales en la ciudad injusta. Revista Vivienda Popular, 25, 34-45.

Harvey, D. (2008). El derecho a la ciudad. Obtenido el 13 de julio de 2015, de http://www.fadu.uba.ar/mail/difusion_extension/090522_bol.pdf

Harvey, D. (2012). Ciudades rebeldes. Del derecho a la ciudad a la revolución urbana. Madrid: Editorial Akai.

Hernández Sampieri, R.; Fernández Collado, C; Baptista Lucio, P. (2010). Metodología de la investigación (5ta Edición). México. Editorial McGRAW-HILL / INTERAMERICANA.

Instituto Pólis (2014). Comprender e implementar el derecho a ciudad, construyendo ciudades justas, democráticas y sostenibles. Obtenido el 15 de marzo de 2016, de http://www.hicgs.org/document.php?pid $=5453$

Jacobs, J. (2011). Muerte y Vida de las grandes ciudades (1 Edición). Madrid: Editorial Capitán Swing.

Jaramillo, S. (2003). Los fundamentos económicos de la participación en plusvalías. Bogotá: CIDE Universidad de los Andes y el Lincoln Institute of Land Policy.

Lefebvre, H. (2017). El derecho a la ciudad. Madrid: Editorial Capitán Swing.

López, I. (2003). Ciudad, planificación y calidad de vida. Documento de Cátedra, Planeamiento Físico N 1. Bono-Laurelli-López. FAU-UNLP. Argentina

Marradi, A; Archenti, N.; Piovani, J. (2007). Metodología de las Ciencias Sociales (1ºdición). Buenos Aires: Emecé Editores.

Mendez-Nuñez, Á; Murillo, F. J. (2017). Reivindicando la Labor Intelectual y Transformativa del Profesorado en una Educación para la Justicia Social. Revista Internacional de Educación para la Justicia Social (RIEJS), 383-399.

Mochón, F.; Beker, V. (1997) Economía. Principios y aplicaciones (2 Edición). Madrid: McGrawHill/Interamericana de España.

Murillo, F., Schweitzer, M. (2010). La planificación urbana-habitacional y el derecho a la ciudad. Entre el accionar del Estado, el mercado y la informalidad (1 edición). Buenos Aires: Editorial Cuentahilos.

Nuñez, A. (2010). Los sin techo. Una experiencia de lucha por la vivienda, en Mar del Plata. Obtenido en junio de 2018, de http://base.d-p-h.info/en/fiches/dph/fiche-dph-8494.html\#Haut.

Ortiz Flores, E. (2006). Hacia una Carta Mundial por el Derecho a la Ciudad. México: Coalición Internacional para el Hábitat. Oficina Regional para América Latina.

Oszlack, O., O'Donnell, G. (1981). Estado y políticas estatales en América Latina: hacia una estrategia de investigación. Buenos Aires: Centro de Estudios de Estado y Sociedad (CEDES).

Pirez, P. (1995). Actores sociales y gestión de la ciudad. CIUDADES 28. México: RNIU.

Ramos, Á. M. (2004). Lo urbano en 20 autores contemporáneos. Barcelona: Editorial UPC. 
Rodríguez Barrientos, F. (2007). La microrregión como unidad espacial para el estudio de los problemas ambientales. Situación de los recursos suelo, forestal e hídrico en la microrregión Platanar-La Vieja, cuenca del río San Carlos. Revista Tecnología en Marcha, 20, 62-79.

Rolnik, R. (2001). El Estatuto de La Ciudad. Nuevas herramientas para garantizar el derecho a la ciudad. Editado por Instituto Polis. Obtenido de http://www.polis.org.br

Rolnik, R. (2011). Informe de la relatora especial sobre una vivienda adecuada como elemento integrante del derecho a un nivel de vida adecuado, y sobre el derecho a la no discriminación en este contexto. Naciones Unidas, Asamblea General. Obtenido de http://acnudh.org/wpcontent/uploads/2012/03/Informe-Relatora-sobre-vivienda-adecuada-misi\%C3\%B3n-a-Argentina2011.pdf

Sánchez, Anna. (s/f). Del derecho a la vivienda al derecho a la ciudad. Observatorio Derechos Económicos, Sociales y Culturales. Obtenido el 16 de agosto de 2014, de http://observatoridesc.org/files/cap7.pdf

Speck, J. (2013). Walkable city: how downtown can sabe America, one step at a time. Nueva York: Editorial Farrar, Strauss an Giroux.

Sugranyes, A., Mathivet, C. (2010). Ciudades para todos. Por el derecho a la ciudad, propuestas y experiencias ( $2^{\circ}$ Edición). Santiago de Chile: Habitat International Coalition (HIC).

Tomadoni, C. (2007). A propósito de las nociones de espacio y territorio. Trabajo presentado en Conferencia Territorio y ambiente: una mirada geográfica en el Il Encuentro Internacional sobre Pensamiento Ambiental, Colombia.

Zárate, L. (2017). ¿Cuarenta años no son nada? La Lucha por la inclusión del derecho a la ciudad en la agenda global. En Olmedo M., P., Endara, G. (Eds.) Alternativas urbanas y sujetos de transformación (pp. 350-397). Quito: FES-ILDIS. Obtenido de http://library.fes.de/pdf-files/bueros/quito/13867.pdf

\section{CARTAS}

Carta Europea de Salvaguarda de los Derechos Humanos en la Ciudad (2000). Comisión de Inclusión Social, Democracia Participativa y Derechos Humanos de CGLU.

Carta Mundial del Derecho a la Ciudad (2005)

Carta de Derechos y Responsabilidades de Montreal (2006)

Carta de la ciudad de México por el derecho a la ciudad (2009)

Carta-Agenda Mundial de Derechos Humanos en la Ciudad (2011)

\section{LEYES CONSULTADAS}

Ley No 388 (1997). Colombia.

Ley No 14.449: Ley de Acceso Justo al Hábitat (2012). Buenos Aires, Argentina.

Ley N ${ }^{\circ}$ 10.257. Estatuto de la Ciudad (2001). Brasil.

Ley N²4.430. Constitución de la Nación Argentina (1994). Argentina

Constitución de la República de Ecuador (2008). Ecuador

Constitución de la Provincia de Buenos Aires (1994). Argentina 
ANEXOS 


\section{ANEXO I | Cuestionario Encuestas}

DATOS

¿Cuál es su edad?

¿Adónde vive?

¿Siempre vivió acá? O ¿Cuánto hace que vive acá?

\section{INDICADOR ESPACIOS VERDES/PÚBLICOS}

¿Hace uso de los espacios públicos de la localidad? (Plazas, parque costero, etc.)

$\square \quad$ Sí, voy REGULARMENTE con familia/amigos

$\square \quad$ Sí, voy SOLO A VECES con familia/amigos

$\square \quad$ No, PRACTICAMENTE NO HAGO USO de los espacios públicos

¿Cómo calificaría la calidad de estos espacios?

$\square \quad$ Buena

$\square \quad$ Regular

$\square \quad$ Mala

¿Considera que los espacios verdes públicos en la localidad de Punta Lara son suficientes?

$\square \quad$ Sí

$\square \quad$ No

\section{INDICADOR CENTROS DEPORTIVOS}

¿Desarrolla alguna actividad deportiva en los centros deportivos municipales?

Sí. ¿Podría indicar el nombre de la institución?

No

En general, ¿cómo calificaría la calidad de estos centros?

$$
\begin{aligned}
& \text { Buenos } \\
& \text { Regulares } \\
& \text { Malos }
\end{aligned}
$$

Si tuviera que proponer alguna mejora en relación al desarrollo del deporte en Punta Lara, consideraría

MEJORAR las instalaciones/centros deportivos existentes

Proveer MAYOR CANTIDAD DE SERVICIOS en los centros

CONSTRUIR MÁS CENTROS DEPORTIVOS gratuitos en la localidad (los existentes no son suficientes)

\section{INDICADOR CENTROS EDUCATIVOS}

¿Concurre/concurrió a centros educativos cercanos a su lugar de residencia, en la localidad de Punta Lara?

Sí. ¿Podría indicar el nombre de la institución?

$\square \quad$ No, me traslado/trasladé a centros educativos fuera de Punta Lara

En general, ¿cómo calificaría la condición edilicia de estos establecimientos?

$$
\begin{array}{ll}
\square \quad \text { Buenos } \\
\square \quad \text { Regulares } \\
\square \quad \text { Malos }
\end{array}
$$

¿Considera que los centros educativos en la localidad de Punta Lara son suficientes?

$$
\text { Sí }
$$




\section{INDICADOR CENTROS DE SALUD}

¿Cuándo tiene que recibir atención médica, lo hace en algún centro de salud PÚBLICA de Punta Lara? (Unidad Sanitaria, Hospital)

$\square \quad$ Sí

$\square \quad$ No, me traslado a centros de atención fuera de Punta Lara

En general, ¿cómo calificaría la calidad de las instalaciones (por ejemplo, espacio, áreas de espera y limpieza de los servicios de salud)?

Buenas

Regulares

Malas

\section{INDICADOR DE CENTROS CULTURALES}

¿Concurre a alguno de los centros culturales de la localidad de Punta Lara?

Sí. ¿Podría indicar el nombre?

No

¿Cómo los calificaría respecto a sus instalaciones/actividades?

- Buenos, tienen actividades interesantes y las instalaciones se encuentran en buenas condiciones

Regulares

Malos, no hay suficientes actividades, las instalaciones no son adecuadas, etc.

¿Podría mencionar dos o tres lugares representativos con los que se identifique a la localidad de Punta Lara?

\section{INDICADOR CENTROS RELIGIOSOS}

¿Asiste a Centros religiosos de la localidad de Punta Lara?

No, me traslado a centros fuera de la localidad 


\section{A CIUDAD}

\section{Punta Lara fue la escapada preferida ante el calor}

El balneario ensenadense fue elegido por vecinos de la Región y el Conurbano

\section{Q}

ANTE LAS ALTAS TEMPERATURAS, LOS VECINOS ELIGIERON PUNTA LARA PARA PASAR LA SOLEADA TARDE DEL SÁBADO

Con máximas que superaron los 33 grados en la tarde de ayer, mucha gente eligió escapar del calor de la Ciudad y refugiarse en las arenas de Punta Lara. Sombrillas, reposeras y mate hacen de las playas del Río de la Plata una opción de fin de semana.

Al igual que sucede en los lugares de la costa atlántica donde algunos eligen las playas céntricas y otros prefieren las más alejadas, en Punta Lara también hay para todos los gustos. Fue por eso que esta vez el recorrido no se hizo por la "playita", uno de los lugares referenciales de la costa riberense, sino en otra playa costera con una buena extensión de arena húmeda y formaciones de agua que genera el mismo río, donde la gente busca una mayor tranquilidad.

Una pareja de amigas de La Plata pasaron la tarde tomando sol en ese lugar, con mucho bronceador y el color del verano que se les notaba en la piel. Silvina y Nancy son aseguran que "hace muchísimos años que venimos a Punta Lara, antes íbamos a la playita pero ahora preferimos este lugar más tranquilo".

\section{PEDIDO}

Las mujeres son fieles asiduas a la costa ensenadense y es por eso que se animaron a reclamar por mejores condiciones de las playas que eligen para pasar las tardes durante casi toda la semana. "Ya hicimos la denuncia a la Dirección de Turismo porque el único problema que tenemos acá es la falta de higiene y para nosotras que venimos siempre es importante que lo solucionen" contó Silvina y reafirmó Nancy: "este lugar está bárbaro y es una pena que esté así, incluso dejamos de ir a la playita porque allá ni siquiera había baños".
En contraposición, una familia de Quilmes que también se encontraba en el lugar dijo: "a nosotros nos encanta venir porque nos alejamos de la muchedumbre, hay poca gente y el lugar está limpio a comparación del balneario de Quilmes". Marlene Sánchez afirmó: "venimos todos los fines de semana que podemos porque es cómodo, tenemos parrilla y nos gusta mucho el lugar para que jueguen los chicos".

Y si de juegos y niños se trata, un joven matrimonio platense también optó por la playa de Punta Lara "porque los chicos se meten al agua, juegan y la pasan bien, más que nada lo hacemos por ellos" señaló Carolina Aguila y agregó "no venimos muy seguido, incluso hoy por ayer- tengo que ir a trabajar, pero nos gusta porque como no tenemos vacaciones esto es lo más cercano y accesible para despejarse en pleno enero". 


\section{Punta Lara, la playa top del conurbano}

Aseguran que no hay contaminación en sus aguas

11 de enero de 2010

LA PLATA.- Sebastián Ojeda, de 18 años, supo del balneario Punta Lara por intermedio de un compañero de teatro. "La excursión hasta acá nos costó 25 pesos", dice el joven de González Catán, mientras juega a las cartas con tres amigos, sentado en la arena de esta playa de río, cercana a La Plata y perteneciente al partido de Ensenada, donde cada fin de semana llegan más de 100.000 personas.

Gonzalo llegó en un ómnibus escolar, en un viaje organizado por un particular que salió a las siete de la mañana de Merlo y que lo llevará de vuelta a casa cuando anochezca. Todos los sábados y los domingos del verano pueden verse, en los alrededores de la costa de Punta Lara, centenares de ómnibus que transportan gente de diferentes sitios del conurbano, como Moreno, Merlo, Morón, San Justo, Boulogne, Wilde o Burzaco.

El frente costero de Punta Lara abarca 18 kilómetros, de los cuales diez están habilitados para bañarse y ocho, para la práctica de pesca deportiva. En algunas zonas, se distinguen selvas en sus márgenes.

Algunos llegan con sus kayaks, motos de agua, semirrígidos, gomones, lanchas y veleros. Otros practican windsurf, esquí acuático o hasta se animan al kitesurf .

Asimismo, próximos a la costa, existen espacios de uso público y privado. A los primeros, se los distingue porque sus mesas, bancos y parrillas de hormigón están pintados de color verde. Los privados, en cambio, pertenecen a clubes, algunos de gremios y sindicatos.

"El primer fin de semana del año ingresaron más de 140.000 personas", aseguró Néstor Canutti, jefe de guardavidas de este lugar, 60 kilómetros al sur de la ciudad de Buenos Aires. A diferencia de los fines de semana, de lunes a viernes la concurrencia de público disminuye y proviene de otros lugares. Son, en su mayoría, vecinos locales, de La Plata, o residentes de zonas cercanas, como Berisso, quienes visitan esta playa que, cuando el río está bajo, puede alcanzar los 600 metros de ancho.

"En temporada, 1.500.00o de personas ingresan en la localidad de forma recreativa", afirmó el intendente de Ensenada, Mario Secco.
El director de turismo comunal, Adrián Espósito, explicó: "Por ser una de las playas de río de mayor extensión y por la apertura de senderos hacia la costa, que permite una mejor distribución de la gente, Punta Lara ha crecido año tras año en cantidad visitantes".

Dada la afluencia de gente y las características propias del Río de la Plata, de fondo arenoso o de barro, se estableció un equipo de 46 guardavidas municipales y otros veinte que corresponden a clubes privados.

"Es una alternativa buena, cercana y económica", opina Sebastián, antes de enfilar hacia el río para refrescarse. 

autoridades de la Dirección de Escuelas", explicaron los chicos.

A través de su Centro de Estudiantes

\section{Alumnos de la Media Nro 2 de Punta Lara piden un techo para su escuela}

En Punta Lara los alumnos de la Escuela Media $N^{\circ} 2$ hace largo tiempo que tienen serias dificultades cada vez que llueve. El techo del establecimiento, las estufas, y la infraestructura mínima que merecen y necesitan para estudiar, requieren urgente reparaciones. Los alumnos se ofrecen a hacer parte del trabajo, pero si luego de las vacaciones no recibieron respuestas de parte de las autoridades, prometen hacer mucho ruido hasta que los escuche.

$17 / 07 / 2014$

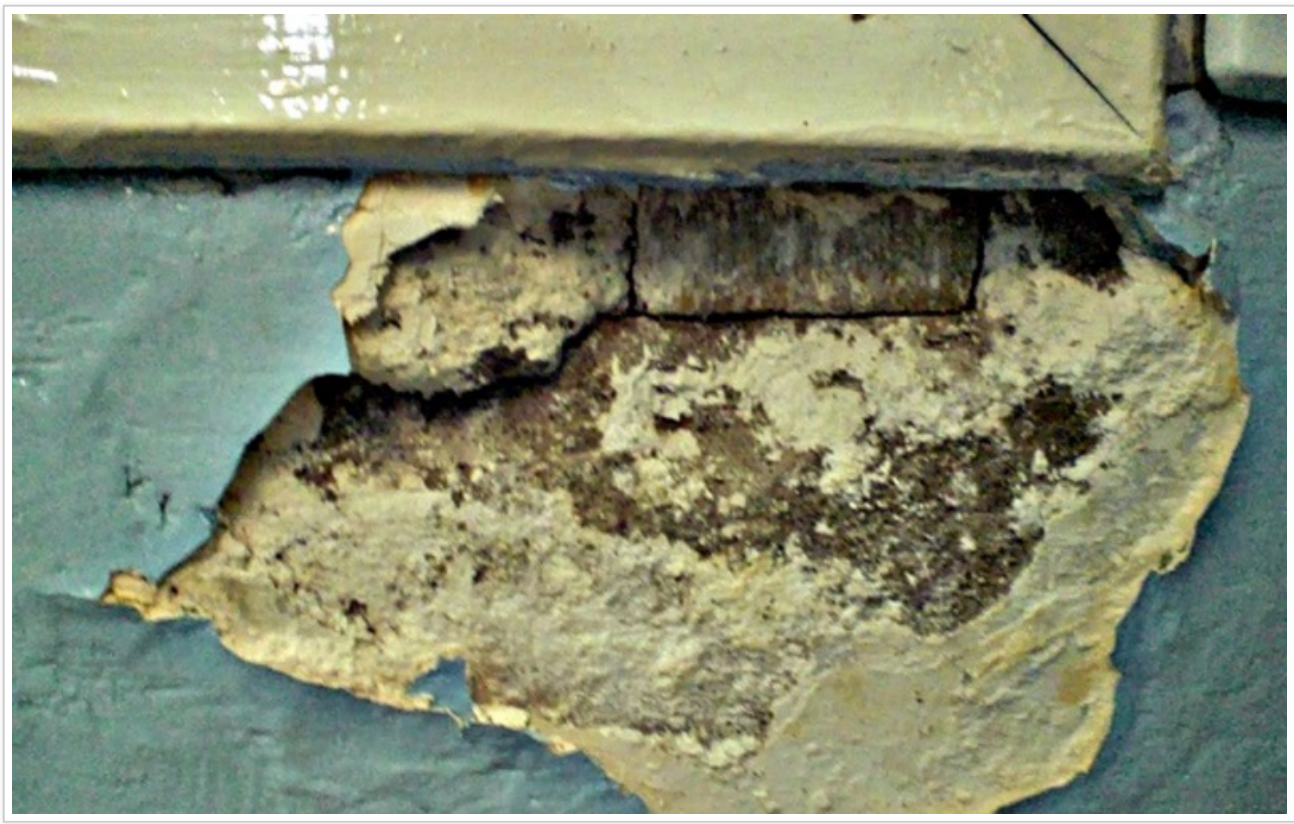

Hay que destacar, para quienes no conocen la zona, que la escuela en cuestión recibe a alumnos de ingresos medios y bajos, y por ende, no cuenta con una cooperadora que pueda suplir lo que el estado tiene que garantizar.

En invierno hace frío en toda la región, pero cuanto más cerca del Río de la Plata se está, la sensación térmica es más baja.

Los estudiantes de la Media 2 de Punta Lara hacen su reclamo por una sola razón: la ausencia del estado, el abandono y la falta de respuestas.

Organizados en un Centro de Estudiantes, canalizaron los reclamos por esa vía.
Además, aclaran: "Mandamos cartas al Consejo Escolar esperando respuestas, y por ahora no las hemos recibido. Pero si cuando terminan las vacaciones todo sigue igual, estamos decididos a avanzar a un nivel mas alto".

Cuando hablan de un nivel "más alto" hacen referencia a medidas concretas, como por ejemplo el corte total o parcial del camino costanero de Punta Lara, o alguna protesta en la sede de Educación.

"Es que cuando llueve pareciera que el techo estuviera por caerse, hay goteras de todos los tamaños, el frío es insoportable, y sin las estufas reparadas y sin la provisión constante de gas para que funcionen, prestar atención en horario de clases es imposible", explican los chicos y las chicas del Centro.

Además, prometieron seguir haciendo las gestiones necesarias ante las autoridades antes de iniciar nuevas protestas y otro tipo de medidas, para llamar así la atención de aquellos que deben dar respuestas, y que no tienen (en sus despachos tapizados y cálidos) los inconvenientes que sufren los adolescentes del único secundario de Punta Lara. 


\section{Punta Lara afectada por una nueva sudestada: varias familias evacuadas}

La crecida del Río de La Plata afectó a varias cuadras del barrio ensenadense de Punta Lara, donde las autoridades debieron evacuar a unas 50 personas que de a poco fueron regresando a sus hogares.

\section{por Blanco Negro}

18/04/2016

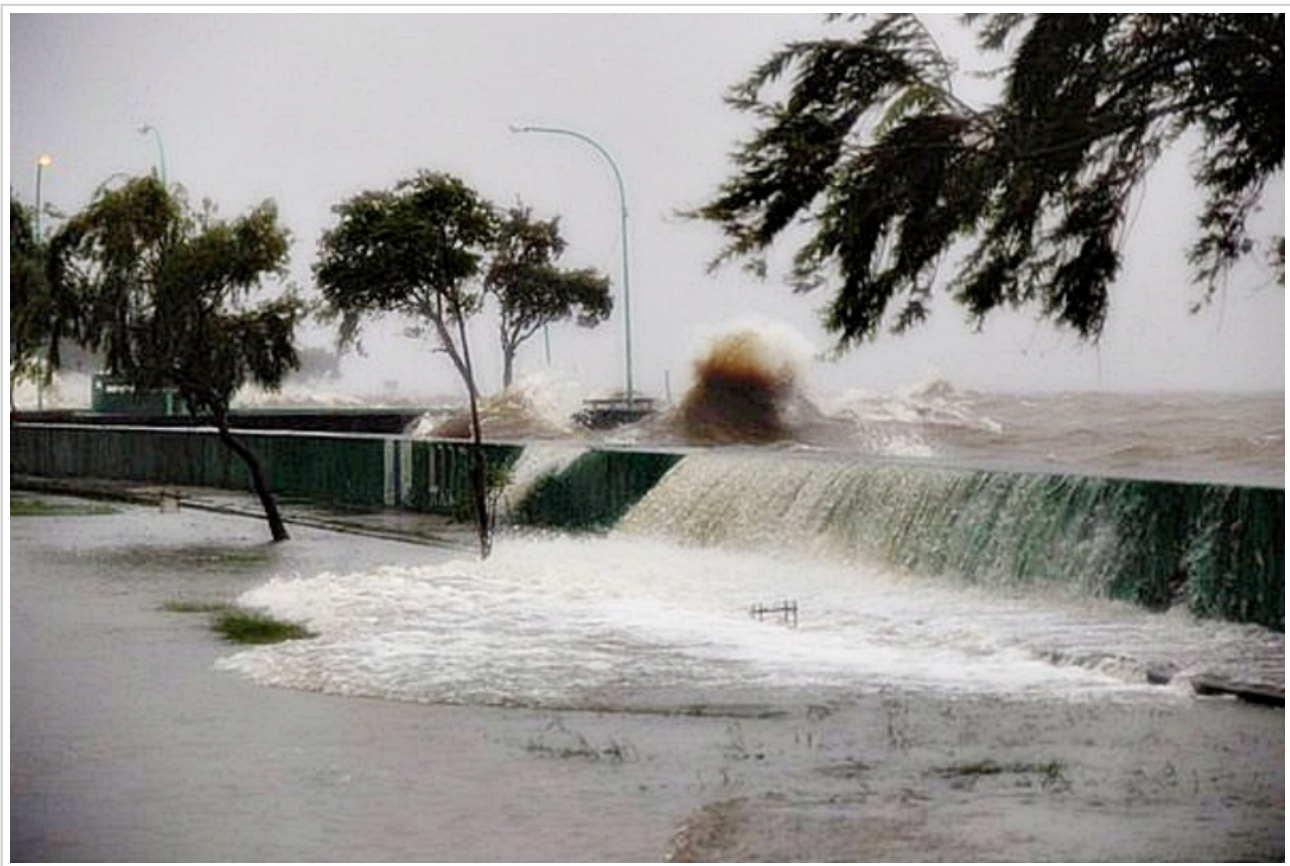

Este lunes se volvió a repetir el fenómeno meteorológico que suele complicar a la región. La Municipalidad de Ensenada montó un operativo especial para asistir a los vecinos afectados por la elevación del nivel del río. Según pudo averiguar Blanco sobre Negro debieron evacuar a 50 personas que de a poco fueron regresando a sus hogares.

El pico de la crecida del río se dio a las 17 horas cuando alcanzó los 3.15 metros. A las 19, la altura estaba en 2.80 metros y bajando.

De todos modos, varias cuadras de Punta Lara se encuentran afectadas. En la rotonda donde termina el recorrido el colectivo 275 el agua llega a las rodillas. No se registraron cortes masivos de luz, ni de teléfono. 


\section{Comenzó la "Revolución Cultural en el Río" en el mirador Néstor Kirchner de Punta Lara}

La Municipalidad de Ensenada realizó la primera jornada de "Revolución Cultural en el Río" en el Mirador Néstor Kirchner de Punta Lara. La actividad ofrece espectáculos musicales gratuitos para los vecinos y turistas que llegan a disfrutar de las costas.

\section{por Blanco Negro}

24/01/2017

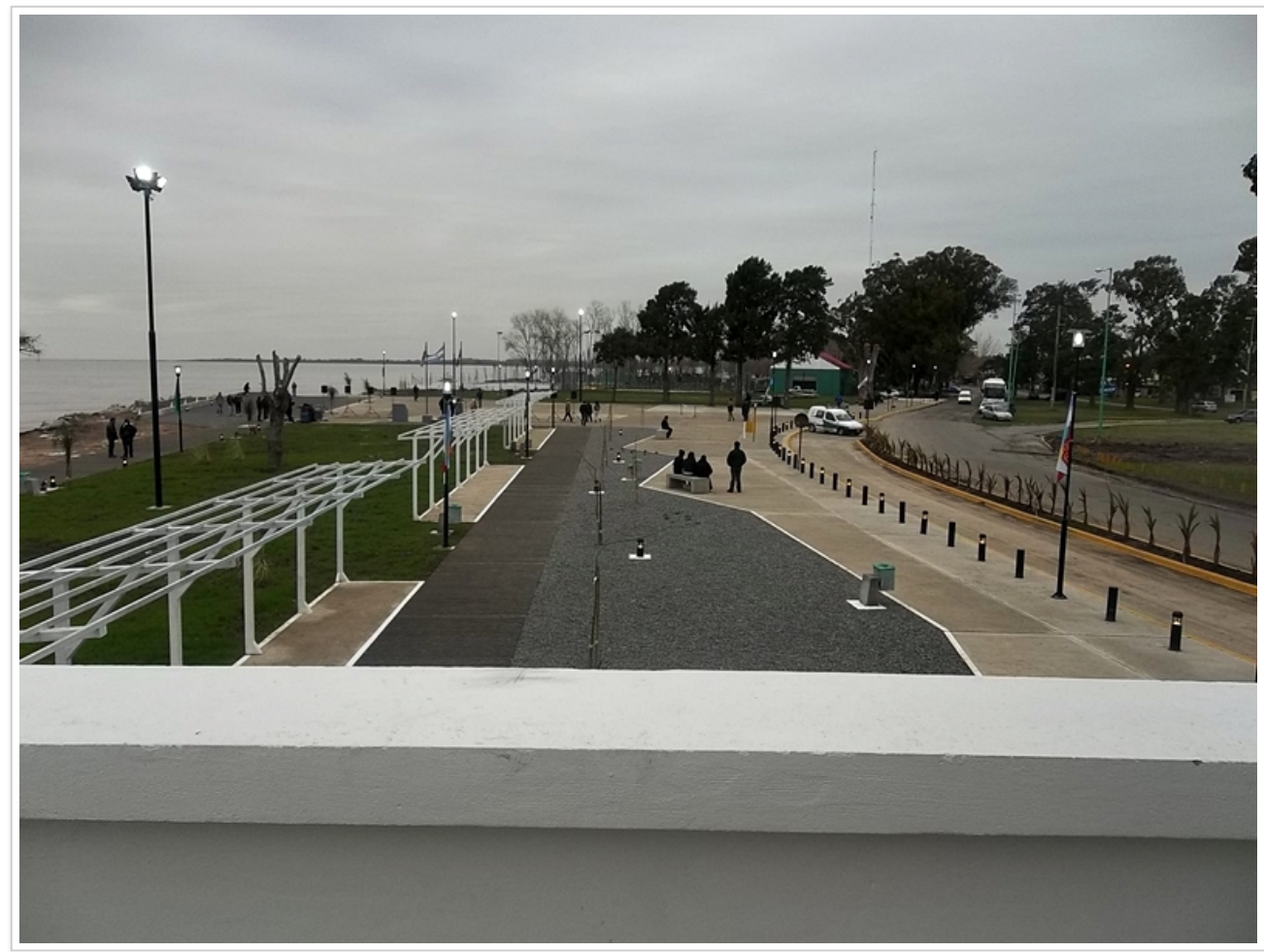

En su primera edición se presentaron: Walter Albornoz con temas de folclore, Pablo Cuomo Jr. que hizo bailar al ritmo de la cumbia, el tanguero Guillermo Díaz y el ganador del Premio Fuerte Barragán, "Chino" Becerra.

Los espectáculos se repetirán el sábado 28 con Nico y El Colo, Hugo Izaguirre, El Seba y Oscar Tevez; el 29 de enero con Gonzalo Carovillano, Taciturno, Los Borders, Hermosos Perdedores y EI Náufrago Rock; y también el 4, el 5 y el 12 de febrero, siempre a partir de las 17:30 con variadas propuestas musicales para toda la familia. 

comuna se realiza desde el 10 de enero hasta el 24 de febrero, de martes a viernes de 8 a 18, y propone actividades como aquagym, caminata, baile, tejo y diferentes juegos coordinados por

16 profesores a cargo de los distintos grupos.

"Quiero agradecer a todos los que colaboran con la realización de esta colonia, desde ATEhasta los guardavidas, y destacar el trabajo en equipo en pos del bien común, sin importar las ideologías ni los colores políticos", manifestó Garro.

En esta oportunidad, los abuelos comenzaron la jornada a las 10 de la mañana con una entrada en calor, una caminata saludable a orillas del río y clases de aquagym, para luego jugar unas partidas de Escoba del 15, Chin Chón y Sapo hasta el momento del almuerzo, junto al Jefe Comunal.

\section{La Plata}

\section{Los adultos mayores disfrutan de la colonia municipal en el Camping de ATE, en Punta Lara}

El intendente de La Plata, Julio Garro, compartió el almuerzo con más de 400 abuelos que participan diariamente de la colonia para adultos mayores que la Municipalidad desarrolla en el Camping de ATE, en Punta Lara. "Es un gran orgullo poder ser partícipe de esta experiencia que les da tanta alegría a nuestros abuelos", expresó el Jefe Comunal.

por Blanco Negro

04/02/2017

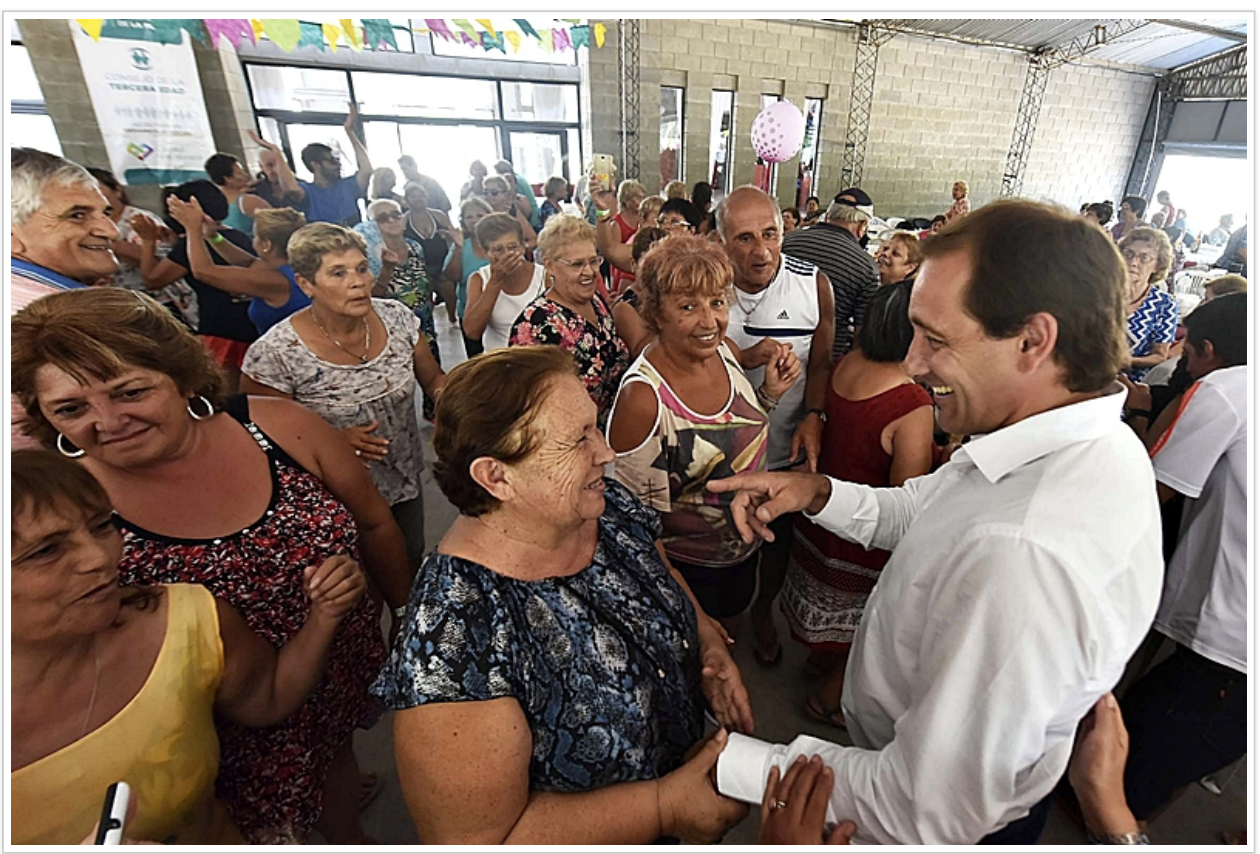

"Me alegra mucho que la pasen bien y que tengan esperanzas de vivir mejor", les dijo el intendente Garro durante el encuentro, y continuó: "Cuenten conmigo para lo que necesiten".

En la edición 2017, más de 1500 abuelos de todos los centros de jubilados de la ciudad asisten semanalmente al predio de ATE. Lo hacen a través del transporte gratuito que el municipio dispuso para trasladarlos desde y hasta el lugar y facilitarles el acceso a la Colonia. 


\section{PARA RECIBIR A MILES DE VISITANTES}

\section{Punta Lara se llena de atractivos}

Se multiplican las propuestas en la localidad balnearia

\section{2 de Febrero de 2017 | 02:08}

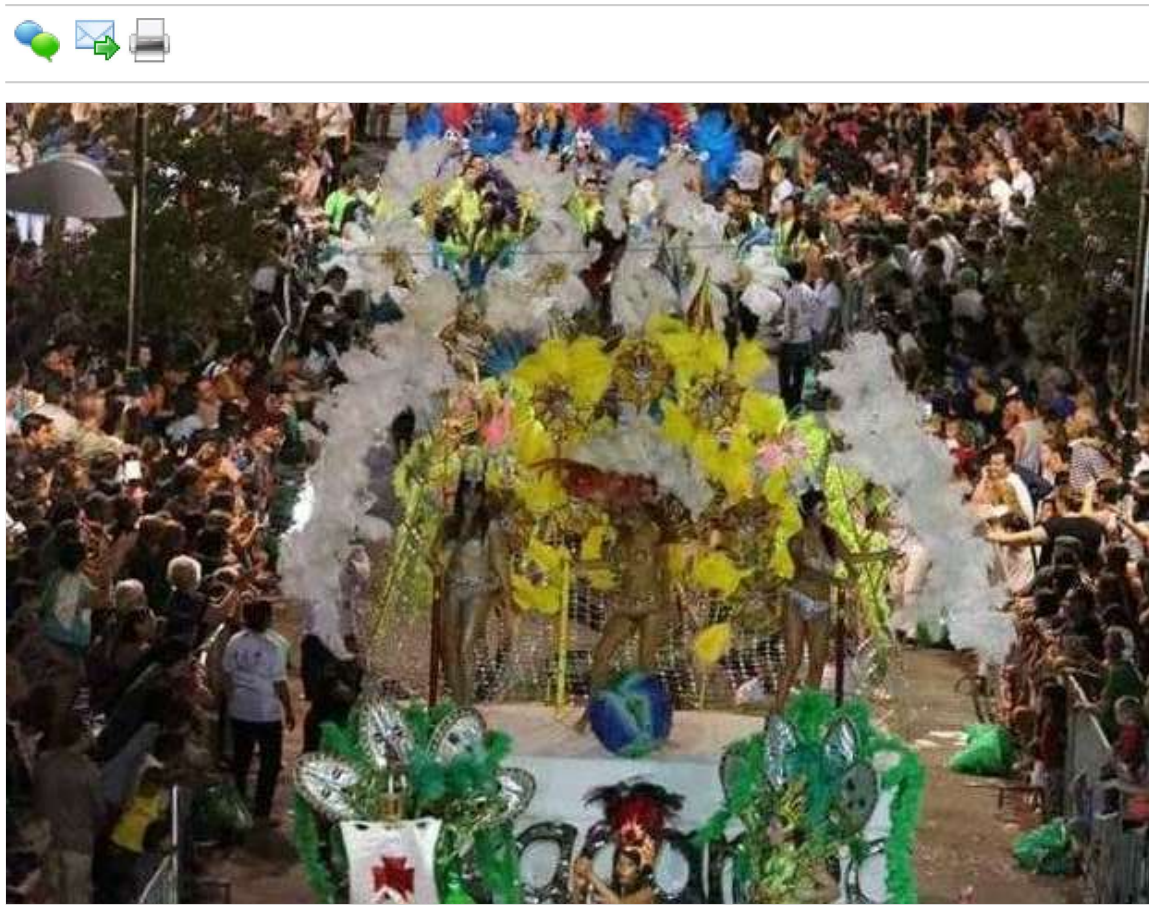

EL FESTEJO DEL CARNAVAL ATRAE CADA AÑO A MILES DE VISITANTES

Más allá de sus playas y de su reconocida actividad náutica, Punta Lara, el clásico balneario de Ensenada convertido en un importante centro turístico, cuenta con distintas alternativas para pasar un día o, incluso, un fin de semana.

La zona de la costa de la ciudad vecina, se sabe, dispone de diferentes paradores públicos en los que se puede hacer uso de los fogones, los conjuntos de mesas y sillas y de las instalaciones en general para pasar toda una jornada, entre amigos o con la familia, al aire libre.

También se ofrecen predios como para una o más jornadas de camping, donde los visitantes encontrarán diversas propuestas, como mesas de pool, parrillas, kiosco, juegos electrónicos y
Asimismo, la costa ensenadense posee una nutrida variedad de locales comerciales que se extiende a lo largo de la avenida Almirante Brown, ofreciendo productos de las gamas más variadas, ampliando el abanico de oportunidades para los visitantes.

La gastronomía es otro imán para quienes disfrutan del fin de semana en Punta Lara; en distintos locales existe el atractivo de optar por una buena degustación de exquisitos platos, desde picadas, mariscos o parrilladas.

Entre las opciones de Punta Lara para entretener a grandes y chicos se cuenta con los museos Fuerte Barragán y el de Veteranos de Malvinas, una Feria de Artesanos, la Feria de las Colectividades y un Parque de Diversiones donde se encuentran juegos para disfrutar en familia.

Los días 26 y 27 de febrero los visitantes podrán disfrutar de los espectaculares Carnavales, con la participación de O’Bahia y Macumba, comparsa en la que participan más de 60 bailarinas y bailarines y cuenta con dos batucadas. También se podrán apreciar comparsas locales. Los espectáculos serán con entrada libre y gratuita y se espera una multitud.

Otra de las claves de la ribera ensenadense es que la entrada es libre y gratuita. Posee un acceso rápido y sencillo desde cualquier zona que se emprenda el viaje: tanto desde La Plata y Berisso como desde el Norte y Oeste del Gran Buenos Aires.

Punta Lara ha recibido en distintas temporadas de verano hasta dos millones de turistas que llegan sobretodo del Gran La Plata y el Gran Buenos Aires.

Ver comentarios 


\section{En Ensenada calculan que unas 80 mil personas disfrutaron de otro "superdomingo" en Punta Lara}

Punta Lara vivió otro Super Domingo con la visita de más de 80 mil vecinos de la región y la provincia, que disfrutaron de la costa libre y gratuita, espectáculos en vivo, un festival gastronómico y el Paseo de los Artesanos. La jornada se realizó en el marco del Operativo Verano que lleva adelante el Municipio para garantizar la seguridad en la zona.

\section{por Blanco Negro}

07/01/2018

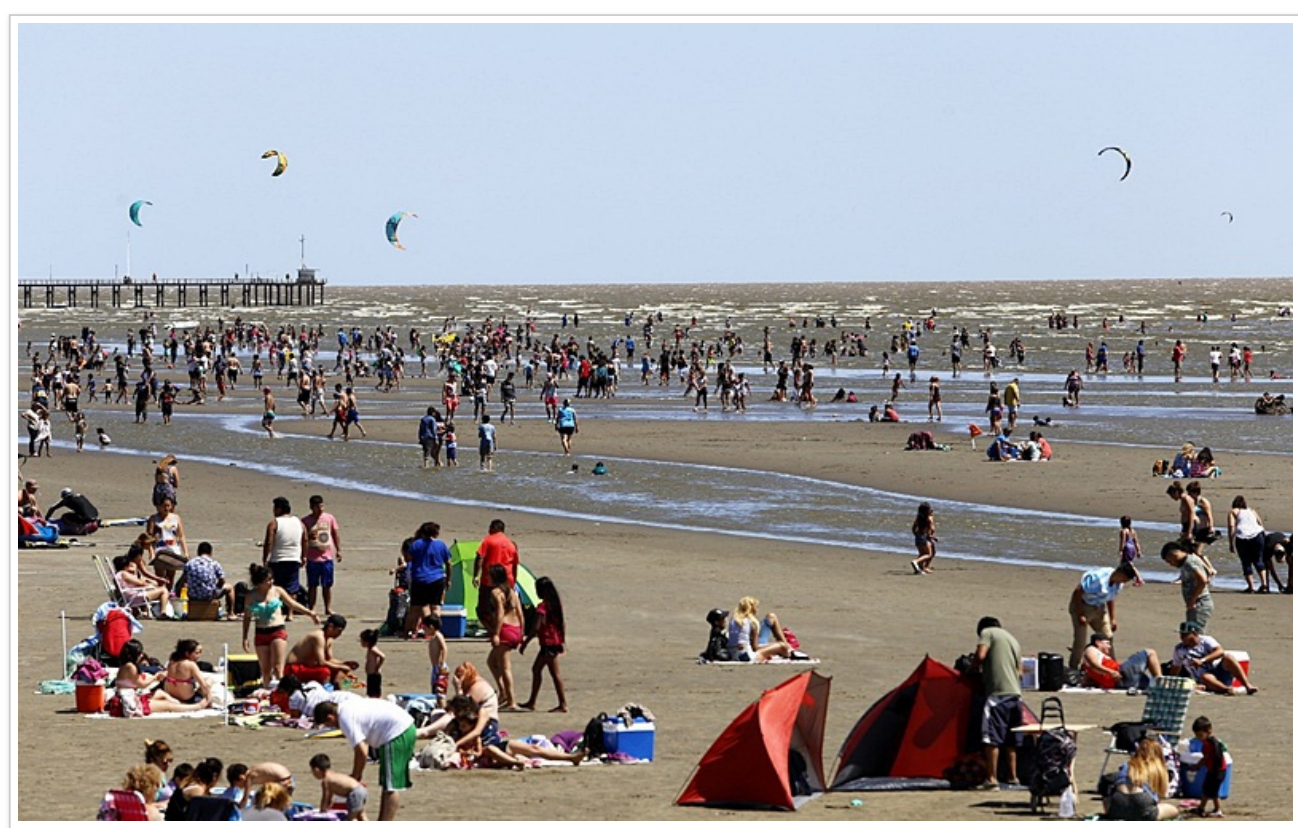

"La gran cantidad de visitantes es posible gracias al desarrollo del Parque Costero que impulsó y construye la Gestión Mario Secco, que da lugar a espacios de acceso público y deja atrás a los campings privados. Asimismo, se ofrecen bancos, parrillas, baños públicos, luminaria y parquización", señalaron desde la Municipalidad.

A esto debe sumarese el Operativo Verano que incluye el trabajo de la Dirección de Turismo con el control y mantenimiento de la costa, y el servicio del cuerpo de guardavidas municipal; la Secretaría de Servicios Públicos y las Cooperativas con la limpieza y abastecimiento de agua; la Secretaría de Salud con el Servicio de Emergencias Médicas; la Dirección de Comercio con la supervisión de los puestos y comercios; la Dirección de Tránsito con el control vehicular: la Secretaría de Seguridad con la coordinación con la Policía Local, el Comando de Patrullas y la Comisaría. 


\section{LA CIUDAD}

EN ENSENADA ASEGURAN QUE LOS OPERATIVOS DE LIMPIEZA YA ESTÁN EN MARCHA

Plagadas de basura y de sábalos muertos, se quejan por la mugre en playas de Punta Lara

Cada fin de semana recibe miles de visitantes pero la costa queda a la miseria por la cantidad de residuos que tiran y por los pescados

10 de Enero de 2018 | 01:56 | Publicado en Edición Impresa

\section{曰马}

[AA] $[\bar{A}$

La costa de Punta Lara presenta un aspecto desagradable por la acumulación de la basura y de sábalos muertos que inundan la playa.

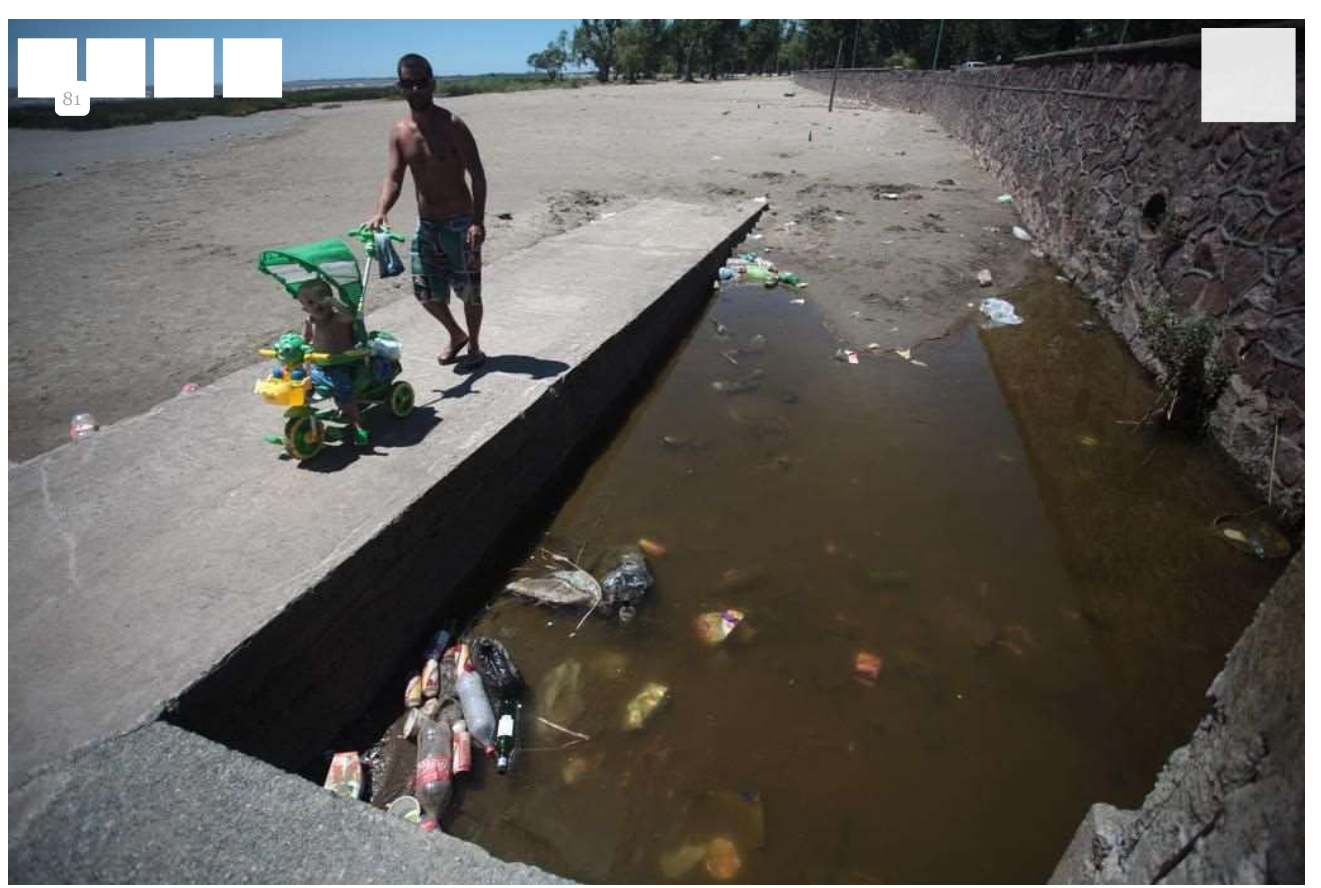

LA BASURA QUE SE ACUMULA EN LAS PLAYAS ENSENADENSES, PESEA LOS OPERATIVOS DE LIMPIEZA, GENERA QUEJAS ENTRE LOS VISITANTES / GONZALO MAINOLDI

Según explican en la Municipalidad de Ensenada, los lunes se hace la limpieza del sector parquizado y el martes le toca el turno a la playa.

ntps-//mmueldiacom/notal2018-1-10-1-56-19-plagadas-de basura-yde-sabalos-muertos-se- quejan-por-la-mugre en-playas-de punta-lara-la-ciudad
LE PUEDE INTERESAR

Proyectan un predio con estacionamiento y patio gastronómico para los manteros

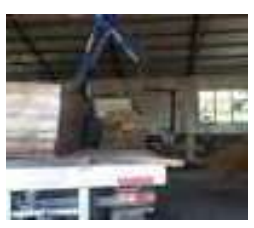

Tras los reclamos, vuelve el programa de equinoterapia a "la Repu" de Gonnet

Sin embargo, en la arena ayer todavía se podía observar un panorama desalentador para la atracción turística. 


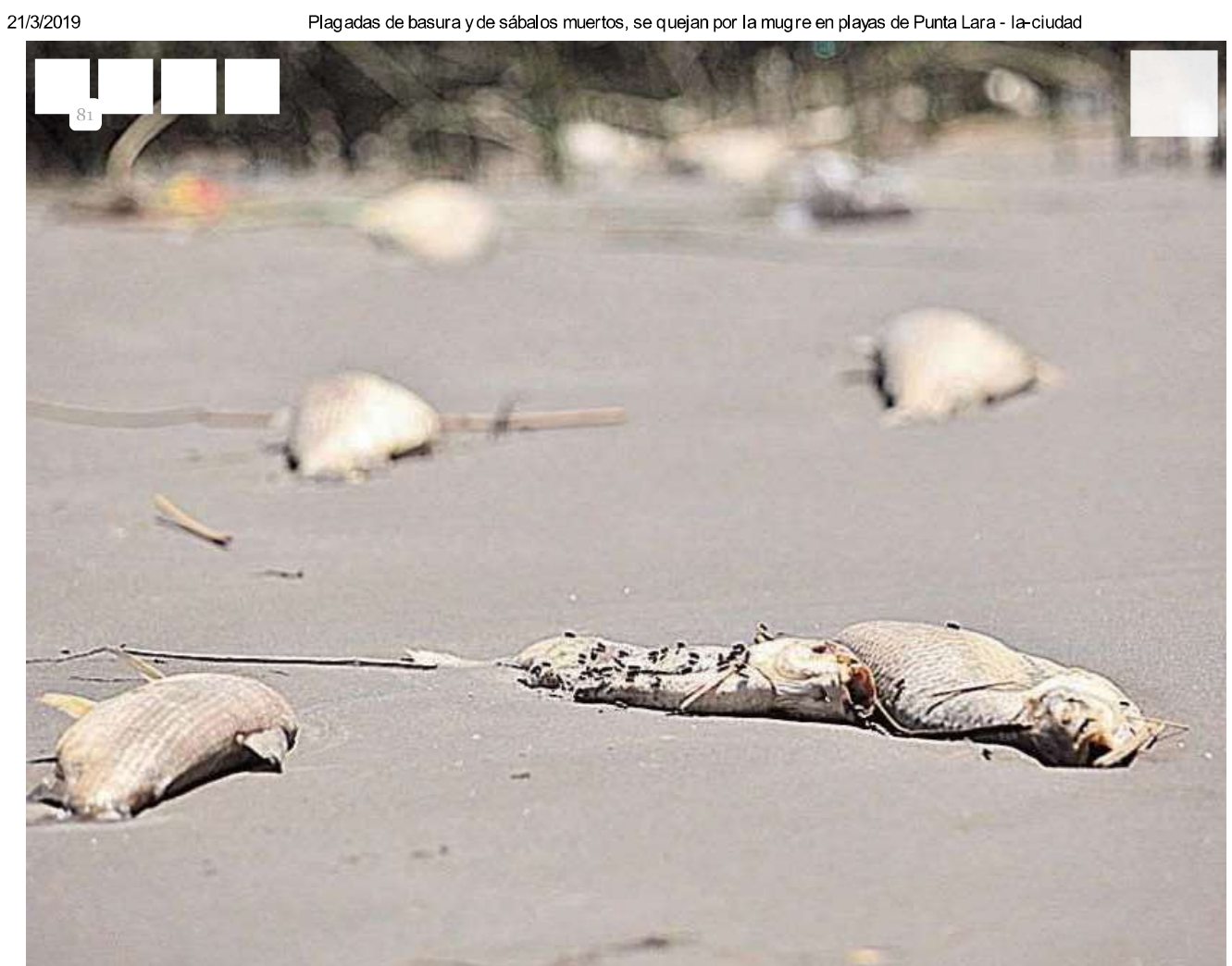

SÁBALOS MUERTOS DOMINAN SECTORES COSTEROS / GONZALO MAINOLDI

Residuos de toda clase se veían acumulados y el olor nauseabundo era muy fuerte a lo largo de la costa ensenadense.

Quienes van a trotar por la zona, fundamentalmente vecinos de la localidad ensenadense, optaron por correr sobre la cinta asfáltica porque resultaba "imposible" esquivar la cantidad de desechos acumulados a la vera del río.

La zona de la primera rotonda hacia Boca Cerrada se presentaba ayer como una de las más afectadas por la acumulación de basura y sábalos muertos.

"Después del fin de semana, la costa queda impresentable. La gente no tiene mucha disciplina, tira las cosas en cualquier lugar y después se acumula en diferentes sectores", comentó Isabel Vargas, una vecina de Punta Lara que habló con este diario.

Los vecinos dicen que debiera haber un poco más de control los domingos, cuando va la mayor cantidad de turistas a la costa de Punta Lara.
"Sabemos que es imposible controlar a todo el mundo, pero si hubiera más presencia de inspectores quizás la gente piensa dos veces antes de tirar algo a la playa", dijo otra vecina de Punta Lara.

Según explicaron en la Municipalidad de Ensenada, la "limpieza en la playa depende de la marea. Si nos permite entrar, lo hacemos cuánto antes, de lo contrario tenemos que esperar".

En uno de los muelles se vio ayer una especie de "pileta" con agua turbia, cargada de residuos y algunos sábalos en estado de descomposición. "Un asco", describió Silvio Martínez, un joven que fue a trotar y se encontró con ese panorama.

Según cifras oficiales, el día de mayor concurrencia a las playas de Punta Lara es el domingo. $\mathrm{Y}$ el mejor de todos desde que arrancó la temporada fue el pasado 7 de enero, cuando asistieron cerca de 80.000 personas, en contraste con el sábado, en el que fueron cerca de 20.000 asistentes".

Sobre la presencia de sábalos muertos, en el municipio de Ensenada indicaron que "se trata de un cruce de corrientes frías y cálidas, que terminan por afectar a los peces y a los pocos días se ven en la costa. Se trata de tres o cuatro días por temporada. Ya estamos acostumbrados porque nos ocurre todos los años. En cuanto se puedan meter las máquinas, se realizará el operativo de limpieza para dejarla en condiciones para el próximo fin de semana”.

\section{AÑO TRAS AÑO MÁS BASURA EN LA COSTA}

Desde hace varios años, alumnos de la Región participan de la limpieza de costas en Punta Lara y se encuentran con resultados desalentadores.

Según Liliana Toranzo, titular de la Ong Recrear, "en su mayoría se trata de plásticos, que tardan entre 100 y 400 años en degradarse".

En el primer puesto de un ranking de basura encontrada en la costa ensenadense lo ocuparon las tapas de botellas (plástico), ya que los chicos y chicas recolectaron 665, seguidas por las botellas de plástico para bebidas (586), bolsas de plástico para mercaderías diversas (535), pedazos de plástico (458), botellas de vidrio para bebidas (226), tapas de plástico (198), colillas de cigarrillos (183), recipientes de telgopor de comida para llevar (94), vasos y platos de papel (83) y otras bolsas de plástico (57). En total se juntaron 530 kilos de residuos sólidos en un operativo que se realizó en noviembre último.

\section{Corrientes}




\section{Indignación en Punta Lara por formación de basural}

Quejas por la acumulación de desechos en la esquina de 100 y 5

22 de Julio de 2018 | 09:54

$$
\text { Q } \triangle 9
$$

"Estas fotos son la pequeña muestra del barusarl que tenemos acá en la esquina", comentó una mujer al enviar fotos al WhatsApp de EL DIA para graficar los cúmulos de basura que se forman en el cruce de las calles 100 y 5, en Punta Lara.

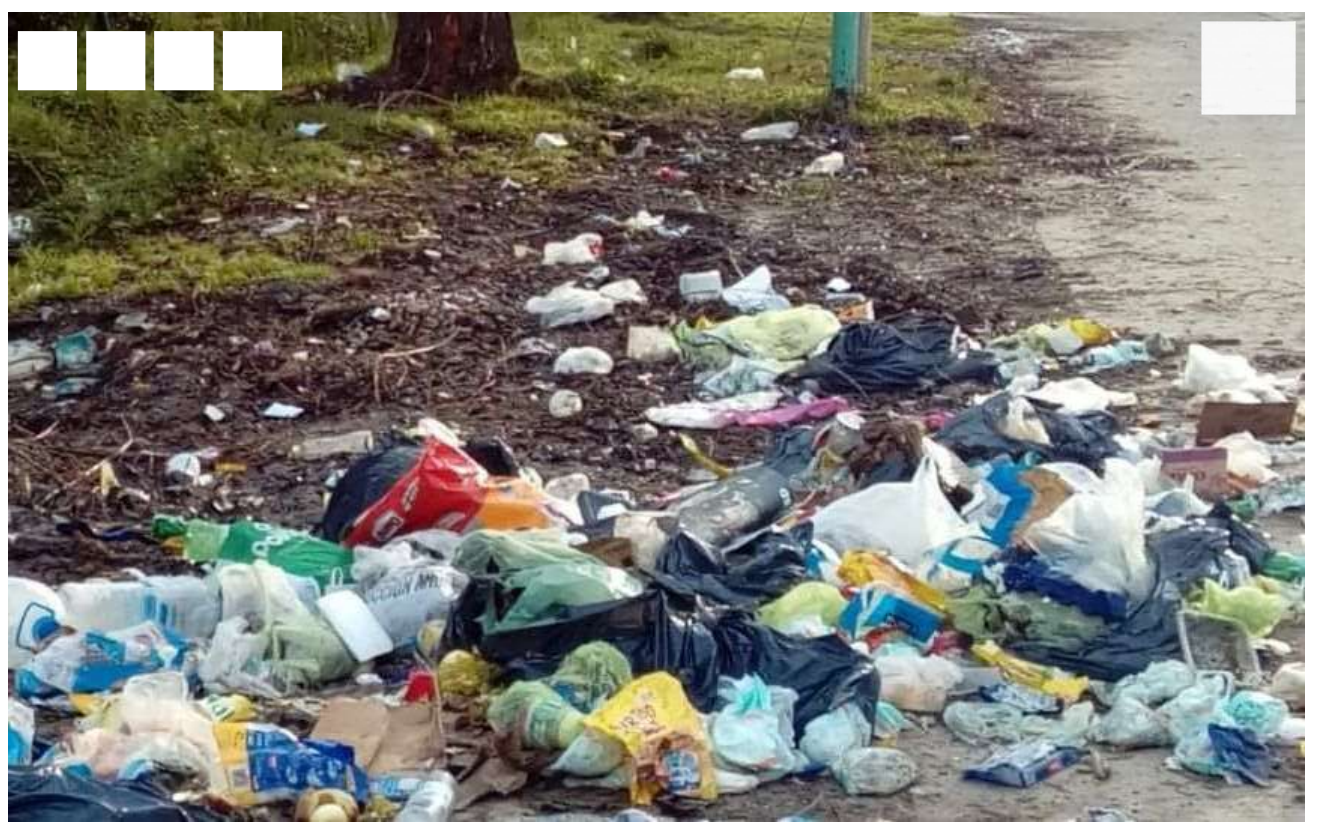

"Varias veces se ha solicitado un canastro grande para que los vecinos depositen sus bolsas y no tengan que pasar por esto. Como resultado de esta precariedad los perros aparecen por la noche y rompen todo, hacen un desastre, tal como se ve en las fotos", sostuvo la denunciante.

\section{LE PUEDE INTERESAR}

Controlá el Cartonazo $\$ 200.000$ pueden ser tuyos

syegris

200.00

"Se arregla la parte de la playa, pero los que vivimos barrio adentro no tenemos soluciones a estos problemas", manifestó la vecina ensenadense.

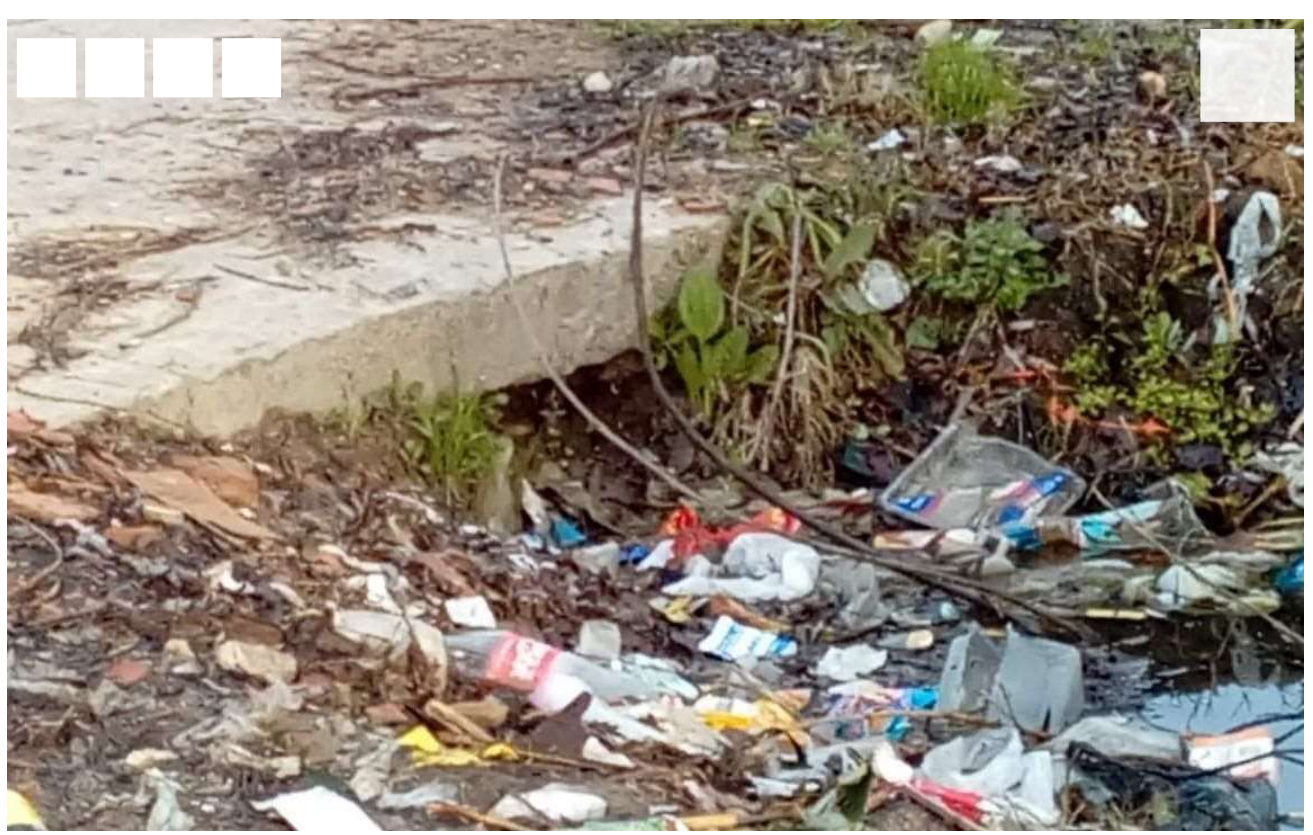

Ver comentarios 


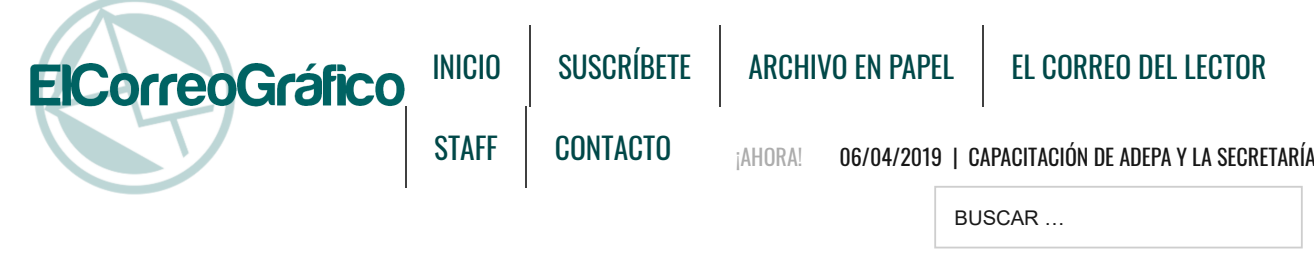

VOLVER AL INICIO ENSENADA

\section{Más Baños Y}

Acondicionamientos De Las Playas De Punta Lara

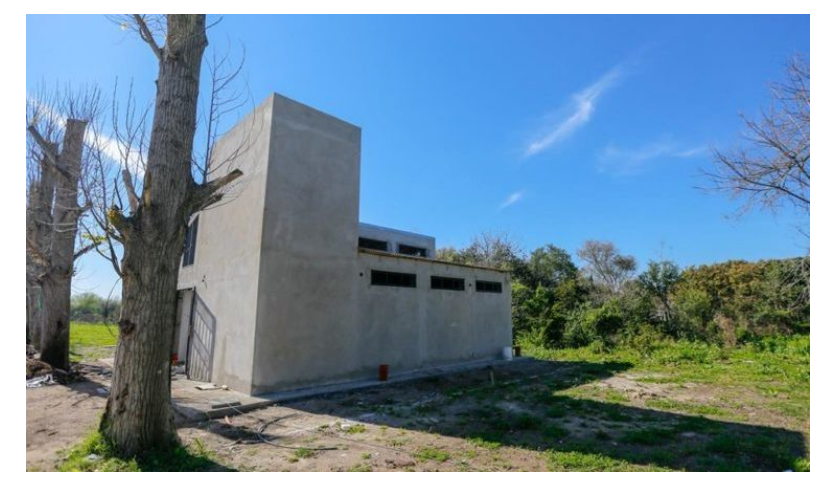

NOTICIA PUBLICADA / EDITADA POR: DARÍO FRANCO MEDINA 02/10/2018

Tiempo de Lectura: 1 minuto

Con el objetivo de continuar mejorando la calidad de los servicios en el Parque Costero de Punta Lara, se

construyeron nuevos baños públicos en distintas playas.

En forma paralela, continúa la colocación de 2000

bancos, 1000 mesas, 500 fogones y luminaria. El nuevo espacio generado representa 200 plazas. Entre todos y todas, vecinos y turistas, debemos cuidarlo y preservarlo, arrojando los desperdicios en los respectivos cestos. 


\begin{tabular}{|c|c|c|c|c|}
\hline CorreoGráfico & INICIO & SUSCRÍBETE & ARCHIVO EN PAPEL & EL CORREO DEL LECTOR \\
\hline & STAFF & CONTACTO & ¡AHORA! 06/04/2019 | & $\begin{array}{l}\text { PACITACIÓN DE ADEPA Y LA SECRETARÍA } \\
\text { CAR ... }\end{array}$ \\
\hline
\end{tabular}

VOLVER AL INICIO ENSENADA

\section{Punta Lara, La Costa Más Linda Del Río De La Plata}

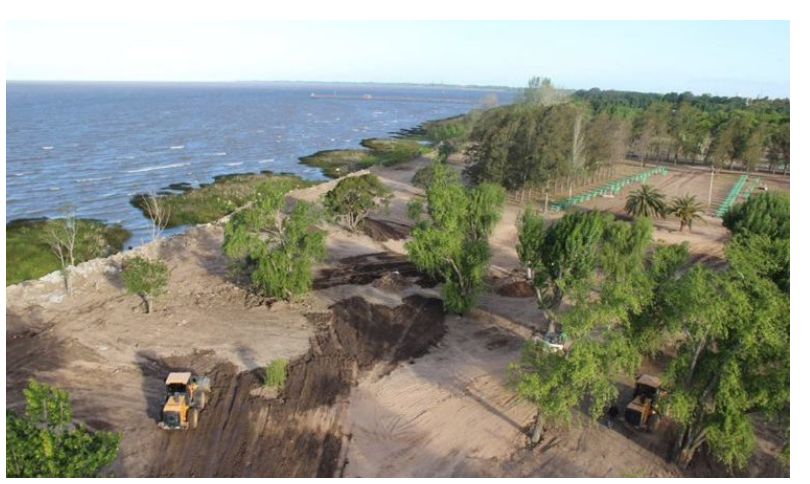

NOTICIA PUBLICADA / EDITADA POR: DARÍO FRANCO MEDINA 25/10/2018

Tiempo de Lectura: 1 minuto

La Municipalidad de Ensenada sigue trabajando para generar más espacios públicos a orillas del Río de la

Plata. En otra de las obras transformadoras de la

\section{Gestión del Intendente Mario Secco, el Parque}

Costero de Punta Lara va tomando color. En estas imágenes aéreas, se dimensiona cómo se continúa valorizando la costa ribereña.

Con un intenso trabajo del personal municipal, poniendo en la cancha una importante flota de máquinas y camiones de la comuna, avanzan los trabajos de relleno y nivelación en diversos paradores públicos del Parque Costero. El espacio recuperado equivale a 200 plazas y en algunos lugares de los 14 kilómetros de costa
En los sitios donde la obra está más avanzada, ya se instalaron columnas de iluminación led, bancos, mesas, fogones, baños, cestos de residuos y se forestará con nuevas especies arbóreas. Equipando cada parador para brindar el mejor servicio, Punta Lara está cada día más linda.

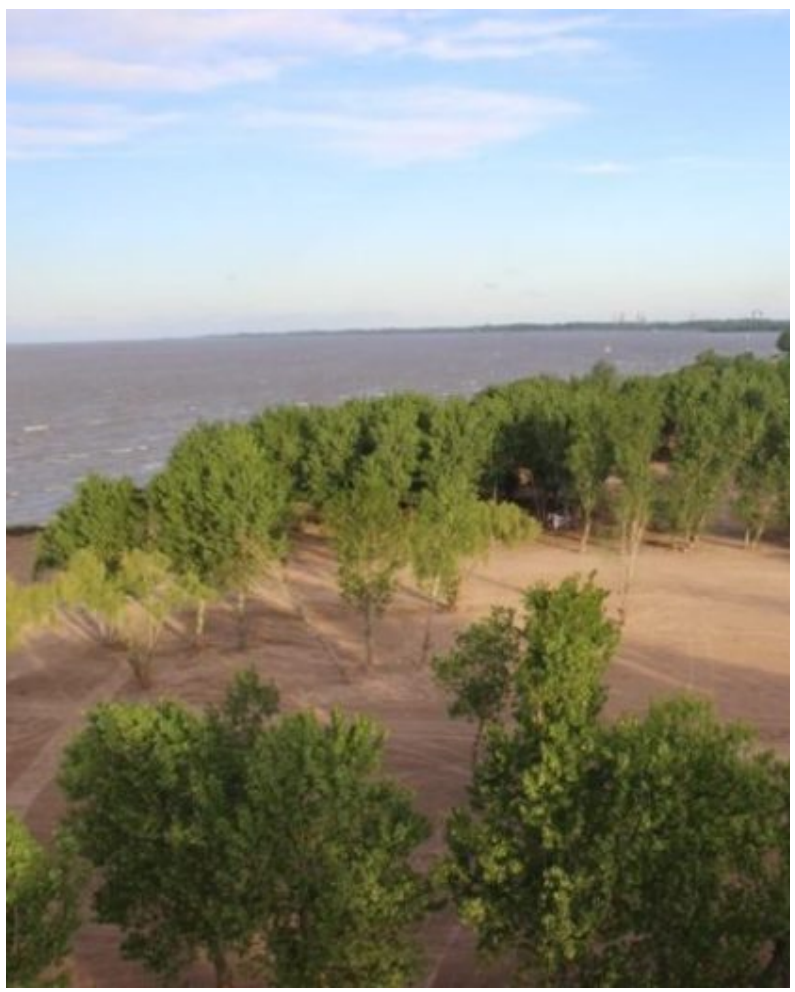


El Parque Costero de Punta Lara continúa creciendo y brindando nuevos espacios ideales para que todos y

todas puedan disfrutar de las playas más lindas del Río de la Plata. Cada fin de semana, vecinos de la ciudad y la región se acercan a los paradores municipales 0 sobre diagonal 74 para tomar mate, disfrutar el sol y recrearse en familia.

El Intendente Mario Secco tomó la decisión política de liberar la costa para que todos puedan contar con espacios libres y gratuitos donde vacacionar y disfrutar de espacios públicos. Necesitamos la colaboración de los vecinos y turistas para cuidar los paradores que son de todos.

\section{El Mirador De Punta Lara Recibió A Comparsas De La Región}

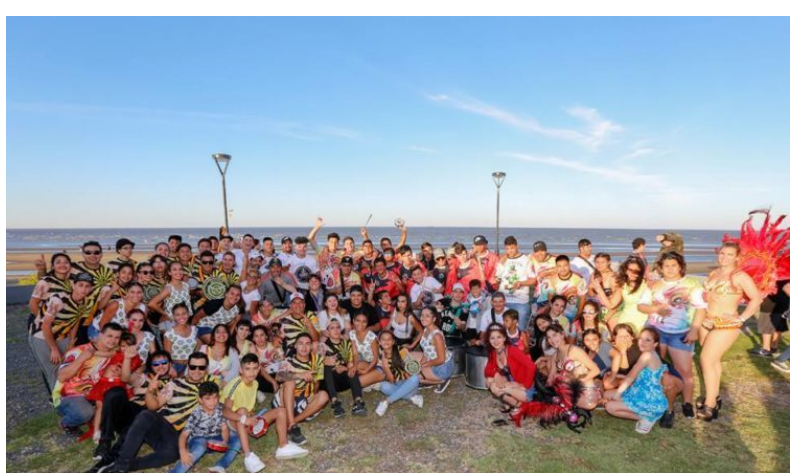

NOTICIA PUBLICADA / EDITADA POR: DARÍO FRANCO MEDINA 07/11/2018

Tiempo de Lectura: 1 minuto

El pasado fin de semana, el Mirador Néstor Kirchner recibió un gran encuentro de comparsas, donde cada una mostró el trabajo que vienen desarrollando durante todo el año.

Vecinos y turistas disfrutaron de la música y el baile con la que cerró un domingo de temporada adelantado. La Batería Halcones, la Comparsa Arema y Ohana mostraron el color y alegría del carnaval junto a comparsas de la provincia.

\section{BUSCAR}




\section{Quejas por basura en Punta Lara mientras avanza la obra del parque ribereño}

Vecinos y organizaciones ambientalistas mostraron su preocupación

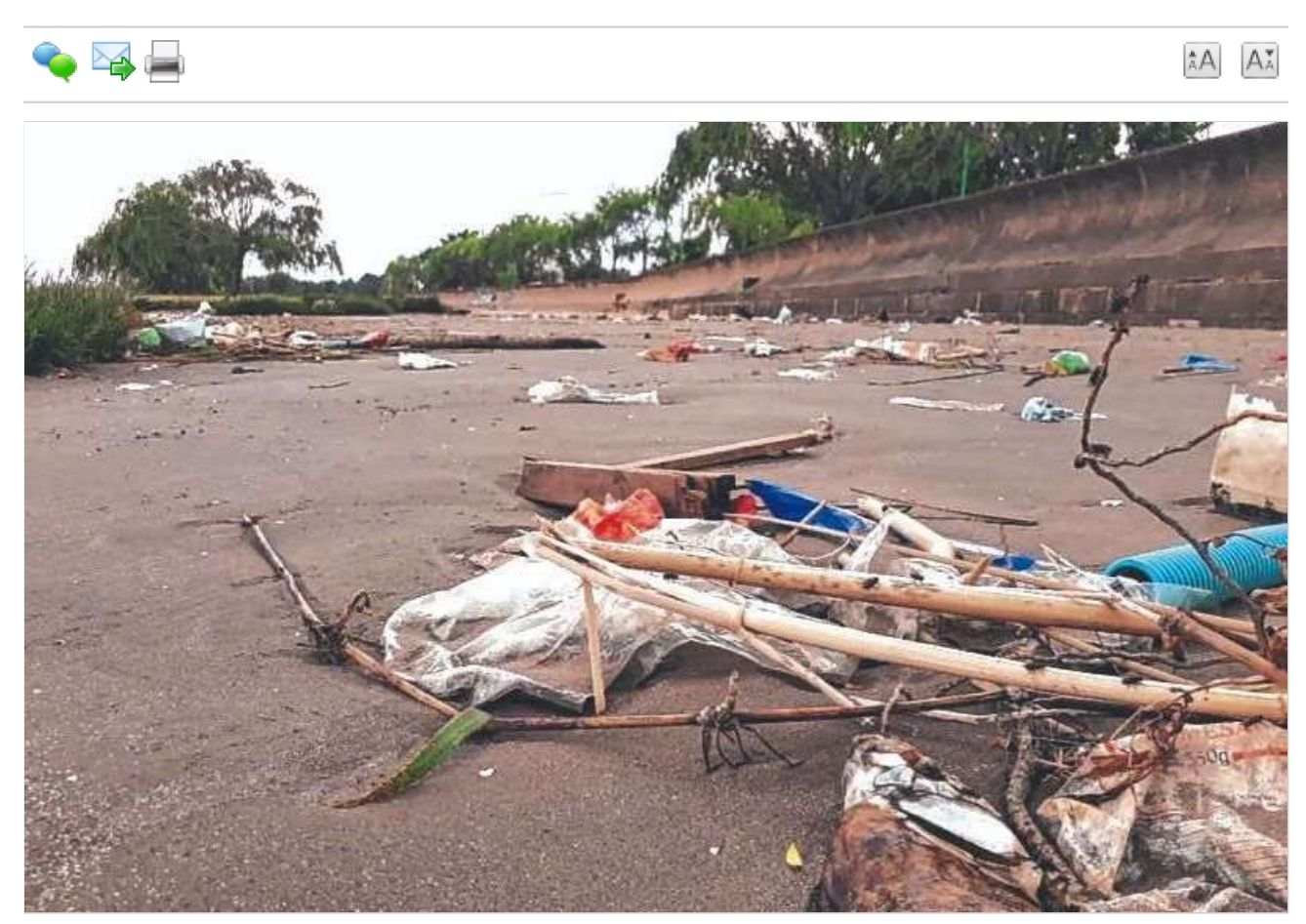

Berisso: habían grafiteado un edificio público y repararon el daño

Con buen ritmo se desarrollan las obras del futuro parque ribereño ensenadense en la localidad de Punta Lara, impulsado por el Municipio, lo que trajo como consecuencia la presencia de gran cantidad de basura. El resultado, cabe recordar, será un paseo peatonal elevado, con playas de estacionamiento, que tendrá más de tres kilómetros de longitud desde el paraje que alberga al palacio Piria hasta la zona de la rotonda Stella Maris.

Desde el inicio de los movimientos de suelo para rellenarlo, los desperdicios aparecieron y vecinos y organizaciones ambientalistas manifestaron fuertemente sus quejas.

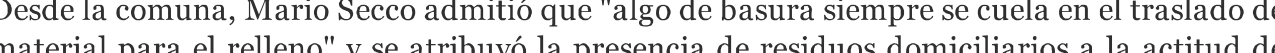
algunos vecinos.

Por otro lado, las autoridades ensenadenses sostienen que estas situaciones "se van corrigiendo en la medida de lo posible" y que el objetivo final es crear "una superficie recreativa de acceso libre".

Sin embargo, entidades como la ONG Nuevo Ambiente denunciaron el empleo de losas de pavimento y el ex fiscal platense Rubén Sarlo radicó en la Justicia Federal una denuncia por contaminación y degradación de los recursos de agua. 


\section{ENSENADA}

Punta Lara 2018-19: este finde se lanza la temporada de verano

El acto de apertura se realizará este domingo 2 de diciembre a las 18 en el Mirador Néstor Kirchner. El municipio de Ensenada ofrecerá a vecinos y turistas más paradores de acceso libres y gratuitos para que disfruten del sol, la playa y el río.

30 de noviembre de 2018

Este domingo 2 de diciembre a las 18 lanzarán oficialmente la temporada de verano en la costa de Punta Lara. Será en el Mirador Néstor Kirchner con un acto organizado por la Municipalidad de Ensenada.

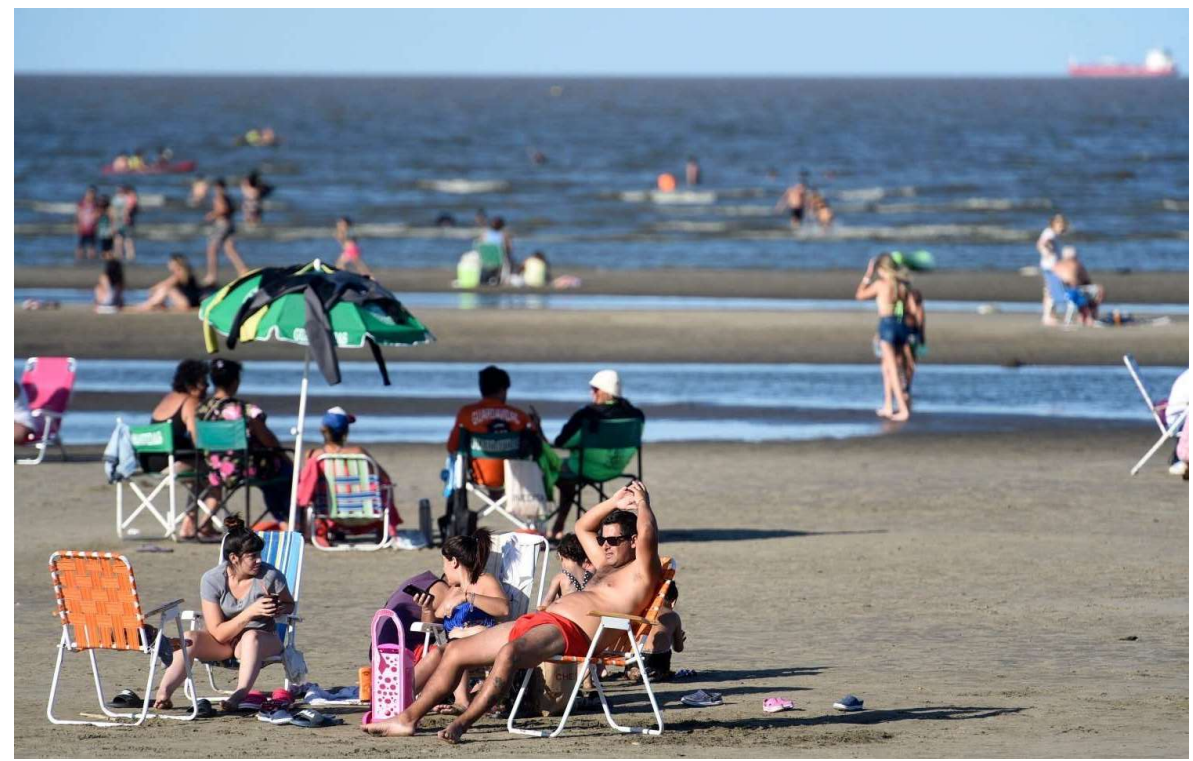

El evento se desarrollará exactamente en diagonal 74 y Camino

Almirante Brown. Allí se presentará el Operativo de Seguridad en Playa que incluye el trabajo articulado de numerosas áreas municipales y fuerzas de seguridad del distrito.

Además, durante la jornada los presentes podrán disfrutar de un gran encuentro de bandas militares, como el Regimiento de Infantería Mecanizado 7 "Coronel Conde", el Regimiento de Caballería de Tanques 8 "Cazadores General Necochea", Prefectura Naval Argentina, Escuela
Naval, la Banda Militar "Ituzaingó" del Regimiento de Artillería 1 "Brigadier General Tomás de Iriarte", y la Banda Infanto Juvenil de Música del Municipio de Ensenada.

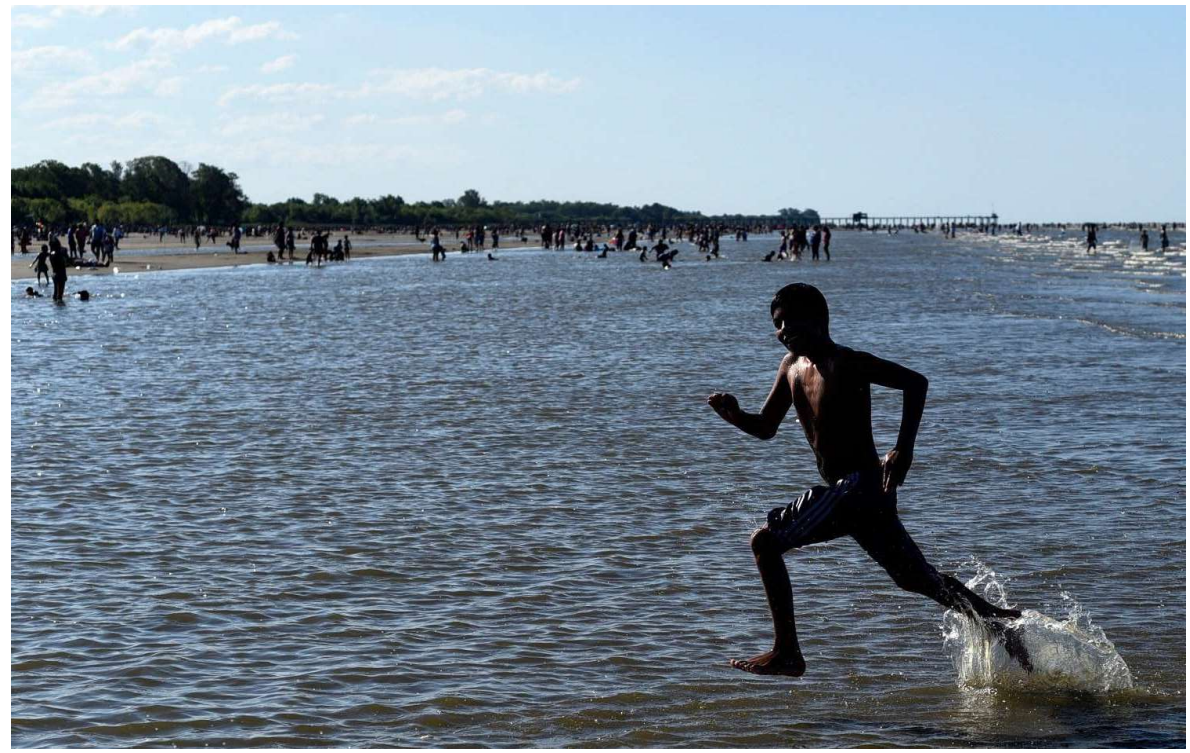

Desde Ensenada informan que el municipio lleva adelante, durante todo el año, tareas de mantenimiento en los $14 \mathbf{~ k m}$. de costa "con el objetivo de brindarles a los vecinos y turistas más paradores de acceso libres y gratuitos para que disfruten del sol, la playa y el río".

Es que en 2003, el intendente Mario Secco tomó la decisión de liberar los campings privados para transformar la costa en un gran espacio público de acceso libre y gratuito. Desde este domingo se puede visitar una vez más, como todos los veranos. 


\section{FUNCIONARÁ EN PUNTA LARA}

Aquagym, baile y tejo: abrió la inscripción para la colonia de la tercera edad

Se desarrollará desde el martes 8 de enero hasta el viernes 22 de febrero de 9 a 17 horas en las instalaciones del camping de ATE de Punta Lara. ¿Cómo inscribirse y cuáles son las actividades previstas?

07 de diciembre de 2018

La Municipalidad de La Plata abrió la inscripción para la colonia de la tercera edad que se realizará en el camping de ATE de Punta Lara entre el 8 de enero y el 22 de febrero.

La propuesta impulsada por la comuna, se llevará delante de martes a viernes de 9 a 17 horas en el camping de ATE, ubicado en la rotonda de Punta Lara, con actividades como aquagym, caminata, baile, tejo y distintos juegos. En tanto, al igual que el año pasado, el Municipio pondrá a disposición traslados gratuitos desde diferentes centros de jubilados de la ciudad.
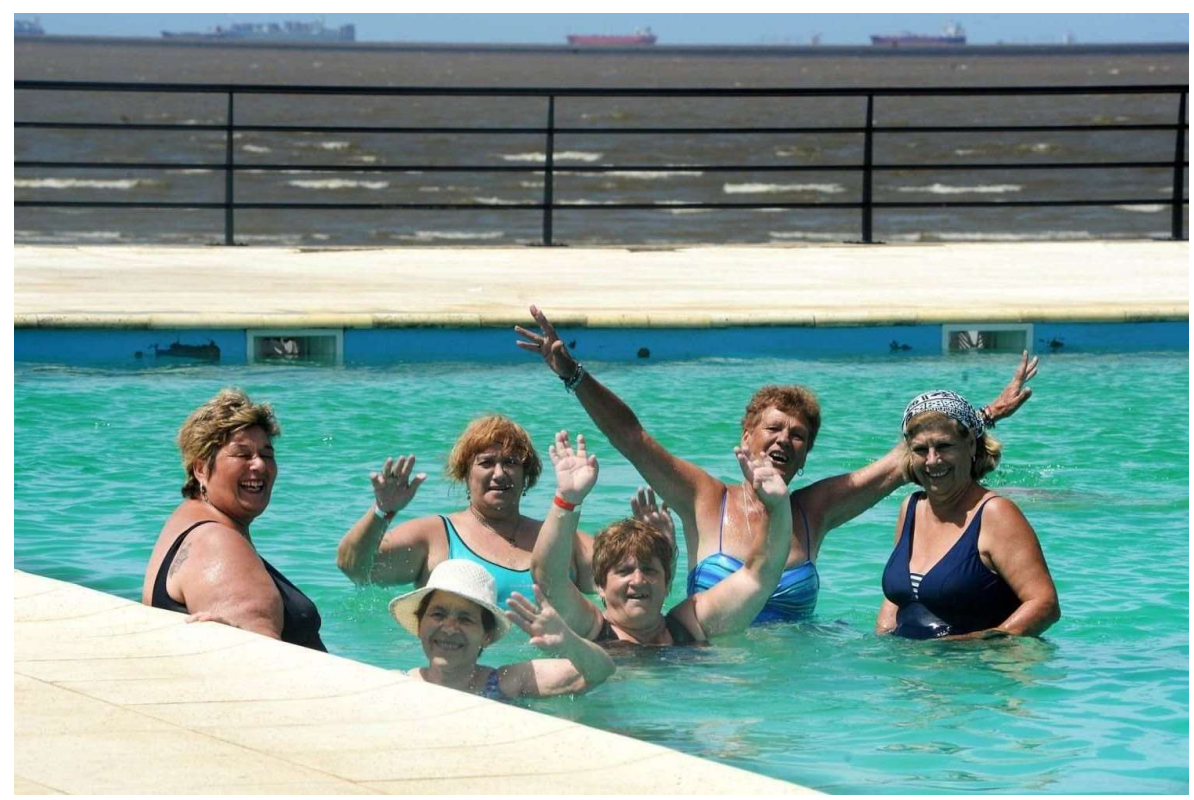

Foto: Archivo de la colonia del verano 2018
Los adultos mayores pueden elegir un día a la semana para asistir a la colonia y los delegados de cada centro organizarán el cronograma con todos los datos pertinentes para los traslados que se brindan en forma gratuita, con un servicio de diez micros de alta gama que llegan a diferentes puntos establecidos.

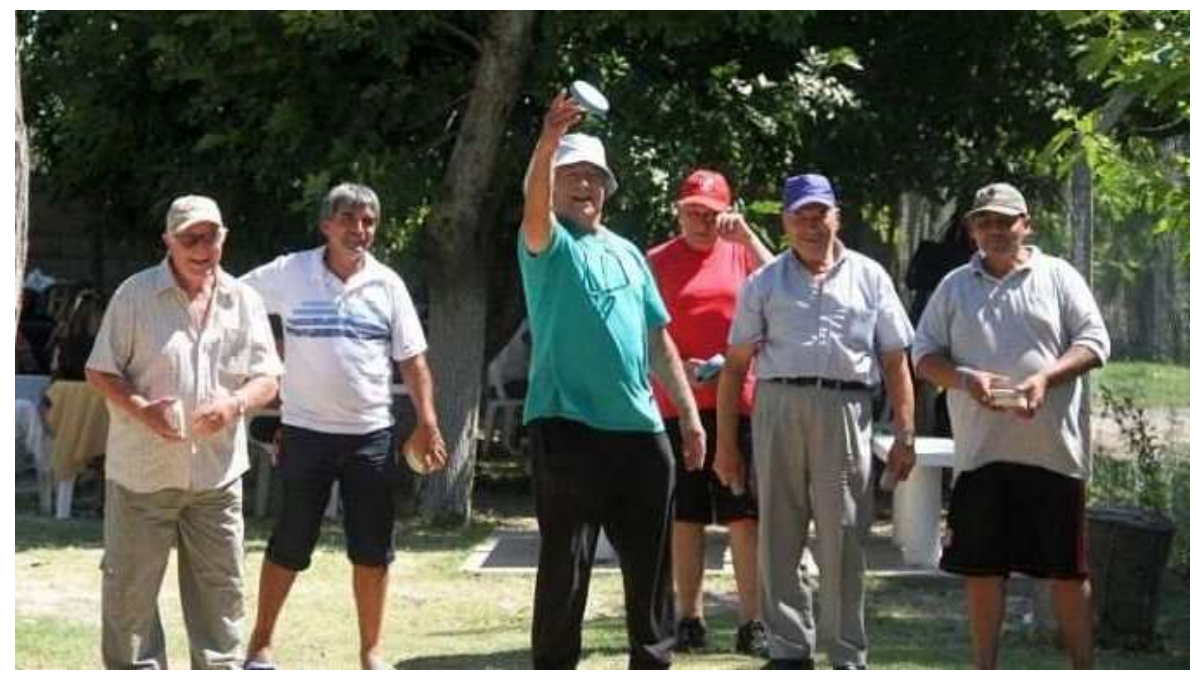

Foto: Archivo de la colonia del verano 2018

Los interesados en inscribirse, deberán acercarse a la oficina de la Tercera Edad, ubicada en $14 \mathbf{N}^{\circ} 1091$ entre 54 y 55, de lunes a viernes de 8 a 16 horas. Allí, se podrá retirar la planilla con la correspondiente ficha de salud que deberá ser completada por el médico de cabecera.

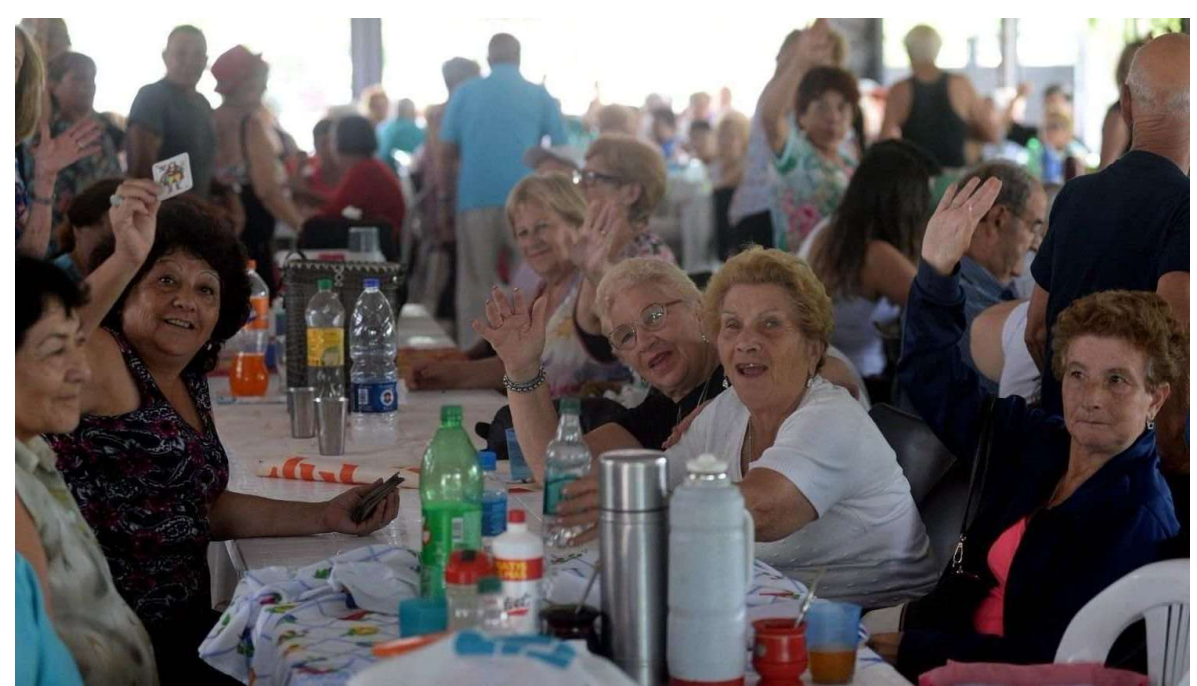


Foto: Archivo de la colonia del verano 2018

Asimismo, para aquellas personas que deseen recibir más información o consultar otras inquietudes, podrán hacerlo vía teléfono al 489-6493.

Al respecto, el subsecretario de Fortalecimiento Institucional, Hugo Béssolo, señaló que "llega otra edición de la colonia para adultos mayores, que contará con nuevas actividades y propuestas, coordinadas por un grupo de 15 profesores".

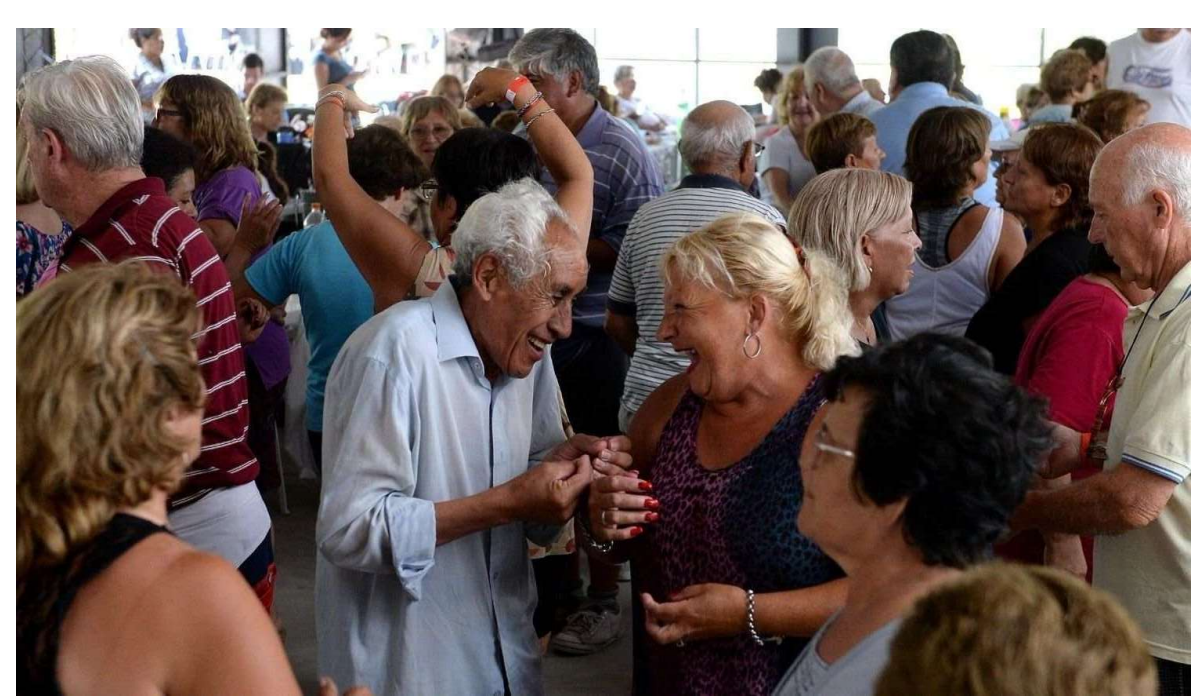

Foto: Archivo de la colonia del verano 2018

"Nuevamente contaremos con el servicio de traslado gratuito para que abuelos de distintas delegaciones de la ciudad tengan la posibilidad de asistir y participar de la Colonia de la Tercera Edad", valoró el funcionario. 


\section{Verano 2019}

\section{Intensifican el despliegue de seguridad por la temporada alta en}

\section{Punta Lara}

Enero 3, 2019 | El Cuerpo de Guardavidas brinda atención todos los días de la semana de 8 a 20 horas en cada uno de los paradores que se extienden en los 14 kilómetros de costa. También hay control vehicular en los principales accesos.

Escrito por ANDigital

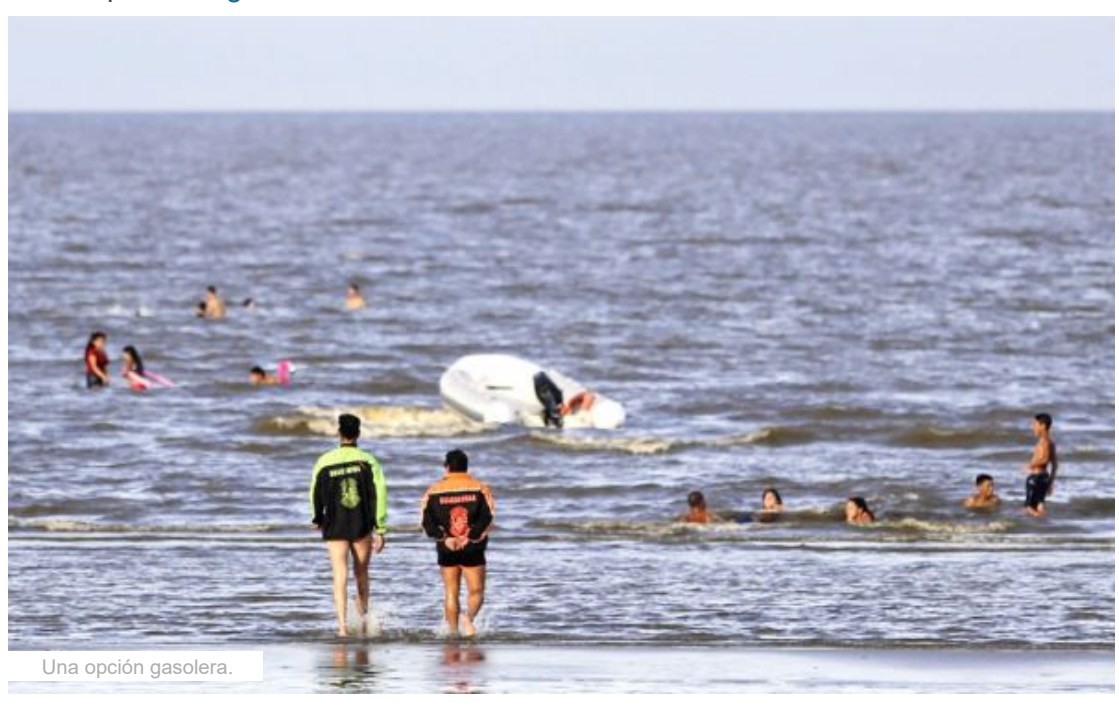

ENSENADA-BUENOS AIRES (ANDigital) Punta Lara recibe a miles de turistas durante la temporada veraniega y desde el municipio se trabaja fuertemente en brindarles seguridad "a todos y cada uno de los vecinos y turistas que eligen la costa ensenadense para vacacionar".

De esta manera, la comuna al mando de Mario Secco pone a disposición el Cuerpo de Guardavidas que brinda atención todos los días de la semana de 8 a 20 horas en cada uno de los paradores que se extienden en los 14 kilómetros de costa.

Cabe mencionar que el equipo está compuesto por 46 profesionales que han sido seleccionados a través de un riguroso examen de admisión.

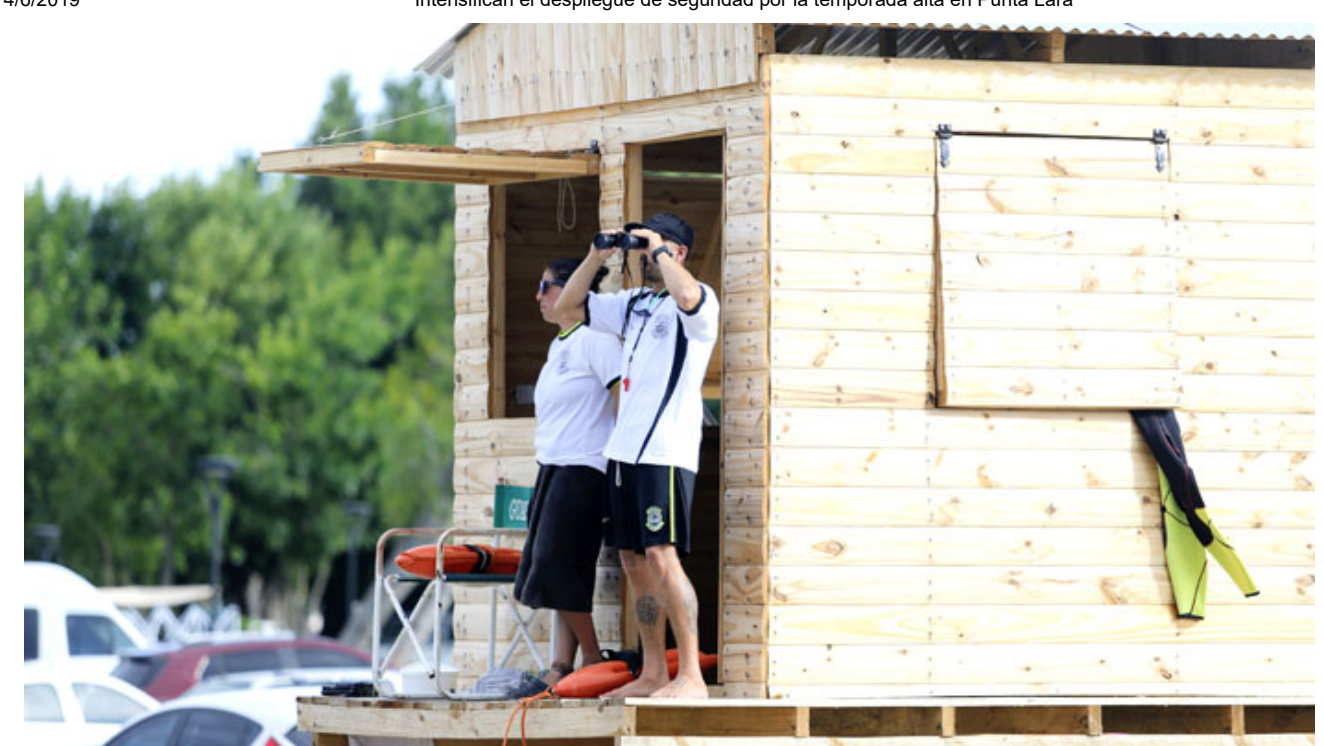

Además, el municipio pone a disposición numerosos vehículos y elementos de trabajo para un mejor accionar de los guardavidas como: camionetas, motos de agua, lanchas, canoas, gomones, chalecos salvavidas, silla anfibia para posibilitar el disfrute del agua para personas con discapacidad, botiquín de primeros auxilios, instrumentos de intercomunicación entre el personal; entre otros.

Vale recordar que, se deben respetar las indicaciones que los guardianes del río realizan con banderines a la vera de la playa. Además de los llamados de atención cuando se traspasa el límite permitido de nado en río o en zonas no permitidas como las de pesca.

El operativo de seguridad en playas además incluye el control vehicular en los principales accesos a Punta Lara; patrullajes con móviles policiales y a pie sobre la playa; el servicio de emergencias médicas a disposición ante cualquier inconveniente y, el cuerpo de guardavidas municipal que custodia las aguas puntalarenses. (ANDigital) 
EDITOR PLATENSE » LA PLATA 17 FEB 2019

\section{Punta Lara está a full con} playas y espacios públicos amplios

Recorrimos el balneario local que se llenó de familias y grupos de amigos en un día a pleno sol. El camino hacia la costa -diagonal 74- muy transitado

\section{PRECIO DEL}

DOLAR

VENTA: $\$ 44,92$

COMPRA: $\$ 42,50$

PARALELO: \$46 EN LA

VER RESULTADOS

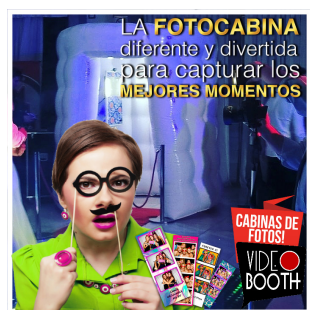

NEWSLETTER

Suscribase a nuestro

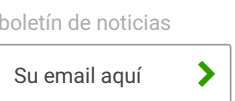

Su email aq

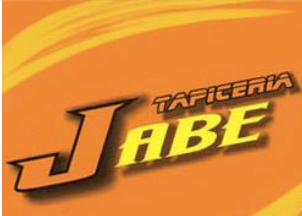

Calle 144 e/ 66 y 77 - Los Homos

VIDEOS
Punta Lara está cada vez más linda. Este verano los vecinos Por: Alejandro de la Región tienen el orgullo de contar con un balneario en e

Salamone río más ancho del mundo para disfrutar a pleno. Desde la rotonda de llegada por el Cno costanero Almirante Brown hacia el lado del centro de Ensenada y el Club de Pesca, la Municipalidad que conduce Mario Secco ha ganado importantes espacios que antes eran ocupados por distintos campings y concesiones privadas que ofrecían poco, y ahora están abiertos a todo el mundo, con instalaciones flamantes como baños públicos, parrillas, mesas, sillas y

estacionamiento libre frente a la playa. Por eso no es llamativo que un día como el de hoy con sol a pleno, se acerquen miles de familias, grupos de amigos, y amantes de los deportes de agua.

Hacia el lado de Boca Cerrada donde sí hay reconocidos camping, como el del Sindicato de Empleados de Comercio que tan bien cuidó siempre Walter Bueno, el Municipio ensenadense también encaró trabajos para mejorar las playas, ganar espacios y construir mobiliario para la comodidad de los visitantes. Este año, señaló una fuente de la Comuna, se intensificaron los controles de alcoholemia y viales en los accesos al balneario, como la proyección de diagonal 74, en cuyos márgenes también llegan miles de familias y se instantan con termos, mates, reposeras y mesitas.

Esta mañana cuando todavía no había llegado el grueso de los visitantes, la playas estaban enormes y el paisaje no tenía nada que envidiarle a ningún otro costanero, incluso de los que bordean el mar.

Punta Lara siempre fue popular. Llegan micros de todos los puntos de la Provincia de Buenos Aires y permite a miles de familias que por recursos económicos no pueden irse de vacaciones al mar, poder disfrutar el Rio de la Plata, de sus playas, y de una costa que hoy se luce muy cuidada.

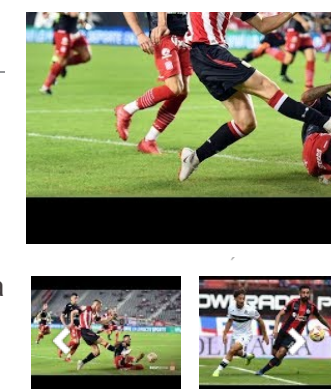

ROOMS

Calle 45 entre 7 y 